УНИВЕРЗИТЕТ У БЕОГРААУ

ФИ^ОЗОФСКИ ФАКУЛТЕТ

Василиос Хронопулос

БАЛКАНСКА ПОЛИТИКА ИЗБЕГАИЧКЕ

ГРЧКЕ ВАAАE

1941-1944. ГОАИНЕ

АОКТОРСКА АИСЕРТАЦИЈА

БеограА, 2010 
UNIVERSITY OF BELGRADE

FACULTY OF PHILOSOPHY

Vasileios Chronopoulos

\section{BALKAN POLITICS OF THE GREEK GOVERNMENTS IN EXILE \\ DURING 1941-1944}

Doctoral Dissertation

Belgrade, 2010 
Састав Комисије за одбрану докторске дисертације је:

dr Milan Ristović, redovni profesor

Odeljenje za istoriju Filozofskog fakulteta

(mentor)

dr Miroslav Jovanović, vanredni profesor

Odeljenje za istoriju Filozofskog fakulteta

dr Milan Terzić, naučni savetnik, Centar za strateške studije, Beograd 
EXECUTIVE SUMMARY (PEЗИME) ...................................

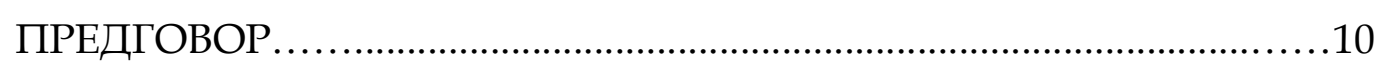

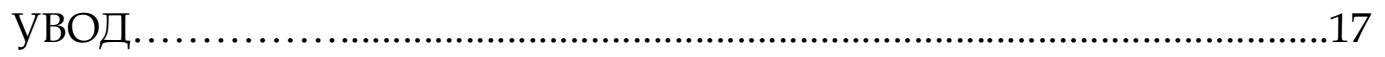

\section{$\underline{\text { ПРВИ ДЕО }}$}

ПРВО ПОГЛАВЉЕ

ИЗБИЈАҢЕ ДРУГОГ СВЕТСКОГ РАТА И ПУТ ГРЧКЕ ВЛАДЕ У ИЗБЕГЛИШТВО

1.1 ИЗБИЈАҢЕ ДРУГОГ СВЕТСКОГ РАТА..............................................26

1.2 ГРЧКА У ТОКУ ДРУГОГ СВЕТСКОГ РАТА.....................................29

1.3 ИЗБЕГЛИЧКЕ ВЛАДЕ У ЕВРОПИ......................................................35

1.4 МЕБУНАРОДНО-ПРАВНИ РЕЖИМ ИЗБЕГЛИЧКИХ

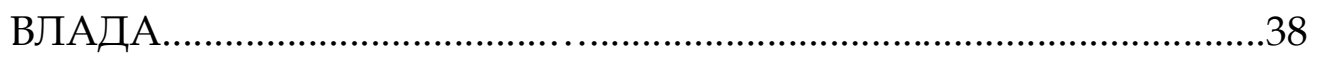

1.5 СЛАБО ФУНКЦИОНИСАҢЕ ИЗБЕГЛИЧКЕ ГРЧКЕ ВЛАДЕ

КАО РЕЗУЛТАТ ЗАВИСНОСТИ ОД ВЕЛИКЕ БРИТАНИЈЕ........42

\section{ДРУГИ ДЕО \\ ДРУГО ПОГЛАВЉЕ \\ НАЦИОНАЛНО-ТЕРИТОРИЈАЛНЕ ПРЕТЕНЗИЈЕ ИЗБЕГЛИЧКЕ ГРЧКЕ ВЛАДЕ}

2.1 НАЦИОНАЛНО-ТЕРИТОРИЈАЛНЕ ПРЕТЕНЗИЈЕ

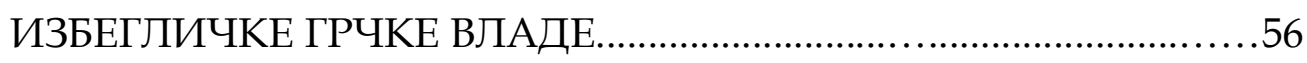

2.2 УКАЗ О ГРЧКИМ НАЦИОНАЛНИМ ПРЕТЕНЗИЈАМА............59

2.3 ИЗЛАГАЮЕ ГРЧКИХ ПРЕТЕНЗИЈА ВЛАДАМА САД И 
ВЕЛИКЕ БРИТАНИЈЕ. .65

2.4 РАСПРАВЕ О ГРЧКИМ НАЦИОНАЛНИМ

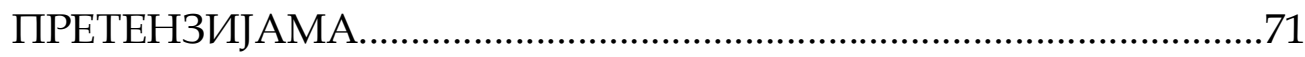

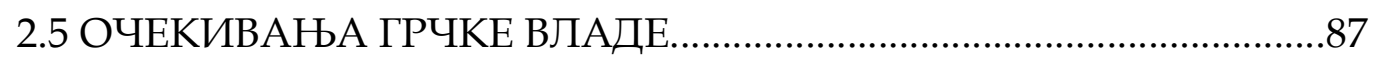

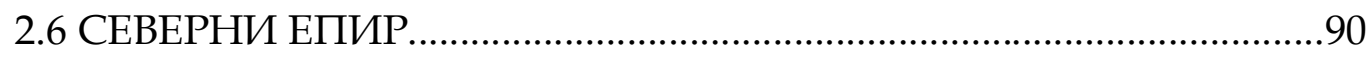

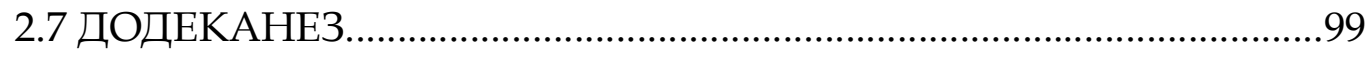

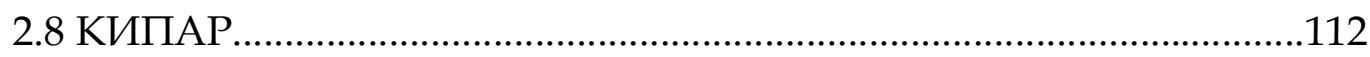

\section{ТРЕЋИ ДЕО}

\section{ТРЕЋЕ ПОГЛАВЉЕ}

БАЛКАНСКА ПОЛИТИКА

ИЗБЕГЛИЧКЕ ГРЧКЕ ВЛАДЕ

3.1 ОКУПИРАНИ БАЛКАН И ПОЛИТИКА БАЛКАНСКИХ

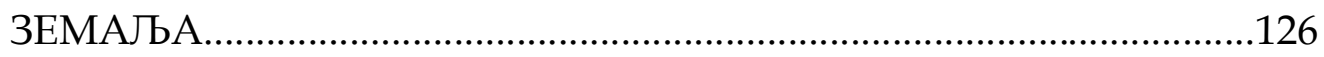

3.2 ГРЧКО-ЈУГОСЛОВЕНСКИ ОДНОСИ...............................................130

3.2.1 РАЗМИШЉАҢА И ОДЛУКА ГРЧКЕ ВЛАДЕ ДА СТАВИ

ПОТПИС НА ГРЧКО-ЈУГОСЛОВЕНСКИ СПОРАЗУМ............130

3.2.2 ГРЧКО-ЈУГОСЛОВЕНСКИ СПОРАЗУМ ОД 15. ЈАНУАРА

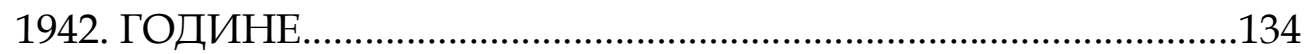

3.2.3 ПРОЦЕНА ГРЧКЕ ВЛАДЕ У ВЕЗИ СА ПОТПИСИВАҢЕМ

ГРЧКО-ЈУГОСЛОВЕНСКОГ СПОРАЗУМА....................................144

З.3 ГРЧКО-БУГАРСКИ ОДНОСИ............................................................150

3.3.1 ПОЛИТИКА ГРЧКЕ ЕМИГРАНТСКЕ ВЛАДЕ ПРЕМА

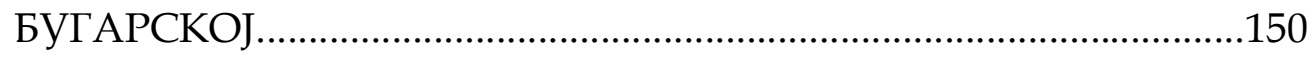

3.3.2 МИРОВНИ СПОРАЗУМ САВЕЗНИКА СА БУГАРСКОМ И

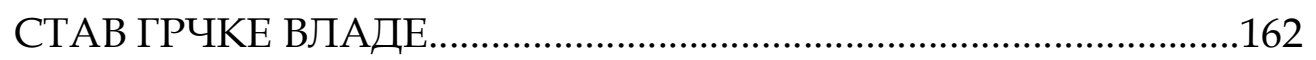

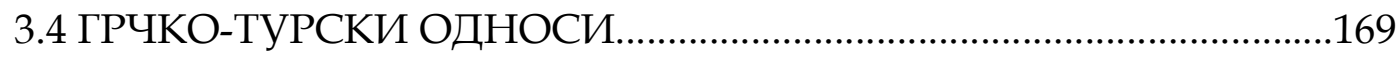

3.4.1 ГРЧКО - ТУРСКИ ОДНОСИ У ДРУГОМ СВЕТСКОМ

PATY. 
3.4.2 ТУРСКИ СТАВ ПРЕМА ГРЧКОЈ МАҢИНИ И ПОРЕЗ

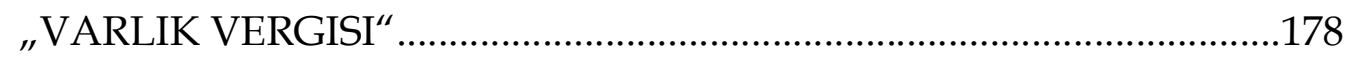

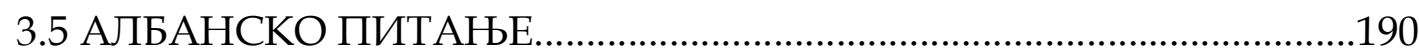

3.6 РУМУНИЈА У ПОЛИТИЦИ ГРЧКЕ ВЛАДЕ У

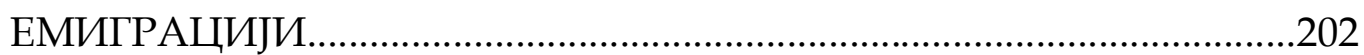

\section{ЧЕТВРТИ ДЕО}

ЧЕТВРТО ПОГЛАВЉЕ

СИТУАЦИЈА НА БАЛКАНУ ПОСЛЕ ДРУГОГ СВЕТСКОГ РАТА И ПОВРАТАК ИЗБЕГЛИЧКЕ ГРЧКЕ ВЛАДЕ

4.1 ДИПЛОМАТИЈА ТРИЈУ ВЕЛИКИХ СИЛА.........................209

4.2 ЦУДЕРОСОВО ГЛЕДИШТЕ О ПОЛИТИЧКОМ СИСТЕМУ

ГРЧКЕ ПОСЛЕ ДРУГОГ СВЕТСКОГ РАТА....................................218

4.3 ПОВРАТАК ГРЧКЕ ЕМИГРАНТСКЕ ВЛАДЕ И УРЕЪЕЊЕ

ПОЛИТИЧКОГ СИСТЕМА - ПРОБЛЕМ ОДНОСА СА

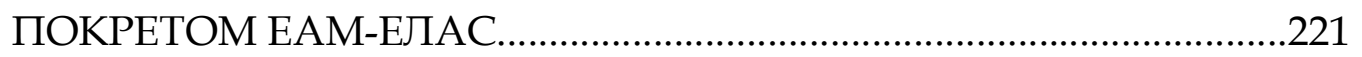

4.4 СИТУАЦИЈА НА БАЛКАНУ КРАЈЕМ И ПОСЛЕ ЗАВРШЕТКА

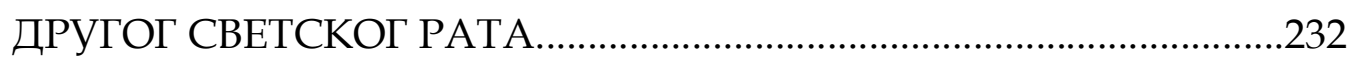

4.5 ПРИБЛЕМИ И РЕЗУЛТАТИ ГРЧКИХ НАЦИОНАЛНИХ

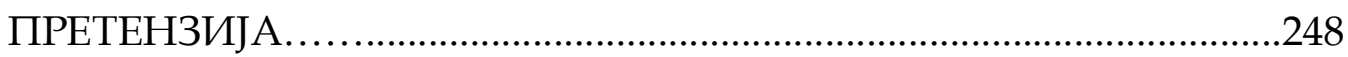

ЗАКЉУЧАК........................................................256

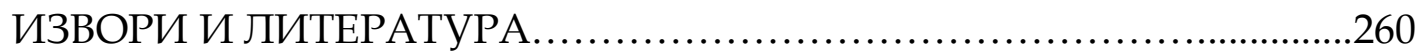

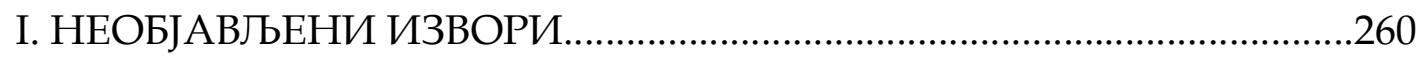

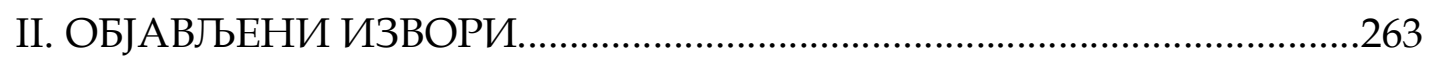

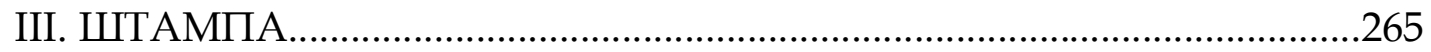

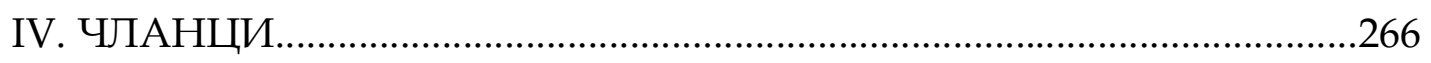

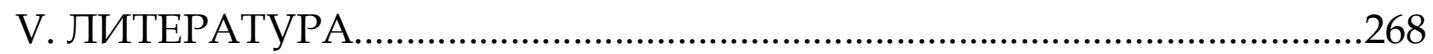




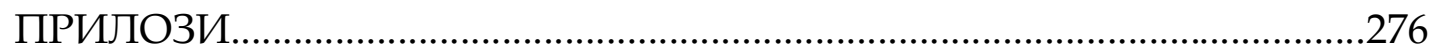

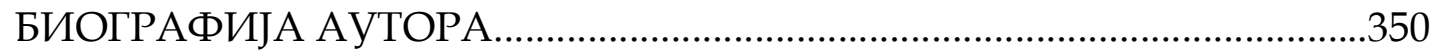




\section{EXECUTIVE SUMMARY}

The aim of this dissertation is the description and analysis of Greek Balkan politics during 1941-1944. The activity of the Greek government in exile creates some practical issues with respect to the way of exerting politics. In addition, the independence of the Greek Balkan politics is investigated, as well as the presence of a particular strategy in it. Furthermore, the national claims that Greek Balkan politics presented in front of their allies in the conference of Peace in Paris are presented, along with the fundamental ideas of these claims and to what extend the Greek national claims were fulfilled. Moreover, this dissertation refers to the politics that was implemented against the rest of the Balkan countries, the existing circumstances in Greece during the return of the exile government and the thoughts about the future of the political system in Greece.

The project was carried out based upon published archived material of the Greek and Serbian Ministry of Foreign Affairs, the Historical Archive of Serbia and Montenegro (Yugoslavia) and General State Archives of Greece. Along with these, material from the Academy of Athens (Research Center for the Study of Modern Greek History) and the British Ministry of Foreign Affairs (Foreign Office 371) was utilized. Finally, I used material from the

National Library of Serbia, Library of the Philosophical University of Belgrade, National Library of Athens, Gennadius Library and Library of Panteion University. 


\section{РЕЗИМЕ}

Циљ истраживања, у оквиру докторске дисертације „Балканска политика Грчке владе у емиграцији 1941-1944. године“, је да сагледа и анализира балканску политику грчке емигрантске владе током Другог светског рата. Влада у условима избеглиштва је морала да се суочи са многоструким практичним питањима у вези са доношењем одлука и начинима утврђивања политике. Детаљније ће бити испитано у којој мери је балканска политика грчке емигрантске владе била самосвесна, да ли је имала неку јаснију концепцију балканске политике, које су биле националне и територијалне претензије Грчке и које су биле основе тих претензија, каква је била политика Грчке према другим балканским земаља, каква је била ситуација у земљи после повратка емигрантске владе у Грчку, каква су била мишљења о уређењу политичког система и да ли су на крају остварене грчке националне претензије.

Рад је урађен на основу необјављеног архивског материјала, већег броја архивских фондова архива Министарства спољних послова Србије и Грчке, Архива Србије и Црне Горе (Југославије) и Генералног архива грчке државе. Значајни подаци прикупљени су из Архиве Академије у Атини (Центар за истраживање новије грчке историје) и из документације Министарства спољних послова Велике Британије (Foreign Office 371). Такође, у сврху прикупљаља потребног материјала за рад, радио сам у библиотекама у Србији, конкретно у Библиотеци града Београда, Народној библиотеци Србије и библиотеци Филозофског факултета. Значајан материјал пронашао сам и у одређеним библиотекама у Атини: Народна библиотека Атине, Библиотека Генадиос, Библиотека Грчког парламента и Библиотека Пандио факултета. 


\section{ПРЕДГОВОР}

Рад „Балканска политика Грчке владе у емиграцији 1941-1944. године“ настао је у оквиру докторских студија на Филозофском факултету у Београду, под надзором професора Др Милана Ристовића. Током писања овог рада имао сам пуну подршку особа, које бих желео да наведем. Нарочито бих желео да се захвалим професору Милану Ристовићу, који ми је својим саветима у великој мери помогао да поменути рад приведем крају. Такође, додао бих да је наша сарадња била изузетна и врло пријатељска. Желео бих такође да се захвалим Марку Поповићу, који је преводом текста такође допринео остваривању рада.

Грчка је 6. априла 1941. године постала жртва напада удружених снага Осовине. Њена територија је била подељена, стављена под неколико различитих окупационих управа или била анектирана. Влада и Краљ, са делом војске су се повукли из земље пред непријатељским нападом и ратне године 1941-1944 провели су у избеглиштву, у Лондону и Каиру.

Избегличке владе представљају специфичнан наставак државног континуитета, феномен који се јавља након почетка Другог светског рата, због агресије и војне окупације великог дела Европе од стране сила Осовине. Ове владе, и поред тога што су биле великим делом изоловане, без сталних и поузданих конатаката са домовином, и без већег утицаја на политичка збивања на територијама њихових држава, одликовале су се, свака појединачно, разноврсним карактеристикама и специфичностима, да би их чак било погрешно сврстати у исту групу и према истим критеријумима, нарочито по питању њиховог стварног утицаја и легитимитета. Неке су биле законски изабране, неке су представљале шири „спектар“ политичких снага својих земаља, док су друге просто биле постављене. Све су, међутим, биле савезничке и као такве биле су 
фактори међународних односа и дале су, свака у границама својих могућности, прилог заједничком ратном напору .

Ограничена способност деловања избегличке владе Грчке била је последица колико стране окупације земље, толико и већ постојећих унутрашњих проблема, као што су били сиромаштво и обнављање политичких снага током међуратног периода које није уродило плодом, непрестани преврати, интервенције војске, продужење раскола и недостатак легитимитета изабране владе, и то у тренутку када је Грчка већ ушла у Други светски рат. Функционисање земље у условима избеглиштва, поред уставних и проблема око Међународног права, отежавала су и многострука практична питања у вези са доношењем одлука, начинима утврђивања политике и њеним последицама. Поврх свега, влада у избеглиштву недостатке у свом саставу и деловању дугује и страном мешању у грчка питања. Током Првог светског рата постојао је снажан страни утицај на политички живот Грчке, који се завршио расколом.

За време Другог светског рата контролу над Грчком владом имала је у потпуности само једна држава - Велика Британија. Специфичне су и друге чињенице, као нпр. неједнака посвећеност избегличких влада сарадњи са савезницима, немогућност успостављања доследне и дугорочне спољне политике, неозбиљно суочавање са потенцијалном моћи њихових сународника из дијаспоре, нарочито у САД-у, као и политика Грчке у послератном периоду за коју нису биле карактеристичне иницијативе већ супротстављање истим. Један такав пример било је и приближавање Грчке Југославији на иницијативу Британије, ради остваривања плана балканског уједињења (1942), са циљем спречавања продора утицаја Совјетског Савеза на Балканско полуострво. Међутим, муњевито погоршање веза Истока и Запада, после 1945. године, укључујући и грађански рат у Грчкој, учинили су овај план неостварљивим. 
Циљ предложеног истраживања, у оквиру докторске дисертације, је да сагледа и анализира балканску политику грчке емигрантске владе током Другог светског рата. Влада у условима избеглиштва је морала да се суочи са многоструким практичним питањима у вези са доношењем одлука и начинима утврђивања политике. Детаљније ћемо испитати у којој мери је балканска политика грчке емигрантске владе била самосвесна, да ли је имала неку јаснију концепцију балканске политике, које су биле националне и територијалне претензије, и које су биле основе тих претензија, каква је била политика Грчке према другим балканским земаља, каква је била ситуација у земљи после повратка емигрантске владе у Грчку, каква су била мишљења о уређењу политичког система и да ли су коначно остварене грчке националне претензије.

Рад ће бити подељен на четири поглавља. У првом поглављу, под насловом „Избијање другог светског рата и пут грчке владе у избеглиштво“, говорићемо о избијању Другог светског рата и о условима који су том приликом настали у Европи. Такође, навешћемо пут Грчке владе током Другог светског рата. Доминација сила Осовине приморала је владе многих европских земаља да напусте своја седишта и да пребегну, углавном у Велику Британију. Паралелно са избегличким владама европских земаља, биће испитан и њихов међународно-правни положај. Затим, биће речи о проблемима са којима се суочавала Грчка влада током њеног избеглиштва у Лондону. Ови проблеми били су последица постојеће ситуације и њених промена током рата. Строга контрола Британаца, наметнута Грчкој, као и осталим избегличким владама, битно је сужавала простор за деловање што није дозвољавало независнији рад грчке избегличке владе.

У другом поглављу рада, под називом „Националнотериторијалне претензије избегличке грчке владе“, бавићемо се покушајима дефинисања и постављања претензија грчке емигрантске владе које је требало после рата реализовати. Ове претензије су 
првенствено биле везане за територијална потраживања према суседним државама, посебно онима где постоји грчко становништво, као што је био случај са Северним Епиром, Додеканезом и Кипром. У наставку ће следити посебно поглавље за сваки од ових захтева. Детаљније ћемо говорити о проблему Северног Епира, Додеканеза, о кипарском проблему и о начину на који је грчка емигрантска влада покушавала да дође до анектирања ових територија, (Северног Епира од Албаније, Додеканеза од Италије и Кипра од Британије). Председник Грчке владе у избеглиштву Емануил Цудерос је истицао, да кад Грци говоре о поменутим захтевима, не мисле на неку промену граница, јер верују да ове територије «природно припадају» њима. Такође, бавићемо се анализом различитих ставова о овим захтевима, проблемом организовања и координације покушаја за њихово остваривање, и очекивањима грчке емигрантске владе.

У трећем поглављу, „Балканска политика избегличке грчке владе“, након детаљног описа политичке ситуације на Балкану током Другог светског рата, анализираћемо балканску политику грчке емигрантске владе. Више детаља о томе биће посвећено у поглављима о односима са сваком балканском државом посебно. Грчка емигрантска влада је са југословенском емигрантском владом у Лондону, потписала Споразум о стварању федерације, 15. јануара 1942. године, на иницијативу Велике Британије. Такође, биће реч о промени граница са Југославијом коју је захтевала грчка страна због осигуравања својих граница.

Логичнији је био захтев грчке емигрантске владе за промену граница са Бугарском, пошто је сматрала да треба предузети све мере које ће осигурати да Бугарска не може убудуће да угрожава суседне државе. Председник грчке емигрантске владе Цудерос, сматрао је да је предлог Бугарске за стварање независне Македоније опасан и да би требало да се на сваки начин избегне. Слично је мислио и остваривању проширене југословенске федерације, која би укључила и Бугарску, и нарушила равнотежу на Балкану. 
У односима са Турском сматрало се да, уколико она буде против Савезника, Грчка влада би тражила источну Тракију и признавање Цариграда као независне државе, уз учешће Грчке у њеној администрацији и контроли над Босфором. Што се тиче питања односа са Албанијом, Грчка влада је изашла са захтевом за Северни Епир. Односи са Румунијом су били од другоразредног значаја, јер између две државе није било се није било озбиљних спорних питања, осим питања положаја Влаха који су живели у Грчкој.

У четвртом поглављу, „Ситуација на Балкану после Другог светског рата и повратак избегличке грчке владе“, говорићемо о ситуацији на Балканском полуострву, која се променила на крају и непосредно после Другог светског рата, као и о политици сваке балканске државе посебно. Након тога, следи детаљан опис повратка грчке емигрантске владе и проблему уређења политичког система у Грчкој. Значајно је какав је био став народноослободилачких покрета отпора према влади и шта су ти покрети, политичке партије и значајне личности мислили о уређењу политичког система. У наставку испитаћемо ток и исход грчких националних претензија, и у којој мери су били испуњени на Конференцији мира у Паризу. Коначно, као епилог, испитаћемо дипломатију трију великих сила - Велике Британије, Сјединих Америчких Држава и Совјетског Савеза према Грчкој.

Тема којом се бави ова докторске дисертације до сада није детаљније истраживана ни у грчкој историографији, ни у другим историографијама, и због тога не постоји монографски рад посвећен овој теми, нити нека обимнија литература која се бави овом тематиком. Тема је урађена на основу истраживања необјављеног архивског материјала, већег броја архивских фондова у архивима у Србији и Грчкој и историографске литературе о емигрантској влади Грчке и Другом светском рату.

Значајни подаци прикупљени су у Архиву Србије и Црне Горе (Југославије), у Архиву Министарства спољних послова Грчке, у 
Генералном архиву грчке државе, у Војном архиву Београда, из грађе Академије у Атини (Центар за истраживање новије грчке историје) и из документације Министарства спољних послова Велике Британије (Foreign Office 371). Детаљније, у Архиву Србије и Црне Горе (Југославије) прегледао сам следеће архивске фондове: 103 Емигрантска Влада К.J. 1941-1945, 370 Посланство К.J. у Турској - Цариград, Анкара 1919-1945, 411 Генерални Конзулат К.J. у Цариграду.

У Архиву Министарства спољних послова Грчке: А' Полєєєиं,

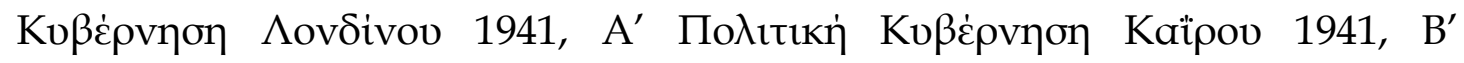

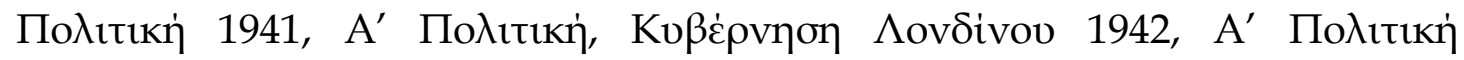

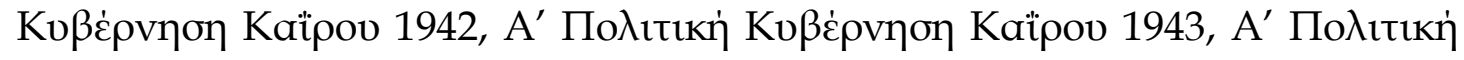

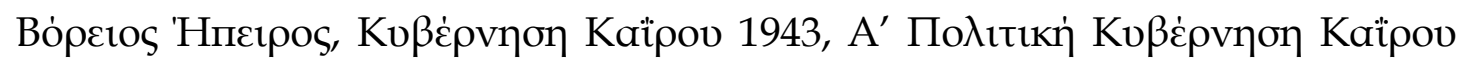

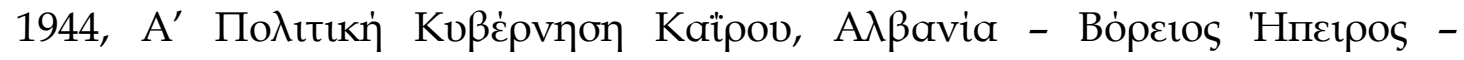
$\Delta \omega \delta \varepsilon \kappa \alpha \dot{v \eta} \sigma a$ 1944. Такође, значајни необјављени материјал сам прикупио из Архива Цудероса који се налази у Генералном архиву грчке државе у Атини, необјављени документи из архива, као и из дневника Цудероса, који се чувају у библиотеци Генадиос у Атини.

Да бих прикупио потребан материјал за рад, радио сам у библиотекама у Србији, конкретно у Библиотеци града Београда, Народној библиотеци Србије и библиотеци Филозофског факултета. Значајан материјал пронашао сам и у одређеним библиотекама у Атини: Народна библиотека Атине, Библиотека Генадиос, Библиотека Грчког парламента и Библиотека Пандио факултета.

Основни методолошки приступ биће заснован на раду са необјављеним материјалом, различитог порекла (југословенска, грчка, британска), која је настала пре свега из делатности дипломатских и других тела влада Грчке, Југославије и Велике Британије. То је класичан историографски метод, који намеће сама природа теме. Посебан приступ нуде аутобиографски извори (мемоари и дневници), који дају једну личну димензију политичких догађаја. 
Избегличке владе представљају специфичнан наставак државног континуитета, који постаје неопходан нарочито након почетка Другог светског рата, због војне окупације великог дела Европе од стране сила Осовине. Студије о политици ових влада, која се изражавала кроз постојеће суштинске слабости, и која је у зависности од случаја показивала или енергичност или потпуну инертност у свом деловању, постоје у фрагментима. Што се тиче Грчке, малобројне студије спољне политике које покривају период Другог светског рата, садрже по правилу анализе и процене билатералне природе. Оне испитују везе, углавном са Великом Британијом, САД-ом, СССР-ом и, у мањој мери, са суседним балканским државама. У историографији, тренутно, не постоји пуно радова који су се на одговарајући начин бавили балканском политиком грчке емигрантске владе. Предложена дисертација представља покушај да се истражи детаљније политика Грчке владе у емиграцији према другим балканским земаља, њени циљеви, њене националне претензије и резултати тих претензија. Заносвана на материјалу различитог порекла, ова дисертација требало би да пружи и једну сложенију слику збивања на Балкану и односа међу балканским државама током Другог светског рата. 


\section{УВОД \\ ОДНОСИ ИЗМЕЪУ БАЛКАНСКИХ ЗЕМАЉА У МЕЂУРАТНОМ ПЕРИОДУ}

Познато је да је завршетом Првог Светског рата званична спољна политика Грчке обележена напуштањем такозване Велике идеје и вере у нови систем заједничке безбедности за коју се претпостављало да ће осигурати Лига народа. Прича о њој је веома брзо почела да бледи са појављивањем Бенита Мусолинија на међународној сцени. Окупација Крфа од стране Италијана, 31. августа 1923. године, је доказала да би учешће једне велике силе у било ком конфликту учинило неприменљивим механизме ове организације.

Вера Грчке у тај нови систем заједничке безбедности је грубо срушена италијанском окупацијом Крфа. Грчка у том тренутку није имала пуно избора на располагању. Њен дипломатски став на међународној сцени је био у незавидном положају. Италија ју је била изазвала, Велика Британија није показала расположење да даје било какве гаранције, а Француска је усмерила своју пажњу на Централну Европу, играјући улогу „велике силе“ у овој осетљивој области. Остао је Балкан, традиционално узбуркан простор, који није пролазио кроз свој најбољи период, бар гледајући на ствари из грчке перспективе.

Пре свега је постојао проблем Бугарске, која никада није прихватила услове Мировног уговора. Било је очигледно да је ова чињеница представљала непремостиву препреку да се реше разлике између две земље, као што су питање територијалног излаза на Егејско море, економске разлике које је изазвала обострана сеоба становништва итд. Незадовољсво обе стране се манифестовало инцидентом на грчко- 
бугарској граници 1925. године, због кога је Лига Народа увела санкције Грчкој ${ }^{1}$.

Што се тиче Југославије, ни тамо није била боља ситуација. Ова земља је веровала у status quo Уговора о миру из најпростијег разлога што је Србија припадала групи победника из претходних ратова. Значајна територијална експанзија Југославије, као и подршка Француске, су јој дали могућност да, као локална „велика сила“, повећа своје захтеве према слабашној Грчкој². Тачније, тражила је посебни споразум за заштиту мањина, признавање „слободне зоне“ Солуна, као своје територије и контролу над железничком линијом Ђевђелија Солун ${ }^{3}$.

Грчка није могла ни са Турском да нормализује своје односе, и поред чињенице да је прихватила потпуни губитак Мале Азије. У томе су је спречавале неспоразуми у решавању питања процене имовине размењеног становништва, као што је одређивао Споразум у Лозани. Специјална мешовита комисија која се бавила овом тематиком није могла да функционише продуктивно због велике разлике у мишљењима обе стране, са исходом да се проблем одуговлачи. Поред овога, Турска је показивала провокативно понашање према Васељенском Партијарху и грчком становништву Константинопоља, чињеница због које је расло грчко неповерење 4 .

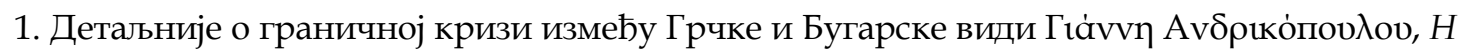

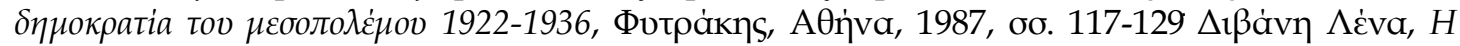

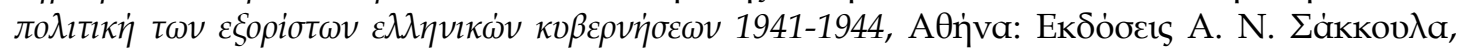

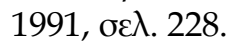

2. У вези са Југославијом и њеном спољном политиком погледај поглавље «уггославија» у књизи Антонија Полонског, The Litle Dictators, The History of Eastern Europe since 1918, Routledge and Kegan Paul, London, 1975, oo. 94-106.

3. Југословенска влада се успротивила и због прилога протокола Политис - Калоф зато јер је оповргавао њена мишљења о националном карактеру становника југословенске Македоније. Такође је тражила повраћај одузете земље Манастира Хиландара (К.

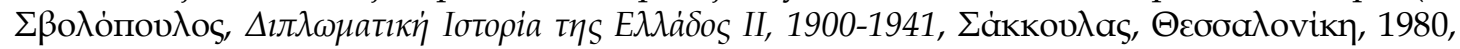
бо. 178-179).

4. О грчко-турским проблемима и последицама које су имали на грчкој заједници и Патријаршији види Alexis Alexandris, The Greek Minority in Istanbul and the Greek-Turkish relations 1918-1974, Athens, 1983, oo. 1-210. 
Грчку је са Албанијом раздвајало питање одређивања међусобних граница и, пре свега, огорчење због непоштовања било ког права грчког становништва у Северном Епиру5. Добри односи су постојали између Грчке и Румуније, али ништа више од тога. С друге стране једна кап доброг расположења није могла много тога да учини у мору неповерења који је преплављивао Балкан.

У временском периоду од скоро десет година након завршетка Првог Светског рата, и поред пропагирања врлина локалних заједничких савезника ${ }^{6}$, било је јасно да ситуација у региону није била позитивна, узевши у обзир да је конкуренција великих сила у овој области повећавала, већ постојеће, тензије међу државама. Снаге које су у овој првој послератној деценији учиниле неке динамичне интервенције на Балканском Полуострву, биле су фашистичка Италија, која је контролисала Албанију и Бугарску, и Француска која је утицала на Југославију и Румунију.

Формулисана је теорија да на Балкану постоје две основне групације: грчко-турска и словенска, која обухвата Југословене и Бугаре. Веровало се да постоји реална шанса за балканске интеграције, с тим што прво треба да се приступи свакој земљи појединачно, затим да пређу у фазу међусобног уједињавања, и да на крају прихвате у свој фронт неутралну Румунију и Албанију, које се не уклапају ни у једну од две групације7. Међутим, познато је да везе између Грчке и Турске, као и

5. У вези са притисцима које је вршила албанска влада над гчким становништвом Северног Епира, С. Ласкарис говори да су у питању били прогони, који су за последицу имали интервенцију Лиге народа 1934.године. Ово се десило и поред чињенице да је Грчка била међу првим земљама које су признале Ахмета Зога за краља Албаније 1928.

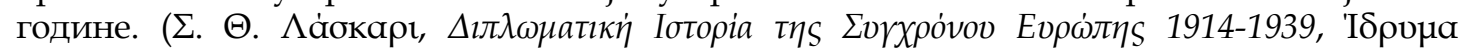

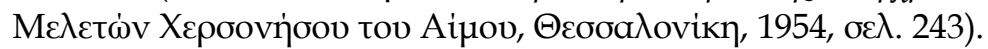

6. Односи се на јако изражену тенденцију за склапање споразума, познатија у међународној терминологији као расtomania, која је владала у послератној Европи. Као резултат тога имамо три споразума: у Луцерну 1925.године, у Паризу 1928.године, и у Женеви исте године, које су имале за циљ мирно разрешавање конфликта. Овим споразумима европски народи су мислили да је мир осигуран (G. Ross, Oı Mcráles

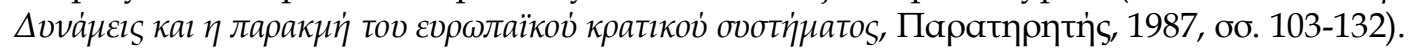

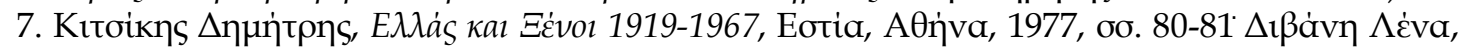

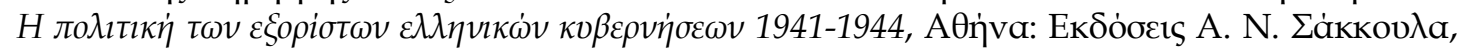
1991, об. 229-230. 
између Југославије и Бугарске, нису биле уопште пријатељске у том периоду. Грчка се није слагала са Турском око расподеле имовине размењеног становништва и у неким мањим стварима, док су југословенске жеље да се помире са Бугарском стагнирале из страха који су имали од ВМРО-а, која је у почетку имала за циљ оснивање аутономне македонске државе. Међутим током времена, под бугарским утицајем, променила је свој циљ у припајање Македоније Бугарској ${ }^{8}$ Чињеница да је деловање BMPO-а, које је било подржавано од стране званичне Бугарске владе, спречавало сваку наду која се тицала споразума између две земље. Ово је представљало велико растерећење за Грке и Турке који су уједињење Словена посматрали као велику претњу.

Тмурни облаци над Балканом су почели да се разилазе тек пред крај 1920-их година, када се и указала повољна прилика за остварење визије уједињења Балкана. У Грчку се 1928. године вратио премијер Елефтериос Венизелос, још снажнији него пре, одлучан да из корена промени дотадашњи положај државе на међународној сцени. Тачније, покушао је да побољша ондосе са претећим суседом Италијом, компромитујући чак и традиционално добре односе Грчке са Великом Британијом, који су били запостављени. Исте године које је био поново изабран на месту премијера, потписао је уговор о пријатељству са Мусолинијем, и на тај начин је аутоматски поправио међународни углед земље.

Грчко-италијански приступ је такође помогао да дијалог између Грчке и Турке пређе на нове основе. Треба истаћи да је Венизелос, као и Кемал, веровао у важност грчко-турског пријатељства. Свакако оба лидера су сматрала савезништво два народа једном врстом оружја против интервенција Великих Сила. Имајући ову замисао, Венизелос је учинио један племенит потез према Турцима, прихватајући један

8. О оснивању ВMPO-а (1893) и о почетним циљевима ове организације види. Е. Kofos, Nationalism and Communism in Macedonia, Thessaloniki, 1964, oo. 25-30. 
економски аранжман на штету Грчке 9 . Овај потез је значио, према речима Исмета Иненија, премијера Турске, „почетак једног новог периода искреног и честитог пријатељства“ и у јуну 1930. године водио је ка потписивању уговора о коначном решењу преосталих питања која проистичу из споразума о размени становништва. У октобру исте године је следило потписивање билатералног споразума о пријатељству, неутралности и арбитраже и 1933. године најважнијег безбедносног пакта, односно одбрамбеног савеза против Бугарске.

Иста позитивна промена је примећена и код грчко-југословенских односа. Грчка је са својим обновљеним ауторитетом убедила Југославију да потпише билатерални протокол у октобру 1928. године о регулисању преосталих разлика између две земље. Оваквом развоју догађаја је помогла и Француска која се надала да ће грчко-југословенски споразум да ублажи зависност Грчке од италијанске политике.

Између Грчке и Румуније у прошлости нису постојали значајнији проблеми. Једноставно су се у том периоду још више учврстиле пријатељске везе, чињеница која је потврђена у августу 1931. године с склапањем билатералног споразума о трговини, бродском саобраћају и емиграцији. Једина негативна ствар у општем развоју догађаја била је непоправљање односа са Албанијом и Бугарском ${ }^{10}$.

Међутим, поред свега овога, Венизелос није имао за циљ балканске интеграције, нити је веровао у једну такву могућност. Као што је и јавно изјавио: „Идеја Балканске Федерације је одлична и радио сам на њој пре рата, али Балкански ратови и Светски рат мислим да не дозвољавају данас реализовање ове идеје, јер су исти ратови раздвојили народе страстима и непријатељствима. Идеју федерације би било боље да

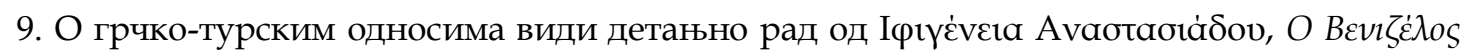

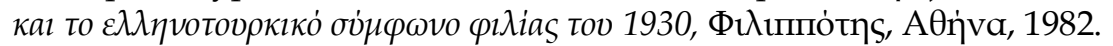

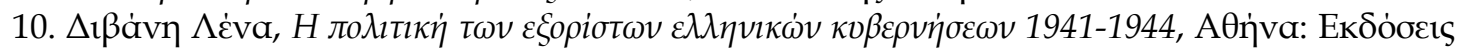

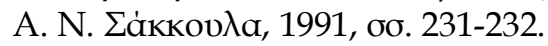


оставимо новим генерацијама на Балкану, а ми с друге стране, да се сконцентришемо на консолидацију мира кроз споразуме“11.

Међутим, постојали су и други фактори који су подржавали идеју интеграције Балкана, упркос Венизелосовом ставу. Први и најважнији фактор је био светска економска криза која је избила 1929. године, чије последице су убрзо погодиле и Балкан, регион који је зависио од своје пољопривредне производње. Грчка, располагајући искључиво са првокласним производима предодређеним за извоз, наишла је на озбиљан проблем и неминовно се окренула протекционизму. Познато је да су и неке друге економије пре Грчке прибегле државном посредовању како би преживеле прве знаке ове кризе. Једно озбиљно решење је било, према општим признањима, стварање економске уније $\mathrm{e}^{12}$. Тада наступа тренутак Александроса Папанастасиуа, визионара балканских интеграција ${ }^{13}$. Он је још 1929. године био формулисао свој предлог, да би следеће године организовао незваничан скуп у Атини с циљем да се испитају могућности балканских интеграција. Венизелосова влада се званично није слагала са организовањем тог скупа, али га није спречила. С друге стране, покушала је да има неку врсту контроле над грчком делегацијом која је учествовала на балканским конференцијама. Предлози грчке групе су обухватали: политички приступ са потписом мултилатералног балканског споразума о ненападању, економски приступ са структуром делимичног царинског уједињења и потписивање споразума о слободи кретања, насељавања и рада у државама Балкана. У вези са слободним насељавањем, треба истаћи да

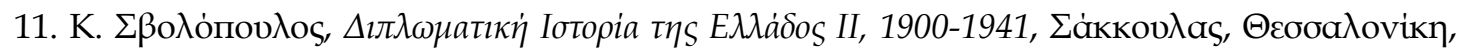

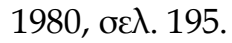

12. О утицају кризе из 1929.године на реализацију идеје о балканском уједињењу види

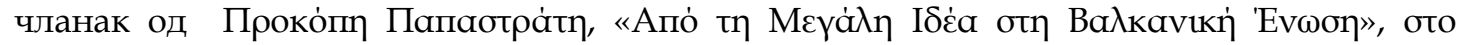

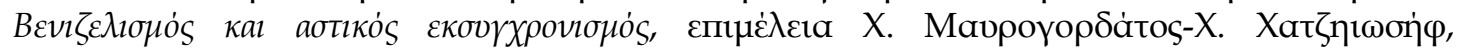

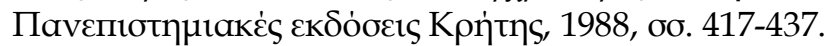

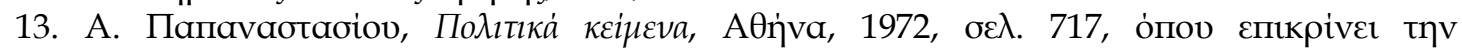

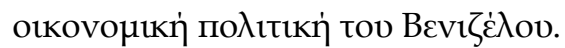


би то решило велики грчки проблем са пребацивањем вишка радне снаге у Турску, као и друге земље ${ }^{14}$.

Организована су четири балканска скупа: 1930. године у Атини, 1931. године у Константинопољу, 1932. године у Букурешту и 1933. године у Солуну. Од органа скупа, најимпресивнији рад је представила „Комисија за економска питања“, која је дошла до закључка да би највећим процентом балканских производа могло да се располаже унутар Балканског полуострва, док је до тада балканско тржиште представљало само 9\% од свег страног тржишта сличних земаља ${ }^{15}$. Грчка би имала проблем уколико покуша да оствари једну такву економску политику зато што је тешко да се њени производи продају као луксузни или јаднаки са другим балканским земљама. Међутим, имајући једну релативно развијену индустрију могла би да промовише своје индустријске производе на балканском тржишту у замену за пољопривредне ${ }^{16}$.

У политичким оквирима, балкански скупови нису забележили велике успехе. Препрека за то је поново била Бугарска која је агресивно заступала свој захтев о признавању њених мањина у суседним државама, док је тврдоглаво одбијала да прихвати било какве обавезе које би признавали status quo. И поред ове чињенице, постојали су групе унутар бугарских политичких кругова које су биле наклоњене балканским интеграцијама, у страху од надолазеће опасности агресије немачких и италијанских снага ${ }^{17}$. Једини корак који је начинила ревизионистичка Бугарска био је да се полако приближи Југославији после избора 1931.

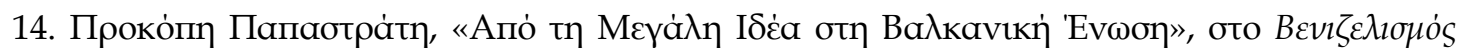

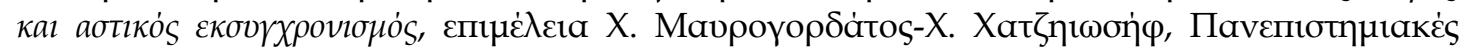

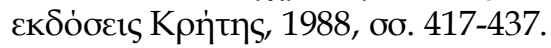

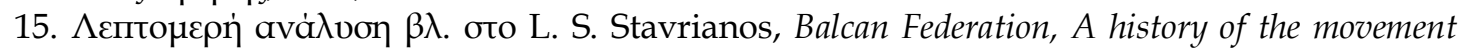
towards Balcan Unity in modern times, Hamden, Archon Books, 1964, oo. 231-234.

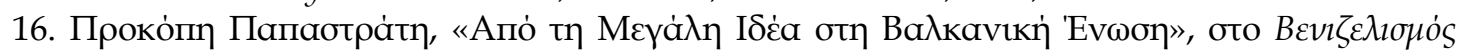

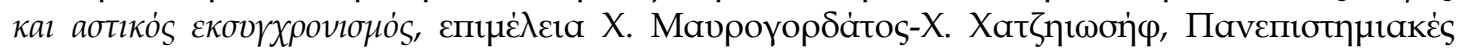

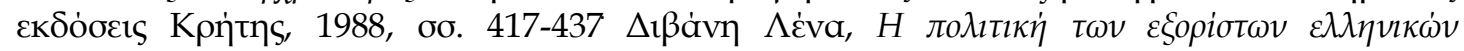

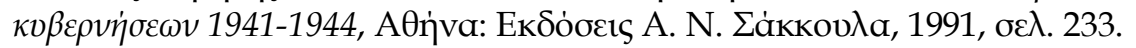

17. Campus Eliza, The Little Entente and the Balcan Alliance, Biblioteca Historica Romaniae,

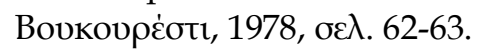


године, када се и удаљила од владе група која је легализовала незаконите радње ВМРО-а. Услед страха који је проузроковало ово словенско приближавање, предложени бугарско-југословенски споразум није помогао, већ је само активирао механизме одбране осталих балканских држава.

Од 1933. године међународна криза је погоршана успоном Хитлера и ревизионистичког фронта. Мир је постао једна врста неизвесног добра, а угрожене балканске земље су имале потребу да постигну колективни механизам одбране. Тако су сасвим напустили визију балканских интеграција, ужурбано потписујући у фебруару 1934. године један политички споразум који није обећавао много. Учествовале су само Грчка, Турска, Југославија и Румунија. Бугарска је, упркос покушајима осталих земаља, до краја одбијала да учествује притиснута од стране Италије која је сматрала алармантим ову тенденцију балканских интеграција ${ }^{18}$.

Исти притисак Италија је вршила и на Грчку. Венизелос, који није желео да поквари пријатељске односе са Италијом, веровао је у то да би балканско уједињење без Бугарске било бескорисно. Са једне стране, то би могло Грчку да доведе у конфликт са неком великом силом (карактеристичан пример представља случај напада Италије на Југославију преко Албаније. У овом случају Грчка би требала да помогне Југославији борећи се против Италије), док би с друге стране довело до отуђења Бугарске и потпуно би је окренула према Силама Осовине. У овом тренутку утицај великих сила је одиграо разарајућу улогу и поново није успела да се успостави балканска хармонија. То је била иста врста политике која датира још из XIX века ${ }^{19}$.

18. Campus Eliza, The Little Entente and the Balcan Alliance, Biblioteca Historica Romaniae,

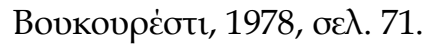

19. Према Ставрианосу, од 19.века политика великих сила је била да држе радвојене државе на Балкану. Чак и кад би једна велика сила покушала да створи балкански блок, то је радила да би покрила неке своје потребе (L. S. Stavrianos, Balcan Federation, A history

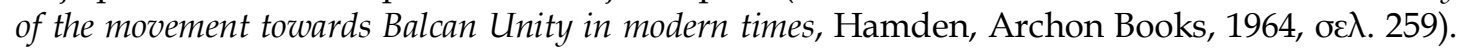
Треба истаћи да ни комунистички и социјалистички покрети балканских земаља нису веровали у уједињене региона. Били су против, сматрајући да би таква заједница 
Јачање Сила Осовине, и њихов економски продор у балканске земље, су довели до прекида споразума из 1934. године. Грчка и Турска су благовремено разјаснили да договор не би важио у случају напада велике силе, подразумевајући прво Италију, а затим и Совјетски Савез. Метаксас се побринуо да након 1936. године изостави албанску границу из гаранција споразума. У Румунији, Н. Титулеску је изгубио владу и његов наследник се окренуо Немачкој и Италији, уплашен због тенденција Совјетског Савеза у Бесарабији. У Југославији, која је почела да се приближава Силама Осовине, напуштајући ослабљену Француску, М. Стојадиновић је 1937. године потписао италијанско-југословенски споразум о пријатељству. Уплашени од агресивности ревизионистичких држава, Балканска Антанта, тј. неколико држава које су преостале, закључиле су пакт о ненападању са Бугарском, без било каквог помињања поштовања status quo ${ }^{20}$. Недуго затим, Други Светски рат је започео и затекао Балкан подељен и незаштићен ${ }^{21}$.

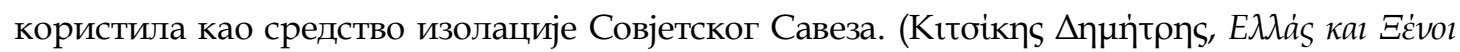
1919-1967, Eotia, AӨj̀va, 1977, oo. 78-79).

20. Почетак овог периода „спашавај се ко може“ описан је успешно у делу L. S. Stavrianos, Balcan Federation, A history of the movement towards Balcan Unity in modern times, Hamden, Archon Books, 1964, oo. 239-260.

21. $\Delta$ ı

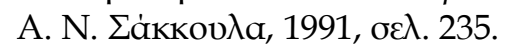




\section{ПРВО ПОГЛАВЉЕ}

\section{ИЗБИЈАҢЕ ДРУГОГ СВЕТСКОГ РАТА И ПУТ ГРЧКЕ ВЛАДЕ У ИЗБЕГЛИШТВО}

\section{1 ИЗБИЈАҢЕ ДРУГОГ СВЕТСКОГ РАТА}

Други светски рат отпочео је нападом Немачке на Пољску, 1. септембра 1939. године. Моћне немачке војне снаге су напредовале таквом брзином са којом се свет до тада није суочио. Главни град Пољске пао је 27. септембра. Десет дана раније, у Пољску су ушли и Совјети да би преузели контролу над територијама које су били обезбедили Немачко-совјетским уговором склопљеним претходног месеца22.

У сенци овог обрачуна великих сила, у зиму 1939-1940. године, избија и један локални рат између Финске и СССР. Међутим, овај рат није био независтан од обрачуна великих сила с обзиром на то да је био индиректна последица Немачко-совјетског уговора (Финска је била део сигурносне зоне коју је од Хитлера издејствовао Стаљин). Након припајања Источне Пољске, Совјетски Савез обезбедио је споразуме са Летонијом, Литванијом и Естонијом, који су Стаљину омогућили да утврди базе у балтичким земљама, а касније да обезбеди и политичку моћ. Слични предлози Совјетског Савеза Финској нису били прихваћени, а последица је била избијање рата између ове две земље 23.

Финска, која се тек била ослободила надзора царске Русије и развила се једну од најнапреднијих држава у међуратном периоду, пружала је велики отпор. Знатно надмоћнијим снагама Совјетског Савеза било је потребно четири месеца да савладају отпор који су пружале

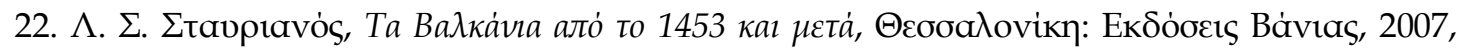

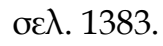

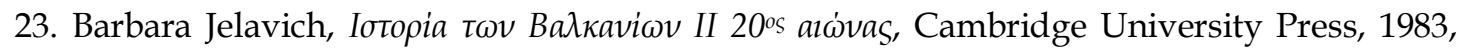
ов入. 348' Стеван К. Павловић, Историја Балкана, Београд: CLIO, 2001, стр. ' I. $\Sigma$.

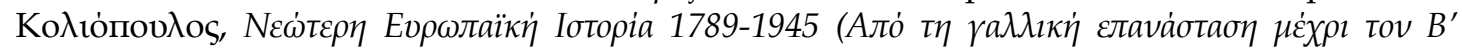

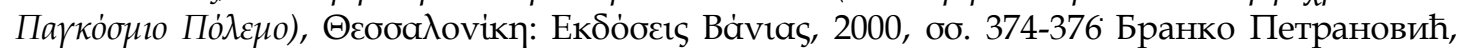
Историја Југославије 1918-1978, Београд: Нолит, 1981, стр. 168-169. 
добро обучене и опремљене финске трупе. Коначно, марта 1940. године Совјети успевају да разбију финску одбрану и да на силу припоје територије коју је од почетка желео Стаљин.

Норвешка је исте зиме постала циљ Немачке, која је покушала да је анектира, пошто је одатле могла да угрожава сигурност Британије и да лакше преноси метале из Шведске. Априла 1940. године моћне немачке снаге напале су Норвешку преко Данске, али су наишле на велике проблеме у току искрцавања у фјордовима. Норвежани су, иако затечени, успели да потопе неколико немачких ратних бродова и да са својих утврђења проузрукују велику штету агресорима. Савладан је отпор одбране, тако да је већ било исувише касно када су експедиције Француске и Британије стигле. Јужни део земље окупирала је Немачка, док се само у северном делу, са центром у Нарвику, наставио отпор Норвежана и њихових савезника све до краја маја. Окупатори су Норвешкој наметнули фашистички режим под Видкуном Квислингом ${ }^{24}$. Насупрот овоме, Немци у Данској нису дирали владу и Краља, највише због чињенице што је Данска била толико слаба да није била у позицији да угрози безбедност Немачке. Данска је, иако је пала под немачку окупацију, задржала свој режим. Од свих скандинавских земаља само је Шведска остала неутрална током читавог рата 25.

У мају су на ред дошле „земље са југа“ да би се отворио пролаз од Немачке ка Француској. Прва је, без упозорења, била нападнута отворена и равничарска Холандија, која је поражена за неколико дана. Тежим се показало освајање Белгије. Белгијанци су своје снаге концентрисали у утврђењима док су Французи и Британци послали снаге у унутрашњост земље да би подржали белгијску одбрану. Када је отпочео напад, све се одвијало онако како су предвидели агресори.

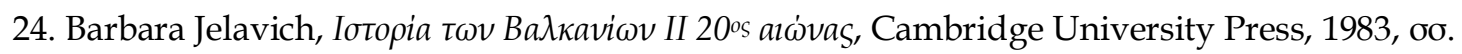
348-349 Бранко Петрановић, Историја Југославије 1918-1978, Београд: Нолит, 1981, стр.

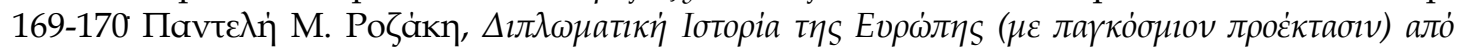

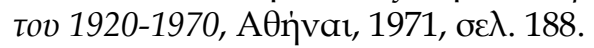

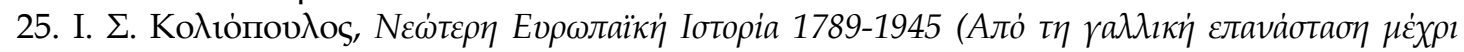

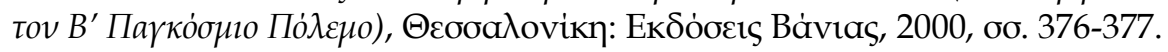


Белгијска одбрана савладана је много раније него што су то очекивали Французи и Британци. Француске и британске трупе биле су од почетка приморане да се повлаче са територија које нису биле добро припремљене за задржавање немачке војске. Пролазећи кроз шумовите пределе Ардена, заобилазећи или разбијајући утврћену линију Француске на граници са Белгијом, немачке снаге рашириле су се према југу и западу и успеле да разоре одбрамбени механизам Француске пре него што је он уопште и почео да функционише. Треће недеље маја, недељу дана након напада, снажне немачке снаге усмеравале су се према југу, док су се Французи повлачили без пружања озбиљнијег отпора. Недуго затим, Белгијанци су били приморани да положе оружје, а влада је пребегла у Лондон.

Агонија Француске је у међувремену достигла свој врхунац. Поред немилосрдног напада Немачке, 10. јуна рат јој објављује и Италија, што је имало више симболичан карактер. Наиме, Мусолини је журио да објави рат Француској и Британији да би Италија извукла користи из очекиваног пада Француске. Средином месеца пао је и Париз, а влада је напустила земљу. Петен је, 17. јуна, Немцима послао изасланике ради склапања примирја. Пет дана касније, када су Немци већ освојили пола Француске, у шуми Компјењ, у истом вагону воза у коме су Французи били наметнули услове пораженим Немцима новембра 1918. године, Хитлер је наметнуо своје услове пораженим Французима. Трећа Француска Република окончана је и званично гласом парламента који је добијен под притиском и утицајем пораза и понижења26.

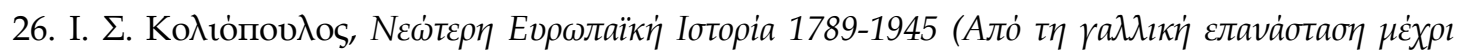

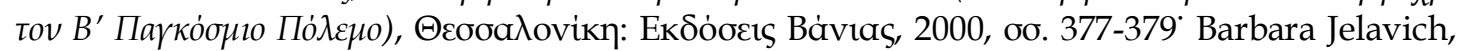

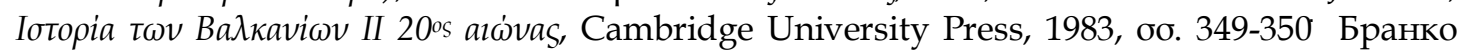

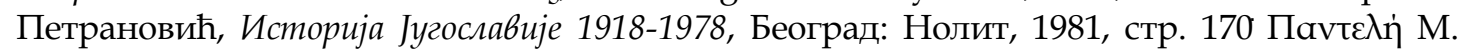

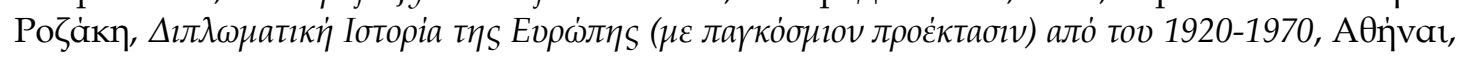
1971, oع入. 189. 


\section{2 ГРЧКА У ТОКУ ДРУГОГ СВЕТСКОГ РАТА}

Грчка, званично неутрална, али у суштини пријатељски настројена према Британији, дочекала је напад Италије на њене територије углавном као земља која је могла да буде употребљена од стране Британаца да се удари на Италију и њене позиције на Егеју. Годину дана након Мусолинијевог успона, и поводом инцидента на грчко-албанској граници (27. августа 1923 године убијен је италијански официр, члан међународне комисије за постављање граница), 31. августа 1923 године Италијани су освојили Крф, са ког су се повукли након притиска осталих великих сила. Италија није крила своје освајачке намере према Грчкој, како острвском, тако и према њеном континенталном делу. Падом Албаније 1939. године, Италија је стекла и копнену границу са Грчком и тако почела да представља директну претњу.

Метаксасова влада, поред традиционалне наклоности самог Метаксаса према Немачкој, остварила је и тесне пријатељске везе са Британијом и одређене споразуме, који, иако економске природе, показивали су политичку оријентисаност Грчке. Нарочито важни били су споразуми потписани октобра 1939. године и јануара 1940. године којима је Грчка са једне стране прихватила да сведе на минимум извоз у Немачку, а са друге да „изнајми“ Британској влади велики део своје трговачке флоте 27. Резултат ових споразума био је потпуни прекид трговине између Грчке и Немачке све до лета 1940. године. Такође, Немачка и Италија су постале свесне наклоности Грчке владе према Британији. Напад Италије на Грчку био је у служби њених старих освајачких тежњи, али је Италија такође хтела да удари на једну земљу која је била све више окренутија Британији.

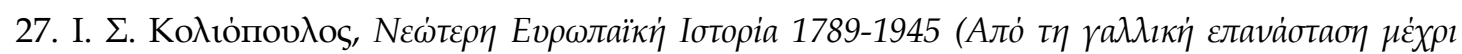

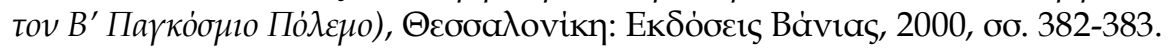


И Британија и Немачка имале су своје разлоге због којих су желеле да Грчка остане неутрална - Британија због тога што је јој је пријатељска политика Грчке обезбеђивала све привилегије једног савезништва без обавеза које би такав један однос доносио, а Немачка јер је страховала да би улазак Грчке у рат олакшао стационирање британских ваздухопловних база у земљи, из којих би нафтна поља у Румунији била лака мета. Иначе, очекивало се да би улазак Грчке у рат могао да изазове општи сукоб на Балкану, и да на тај начин поремети транспорт природних сировина из ове области ка Немачкој.

Грчко-италијански рат је почео 28. октобра 1940. године и трајао је све до интервенције Немачке. До тада је Грчка ратовала сама, уз оскудну помоћ Британије, и извојевала прву победу против Осовине, уз дивљење и савезника и непријатеља. И поред недостатака у организацији оружаних снага, и инсистирања политичког и војног вођства на једној дефанзивној политици, која је била под утицајем одговарујуће француске политике али и наметнута опасностима које је стварала Бугарска, оружане снаге Грчке не само да су истерале нападача са грчке територије, већ су убрзо напале и Албанију - градове и села у Северном Епиру, где су грчки војници били дочекани као ослободиоци. Међутим, доласком зиме заустављено је и напредовање грчке војске22.

У овој фази рата, децембра 1940. године, Немачка је покушала да посредује између Италије и Грчке да би се окончао њихов међусобни сукоб. Међутим, Метаксас је одбацио посредовање Немачке уверавајући истовремено Британију да би Грчка ратовала на њиховој страни до коначне победе против сила Осовине и против Немаца, ако би ови одлучили да нападну Грчку. То је била једна храбра одлука која је свесно обележила став Грчке током читавог Другог светског рата. Немачки предлог је изгледао примамљив, јер би окончао сукобе без даљег губљења територија. Међутим, оцењено је да би капитулација земље

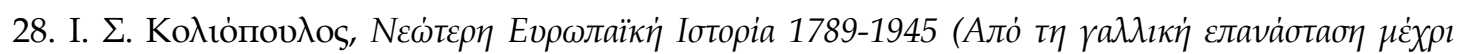

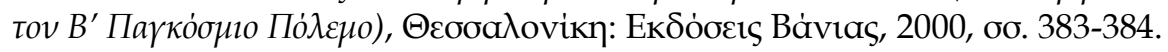


изложила опасности највише националне циљеве. У случају да победе Британија и њени савезници, било је вероватно да не би били задовољене националне претензије Грчке, и можда би чак били наклоњенији интересима Турске која је водила неутралну политику. Међутим, очекивало се да ће се Турска приклонити страни која је имала веће изгледе да победи (како је и било), док се, у случају да победе силе Осовине, сматрало вероватним да би како Италија тако и Бугарска, која је била наклоњена Осовини, у први план ставиле своје захтеве запостављајући Грчку. Цена одбијања да се земља усклади према условима Немачке била је велика, али од стране владе је оцењено да је вредно жртве 29.

Смрћу диктатора Метаксаса, јануара 1941. године, Грчка је остала без снажног државног вођства. Краљ Георгиос II, и поред своје преданости политици коју је водила влада још за време Метаксаса, није био у позицији да је наметне и да прати њену примену у свим њеним фазама. Наследник Метаксаса на место премијера, Александар Коризис, није успео да промени став војних лидера албанског фронта који су сматрали да малена и исцрпљена Грчка није у стању да предузме нове војне акције, овог пута против Немачке, посебно у тренутку када Британија није могла да пошаље значајнију помоћ на фронту у Македонији, а Југославија је избегавала да синхронизује своје акције са грчким и британским акцијама за стварање заједничког фронта против Немачке. Разни пропусти Генералштаба, а нарочито врховног војног команданта, Александра Папагоса, притисак Британије да пошаљу било какву помоћ коју су могли да повуку са Блиског Истока (где су задали одлучујући ударац Италијанима, али где су се суочавали и са могућим нападом Немаца који су концентрисали своје снаге на северу Африке), као и одлука владе да се, поред Албанског фронта и Метаксасове линије на грчко-бугарској граници, створи и трећа линија одбране у 
Централној Македонији, предодредили су не само брз пад отпора против немачког напада 6. априла, већ и стварање озбиљних раскола у политичком и војном врху са озбиљним последицама у политичким дешавањима периода који је следио ${ }^{30}$.

Напад Немачке на Југославију и Грчку, након приступања Бугарске, Мађарске и Румуније силама Осовине (потписивање Тројног пакта), предузет је, не само ради ојачања међународног положаја Италије, већ углавном да би се неутралисало ратно жариште на Балкану које би могло довести до стационирања британских база у Грчкој, одакле је могло да буде угрожено десно крило војних снага које је требало да ускоро нападну СССР. Немачка страховања била су наравно преувеличана, али болна искуства из Првог светског рата и могућност настанка фронта на Балкану, налик Македонском, утицали су на њихову одлуку да неутралишу ратно жариште у Грчкој и да на тај начин протерају Британце. Хитлерова одлука о нападу на Југославију била је реакција на војни пуч од 27. марта 1941. године којим је свргнута филогерманска влада и принц регент Павле, а на трон доведен Петар II. Влада Д. Симовића је покушала да увери немачку владу да Југославија неће да поништи уговор од 25. марта ${ }^{31}$.

Савладавши најпре југословенски отпор, Немци су снажно напали Грчку преко Битоља. Након краткотрајног отпора на линији Алиакмон, грчко-британске снаге повукле су се према југу, остављајући слободан приступ ка Епиру, централној и источној Македонији. Борци са Метаксасове линије били су приморани да положе оружје након кратког, али храбро пруженог отпора. На Албанском фронту војне вође вршиле су притисак на владу и врховног команданта да преузму одговорност склапања споразума између грчке војске и Немачке. Наређење повлачења војске према југу, пре него Немци заузму Епир, издато је веома касно (11. априла), са последицом да се војска нађе између

30. Ричард Клог, Историја Грчке новог доба, Београд: CLIO, 2000, стр. 123.

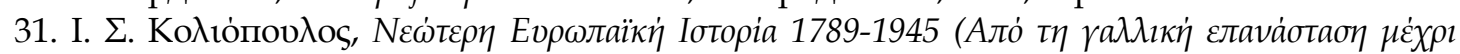

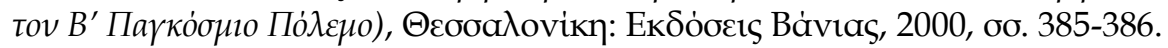


Италијана и Немаца. Грчка влада није могла да преузме иницијативу потписивања споразума са Немачком све док су се на грчкој територији бориле британске јединице, нити је било могуће да дозволи такву иницијативу војном вођству фронта, да се држава не би замерила Британији. Вође фронта, са друге стране, суочавали су се са дилемом да не капитулирају и на тај начин војску доведу у опасност да буде заробљена од стране већ поражених Италијана, или да капитулирају и компромитују државу, и да при том буду окарактерисани као издајници. Одлучили су се за капитулацију без сагласности владе, која није признала овај чин напустивши престоницу заједно са краљем Георгиосом II.

Грчка влада и краљ, заједно са преосталим члановима британског експедиционог корпуса из континенталне Грчке, пребегли су на Крит, у нади да ће острво остати ненападнуто. Међутим, у мају су Немци извршили снажан ваздушни десант на Крит. Након жестоких борби на обалама и у ваздушном простору Крита, коначно је савладан отпор критске одбране и Немци су заузели Крит. Међутим, цена коју су Немци платили да би освојили острво били су велики губици у људству и ратној техници. Одабрана падобранска јединица која је учествовала у овом нападу имала је толико жртава да у будућности није могла бити искоришћена у оваквим подухватима.

Земља је тако пала под немачку и италијанску окупацију, али такође и под бугарску, која је искористила прилику да пошаље своје окупаторске трупе у Грчку. Управљање земљом преузела је на себе влада састављена од генерала Албанског фронта, на челу са Георгиосом Цолакоглуом, који је прихватио да формира владу на наређење Немаца. Законита влада Грчке, на челу са Краљем Георгиосом II, пребегла је у Египат, а одатле у Британију. Тамо је пребегла и Југословенска влада, на челу са Краљем. У пролеће 1941. године, пре немачког напада на Совјетски Савез, избегличке владе шест окупираних земаља Европе биле 
су једини савезници Британије. Међутим, назирали су се нови развоји догађаја који ће променити ток рата 32.

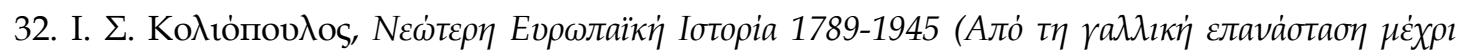

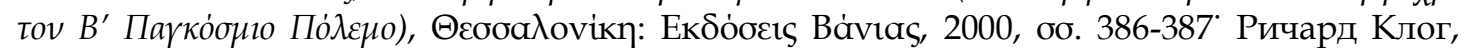
Историја Грчке новог доба, Београд: CLIO, 2000, стр. 123-127. 


\section{3 ИЗБЕГЛИЧКЕ ВЛАДЕ У ЕВРОПИ}

Избегличке владе представљају специфичан наставак државног континуитета, који постаје неопходан након почетка Другог светског рата, због територијалних комешања и војне окупације великог дела Европе од стране сила Осовине. Ове владе, спречене да врше власт на територијама својих држава, одликовале су се тако разноврсним карактеристикама, да би чак и данас било погрешно сврстати их у исту групу и према истим критеријумима, нарочито што се тиче суштинског питања њиховог легитимитета. Неке су биле законски изабране, неке су представљале шири „спектар“ политичких снага својих земаља, док су друге просто биле постављене. Све су, међутим, биле савезничке.

Биле су савезничке и по правилу смештене у Лондону, након освајања Пољске, Белгије, Холандије, Луксембурга, Норвешке, Француске, Чехословачке, Југославије и Грчке од стране војних снага Осовине. Неке од влада из Лондона, преселиле су се у Каиро, Јоханесбург и Вашингтон. Пољска избегличка влада, иако је била изгубила подршку и признавање државе домаћина, остала је у Лондону до 198933.

Студије о политикама ових влада, које су се одликовале објективним слабостима и које су у неким моментима показивале одређене реакције или чак потпуну инертност, постоје у фрагментима. Већина тих студија односи се углавном на случајеве Пољске и Југославије, пошто су након рата ови случајеви пресудно утицали на ток сукоба између Истока и Запада. Што се Грчке тиче, малобројне студије спољне политике које покривају период Другог светског рата, садрже по правилу анализе и процене билатералне природе, дакле испитују углавном везе са Великом Британијом, САД, СССР, и у мањој мери са осталим балканским државама.

33. $\Delta$ ı

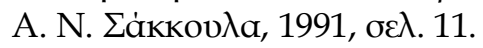


Ограничена способност деловања избегличке владе Грчке била је последица колико стране окупације земље, толико и већ постојећих унутрашњих проблема, као што су сиромаштво и обнављање политичких снага током међуратног периода које није уродило плодом, непрестани преврати, интервенције војске, продужење раскола и недостатак легитимитета изабране владе, и то у тренутку када је Грчка и званично ушла у Други светски рат. Управа земље у условима избеглиштва, поред додатних уставних и проблема око међународног права, покретала је и многострука практична питања у вези са доношењем одлука, начинима утврђивања политике и њеним последицама. Поврх свега, влада у избеглиштву недостатке у свом саставу и деловању може приписати и страном мешању у грчка питања. Током Првог светског рата постојао је снажан страни утицај на политички живот Грчке, који је завршио расколом, али тада смо имали појаву ривалитета између две групе страних држава. Насупрот томе, за време Другог светског рата контролу над Грчком владом имала је у потпуности само једна држава - Велика Британија ${ }^{34}$.

Иако су се ове владе састојале од малог броја чланова, није било могуће постизање сагласности међу њеним члановима. Њихово деловање било је мањкаво и лошег квалитета, што се види и у раду њихових дипломатских служби. Поред тога, много је разлога због којих је присуство војске било сведено на минимум, што је још више погоршавало већ негативну слику тих влада. Могло би се наравно тврдити да су избегличке владе имале више улогу психолошког карактера, наглашавале су дакле одлучност народа под окупацијом да наставе борбу на страни савезника, а против сила Осовине. Карактеристичне су и многе друге одлике, као што су неједнака посвећеност избегличких влада према савезницима, немогућност успостављања доследне и дугорочне спољне политике, неозбиљно

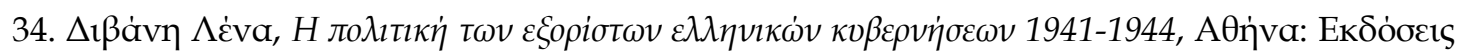

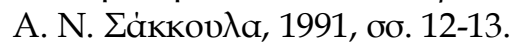


суочавање са потенцијалном моћи њихових сународника из дијаспоре, нарочито у САД, као и политика Грчке у послератном периоду за коју нису биле карактеристичне иницијативе већ супростављање истим. Један такав пример било је и приближавање Грчке Југославији, на иницијативу Британије, ради остваривања плана балканског уједињења, са циљем избацивања Совјетског Савеза са Балканског полуострва. Међутим, муњевито погоршање веза Истока и Запада, после 1945. године, укључујући и грађански рат у Грчкој, учинили су овај план неостварљивим ${ }^{35}$.

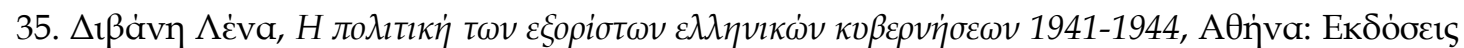

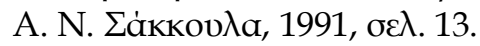




\section{4 МЕЂУНАРОДНО-ПРАВНИ РЕЖИМ ИЗБЕГЛИЧКИХ ВЛАДА}

Поред политичке и економске зависности грчке избегличке владе, треба да испитамо и једну другу димензију која је још више отежавала њену ефикасност. У питању су проблеми који су настали из правног режима избегличких влада. Феномен политичке и правне специфичности владе која своју власт спроводи у условима избеглиштва, дакле са територије друге државе, појавио се први пут током Првог светског рата, и то у неколико случаја: Белгијска влада, која је била стационирана у Сант Андресу у Француској, влада Црне Горе са седиштем у Италији и Српска влада, која се налазила на Крфуз6. У Другом светском рату, овај феномен да се седишта владе сваке европске земље покорене од стране немачких снага, премешта на слободну територију, да би одатле наставила своје деловање, био је уобичајен. Тако је, од 1940. године па надаље, у Лондону, који је био центар савезничке борбе, настала једна минијатура Европе састављена од влада Белгије, Луксембурга, Норвешке, Чехословачке, Грчке, Југославије, Пољске, Холандије и тзв. "слободне“ Француске, која није у потпуности уживала привилегије режима осталих избегличких влада ${ }^{37}$.

Постојање и деловање ових влада представљало је један правни парадокс: претендовале су на вршење власти над територијама и народом који су били под страном окупацијом. Нису постојала законодавна тела да доносе законе, јер је ретко кад било могуће да неко од њих са свим својим члановима напусти земљу и оде у Лондон ради доношења закона. И да су постојала, питање је коју снагу може да има један закон који се примењује на тлу стране државе и која судска власт би имала контролу над његовом применом. Један други важан проблем

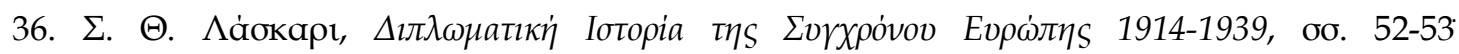

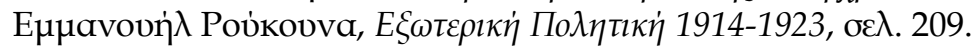

37. Детаљьије за сваку од ових влада види Lucy Sayre, Freedom in Exile: a Handbook of the Governments in Exile, London, 1943. 
био је признавање ових влада од стране народа и њихова неизвесна будућност. Карактеристичне су најоштрије политичке несугласице које су непрекидно избијале, како између чланова унутар једне владе, тако и међу самим владама. Ситуацију је још више компликовао један низ слободних покрета (Слободни Аустријанци, Слободни Мађари, Слободни Албанци итд.) који су тврдили да они представљају своје земље, али који, из различитих разлога, нису били признати од стране савезника.

Са правног аспекта, признавање легитимитета влада у Лондону након напада и окупације њихових земаља од стране сила Осовине, заснивало се на раније установљеном принципу Међународног права у вези са occupation bellica, према којем непријатељска окупација не нарушава суверенитет окупираних држава. Окупатор не заузима место легитимне владе над окупираном државом, већ инсистира на власти заснованој искључиво на употреби силе. Ове владе, које су настављале своје деловање у иностранству ради опстанка државе, правници једногласно сврставају у категорију de facto влада ${ }^{38}$. Да би олакшала њихов рад, британска скупштина признала је, 6. марта 1941. године члановима савезничких избегличких влада, као и њиховом званичном особљу, дипломатски азил и повластице. Избегличке владе задржавале су још право да примају стране дипломатске представнике и да шаљу своје дипломате у земље са којима су одржавале дипломатске везе.

Можда због комплекса ниже вредности што се тиче њихове правне основе, избегличке владе су сваком приликом са једнаком званичношћу потписивале све врсте уговора, споразуме, савезништва или декларације. Свака појединачно потписала је војни споразум са Великом Британијом. Између осталог, потписани су чешко-пољски споразум од 11. новембра 1940. године, грчко-југословенски споразум од 15. јануара 1942. године, који је тежио да постави темеље уједињеном Балкану,

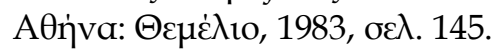


споразуми Чехословачке и Пољске са Совјетским Савезом о смештању војске на руске територије и споразуми са САД о зајму и најму оружја и другог материјала за потребе антихитлеровске коалиције. Треба такође нагласити да су све избегличке владе заједно са Француском, Британијом са Колонијама и Совјетским Савезом биле чланице Међусавезничког савета, који је, после два заседања 12. јуна и 24. септембра 1941. године престао са радом након што је претходно изјавио да подржава принципе Атлантске повеље ${ }^{39}$.

Избегличке владе показале су такође велику законодавну активност, поред проблема који су постојали у вези са уставним и међународним правом. Аргумент који је усвојен да би се избегли проблеми које је изазивало међународно право, била је чињеница да није постојао сукоб надлежности између законодавних тела Британије и сваке избегличке владе пошто су избегличке владе доносиле законе искључиво за своје држављане, што је прихваћено од стране британског парламента. Да би се суочила са проблемима уставног права, свака влада дала је решење устава, обично без претходне припреме, засновано на уставима који су били на снази пре непријатељске окупације.

Случај Грчке био је прилично компликован. Јоанис Метаксас је потиснуо Устав из 1864/1911. године доневши два указа од 4. августа 1936. године. На овај начин Устав из 1864/1911. године никада није званично укинут ${ }^{40}$. Влада Цудероса је, превидевши укидање Устава, донела Уставни акт 22. октобра 1941. године да би допунила оне његове делове који нису могли да се примене због постојеће ситуације. Према овом акту, након предлога Цудеросове владе, законодавну власт вршио је Краљ Георгиос II. Четвртог фебруара 1942. године Краљ Георгиос, под притиском, потписује Уставни акт којим изричито укида Метаксасов

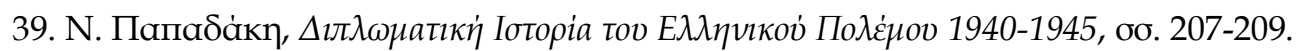

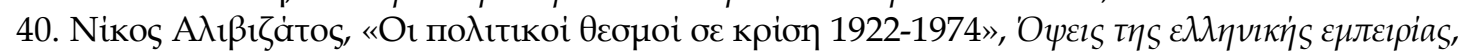

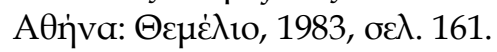


указ који је ускраћивао личне слободе ${ }^{41}$. За примену законе Уставни акт од 22. октобра 1941. године предвиђао је специјалне судове које би одређивала влада ${ }^{42}$. Једна од најосетљивијих тачака, са правног становишта, било је регулисање стационирања наоружаних снага избегличких влада на страном тлу. У складу са Међународним правом регрутација на територији стране државе представља ограничавање доминације те државе. Штавише, ако се поменута војска налази на неутралној територији она мора да се разоружа и да не предузима ратне акције.

Проблем са Британијом је решен и стационирање страних армија сматрало се легалним, пошто је претходило склапање војног споразума са овим земљама. Правни режим оружаних снага избегличких влада био је уређен Законом о савезничким снагама из 1940. године као и одредбама војног споразума који је Британија склопила са сваком заинтересованом избегличком владом. Овај закон гарантовао је британским судовима надлежност над сваким чланом савезничке војске који би прекршио британске законе, осим у питању америчких војника. Само су за питања дисциплине и унутрашњег уређења искључиву надлежност имали савезнички војни судови, али уз опрезност да истовремено не наруше британске законе.

Грчко-британски војни споразум потписан је 9. марта 1942. године ${ }^{43}$. По овом споразуму грчка војска налазила се под врховном британском војном командом. У случају кршења Закона о дисциплини и унутрашњем уређењу, а у складу са Законом о савезничким снагама, овај споразум предвиђао је суђење према грчком војном праву и од стране грчких војних судова ${ }^{44}$.

41. A. Kitroeff, «Governments in Exile, Legal Succession and Related Problems: The Greek Case», British International Studies Association, 1979.

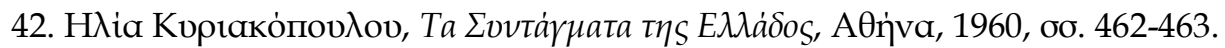

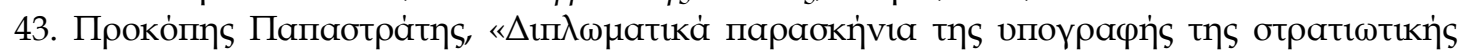

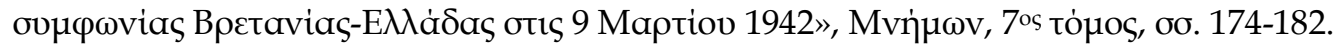

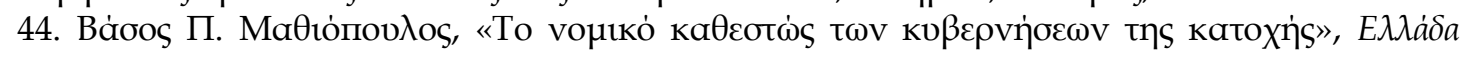

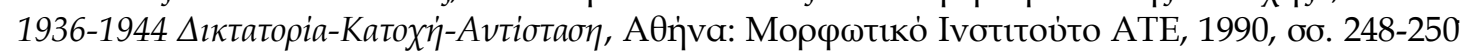
F.O. 371/ 32206, R3793. 


\section{5 СЛАБО ФУНКЦИОНИСАЊЕ ИЗБЕГЛИЧКЕ ГРЧКЕ ВЛАДЕ КАО ПОСЛЕДИЦА ЗАВИСНОСТИ ОД ВЕЛИКЕ БРИТАНИЈЕ}

Боравак грчке избегличке владе у Египту трајао је око месец дана. Ово звучи доста парадоксално, јер је изгледало природно да након пада Крита, ова област постане срце слободног хеленства и центар непосредно повезаних политичких дешавања. Разлози су очигледни. Пре свега, у Египту је од давнина расла једна многобројна и активна грчка заједница која је 1937. године бројала око сто хиљада грађана45. Затим, географски положај ове земље био је такође битан фактор у комуникацији са окупираном Грчком. Такође, Египат се познатим енглеско-египатским споразумом од 1936. године, обавезао према Британији да ће јој у време рата дозволити да на његове територије смести своје војне, поморске и ваздухопловне базе ${ }^{46}$. Избијањем Другог светског рата, Египат се практично нашао у условима окупиране државе, пошто је у суштини власт прешла у руке Британаца.

Проблем будућег стационирања грчке избегличке владе дуго је оптерећивао како Грке, тако и Британце. Расправљало се о Палестини, на шта је негодовао Краљ Георгиос, о Кенији, која се никоме није довољно допадала, и о Кипру, који је одбачен као решење због очекиваних енглеских примедби. Форин офис је логичнијим решењем сматрао Лондон, а не Блиски Исток, који је у то време био опасна зона због избијања сукоба у тој области ${ }^{47}$. На крају, непосредно након немачког напада на Крит, Краљ и Цудерос пребачени су на Блиски Исток, а да то није званично објављено да не би неповољно утицало на

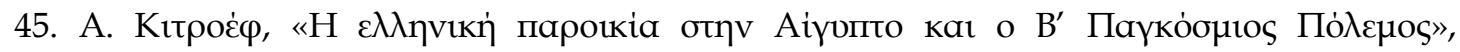
Mvทं $\mu \omega v$, tóнos 9os, 1984, oo. 1-32.

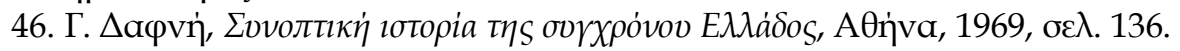

47. P. Papastratis, British policy towards Greece during the Second World War1941-1944, Cambridge: Cambridge University Press, бєג. 7. Убрзо међутим, став Форин Офиса се мења, као и ситуација, па се стационирање избегличке грчке владе у Египту сматра најбољим могућим решењем. 
морал бораца на Криту. Међутим, велика очекивања о смештању у Египат убрзо су се показала неутемељеним. У том тренутку Египатска влада није била званично ушла у рат и тежила је томе да сачува утисак о својој наводној неутралности ${ }^{48}$. Премијер Сири-паша и Краљ Фарук покушали су да се одупру притиску Британаца, што је у великој мери подигло тензију у Форин офису. Нису били расположени да угосте избегличку владу Грчке и то су од самог почетка отворено показивали. Невољност египатских власти потврдила је и британска амбасада у Каиру, која је обавестила Краља Георгиоса да би било боље када би прихватио позив Џ. Сматса, да се дакле на кратко сместе у Северној Африци и да на крају оду у Лондон, где је било седиште и других савезничких избегличких влада ${ }^{49}$. Једини уступак који је начинила Египатска влада био је тај што је допустила боравак грчких оружаних снага, под логиком да су биле под контролом британског штаба на Блиском Истоку. Остала су такође и три ратна министарства и потпредседник владе, адмирал Сакеларију ${ }^{50}$.

Мало касније, почетком 1942. године, Британска влада одлучила је да уклони ограничења слободног кретања, коју јој је наметала влада Сири-паше, те је опкољавањем Фарукове палате оклопним возилима за премијера поставила Наха-пашу, који је био наклоњенији Британији и вољнији за сарадњу. Влада Наха-паше са задовољством је 1943. године

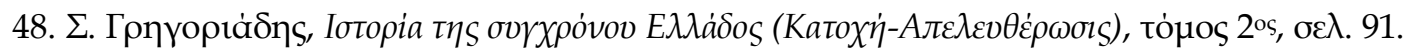
49. Е

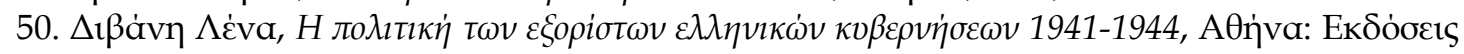
А. N. $\Sigma$ áккоטגa, 1991, бб. 39-40. Георгиос, престолонаследник Павле и његова породица, заједно са Цудеросом и министрима Димитратосом и Николаидисом су 27.јуна 1941. године испловили ка Африци бродом Њу Амстердам. У Александрији остају

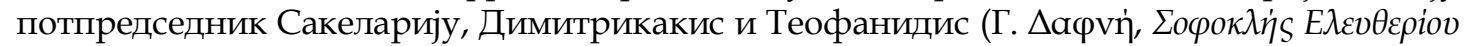

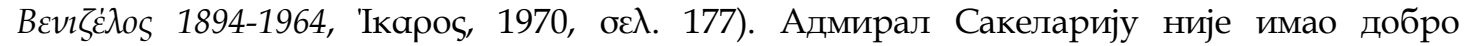
мишљење о Цудеросу, којег је с презиром називао „банкаром“. Подозривост је међу њима била узајамна и раскол међу њима је био неизбежан. Адмирал је ускоро напустио потпредседништво учинивши услугу Канелопулосу, пошто је Цудеросов утицај непрестано растао у краљевим очима, иако је адмирал био познати ројалист (А.

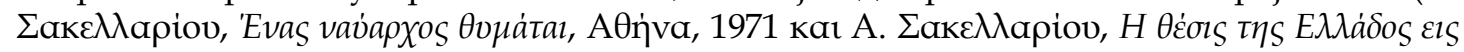

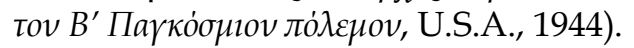


прихватила пребацивање седишта грчке избегличке владе у Каиро ${ }^{51}$. Тог тренутка, међутим, влада Цудероса и Краљ започели су свој пут у најнеповољнијим условима, који су драстично ограничили њихову слободу кретања. Један велики проблем са којим је требало да се суоче од самог почетка, осим египатске нетрпељивости, био је и резервисан став велике грчке заједнице, која је наметнула смену владе 2. јуна 1941. Године, што је предсављало и прву демократизацију владе. Познато је да грчка заједница у Египту никада није прекинула везе са националним центром и највећи број њене популације био је под утицајем либералне партије, подржавајући током читаве његове политичке каријере, активног присталицу модернизације Елефтериоса Венизелоса, идеалног вође њихове класе. С обзиром да Краљ и избегличка влада нису имали алтернативне могућности контакта са народом у окупираној Грчкој, и да је највернији „узорак“ грчке популације који им је био на располагању били Грци из Египта, било је очигледно да ће морати да буду јако вешти у својим мманеврима да би се избегла криза 52.

Невољност Египатске владе да прими грчку избегличку владу, обезбедила им је згодно оправдање да се привремено ослободе проблема. Седиште владе у Лондону било је тако далеко од усијане атмосфере на Блиском Истоку, од египатских и острвских избеглица, од војске и пригушених негодовања, тако да није постојала никакава обавезујућа потреба за доношењем одлука и усвајањем радикалних решења. На овај начин су изгубљене и најмање шансе да буду у директном контакту са грчким јавним мњењем ${ }^{53}$. Као што је написао

51. А. Кıтров́

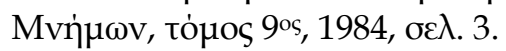

52. У лето 1941. године још увек није била организована мрежа тајних информација из окупиране Грчке, што је значило да су се гледишта колоније у Египту у односу на ставове оних који су били избегли из окупиране Грчке користили као вид замене док се не утврди метод на који ће се начин вршити пренос информација из Грчке (А. Кıтров́

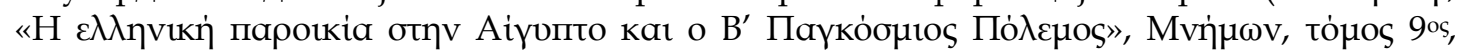

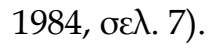

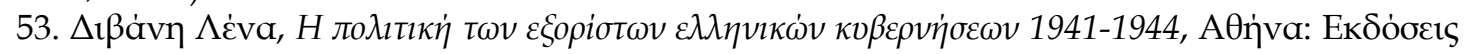

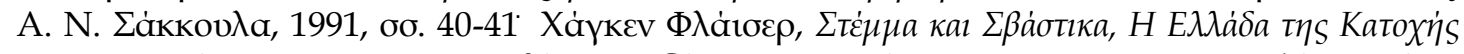

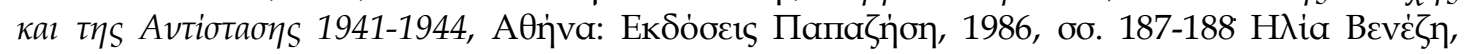


Рекс Липер, иначе упућен као дипломатски представник 1943. године у избегличку Грчку владу, „док је Грчка влада имала седиште у Лондону, у мирним условима који је Лондон пружао у ратном периоду, није имала никакав додир са тим шта се дешавало у својој земљи“54. Целокупна комуникација са Грчком је била проверавана од стране британске службе, која је држала Грке необавештене с изговором да се садржаји „који имају везе са деловањем британских официра у Грчкој... сматрају оперативним и према томе тајним“ ${ }^{\prime 5}$.

И влада и Краљ у почетку су сматрали повољним решење Лондона и нису у томе видели неки нарочит проблем. Оно што је карактеристично за њихов спокој је да су, за време њиховог боравка на Криту, одбили понуду генерала Билија Донована, челника америчке тајне службе O.S.S., да користе заједничку мрежу информација паралелно са британском. Цудерос је одбио ту понуду, прибојавајући се да ће британске службе то протумачити као да гест неповерења. Касније, када су полако почеле да се догађају контрадикторне активности Енглеза у Грчкој и на Средњем Истоку, а дешавало се често да избегличка влада не зна за развој догађаја одлучујућих за њене будуће походе, почела је да буде сумњичава и резервисана према британским службама, нарочито војним ${ }^{56}$.

С обзиром на чињенице, њихова филозофија је свакако остала непромењена. Цудерос је саопштио, у једној врсти саветног писма

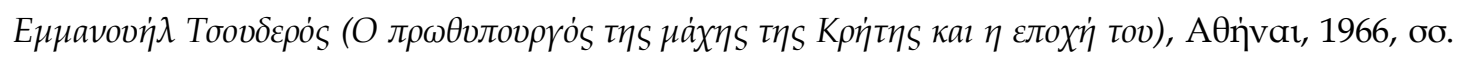
246-248.

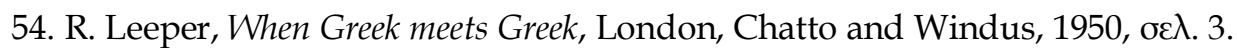

55. R. Leeper, When Greek meets Greek, London, Chatto and Windus, 1950, p. 12, R. Clogg, «Greek government in exile», International History Review, July 1979, p. 390. Канелопулос је био једини грчки политичар који је имао нека сазнања о британским активностима у Грчкој. Влада нигде не приказује да је званично обавештена о подухватима британских офцира у Грчкој, чак ни о мисији коју је предводио Е. Мајерс и Ц. М. Вудхаус с циљем разарања Горгопотамоса.

56. F.O. 371, R 5809/40/19. Наводе се Георгиосова сведочења за мрачна и неконтролисана деловања тајних британских служби на Средњем Истоку и за грчко одељење ВBC-а. За све време прогонства Георгиос тврди да су му радо станице биле сумњиве и да су спроводиле интензивну комунистичку пропаганду. С времена на време преко Форин офиса изазива напетост и тежи ка свргавању највећих демократа, као што је био Сотиријадис. 
упућене потпредседнику тадашње владе П. Канелопулосу, његово мишљење о изјавама Енглеза о независности Албаније, које су дотицале права Грчке над Северним Епиру: „Неко стварно треба имати јак желудац да свари необјашњиве и јадне подухвате наших великих савезника“ 57 . Међутим, колико год су била непријатна ова догађања, нису била довољна да изазову реакцију Краља Георгиоса и Цудероса.

Британци су били ти који су први схватили, у духу њихове политике, да Краљ обавезно треба да се врати у Грчку након ослобођења и да природно седиште Грчке владе треба да буде Блиски Исток, а не Лондон. Да би остварили политику «selling the king to his people» сматрали су да треба урадити следеће две ствари - убедити Грчку владу да разреши уставни проблем и да потврди да ће Грчка имати уставотворну владу после рата, и убедити Краља и Цудероса да посете Средњи Исток, да дођу у контакт са грчком војском и грчким заједницама и да одлучно дају до знања широј јавности да постоје и делују у регији близу Грчке ${ }^{58}$.

Извештаји и коментари ове врсте постоје у изобиљу у службеним записима Форин офиса, започињући нешто након лоцирања владе у Лондону, септембра 1941. године ${ }^{59}$. Цудерос и Краљ Георгиос су тек након озбиљних немира у војсци, марта 1943. године, били убеђени да је њихово присуство у Каиру неопходно. Краљ Георгиос је сматрао да би његове задатке боље и ефикасније извршавали његови пријатељи Британци до њега самог. Липер бележи следеће: „Његово дивљење и приврженост Черчилу је била веома јака, а такође је имао и пуно поверења у Идена. Дошао је у Каиро зато што су га они посаветовали да

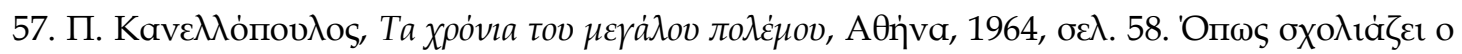

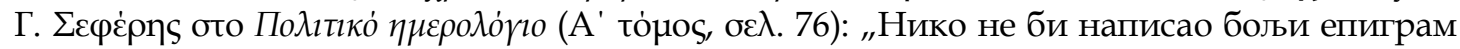
о нашој несрећи".

58. F.O. 371/33187, R 2887.

59. Чак и нешто раније су се појавили слични проблеми. Види показни материјал F.O. 371/29817, R 8633. 
то уради. Послушавши овај савет, сматрао је да је имао отворена врата за ужу сарадњу са тамошњим британским властима“60.

У почетку се чинило да Цудерос не придаје велики значај организацији војске која је сачувана са циљем да учествује у рату на страни савезника. Сматрао је да је Грчка властитим снагама извршила свој задатак, и да од сада па надаље, треба само да чека крај рата и победу савезника да би убрала плодове, који јој по праву припадају. Добро је знао да сам није представљао ни једну страну политичког света и да су све политичке вође биле незадовољне методама које је користио да би подалеко задржао сваку могућу претњу. Краљ Георгиос је био најбоља карта коју је могао да одигра у том тренутку, знајући поверење Британаца у Краља. У његовом писму Идену, 18. октобра 1941. године, пишући о ситуацији политичких странака у Грчкој која је била под опсадом, поновио је и нагласио да „повратак Краља и његове породице у нашу земљу представља питање части, јер се водио правилном и честитом политиком, а и зато што је то било и у нашем интересу, и у интересу наших савезника. Питање династије, која је створена одмах после рата упустила је Грчку у сукоб и анархију без краја“б1.

Будући убеђен да би само бранећи Краља могао да се у ослобођену Грчку врати као премијер, захваљујући недостатку другог политичког или ослонца у људству, веома рано почиње да осујећује чисту демократију, одмах затим и изборе од којих није очекивао позитиван исход: „Зато што избори не могу да се одрже, нити је то дозвољено да се спроведе одмах након дизања прашине која се још увек није слегла... Поред тога ћу изразити још једно своје мишљењење, јасно и искрено. Пошто сам пристаник слободне политичке воље и заступничког метода, захтевам да се у интересу државе не враћамо на

60. R. Leeper, When Greek meets Greek, London, Chatto and Windus, 1950, p. 7. Цудерос му осим тога наглашава идеју да прво ситуација треба да се стабилизује и после да сви оду

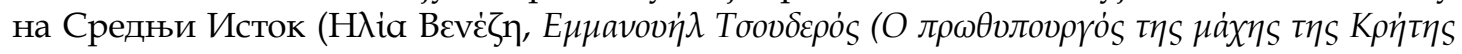

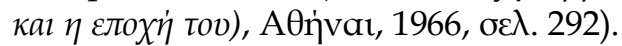

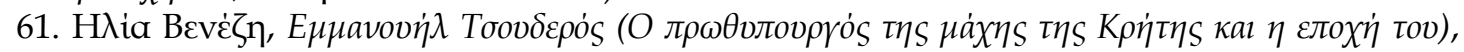

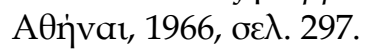


парламентарни систем, то јест на зависност владе од ексцентричне скупштине“62.

Није, дакле, постојао ни један разлог због кога би премијер избегличке владе журио да промени седиште владе или да бар посети Блиски Исток, пошто није имао шта да очекује од грчког народа. С обзиром да је био у Лондону, било му је лакше да одржава везе са грчким Краљем и британским министарством спољних послова, који су му били главне узданице. Како не би било неспоразума, одмах је постало сасвим јасно да се то приписивало као помоћ британских служби: „Осим тога, то не значи уплитање било које ваше службе у наше случајеве када се позива од стране Краља и његове законске одговорне владе да нам помогне у томе. Немојте да заборавите да смо држава без територије и средстава. Пошто смо у таквој ситуацији и налазимо се у вашој земљи, где нам је дозвољено да имамо наше седиште и да негујемо политичку моћ, сматрам да би требало да можемо уз вашу сагласност, да користимо ваше службе, као наше, као замену за наше које нам недостају. Зато се било која ваша активност у унутрашњим грчким проблемима сматра лошим као посредовање, када вам ми то тражимо“63. Цудерос легализује сваку посредничку политику британских служби и пре него што се укаже потреба за интервенисањем, очигледно подстакнут снажном политичком али и личном несигурношћу ${ }^{64}$

62. У Цудеросовом писму упућено Идену из 18. октобра 1941. године “о партијама у Грчкој и мишљењу јавног мњења“" где су веома карактеристични Цудеросови методи, у политичким партијама где се прибрајају непоштовање, искоришћавање народа, међусобна патња и многе друге ствари. Политичке вође су биле сасвим у праву то што су били сумњичави према Цудеросовим подухватима то их је од давнина очигледно

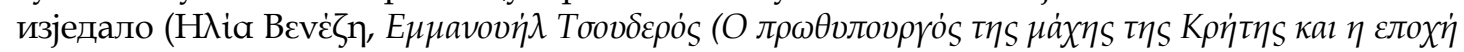
tov), AӨற்val, 1966, oo. 294-298).

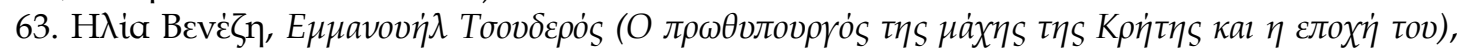

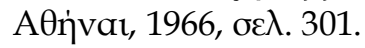

64. Његова упорност је била толико велика где Диксон 28. октобра 1941. године описује његови одбојност према Цудеросовој манији да убедљиво тражи савете за унутрашње грчке проблеме на Средњем Истоку, посебно од Себастијана који му је сасвим веровао (F.O. 371, R 9591/9/19). Најзад је успео да оствари комуникацију са Себастијаном на Средњем Истоку, који је био овлашћен од стране Форин офиса да му лично даје савете за тамошње грчке проблеме, а да за то не зна остатак владе. То је био разлог зашто није хтео да комуницира са њим преко Грчке амбасаде, већ преко Форин офиса (F.O. R $8752 / 9 / 19)$. 
У посебним условима деловања сваке избегличке владе постоји један високи степен зависности од земље домаћина, који је и очекиван. Међутим, у случају првог грчког премијера у избеглиштву примећујемо једну тоталну зависност, колико год да се она често вешто прерушава у политички реализам. Пример П. Канелопулоса, који је стигао на Средњи Исток из окупиране Грчке у пролеће 1942. године да готово одмах предузме потпредседништво владе и оружане снаге, доказује да су постојале неизменичне могућности у постојећем оквиру. Упркос чињеници да је Канелопулос тада био млад, имао је иза себе војно искуство као борац у Албанији и вођа једне мале либералне партије. Преузео је положај имајући многе амбициозне планове деловања. Поред покушаја реорганзације оружаних снага, покушао је да оснује обавештајну службу заједно са капетаном Кортесисом, потпуковником Даскаролисом и потпуковником ратног ваздухопловства Александрисом ${ }^{65}$. Циљ обавештајне службе би био координација напора Грчке са ратним деловањем на Средњем Истоку. Најзад је успео да постигне формирање једног мешовитог грчко - британског комитета који се састојао од истог, Максвела (касније лорда Глеконера, одговорног за реализацију тајног рата) и Хопкинсона. Комитет би пратио и координирао борбу у окупираној Грчкојбб. Канелопулосу су даване гаранције да се ништа неће одлучити у вези са Грчком без његове сагласности и да ће му бити обезбеђена сва средства потребна за комуникацију са Грчком ${ }^{67}$.

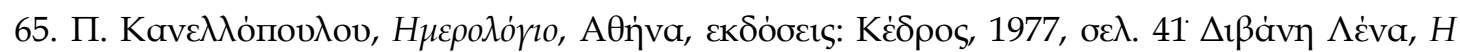

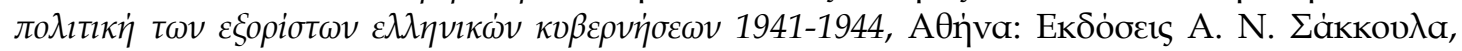

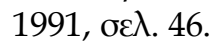

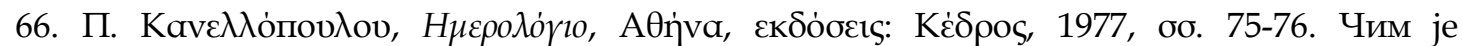
прихватио свој положај потпредседник је признао комитет састављен од пет пуковника

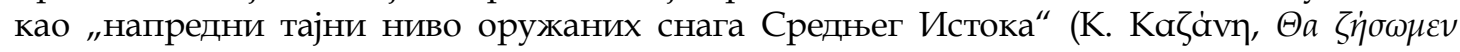

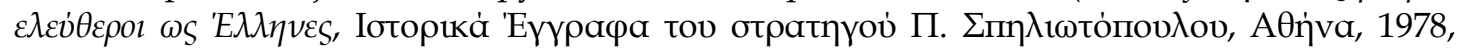

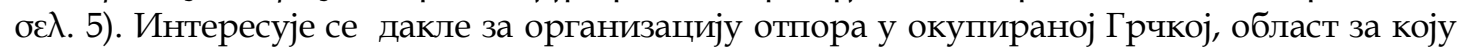
су Цудерос и краљ били незаинтересовани.

67. $\Delta$ ı

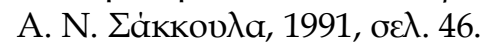


Карактеристичан је био његов став када је објављен британски исказ о независности Албаније. Премијеру и Енглезима је било потребно доста труда да се убеди Канелопулос да не да оставку, сматрајући да се Грчка, и њена битка потцењују, од стране савезника зарад неких других интереса. Насупрот томе, Цудерос је разговарао са британским службама да пронађу заједно начин да умире узрујаног Канелопулоса ${ }^{68}$. Дакле, ни идеолог попут Канелопулоса на месту потпредседник владе, није имао много користи на крају. Мешовити грчко - југословенски комитет није заседао више од осам пута и за циљ је имао више да умири Канелопулосов неспокој, него да формира заиста један успешан владајући орган. Овај комитет није више никада заседао након оставке њеног покретача, јер ниједна страна није стремила ка томе. И у случају Албаније није имао много користи, осим једног Иденовог усменог тврђења да грчке тежње не трпе у области ни једну неизвесну детаљну изјаву за коју се претпоставља да би разјаснила сумње ${ }^{69}$. Међутим Канелопулосов став је одавао једну размеру поређења компромисне филозофије „јаког стомака“ његовог премијера. Такође је предочио потенцијалне користи које би имали у оквирима делимично независне политике, ако би то био усклађен израз политичке тежње целе Грчке владе ${ }^{70}$.

Један други важан чинилац зависности биле су и економске тешкоће избегличке владе. Када је Грчка ушла у рат није потписан

68. Цудероса је, иако га је сам изабрао да му буде сарадник, јако често поткопавала сумња индиректно код Енглеза због антикраљевских убеђења, незрелости итд. Све то је радио зато што је британска штампа и стручне британске службе имале јако добре утиске о њему. Сматрали су га да је „интересантна психолошка веза између окупиране Грчке и владе у емиграцији“. Због тога „иако је имао најлевичарскије идеје од остатака владе... подржаћемо га зато што је чини више делегатском“" (F.O. 371, R 5766/40/G).

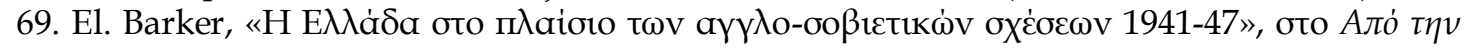

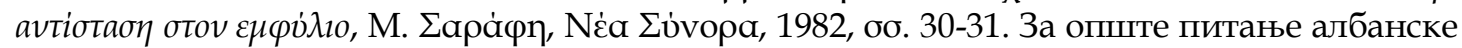

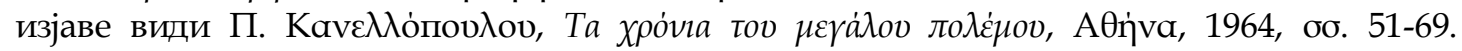
Канелопулос је одувек веровао да је његово снажно противљење у вези са изјавом Енглеза представљало један од основних разлога његовог каснијег пада.

70. $\Delta$ ı

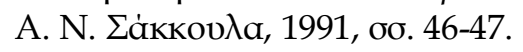


никакав споразум ${ }^{71}$. Након избијања грчко-италијанског рата, Велика Британија преузела је војне трошкове дајући месечно суму од пет милиона лира. Ова помоћ престала је премештањем владе на Крит. Тако су скоро једини економски извори владе у годинама рата биле наплате од изнајмљивања грчке трговинске флоте Британцима. Овде треба да подвучемо да Цудеросова влада није успела да на задовољавајући начин преговара о питању грчке трговачке флоте, која је тада Британији била преко потребна.

Доказ британског интересовања је то да, чим се сазнало о намери С. Теофандиса, тадашњег министра морнарице, да ће путовати у Њујорк да доведе у ред неке нејасноће, покренуле су се британске службе у Лондону и на Средњем Истоку, покушавајући да га убеде да дође прво у Лондон како би се консултовао са њима. Теофанидис се постарао да их умири изјављујући да никада не би доносио било какве одлуке које се не би допале Енглезима и да је једноставно циљ његовог путовања био да поново успостави контакт са личностима из морнарице у Њујорку и регулисање рада тамошњег грчког морнаричког одбора. Посебно је нагласио да овај комитет ни у ком случају не прети британским интересима ${ }^{72}$. Теофанидисове изјаве нису умирили Форин офис, који је наставио да врши притисак да искључиво осигура грчку трговинску флоту и са веома интересантним условима. Наравно да су се побринули да у корист грчких бродовласника реше један осигуравајући законски проблем, како би придобили њихову наклоност ${ }^{73}$. Ыихови притисци су уродили плодом и Грци су уступили Британији скоро читаву своју флоту. Разлози су с једне стране били журба да зараде лак новац од најма, а са друге њихова немогућност да се одупру британским притисцима, с обзиром да је оно што су пре свега желели била британска наклоност ${ }^{74}$.

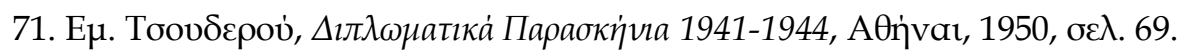

72. F.O. 371/29246, W 7966, W 8313, W 8992.

73. F.O. $371 / 29246, W 8655$.

74. F.O. $371 / 29246, \mathrm{~W} 8655$. 
Најоштрији проблем који је требало да се директно реши било је покривање трошкова војске на Блиском Истоку. Једина помоћ коју је Британија прихватала да пружи била је у виду ратног материјала и намирница за опстанак војске. Што се тиче задовољења других потреба, предложена је употреба износа који су били дати Грчкој као врста ратног кредита. Влада је, супротно томе, сматрала да мора да сачува овај износ у лирама да би намирила своје прве послератне потребе, за које се очекивало да буду веома велике након скорашњег холокауста75.

Засигурно, оружане снаге нису биле једине које је требало одржати. Постојао је огроман проблем снабдевања храном, трошкови функционисања неразвијене јавне управе и издаци издржавања избеглица, који су се након завршетка рата углавном са острва и из Тракије запутиле на Блиски Исток и Африку. Њихов број се кретао на око 15.000 људи и подељени су по касарнама ${ }^{76}$. Грчка влада је имала трошкове за храну све до јуна 1942. године. Затим је то преузела Грчка Ратна Заштита, управа којом су руководиле енглеске службе.

За разрешење ових проблема, да се утврди дакле на својој функцији и да грчко-британске везе добију један конкретан и обавезујући облик, Цудерос је предложио званично склапање савезништва са Енглезима. Војни споразум Британије и Грчке од 9. марта 1942. потврђивао је и формално контролу над грчким оружаним снагама од стране британске војске на Блиском Истоку77. На основу овог споразума, као што наводи Цудерос, Грчка влада је месечно давала Енглеској влади новчану надокнаду коју је ова авансовала за плате

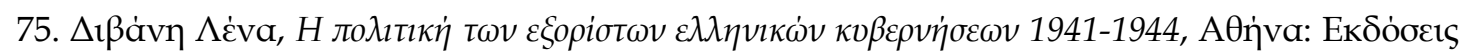

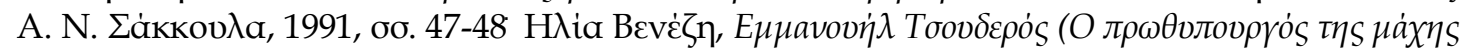

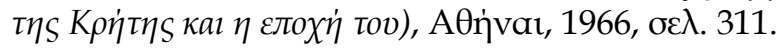

76. Избеглице су постојале у следећим местима: Чесме у Малој Азији, на Кипру, у Халепију у Сирији, у Бејруту у Либану, у Јерусалиму, у Дусерату у Палестини, на Мојсијевим Изворима, у Адис Абеби, Диредава у Етиопији, у Тулубату у Судану, у

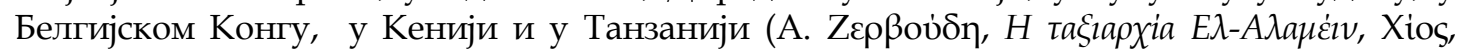
1985, бо. 73-74).

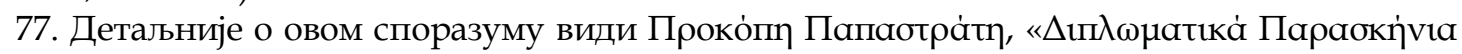

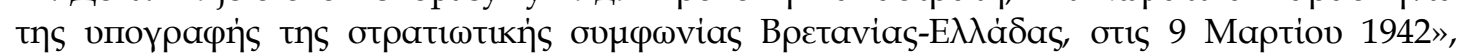

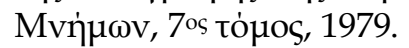


официра и још један мали трошак за њихову исхрану. Остали трошкови су се задуживали на један посебан рачун који је на крају био начињен добротворним према Грчко - британском економском споразуму из $1946^{78}$.

Истовремено, Грчка влада је на свом путовању у САД, јуна 1942. године, искористила прилику да склопи споразум „о најму и зајму“ са Америчком владом. Споразуми овог типа били су први знаци практичне помоћи Рузвелта Черчилу и савезницима ${ }^{79}$. На основу овог споразума, читава количина намирница и лекова који су од тада послати Грчкој, била је неповратна помоћ, као и трошкови путарине приликом превоза житарица из Канаде (после 1943.) и трошкови избеглица на Блиском Истоку и у другим афричким земљама ${ }^{80}$. Тако је решен економски проблем грчке избегличке владе, на један начин који ју је неизбежно обавезао према њеним савезницима, нарочито према Британији.

Анализирајући услове зависности који су ограничавали слободу одлучивања избегличке владе и доприносили њеној неефикасности, треба такође да испитамо у којим је алтернативним центрима власти, мање развијеним или развијеним, могло да се започне независније политичко деловање. Једна могућност која није довољно разматрана, био је покушај грчких власти да развију везе са другим савезничким земљама као противтег њиховој условљавајућој вези са Британијом. Ако изузмемо личне везе Краља Георгиоса са Рузвелтом, током читавог рата нису постојали скоро никакви контакти са САД. Овоме је, наравно, допринела и америчка невољност да се умеша у веома специфичне грчко-битанске везе, али ни грчка страна није ни једном преузела иницијативу да учврсти везе са другом великом савезничком земљом. Насупрот томе, услед путовања Краља Георгиоса и Цудероса у САД, у јуну 1942. године

78. Е

79. О споразумима „о зајму и најму“ и политици Америке види Robert Ferrell, American diplomacy, W. W. Norton and Co, N. York, 1975, oo. 560-566.

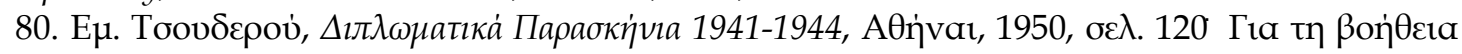

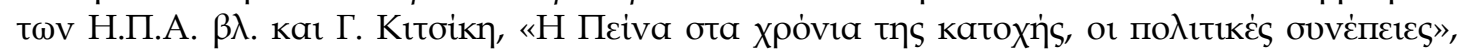

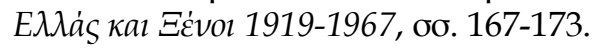


појавила се подозривост и неверица Енглеза, те стога Грци нису ништа покушали ${ }^{81}$. Исти став задржали су и пред Совјетским Савезом, са појачаним страхом због њихове опште резервисаности према режиму ове земље 82 .

Друга могућност избегличке владе која није искоришћена, била је да ојача своју преговарачку функцију, удружујући своје снаге са другим савезничким избегличким владама које су своје седиште имале у Лондону. Уосталом, ово је један од разлога који су довели до тога да британска престоница буде изабрана за стално седиште владе.

Исту замисао имао је и Форин Офис пре него што је стигла Грчка влада, у јулу 1941. Варнер из Доњег Дома предложио је стварање једног органа који би ублажио разлике између избегличких балканских влада у Лондону и који би олакшао њихову комуникацију ${ }^{83}$. Овај предлог није напредовао даље од фебруара наредне године, кад су Пољаци преузели иницијативу да предложе организовање једне сталне комисије, где би се представљале све избегличке владе. У Форин Офису су, иако су знали да су се владе толико разликовале међу собом да не постоји озбиљна опасност да се сложе око једне политике која би била неприхватљива за њих, били забринути да не изгубе утицај над избегличким владама ${ }^{84}$. Цудерос није био одушевљен смелим предлозима Пољске. Он је сматрао да би било боље да се формира саветодавно тело састављено од премијера савезничких земаља у Лондону, које ће се састајати бар сваких десет дана под председништвом Идена у циљу информисања о новостима и размени мишљења о разним идејама. Цудерос је мислио да би се на тај начин придавао већи значај тамошњим владама ${ }^{85}$.

81. Енглези су заиста испитали веома прецизно свако сваки ед-мемоар који су грчки званичници поручили Американцима као и сваку алузију на Кипар и после су их позвали на један вид „одбране“.

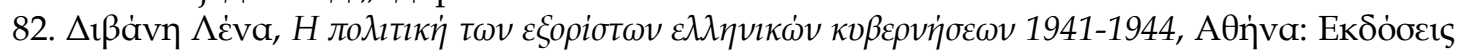

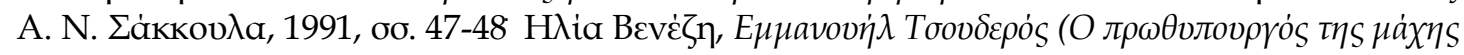

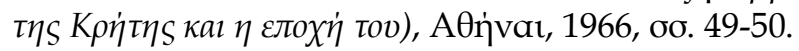

83. F.O. $371 / 29810$, R 6964.

84. F.O. $371 / 30871$, C $1544 / 1543 / 62$.

85. Цудеросов дневник, 10. фебруар 1942. године, састанак са Иденом. 
Из овога се јасно види да је идеја која доминира у глави грчког премијера повећање личног значаја и утицаја, а не суштинска сарадња са осталим његовим колегама. Крајњи исход је био да се усвоји одлука о седмичном састанку председника избегличких влада и петнаестодневном сусрету министара спољних послова који се одржавао у Форин Офису, а којим је предесдавао Иден и који је припремао „Послератну сарадњу за заједничко очување мира“86. Као што се види и из увек неодређеног формулисања предмета ових разговора, вође избегличких влада фокусирали су се на одважне и звучне планове за будућност Европе, занемарујући њену неизвесну и деликатну тренутну ситуацију ${ }^{87}$.

Укратко, можемо рећи да су политичка прошлост владе, која ју је потпуно ускратила за подршку народа, као и сурови услови, који су ограничавали режим рада избегличке владе, у комбинацији са економском и политичком зависношћу, учинили скоро неизбежним уплитање британског чиниоца у унутрашње и спољне грчке послове. Као што је Липер реално формулисао у својим мемоарима: „Ако се размисли о томе да су се грчке оружане снаге сврставале под окриљем британског штаба Средњег Истока, да су све комуникације са грчком ишле преко нас, да је постављена Грчка влада у Египту само захваљујући нашем учтивом посредовању са Египатском владом, да се Грчка влада финансира из британске касе и да ће готово сигурно британска војска да ослободи Грчку од Немаца, сматра се сигурним од стране Грка из свих табора на Средњем Истоку да је Британска влада имала право да обавља пријатељске интервенције које су се тицале грчких проблема“88.

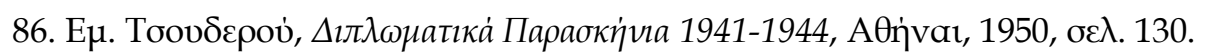

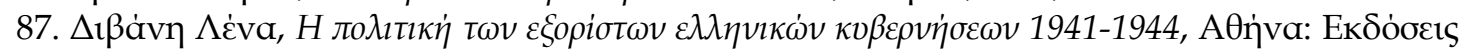

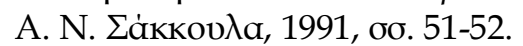

88. R. Leeper, When Greek meets Greek, London, Chatto and Windus, 1950, p. 8. 


\section{ДРУГО ПОГЛАВЉЕ}

\section{НАЦИОНАЛНО-ТЕРИТОРИЈАЛНЕ ПРЕТЕНЗИЈЕ ИЗБЕГЛИЧКЕ ГРЧКЕ ВЛАДЕ}

\section{1 НАЦИОНАЛНО-ТЕРИТОРИЈАЛНЕ ПРЕТЕНЗИЈЕ ИЗБЕГЛИЧКЕ ГРЧКЕ ВЛАДЕ}

Први комплетан попис свих национално-територијалних претензија је био сачињен, а потом представљен Краљу Георгиосу, од стране премијера избегличке владе Цудероса за време путовања у Јужну Африку, крајем јуна 1941. године. Ови захтеви су на неки начин били очигледне и очекиване претензије над територијама насељеним грчким становништвом, као што су Кипар, Додеканез у Егејском мору и Северни Епир. У питању су националне претензије којима Грчка није била у стању да се бави у међуратном периоду, покушавајући да пронађе равнотежу на међународној политичкој сцени, која је била пољуљана после Првог светског рата. О овим територијама и начинима које је изабрала Грчка влада да делује у вези са њиховим послератним присвајањем биће речи детаљније у следећим поглављима.

Списак захтева који је Цудерос предао Краљу Георгиосу био је допуњен са четири претензије, засноване на једној опортунистичкој политици, која је у неким моментима превише оптимистичка и залази у крајност. Први и најлогичнији захтев је био померање граничне линије измећу Грчке и Бугарске. Логика је био да сваки изазивач нереда треба да се онеспособи и да постане немоћан како не би штетио другима. Цудерос је чврсто веровао да је бугарски предлог о аутономији Македоније, тј. стварање једне нове балканске земље, представља само семе раздора свих заинтересованих. Према томе, био је то опасан предлог и требао се избећи. Такође, требало би избећи и један могући савез Јужних Словена (Југославије - Бугарске - Македоније) који би имао за резултат ремећење равнотеже на Балкану. 
Други, помало необичан захтев, је био уређивање граница са Југославијом у корист Грчке. Цудерос је сматрао да безбедност граница Грчке код Ђевђелије спада у надлежност Југославије, а не Грчке, и самим тим може да угрози њену безбедност. Дакле, он је веровао да би једна „праведна савезничка арбитража“ регулисала ову сасвим нелагодну ситуацију.

Трећи захтев се односио на право емиграције и колонизације у бившим непријатељским колонијама Северне Африке, са образложењем да грчке територије нису довољне да снабдеју сво своје становништво. Као што Цудерос пише у својим белешкама: „Постоје Грци који ишчекују да нам буду уступљене садашње италијанске колоније у пределу Северне Африке, као и да нам буде дато право управе других земаља овог континента у којима је остао велики број грчког становништва“. Ове одважне тежње, Цудерос, не само да их не оспорава, већ верује да треба да буду истражене. Овде запажамо да Цудерос није ни једанпут поменуо могућност ових земаља за самоопредељење. Он једноставно предлаже да наставе да управљају овим областима „они који већ познају управљање колонијама“.

Последњи захтев је био прилично хипотетичан. Под предпоставком да ће став Турске према савезницима бити непријатељски, веома оптимистични грчки премијер се надао да претендује на Источну Тракију и признавање Константинопоља као слободне државе, са грчким учешћем у његовој управи и над контролом Босфора ${ }^{89}$.

Цудерос није никада разоткрио ове претензије Британцима, док је неке друге претензије спомињао само у незваничним разговорима. Форин Офис је званично знао за следеће грчке захтеве: непризнавање припајања грчких територија од стране Бугарске, које се догодило за

89. Цео текст меморандума се налази у Досијеу 1 у архиви Цудеросових анекдота у

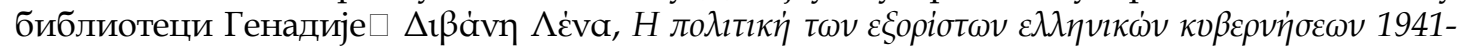

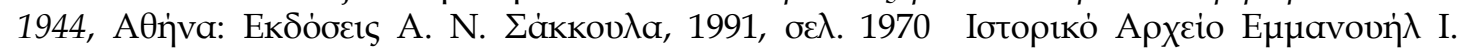

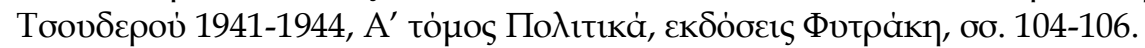


време рата и окупације, без помињања било каквих других претензија од стране Грчке; Северни Епир од Албаније; Додеканез од Италије; учешће у сваком разговору и у свакој одлуци који су били у вези са контролом Босфора и безбедношћу саобраћаја са Источним Медитераном, Егејским и Јадранским морем.

У јулу 1942. године, док су Цудерос и Краљ Георгиос путовали у САД, Форин Офис је с изненађењем сазнао да су грчки званичници презентовали један проширен списак захтева Стејт Дипартменту и Рузвелту. Разлике су постојале у следећим деловима: званично се поменуо Кипар, о којем се Грци нису усудили да разговарају са Британцима; што се тиче Бугарске, прешли су на захтев припајања њеног југозападног дела, тако да би граница била што безбеднија, дакле тачно као што је Цудерос то формулисао 1941. године у свом допису који је био упућен Краљу Георгиосу; од Југославије су захтевали неке исправке које су се тицале граница; и насељавање Грка у Либију. Ово последње је било схваћено од стране Британаца да води ка „стратешки бољим границама“, док се Американцима чинило да је то због економске стабилности Грчке ${ }^{90}$. Што се тицало претензија према Турској, оне се нису излагале ни Британцима, ни Американцима. Ово се вероватно објашњава тиме што је Турска у периоду рата према савезницима имала више један променљив и неодлучан став него непријатељски ${ }^{91}$.

У наредним поглављима ћемо детаљније истражити националне захтеве Грчке владе у емиграцији, који произилазе из дописа, научних радова, мишљења, цитата из докумената Историјског Архива Министарства иностраних послова и Генералног Архива Државе. На крају ћемо видети очекивања Грчке владе у емиграцији у вези са грчким захтевима које ће изложити на Мировном споразуму.

90. Поређење су направили Енглези (F.O. 371/33205, R 4347).

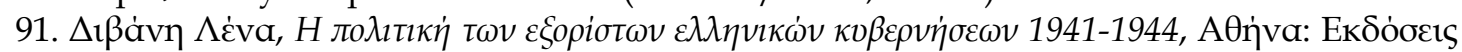

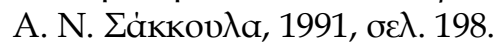




\section{2 ДОКУМЕНТ О ГРЧКИМ НАЦИОНАЛНИМ ПРЕТЕНЗИЈАМА}

У овом поглављу представљен је документ који је објављен од стране Генералштаба грчке војске у Каиру 30. јула 1943. године. Документ је упућен грчким властима и има за циљ обавештавање о тренутној ситуацији на међународној сцени која се тиче грчких националних претензија. Такође дати су и предлози Генералштаба војске о будућим корацима и циљевима грчке спољне политике на Балкану.

„Према предвиђањима долазећих догађаја, који ће да изнесу на видело питање могућег преузимања територија, мислимо да је пожељно да Вам изнесемо мишљење Генералштаба војске, које уопште нема за циљ повећање територија, већ оснаживање граница, које је неопходно само из географских и војних разлога.

Ово питање потребно је решити већ сада, зато што би у случају примирја требало захтевати хитно измештање непријатељске војске са спорне територије и много брже преузимање грчке војске, барем на одређено време до коначне одлуке одбора за мир.

Наравно, само влада је овлашћена да одлучује да ли постоји могућност за преузимање територије, с тим да сматрамо да оснаживање граница није ништа мање важно, пошто из различитих разлога постојеће границе на северу у периоду од 1913. године до 1920. године нису добро обезбеђивале линију раздвајања“92.

Што се тиче питања граница према Бугарској Генералштаб грчке војске верује да рукавац западне Тракије не може да остане какав је данас ако Грчка хоће да обезбеди заједнички осећај сигурности код људи овог дела грчке територије. Природна граница западне Тракије на северу је долина реке Арде, која само може да пружи основну сигурност једној железничкој прузи и луци Александропоља.

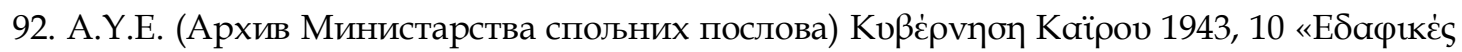

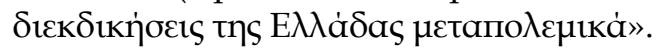


Када је 1919. године Грчка влада желела да граница буде река Арде, Велике силе су одрично одговориле да долине не могу да раздвоје, пошто села са две стране реке имају заједничке трговинске односе и заједничке економске интересе.

„Данас заступамо тезу потребе добијања северног подножја Родопа. Као снажан аргумент, осим етнолошких (Помаки) и историјских чињеница (источна Румелија), који нису у нашој надлежности, представљамо озбиљну потребу за пружање сигурности железничкој прузи и луци Александропоља. Данашња граница је линија 2174-18941592-1482-1259 Алепохори - Свиленград“. Ова линија не залази дубоко, већ се спушта остављајући без заштите целу западну Тракију, нарочито у региону Комотинија, док не постоји ниједна друга линија раздвајања у овом региону. Природна граница 2174 наставља се током реке Арде, а одбрана ове реке због брзине кретања возила мора да буде на северном брегу реке, или конкретније на линији 2174-2001-800 Стамболово Свиленград“93.

Генералштаб грчке војске верује да исцртавање границе на реци Арди у западној Тракији, мора да се прихвати само у случају потпуне и беспоговорне немогућности да се преузме северно подножје Родопа. Такође, у области источне Македоније, конкретније у долини река Нестоса и Стримонаса, мора да повећа границу према региону планина Родопи и Огразден, само из разлога војне сигурности, како је било до рата, значи на врху линије које раздваја воду Родопа, пошто у супротном Грчка се налази у потпуно несигурној позицији. Подржавање граница у линији раздвајања воде је потпуно неодрживо. Долина реке Струмице у комбинацији са долином реке Аксиоса представља један од најбитнијих праваца продора ка долини Солуна.

Ако грчке границе буду постављене северније од данашње границе:

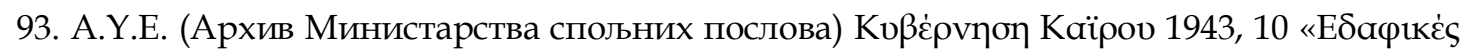

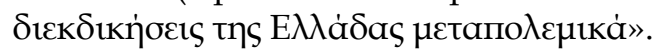


1) Обезбедиће се довољно покривање железничке пруге Солун - Драма, која се данас налази на видном месту за пуцање топа из Велеса.

2) Повећава се дубина покривања долине Солуна имајући најмање три линије разграничења у региону Велеса.

„Да је грчка граница била тамо где данас захтевамо, одбрана Велеса би била јака и не би био остварен толико брзи продор немачке војске кроз долине Струмице и Велеса“.

„Схватамо да је позиција Грчке владе тешка да би поставила питање промене граница са Југославијом, али указана прилика је јединствена и не можемо да је оставимо неискоришћеном. Позиција Грчке треба да се схвати са предношћу у односу на Југославију због много жртава које је поднела и тешко је да се у будућности укаже тако добра прилика да успемо у проширењу граница са Југославијом“ 94.

Граница са Југославијом постављена је 1913. године након притиска бугарских напада и Грчка је била принуђена да је прихвати. Ни после рата који је трајао од 1914 - 1918. године Грчка влада није могла да их побољша, због улоге коју је тада одиграла Србија у европском рату, за разлику од Грчке која је ушла у рат са стране Савезника касно и после устанка.

Према садашњем изгледу граница Солун није нимало сигуран пошто растојање није веће од 70 километара, а у западној Македонији целокупан регион Флорине мора да се исели пошто је једина линија одбране у овој области језеро Вергоритис 1009-Антартикон-Мала Преспа. Са севера се најближи правци према Солуну и Флорини секу у уском теснацу Бабуна, тамо где је и права граница са Југославијом. Због тога што је 1941. године, кад су немачке трупе стигле у уски теснац Бабуна, грчки Генералштаб наредио моментално исељавање другог регулаторског центра Флорине према Јанини, с обзиром да се Флорина налази у истој области са Битољем и Прилепом.

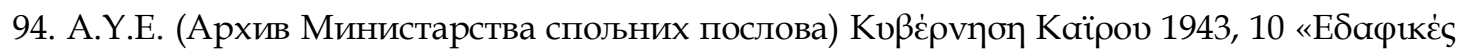

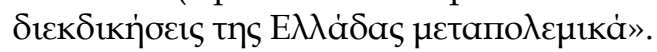


Линија према западу је 1774-1152-Грашко-Бабуна-Крушево-1909Охридско језеро. Овакво исцртавање граница са Југославијом у потпуности и трајно је обезбедило целокупно поље централне Македоније, које представља суштинску везу са Солунским заливом, који има веома важан стратешки значај за целокупно Балканско полуострво до пута Козани - Лариса. Стратешки значај ове везе превазилази оквире Грчке, али и целокупног Балканског полуострва и улази у оквир стратешке политике Уједињених нација.

Са оваквим исцртавањем граница ова стратешка веза Солунског залива има само три природна улаза са севера који омогућавају лаку одбрану. Они су:

1) Теснац Кресне и Рупела у долини Струмице.

2) Косторино (Дојрани).

3) Теснац Бабуна у долини реке Аксиоса.

„Ако буде немогућно северно исцртавање граница, само тада и као најмања граница може да се прихвати јужније исцртавање граница, које са једне стране даје линију одбране Солуна, али са друге стране оставља незаштићен правац за Флорину као и пре. Као што је горе приказано и са основом историје која учи да увек са севера и североистока прети опасност, а никада са југа (и од стране Грчке), могуће је о овом питању разговарати и да исход буде позитиван по Грчку, а Југославија може да буде обештећена узимањем територије Бугарске, северних земаља и Албаније “95.

Што се тиче питања граница са Албанијом жеље Грчке су већ познате и у појединим деловима препознатљиве у међународним оквирима. Уколико је могуће непостојање албанске државе, Генералштаб грчке војске верује да грчка граница треба да прати ток реке Скуби и да садрже планину Мали Себеник (висина 2010 метара).

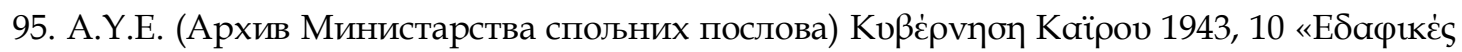

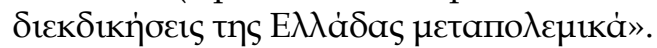


Што се тиче питања Додеканеза, несумњиво је да се не доводи у питање грчке преузимање и, кроз међународне споразуме, признавање грчких острва Додеканеза (споразум Венизелос - Титони). Једино питање које може да се појави и вероватно ће бити потребно да се оповргне претензија Турске владе за преузимање острва која се налазе баш близу обале Мале Азије, острво Сими, Кастелоризо и Кос. Генералштаб грчке војске верује да због права првенства и народности оваква турска претензија не може да буде прихваћена. Грчка страна неће да представи политичке аргументе да оповргне турске аргументе војног значаја, али не може да заборави да ће остваривање таквих турских претензија за последицу имати да се непоправљиво наруши грчко-турско пријатељство, које је већ озбиљно нарушено због протеривања становништва Цариграда, пошто ће тако бити приказано стално давање са стране Грчке и подржавање таквог пријатељства искључиво грчким жртвовањима. Генералштаб грчке војске верује да у случају озбиљне противакције Грчка не би требало да одустане од прихватања да ова острва дођу у њеној превласт као што је раније било на Самосу, а опет постоји оклевање и могућ је пристанак само уз успех политичке размене, примера ради, олакшавање животних услова грчке популације у Турској држави. У сваком случају Грчка страна може да заузврат препоручи да ова острва остану небрањена.

Што се тиче питања Кипра Генералштаб војске нема да изложи мишљење. Уколико је могуће питање предаје острва везано за предају морске и авионске базе не постоји никаква задршка у прихватању.

У случају да услед развијања околности од војног и политичког значаја, дође до ризичног суочавања са бугарским проблемом, уз заједнички споразум или слагање Грчке - Југославије - Турске и Уједињених нација да се Бугарска окружи у границама старе Бугарске краљевине, као што је било пре почетка преузимања суседних територија, тада Генералштаб војске верује да треба правовремено да се 
потпуно преиспитају претходно наведени грчки аргументи што се тиче граница са Бугарском ${ }^{96}$.

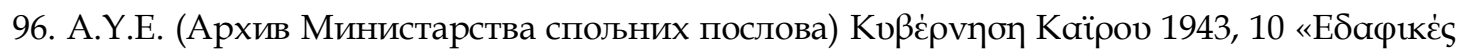

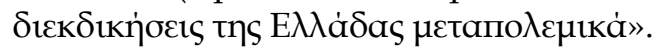




\section{3 ИЗЛАГАЊЕ ГРЧКИХ ПРЕТЕНЗИЈА ВЛАДАМА САД-а И ВЕЛИКЕ БРИТАНИЈЕ}

Грчка влада верује да ће Сједињене Америчке Државе, које су већ показале велику наклоност према борбеном грчком народу, помоћи њему заједно са својим савезником Великом Британијом, тако што ће објединили грчку ослободилачку борбу и што ће му пружити помоћ за остваривање њиховог права у тренутку једног стабилног и праведног мира.

„Признавање грчких права представљало би најснажнију подршку у тешкој борби коју је грчки народ водио против окупатора и глади. Грчки народ је по природи емоционалан, спреман је да све жртвује како би остварио свој циљ у савезничкој идеологији, уколико схвати да ће његово залагање бити у корист Грчке. Непријатељска пропаганда у Грчкој, имајући у виду овакво расположење нације, покушавала да ситним лажима разочара народ, представљајући идеју да ће велики савезници Грчке, у тренутку победе, обратити пажњу само на своје интересе и да ће помоћи Бугарској пребацујући одговорност за њена дела искључиво њеним владарима.

Националне претензије Грчке произишле су из искуства и из поучења савремене историје. Пре свега Грчка жели да се обезбеди како не би поново била жртва инвазије са севера у неком тренутку поновног мећународног усхићења. За само тридесет година Грчка је, без повода, четири пута претрпела овакве нападе 1913, 1916, 1940. и 1941. године. Грчки народ сматра веома погрешним да у периоду мира не придаје значај овим суровим лекцијама из прошлости ${ }^{97}$.

Организација колективне безбедности после рата, као и остваривање Балканске Уније, чији је Грчка била верни следбеник од

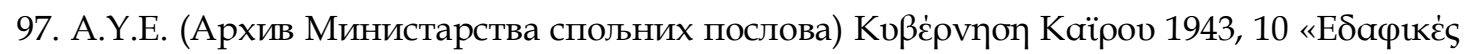

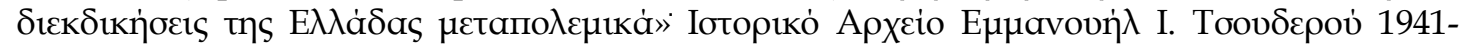

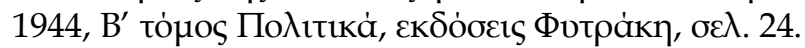


1912. године, наравно да би помогла у отпору против офанзивних акција могућих агресора више него што је то учињено у прошлости. Оваква врста безбедности би се створила више у корист експонираних држава, као што је Грчка, како би се ојачале своју позицију на најбољи могући начин. У суштини, колективна безбедност представља начин одбране од свих врста претњи од стране могућег непријатеља како би се олакшали подухвати међународне помоћи у случају изненадног напада и како би били у могућности да се одбране док та помоћ не пристигне. Ситуација на Балкану у априлу 1941. године била би сасвим другачија да географски услови на грчко - српско - бугарској граници нису олакшали окупаторима да разбију повезаност и сарадњу грчке и југословенске војске у веома кратком временском пероду.“ 98

У наставку, аутори документа сматрају да је неопходно придати значај овим потребама за време уређивања новог територијалног поретка Балкана. Ширење грчких граница североисточно према планинском венцу Родопи и северозападно према Јадранском мору, као у пропорционално уређивање граница са Југославијом би суштински учврстили Грчку и Југославију против сваког напада са Балкана. Јасно је да би јачање Грчке и Југославије било у интересу демократских снага, јер би у могућим међународним кризама ове државе биле на њиховој страни. Истовремено, њихово јачање би поједноставило решење војних и политичких проблема у Југоисточној Европи. Олакшавајућа чињеница је била да су ове територије, у којима би дошло до промена граница, биле области које су окупиране за време Балканских ратова. Становништво ових планинских регија са етнолошког становишта, поред насилних и намерних промена које је наметнуо окупатор, не представља препреку у предложеном уређивању које је у интересу мира балканских народа.

Са друге стране треба истаћи да се једно овакво регулисање ствари на Балкану намеће и из разлога опортунитета политике на вишем нивоу.

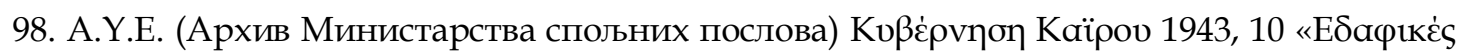

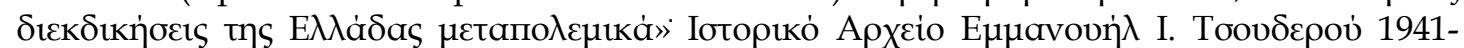
1944, B' тó 
Државе које су изазвале тадашње немире, или оне које су то потпомогле из користољубља или других разлога, треба да сносе последице својих дела. Само такво примерно кажњавање ових земаља може да спречи понављање таквих дешавања у будућности. Ако би ове државе, под изговором да су биле увучене у рат лошим проценама својих владара, задесила иста судбина са њиховим жртвама, то би претстављало веома лош пример за мир и безбедност у будућности. Објективно истраживање у вези са одговорностима ових Балканских држава би показало да су тврдње о неодговорности њихових народа неосноване. Власти су заступале њихову националну вољу, која је одувек подстрекивана суровим расизмом који се учестало испољавао од 1912. године нарушавајући мир на Балканском полуострву. У другачијој ситуацији, ови народи би сигурно нашли начин да се успротиве и да одмах реагују против немачке политике.

Осим граничног уређивања о коме је било говора у претходном тексту, питања која више интересују Грке и која треба да буду објекат старања Грчке владе су Северни Епир, Додеканез, Кипарско питање и питање економске издржљивости Грчке како се не би одмах после рата појавила озбиљна криза због инфлације и недовољне призводње.

Питање Северног Епира и Додеканеза темељно је обрађено у предговору тзв. „Беле Грчке Књиге“ (дипломатски документи о спољној политици Грчке) који се односи на италијански напад на Грчку, објављеној у Лондону. Представљање ових проблема јасно доказује да су и Епир и Додеканез грчке области под непријатељском опсадом већ 22 године, и поред чињенице да су према споразумима припадале Грчкој. Поред историјских и етнолошких права Грка у овим областима, она су призната и низом међународних споразума који се хронолошки могу сврстати у период између 1914. и 1920. године и која су остала неостварена због насилништва Италијана.

Питање Кипра је сасвим другачије природе. Нису у питању ратне претензије, али како би се представила што потпунија слика грчких 
претензија и мишљења у циљу обавештавања Америчке владе, представљало би велики пропуст његово непомињање. „Ово острво је у целини окупирано од стране Велике Британије, као што је то био случај и са Јонским острвима, које је касније Британија предала Грчкој. Британија је 1914. године понудила Кипар Грчкој под условом да Грци ступе на страну савезника у рату. У том тренутку Грчка није прихватила услов, али је касније два пута изашла из неутралности, без постављања услова, свим средствима којима је располагала борила се на страни савезника. По потписивању мира након Првог Светског рата, потписује се посебан споразум између Грчке и Италије у вези са Додеканезом, у коме се спомиње и поновно приступање Кипра и Родоса Грчкој.

Територија острва Кипра је насељена 5/6 грчком популацијом у етничком, верском и језичком смислу. Чињеница да је 1/6 територије покривена турским становништвом не представља разлог да преосталих 5/6 становништва Кипра буде ускраћено за право на самоопредељење.Ток два Светска рата представља доказ да је стратешки значај овог острва много мањи од поморског и стратешког положаја Грчке у Источном Средоземљу. Грчка се два пута сама понудила у периоду оба Светска рата да одигра улогу коју јој намеће историја и њен географски положај. Према томе, уједињење Грчке са свим острвима, где се у сваком погледу јасно препознаје грчко порекло које се не може оповргнути, даје јој велику снагу, али ствара и обавезу да води исту политику према савезницима и у будућности“99.

„Економска издржљивост Грчке је под трајном кризом због планинске природе њених територија и недостатка производње. И поред напорног рада становништва, грчка производња не успева да задовољи потребе државе. Покушај њених становника за самоодрживошћу остаје неостварен због сталног повећања броја становника, услед велике разлике у броју новорођених у односу на број

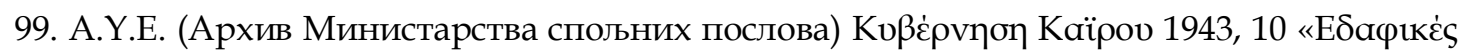

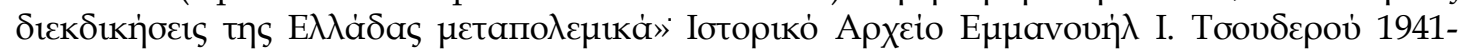

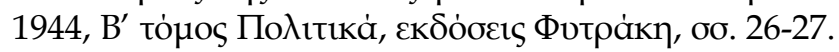


умрлих, посебно за време периода мира. И тако демографски проблем Грчке постаје један од највећих који се јавља у једној европској земљи, што значи да вишак становништва води ка томе да неће бити довољно места унутар постојећих граница и од тог тренутка је требало да се предузму неке мере о њиховом одливу у иностранство. Наравно, да је Источна Тракија тада остала у оквиру Грчке, која је била уступљена истој из разлога што је имала грчки карактер према споразуму из Севра, онда Грчка не би имала овакав проблем. Ова област, богата производњом жита, је могла да обезбеди Грчкој средства за лагодан живот. Према томе, Грчка треба да у периоду мира обезбеди економску постојаност и да у скоријој будућности избегне економско загушење, као и политичке и друштвене немире. Питање емиграције њеног вишка становништва треба да подједнако преокупира владу, као и остала национална питања"100.

Грчка влада не претендује за колонијама како би се суочила са овим проблемом, али верује да земље које су слабо насељене треба да буду признате као државе слободне емиграције и ово право да се уступи и Грцима, којима емиграција не представља политички циљ. Једна од ових области је и Либија, где је Грчка некада имала напредне колоније. Осим тога, проблем миграције народа чије су земље пренасељене у државе које су слабо ненасељене, не представља само случај Грчке. Стабилизација мира ће веома зависити од пажљивог и праведног решавања овог проблема. Савезници не треба да добију само рат, већ и мир.

Грчка влада је забринута и у размишљањима о томе како да се суочи са сложеном економском ситуацијом, која ће одмах након рата да завлада у целој Грчкој. Целокупна економска структура која је постојала пре рата биће уништена. Овај проблем, заједно са хитним питањем снабдевања становништва намирницама, изгледа заиста огроман у

100. А.Ү.Е. (Архив Министарства спољних послова) Коßв́рvұоп Каїроv 1943, 10

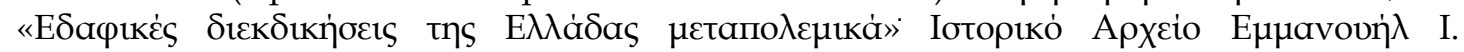

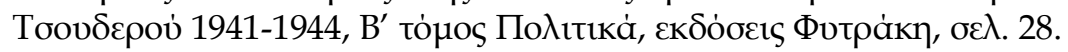


поређењу са малим грчким снагама у погледу производње и средстава. Само солидарношћу великих савезника Грчка може да блоговремено предузме мере за њихово праведно решење. Грчка је држава која може да се искористи као центар операција за акције у Југоисточној Европи и на овај начин ће бити могућ брз проналазак капитала, који је потребан Грчкој за њену економску реорганизацијуำ1.

101. А.Ү.Е. (Архив Министарства спољних послова) Коßв́рvฤоп Кайроv 1943, 10

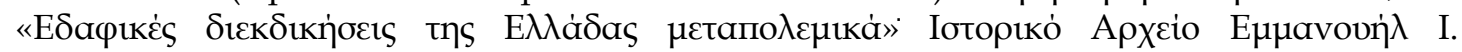

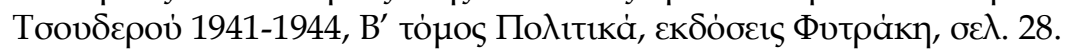




\section{4 РАСПРАВЕ О ГРЧКИМ НАЦИОНАЛНИМ ПРЕТЕНЗИЈАМА}

Грчке националне претензије могу се поделити на три категорије: територијалне, економске и политичке. Политичке претензије се односе на положај Грчке у послератној Европи, а посебно на Балкану, и гаранције политичке природе које ће затражити ради обезбеђивања независности и очувања њеног интегритета и мировног поретка. Допринос Грчке у општем покрету и зрелост које је исказао њен народ према демократским идеалима, слободи и међународној солидарности представљају гаранције за задовољење њених претензија ${ }^{102}$.

У склопу својих територијалних претензија Грчка влада је захтевала: комплетно обнављање државе успостављањем предратних граница, „припајање оних територија на којима вековима преовлађује грчки дух и доминира грчка култура и регулисање северних граница ради обезбеђивања независности и инегритета грчке државе. Грчке територијалне претензије се ослањају на опште прихватљиве принципе са којима постоји потпуна сагласност. Начело самоопредељења народа и право на безбедност представљају основ националних претензија Грчке.“

У документу се наглашава да је зрелост коју је показао грчки народ за време рата треба да буде представљено на најбољи начин на Конференцији мира. Далеко од сваке империјалистичке политике или жеље за осветом, грчки захтеви се заснивају на начелима прихватљивим од стране свих савезника Грчке. Грчкој, као и другим малим државама, је у интересу да поштује међународно право. Недостатак поштовања правних и моралних начела, пре или касније, буде на штету ослабљених држава.

Принцип самоопредељења народа представља једино начело које је признато у међународним односима. Тековине Француске Револуције, након што су потиснуте на Бечком конгресу од стране великих сила тог периода, лагано су преовладавала у Европи путем жестоких борби

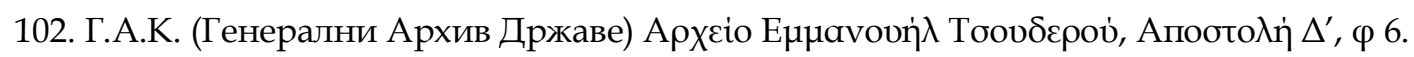


против постојећег режима власти који је био на снази до 1919. године и послужиле су као основа за обнављање Европе. Упркос потешкоћама примене ових начела, посебно у областима у којима постоје више националности или постоји недостатак чисте националне свести, као и чињеница да признавањем само овог начела није довољно да се обезбеди међународни поредак и уклоне супротности међу народима, њихово право на слободно опредељење не долази у питање јер представља једини признати критеријум стварања држава. Атлантска повеља и Молотофова изјашњавања по овом питању представљају још једно признавање овог начела.

Обнављање Грчке са предратним границама се и не доводи у рапсраву из моралних и етнолошких разлога. Заиста би било несхватљиво и неморално да се разговара о интегритету државе која се жртвовала у заједничкој борби, дајући значајан допринос. Шта више, предратне границе Грчке су успостављене под веома неповољним околностима и по споразуму који је Грчка потписала као поражена држава. Имајући то у обзир, нема говора о разматрању грчких предратних граница.

Такође, право самоопредељења народа у потпуности оправдава успостављање предратних грчких граница. Задивљујуће јединство које показује грчки народ, а посебно погранично становништво за време напада представља чврст доказ нациналне свести и духовне повезаности целокупног народа. Мали број земаља може да се похвали толиком етнолошком униформношћу као Грчка. Из званичних списа Лиге народа прилажемо следеће табеле ${ }^{103}$ :

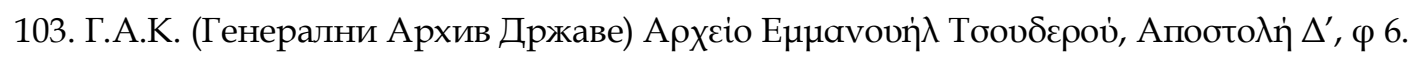




\begin{tabular}{|l|l|l|}
\hline \multicolumn{3}{|c|}{ Грчка 1920. године } \\
\hline Грци & 4.470 .000 & $80,75 \%$ \\
\hline Турци & 770.000 & $13,91 \%$ \\
\hline Бугари & 139.000 & $2,51 \%$ \\
\hline Албанци & 18.000 & $0,32 \%$ \\
\hline Јевреји & 65.000 & $1,17 \%$ \\
\hline Јермени & 1.000 & $0,02 \%$ \\
\hline Разни & 73.000 & $1,32 \%$ \\
\hline Укупно & 5.536 .000 & $100 \%$ \\
\hline
\end{tabular}

\begin{tabular}{|l|l|l|}
\hline \multicolumn{3}{|c|}{ Грчка 1928. године } \\
\hline Грци & 5.822 .000 & $93,83 \%$ \\
\hline Турци & 103.000 & $1,66 \%$ \\
\hline Бугари & 82.000 & $1,32 \%$ \\
\hline Албанци & 20.000 & $0,32 \%$ \\
\hline Јевреји & 70.000 & $1,13 \%$ \\
\hline Јермени & 35.000 & $0,56 \%$ \\
\hline Разни & 73.000 & $1,18 \%$ \\
\hline Укупно & 6.205 .000 & $100 \%$ \\
\hline
\end{tabular}

Према званичним статистикама грчке владе 93,83\% становника Грчке представљају Грци, и ова униформност обезбеђује, на основу начела народности, потпуно обнављање предратних граница, нарочито у областима Македоније и Западне Тракије, које су тада биле под окупацијом Бугара. Све и да се занемаре историјске, етнолошке и геоекономске чињенице који у потпуности легализују грчки суверенитет, ниједан бугарски захтев не може да буде прихваћен зато што већ од почетка присутва Бугара на овим пределима, они представљају незначајну мањину. Бројке у следећим табелама представљају званичне податке грчке владе који су прикупљени у Грчкој за време окупације. Након потписивања споразума Политис-Калвов 29. 
августа 1924. године, сви становници јужнословенског порекла грчке области Македонија пописани су као Бугари.

\begin{tabular}{|l|l|l|}
\hline \multicolumn{3}{|c|}{ Македонија 1912. године } \\
\hline Грци & 1.513 .000 & $42,6 \%$ \\
\hline Муслимани & 475.000 & $39,4 \%$ \\
\hline Бугари & 119.000 & $9,9 \%$ \\
\hline Разни & 98.000 & $8,1 \%$ \\
\hline Укупно & 1.205 .000 & $100 \%$ \\
\hline
\end{tabular}

\begin{tabular}{|l|l|l|}
\hline \multicolumn{3}{|c|}{ Македонија 1926. године } \\
\hline Грци & 1.341 .000 & $88,8 \%$ \\
\hline Муслимани & 2.000 & $0,1 \%$ \\
\hline Бугари & 77.000 & $5,1 \%$ \\
\hline Разни & 91.000 & $6 \%$ \\
\hline Укупно & 1.511 .000 & $100 \%$ \\
\hline
\end{tabular}

\begin{tabular}{|l|l|}
\hline \multicolumn{2}{|c|}{ Западна Тракија 1940. године } \\
\hline Грци & 232.000 \\
\hline Турци & 100.000 \\
\hline Помаци и разни & 13.000 \\
\hline Укупно & 345.000 \\
\hline
\end{tabular}

Из горе наведених званичних података проистиче да су Бугари у периоду туркократије бројали 9,9\% од целокупног становништва Македоније, а 1926. године их је било 5,1\%. Смештање избеглица из Мале Азије није уопште утицало на измену састава становништва Македоније што се тиче Бугара. Промена је произашла из принудне размене становништва између Грчке и Турске. Смањење броја Бугара за 50.000 се приписује добровољној размени. Дакле, ни један етнолошки састав становништва и пре 1912. године не оправдава бугарске претензије. У 
Западној Тракији не постоје Бугари. Присутна је значајна турска мањина која је изузета из размене, као што су изузети и Грци из Константинопоља. Нешто мало Бугара који су преостали настањују се углавном у централној и западној Македонији, далеко од грчко-бугарске границе. Према чињеницама које је износила грчка влада, бугарски ставови су потпуно неосновани, и ослањају се само на споразум из Светог Стефана који никад није примењен, и на крајње империјалистичким намерама. Такође, није долазила у питање никаква расправа о аутономности грчке Македоније, јер ово питање не само да би било противно самом начелу самоопредељења, већ би имало као последицу стварање једне потпуно вештачке творевине, што би пооштрило разлике и ривалитет међу балканским народима. Аутономност Македоније представља идеју бугарске политике да индиректно задовољи своје претензије. Ово се и потврђује чињеницом да је после освајања грчких и српских територија Македоније од стране Бугара, влада и штампа у Софији са негодовањем одбијала сваки разговор који се односио на аутономност те територије $\mathrm{e}^{104}$.

Да наглашавамо, да је грчко порекло Македоније и Тракије добро познато бугарским освајачима и зато примењују политику која има за циљ истребљење грчког становништва. Прогонства, покољи и насиље над Грцима од стране Бугара, као и групно насељавање бугарског становништва на грчке територије, потврђују грчки елемент у овим областима и апсолутни недостатак политичке зрелости и елементарне хуманости. Став Бугарске ће свакако утицати на карактер и степен гаранција које ће се тражити од ње, и наравно утицаће на њен положај у послератном стању ствари. Грчка је сигурна у своја неопозива права и са задовољством је прихватила уверавања њених великих савезника о интегритету њених предратних граница. Посебно је ценила противљење Совјетског Савеза да обећа Бугарској грчке и српске територије у 
Македонији у замену за њен могући прелаз на страну савезника, чак и у задњем тренутку 105 .

\section{ЕПИР И АЛБАНИЈА}

Грчка влада је од самог почетка свог боравка у иностранству у контактима са савезничким владама потенцирала питање Северног Епира, где је излагала историјска и етнолошка права Грчке над том територијом, као и споразум између ње и Италије још из периода Првог светског рата. Уско повезано са овим је и питање граничне безбедности са територије Албаније, где Грци нису одмах прецизирали до које границе би се пружале њихове претензије на северу. Област Северног Епира представља део грчких националних претензија и у свести грчког народа представља неодвојив комад грчког тла, посебно Епира. Ова област је још у прошлости била насељена грчким становништвом, али и у периоду који истражујемо већински део становништва је грчког порекла. Дакле, припајање северног Епира представља један од најзначајнијих циљева који је грчка избегличка влада заступала у спољној политици.

Ро ставовима грчке владе, разлози на којима се заснива уједињење Северног Епира са Грчком су, пре свега, историјски и етнолошки. Историјски разлози који оправдавају претензије Грчке над Северним Епиром су многобројни. Велике силе су одувек признавале право Грчке над овом територијом, иако се граница између Грчке и Албаније формирала између 1914. и 1925. године на такав начин да је ван граница државе Грчке остало на хиљаде Грка. Овај чин се приписује настојањима Аустрије и Италије које су желеле Албанију као штит и средство којим би покорили Балкан посредством своје владавине на Јадранском мору.

Говорећи о Северном Епиру подразумевамо албанске области Аргирокастра, Корице, Авлоне и Вератија све до реке Скуби. У овим областима северног Епира већ има око пола милиона становника. 
Главни градови су: Аргирокастро са 12.406 становника, Корица са 21.592, Вератио са 8.000, Авлона са 5.942 (попис из 1923. године). Муслимански Албанци представљају половину живља у горе наведеним областима, а хришћани другу половину (у складу са пописом из 1923. године у целој Албанији, хришћана православаца има 168.215 у односу на 529.694 муслимана). Православни хришћани у Северном Епиру представљају већински део становништва у многим областима106.

Грчка сматра албанску државу кривцем због непријатељских подухвата против ње и захтева да се Албанији одреде правила примирја сразмерна онима која ће се одредити и другим пораженим државама. Грчка захтева припајање Северног Епира, тачније области Корице, Аргирокастра, део области Авлоне и острва Сасо. У овим областима је већина становништва била грчке националности до 1913. године, што се потврђује и у званичним документима. У покушају да убеди своје савезнике, осим неоспорних историјских права над овом територијом, Грчка влада је изложила и одређене међународне споразуме: а) Режим аутономије за Северни Епир је признат од стране великих сила - Велике Британије, Франщуске, Русије, Италије, Немачке и Аустроугарске, 1. августа 1914. године у дипломатској ноти упућеној Грчкој влади. б) Споразумом Венизелос - Титони из 29. јула 1919. године Италија се одриче својих претензија над Северним Епиром и преузима обавезу да помогне Грчкој да успе у свом покушају да припоји ову област. в) Меморандум из 9. децембра 1919. године, са потписом представника Велике Британије, САД-а и Француске на Конференцији о миру, који признаје права Грчке над областима Северног Епира. г) Амерички Сенат

\footnotetext{
106. У пописима становништва пре 1920. године смо имали у округу Погонио 5.185 Грка - ниједног Албанца, у Дриинуполију 15.000 хришћана - 11.000 муслимана, У Лембехову 7.500 хришћана - 8.500 муслимана, У Делвиниону 18.000 Грка - 5.000 муслимана, у Тепенелију 6.000 Грка - 7.000 муслимана, у Премети 10.000 Грка - 12.000 муслимана, у Лескови 6.500 Грка - 4.000 муслимана, у Химари у области Авлона 6.188 хришћана 4.460 муслимана. У округу Корице, области Корице 32.873 Грка - 35.807 Муслимана, у Колонији 11.269 Грка - 9.615 Албанаца, у Серајову 326 Грка - 8.262 муслимана (А.Y.Е.

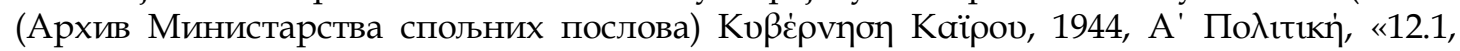

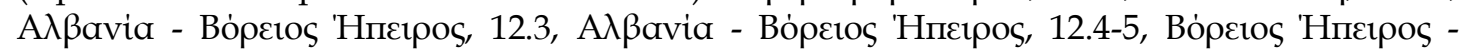

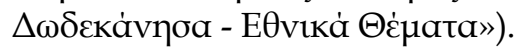


је одобрио припајање Северног Епира Грчкој својом одлуком из 17. маја 1920. године. Италија, будући да се налазила у бољој позицији у односу на неповољан дипломатски положај у којем се нашла Грчка након 1920. Године, успела је да се не изврше горе наведене одлуке.

Иден је, имајући у виду права Грчке над Северним Епиром и након захтева Грчке владе, додао следећу констатацију у својој изјави, из 17. децембра 1942. године у Скупштини Заједница, која се тицала поновног успостављања албанске независности после рата: „Британска влада сматра да питање граница албанске државе треба да се испита на Мировној конференцији“. На овај начин се питање обнове Албаније као независне државе раздвојило од питања њених будућих граница. Када је Иден дао изјаве о независности Албаније дошло је до размене докумената имеђу Грчке владе и Форин Офиса, из којих произилази да изјава Идена није решавала проблем граница, који је остављен да се реши након рата, и да би статус који је имала пре рата Италија према Албанији утемељен на међународним споразумима, после рата преузеле Југославија и Грчка. Тако се није могло порицати право Грчке да се интересује за ову земљу. То је питање за које може да се донесе коначна одлука само после рата ${ }^{107}$.

Веома охрабрујуће уверење, о задовољавајућем решењу питања Северног Епира после рата, је дато усмено Краљу Георгиосу од стране Идена 17. децембра 1942. године, за време њиховог сусрета у Форин Офису. У вези са решењем северноепирског проблема на основу етнолошких критеријума Грчка убудуће захтева да се њене границе са Албанијом одреде на такав начин да јој пружају безбедносну линију одбране. Ако се испуне ови захтеви, Грчка се неће противити очувању Албаније као независне државе, али са енглеском и америчком гаранцијом и заштитом за обнову ове земље и њену заштиту од италијанских интервенција.

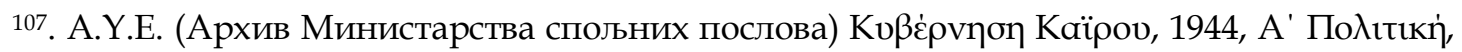
«2.1, A入ßavia». 


\section{ДОДЕКАНЕЗ - КИПАР}

Право самоопредељења народа ће бити признато и становницима острва Егеја и Кипра, који вековима чекају на своју слободу. Национални састав Додеканеза и Кипра се не оспорава ни од кога, тако да њихов боравак ван Грчке представља прекршај начела права нација и приписује се искључиво политичким циљевима и интересима Великих сила.

Додеканез броји 140.000 становника, од којих су више од 120.000 Грци које са остатком Грчке повезује иста крв, порекло, вера, језик, традиција, обичаји, култура. У периоду од три хиљаде година судбина Егејских острва уско је везана је за судбину хеленизма.

Почетком XIII века Додеканез бива освојен од стране Крсташа и од 1537. године пада под власт Отоманског Царства. Народне везе са проширеном аутономијом су остале испоштоване и под римском, и под крсташком управом. Тако је Отоманско Царство уступило посебне повластице које су биле међународно признате од стране Конгреса у Паризу (1936. године) и у Берлину (1878. године).

У периоду Италијанско-турског рата 1911. године, Италијани су заузели острва као ослободиоци и посредством својих званичних представника су изјавили да ће поштовати дуговековне повластице острва и да ће обезбедити њихову независност. Насупрот овим изјавама, италијанска власт је прекршила поштовање међународно признатих привилегија, и применила је мере којима је кршила основна људска и мањинска права. Незаконита италијанска окупација настављена је све до 1924. године.

Пуних петнаест година међународни акти који се тичу Додеканеза су смењивали један други. Споразум из Лозане између Италије и Турске (15. октобра 1914. године) је предвиђао евакуацију острва од стране италијанске војске када Турци напусте Либију. Италија се успротивила да изврши прописани споразумом. Тајни уговор између 
Савезника и Италије (26. априла 1915. године) признавао је италијанску окупацију острва. Овај уговор је престао да важи након уласка САД-а у рат. Споразум Венизелос - Титони (29. јула 1929. године) је признавао грчку превласт над острвима, изузев Родоса који је уживао посебан аутономни режим и његова судбина је уско везана са судбином Кипра. Овај споразум је поништен од стране Италије годину дана након његовог потписивања. Акт Високог Савета Савезника (21. фебруара 1920. године) је признао грчка права која су се тицала Додекаеза. Одлука Сената САД-а је признала грчке претензије над острвима Егејског мора (17. маја 1920. године). Споразумом из Севра (10. августа 1920. године) уступљено је Италији право над Егејским острвима које је до тада имала Турска. Истовремено је Париским споразумом уступљен Додеканез Грчкој, изузимајући Родос за који је предвиђен посебан аутономни статус. Према споразуму био би одржан референдум у року од петнаест година за коначно разрешавање судбине острва, осим у случају да Енглеска раније уступи Кипар Грчкој. Италија се успротивила да призна овај уговор и поништила га је у октобру 1922. године. На конференцији у Лозани (24. јула 1923. године) одређена је судбина Егејских острва њиховим уступањем Италији, и поред изричите опрезности на којој је инсистирало грчко представништво, на коју није дат ниједан одговор, нити је изражено било какво негодовање од стране Италије.

Падом фашистичке Италије неизбежно се опет отвара питање уједињења Додеканеза са Грчком. Међународна заједница је већ стала на страну грчких ставова. Италијанска влада изјавила да Додеканез треба да се одмах врати Грчкој. Министар спољних послова Велике Британије, и поред опште резервисаности према разрешавању територијалних питања још из ратног периода, изразио је своје задовољство за став Италијанске владе по питању Додеканеза. Турска је задовољна због удаљавања Италије, јер је њено присуство представљало сталну опасност, и нада се да ће острва бити препуштена мирољубивој земљи, али под условом њиховог разоружања. 
На Кипру од укупног становништва од 320.000 људи, 80\% су Грци. Њих повезују исте везе са остатком Грчке које повезују и становништво Додеканеза, и њихова историја је нераскидиво повезана са дуговековном историјом хеленизма, све до њиховог поробљавања од стране Отоманског Царства. На заседању у Берлину, 1878. године, призната је енглеска окупација Кипра. Енглеска је 1915. године понудила острво Грчкој у замену за учешће у рату на страни Савезника, док је споразумом у Севру повезано решење питања Кипра са питањем Родоса. После кршења договора од стране Италије, Енглеска је одбила да уступи Кипар. Право самоопредељења народа води ка уједињењу острва са Грчком.

Два проблема је могуће да искрсну, а то су питање турске мањине и стратешки значај Кипра за Велику Британију. Заједнички живот Грка и Турака током векова представља традицију која може да се настави под режимом слободе и постојања закона. Постојање турске мањине на Кипру ће бити под истим режимом под којем се налазе турска мањина у Западној Тракији и грчка мањина у Константинопољу. Што се тиче безбедности Британске Аутократије, могуће је да се на острву очувају војне базе на одрећеним локацијама и под посебним режимом. Заједнички интереси Енглеске и Грчке у Источном Средоземљу представља гаранцију за проналазак задовољавајућег решења које ће бити у складу са правом самоопредељења грчког становништва на Кипру и безбедности Британске Империје $\mathrm{e}^{108}$.

\section{ГРЧКО - БУГАРСКА ГРАНИЦА}

У временском периоду од тридесет година Бугарска је три пута ратовала са својим суседима, и у оба Светска рата била је против слободољубивих и демократских држава. Ова чињеница оправдава недостатак поверења у бугарски народ, што се тиче његовог става у периоду трајања рата, као и политике коју је примењивала његова влада

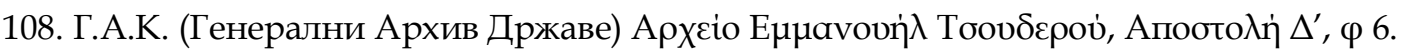


у периоду мира. Никада није искрено прихватила сарадњу са својим суседима, нити је икада потписала било какав мировни споразуму којим би се обезбедио трајни мировни поредак на Балкану (нпр. Балкаски Споразум). Насупрот томе ограничивала се на потписивању билатералних уговора.

У овом делу се испитује питање одговорности Бугарске у рату. У њеном случају намеће се предузимање мера које ће обезбедити интегритет суседних земаља и мир на Балкану. Многи подржавају став да ниједна одговорност не терети бугарски народ за политику његове владе, и да би уклањање са власти тадашњег руководства ослободило бугарски народ сваке одговорности за дешавања у току рата. Чињеница је да многи народи не могу да буду одговорни за све подухвате њихових влада, али и потпуно ослобађање од одговорности се не може увек подржати, нарочито у случају Бугарске. Док год је влада подржана од стране свих националних снага и прати јасну политику против које се не појављује ниједно противљење, значи да су подухвати владе подржани од већине народа и последично је одговорност узајамна. Та узајамна одговорност постаје још већа када се учешће у владиној политици изражава позитивним реакцијама народних маса и када годинама све владе следе исту политику.

Неутралисање бугарске опасности према Гркој је могуће само одузимањем одређених територија и припајања Источне Ромилије Грчкој. Тако би Грчка добила сигурну границу на Емосу и решила би демографски проблем. Припајање Ромилије би могло заснивати на историјским, геоекономским и политичким разлозима. Ова земља је била независна област Бугарске, становништво није било искључиво бугарско, постојале су бројне грчке заједнице и одржавали су економски живот читаве области. Уједињење Источне Ромилије са Бугарском се догодило путем пуча, након којег је следило генерално искорењавање грчког елемента и промена етнолошког састава области са насељавањем Бугара. И поред ових чињеница јасно је да историјски разлози нису довољни да 
би подржали територијалне претензије, економски фактор је недовољан да неутралише етнолошки састав, а безбедност не оправдава кршење права на самоопредељење. Захтев за Источном Ромилијом не може да се оправда из неколико разлога. Основа стварања држава и територијалних претензија остаје начело самоопредељења. Становништво Источне Ромилије би били против идеје одвајања од Бугарске, а нарочито припајању ове области Грчкој. Такође, није изводљиво насилно удаљавање Бугара из Источне Ромилије. Такав захтев би наишао на негодовање Савезника и Великих сила, и засигурно са Словенима на Балкану и створила би се опасност међународног сукоба на штету безбедности Грчке и мира у региону. То би помогло уједињењу Срба и Бугара, и истовремано би шкодило унутрашњој равнотежи унутар Грчке и одвела би је у једну врсту империјалистичке политике.

Отклањање бугарске опасности ће се постићи сврставањем Бугарске међу поражене у послератном режиму, и предузимањем посебних мера стратешке, политичке и економске природе које би имале за циљ безбедност и опоравак суседних народа од бугарске инвазије. Ревизија грчко - бугарских граница би претстављала озбиљан чинилац за решавање целокупне ситуације.

Ревизија граница је хитна обавеза, колико из разлога опште безбедности, толико и због заштите грчког становништва које се налази у грчкој Македонији и Тракији. Уски појас грчких територија на североистоку земље не може да буде осигуран у циљу безбедности становништва и заштите интегритета Грчке. Гранична линија треба да се премести на праву границу Источне Ромилије, ван македонске територије, као што је било 1912. године уз одређене територијалне измене. Тако би се гранична линија од јужног дела Струмице протезала северно од Петриције и досезала би до Неврокопија, а затим би линија пратила ток реке Арде. Оваквим уређивањем би се удвостручила површина грчких територија у Солунском округу, стратешки би се учврстиле грчке границе и заузели би се области од посебног значаја. 
Ревизија грчко-бугарске линије и удаљавање бугарске мањине из Грчке не решава грчко-бугарски проблем. Решење се налази у посебним мерама разоружавања и контроле са циљем да се уклони свака опасност за балканске народе ${ }^{109}$.

\section{ГРЧКО-ЈУГОСЛОВЕНСКА ГРАНИЦА}

Ратна догађања током Другог светског рата показала су слабости грчко - југословенске границе са гледишта грчке безбедности и интегритета. Немачке војне трупе, пошто су ушле на јужни део српско бугарске границе, без да тако нешто угрожава општу одбрану Југославије, преко Ђевђелије су пресекли Македонију и Тракију и тако поделили Грчку, онеспособљавајућу војна утврђења и отпор на грчко бугарској граници. Преиспитивање грчко - југословенске границе је било неминовно због безбедности Грчке и Балкана, и не може се схватити као претензија према пријатељској и савезничкој Југославији. Намеће се разматрање ове могућности са надом да ће Југославија прихватити један пријатељски разговор на ову тему, или да ће послератно усклађивање Балкана учинити нужни предузимање таквих мера.

У југословенском интересу је да грчка граница буде безбедна, тако да ни један напад с југа у будућности не може да допринесе паду Грчке на штету одбране територијалног интегритета Југославије. Југославија, имајући да заштити врло дугачку границу, није у ситуацији да на југу располаже довољним снагама које би могле да успешно бране јужне границе. Јачање грчко - југословенске границе би спречавало нападе на јужне границе Југославије. Истовремено за Грчку, нова грчко југословенске граница би имала много повољности. На задовољавајући начин би се обезбеђивала Централна Македонија и Солун. Преуређивање граница би створило атмосферу са више поверења између две државе зато што би одстранило србофобију код Грка, а

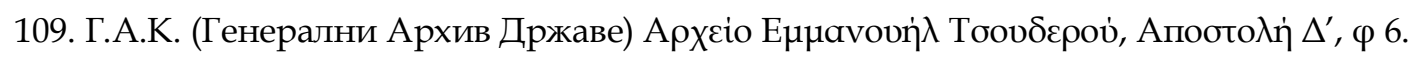


уједно би српске националисте удаљила од илузије о Солуну. Нова граница би обезбедила територијални интегритет Грчке и великим делом би олакшала српску одбрану.

Све горе наведено остварљиво је под претпоставком да ће Југославија имати поново јединствену државу, која ће заједно са Грчком да тежи ка очувању територијалног и мировног режима на Балкану. Другачије би се разматрало питање ако би Јужни Словени одбили да поново изграде јединствену државу. У том случају би дошло до великих промена у ситуацији у региону, и самим тим би се догодиле промене у грчкој политици према Балкану ${ }^{110}$.

\section{ГРЧКО-ТУРСКА ГРАНИЦА}

После малоазијске катастрофе и насилне размене грчког становништва Мале Азије и Источне Тракије, грчко - турски односи су се засновали на новим темељима пријатељства и добросуседства. Заједнички интереси и географски положај обе земље сврставају их у положај савезника. Према томе није могуће испољавање било какве територијалне претензије од стране Грчке према Турској. И поред ове чињенице, требао би да се истражи начин на који ће се регулисати положај Источне Тракије у случају да се постави ово питање на Мировној конференцији. Исход рата ће одредити и нови поредак на Мореузу, као и судбину Источне Тракије. Могуће удаљавање Турске након рата довело би до три могућа решења, а то су: успостављање режима међународне контроле у Тракији, њено уступање Бугарској или њено припајање Грчкој.

Источна Тракија представља природни део Грчке и њено припајање би вратила Грчку у њене природне границе. Историјски Источна Тракија представља област Грчке, пратећи вековима дугу историју хеленизма. Већински део њеног становништва до 1924. године је били су Грци. Источна Тракија заједно са Константинопољом је

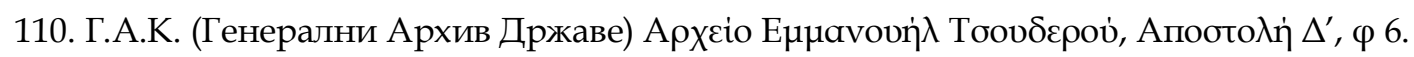


бројала 1.400.000 становника, од којих су 40\% били Турци и 740.000 Грци од којих је већина од њих морала да напусти свој завичај након принудне размене становништва. Припајање Источне Тракије Грчкој би резултирало повратком више од 370.000 избеглица својим домовима, који су били приморани 1924. године да напусте своја родна места. Такође би било могуће премештање дела грчких избеглица из Мале Азије.

Поред историјских, етнолошких и економских чињеница, Грчка заснива своја права на Источну Тракију и у правним документима. Споразумом из Севра, након одлука Врховног Савета Савезника и Америчког Сената, уступљена је Источна Тракија Грчкој, на основу начела самоопредељења народа, и на тај начин признавајући права грчког народа. Након малоазијске катастрофе, споразумом у Лозани је поново предата Источна Тракија Турској, са предусловом обавезног удаљавања грчког становнишва. То доказује да је популација Источне Тракије била грчког ентитета, и самим тим неприхваатљиво је свако решење које је у супротности са правима тамошњег грчког становништва. Решење питања Тракије ће зависити у великој мери од новог режима који ће се одредити за Босфор. Од тог тренутка Грчка неће моћи да захтева ниједну претензију на ову област. Постојање Турске у Тракији се оправдава само под условом да поседује и Босфор. Њено удаљавање са Мореуза ће свакако да отвори питање превласти над Тракијом. Судбину Источне Тракије ће имати и острва Имврос и Тенедос, где живи 15.000 Грка.

Овде се завршавају територијалне претензије Грчке. Неке представљају суштинске захтеве од којих нема одступања, док друге представљају природно заокруживање грчких територија, за које ће се Грчка заузети путем мирољубивих средстава и пријатељских споразума, уколико тако нешто дозволе услови након завршетка рата ${ }^{111}$.

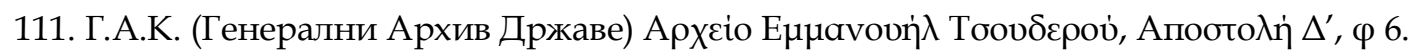




\section{5 ОЧЕКИВАЊА ГРЧКЕ ВЛАДЕ}

Говорили смо о грчким проблемима који захтевају посебну пажњу. Што се тиче проблема о којима ће се разговарати на Конгресу за мир грчке претензије могу да се поделе у три категорије: националне претензије, мере које проистичу из циљева обезбеђивања сигурности и економских потреба. Националне претензије су засноване у Атлантској повељи и немају империјалистички, нити нападачки карактер. Грчка полаже права на Додеканез који већ хиљадама година задржавају своју припадност грчкој нацији, супротно притисцима и нападима Италије против становништва острва. Право на потраживање Грчке за Додеканезом је признато од Сфорца који сад покушава да исправи грешку, али он се у прошлости нимало није трудио да задржи ова острва у Италији ${ }^{112}$.

Такође, Грчка има право да претендује на Северни Епир чији је грчки етнолошки карактер признат у последњем рату. Требало је да останемо при ставу да је део грчког становништва Северног Епира очишћен услед немилосрдне кампање искоренивања који су Италијани започели против становништва користећи као орган албанске власти. Ово, између осталих аргумената, представља још један доказ у прилог теорији за неочување албанске државе. Из истих разлога би било праведно враћање Кипра у оквирима Грчке државе, јер велика већина кипарског становништва је, и увек је била, грчка. Грчки народ је уверен да ће у одговарајућем тренутку велика и савезничка Британија урадити љубазан гест, као што је урадила и у случају Јонских острва.

Што се тиче мера које треба да се предузму за обезбеђење државе, оне морају да буду такве да дају држави географске границе, одбрањиве од било ког напада од стране Бугарске и које у случају напада од велике државе, много снажније, као што се десило у садашњем рату могу да

112. А.Ү.Е. (Архив Министарства спољних послова) Коßв́рvฤоп Каїроv 1943, 24

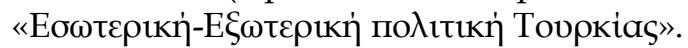


омогуће престанак пробоја непријатеља, док не стигне помоћ савезника Грчке. Таква географска граница би помогла стварању препреке ситуацији у којој би нека велика сила могла да наруши мир на Балкану. У вези са првом констатацијом, потребно је да се северне границе Грчке прошире до Родопа чији врхови морају да припадају Грчкој. Овај захтев Грчке далеко је од тога да буде империјалистички. Једноставно је основни начин обезбеђивања сигурности. Из горњег уређења граница не произилази разврставање бугарског становништва под грчку администрацију. Само Токе (Муслимани), као што су познати становници овог региона, би били у саставу Грчке 113.

У документу Министарства иностраних послова се предлаже да се албанско питање регулише на начин да буде немогуће у будућности да се умеша Италија на Балкану са било којим изговором. Тридесетогодишње искуство показало је да Албанија има недостатак елемената који су неопходни да би задржала независност. Са правом неко може да каже да Албанци имају недостатак етничког осећања. Они су подељени у разне етничке групе, од којих се свака налази потпуно под надлежношћу неког локалног газде. Албанска територија није довољно продуктивна тако да може пружити у будућој албанској држави потребне економске изворе који би дозволили да функционише независно. Ова чињеница, као и малобројна популација Албаније, чине државу која је са једне стране лак плен за било коју силу која покушава да добије политичку хегемонију, а са друге стране разлог за нарушавање мира на Балкану. Два случајна решења која могу да пониште узроке случајне будуће замршености су следећа: формирање двојне државе Албаније и Грчке, или дељење Албаније на северну и јужну, северна би припала Југославији, а јужна Грчкој. У случају да је Грчка више за друго решење, припајањем албанских територија требало би да се у тим областима обезбеди велика локална аутономија. Требало би, такође, да

113. А.Ү.Е. (Архив Министарства спољних послова) Коßе́рvпоп Kaїроv 1943, 24

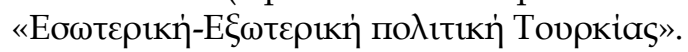


се дају гаранције обезбеђивања нормалног националног развоја Албанаца. Добра страна првог решења је подређеност сличности између Албаније и Грчке која доводи две земље близу и оправдава наду да два народа, живећи мирно под заштитом здравих политичких институција, могу да имају заједнички развој и сличну етничку свест. Основна теза ових надања доказује се у случајевима где већина грчких угледних политичара, као што су адмирал Кудурјотис и генерал Пагалос. Обојица су били председници грчке државе, водећи порекло из породица са простора Албаније, и обојица су познаваоци албанског и грчког језика. Обојици је била израженија грчка етничка свест. Исто се може рећи и о некадашњем потпредседнику Грчке владе, господину Е. Репулију, и о многим другима као што је Колетис, Вулгарис, који су познате политичке личности Грчке. Ако формирање двојне грчко-албанске државе наиђе на отпор, једино преостало решење је припајање северне Албаније Југославији и јужне Грчкој'114.

114. А.Ү.Е. (Архив Министарства спољних послова) Коßв́рvฤоп Каїроv 1943, 24

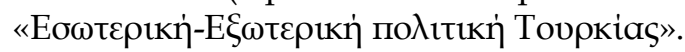




\section{6 СЕВЕРНИ ЕПИР}

Питање Северног Епира је, нажалост још од 1913. године, повезано са проблемом оснивања и очувања независне албанске државе. Грци Северни Епир сматрају делом грчке земље. Историјски, национални и геоекономски разлози намећу уједињење ових области са Грчком, која заједно са преосталим Епиром представља једну целину, која је јединствена вековима. Северни Епир има преко 200.000 становника, од којих већину представљају Грци. Њен етнолошки састав је идентичан, баш као и у остатку Грчке. Њихово становништво не представља ни једну етничку сличност са Илирима, који су се од времена Тукидида и Поливиоса, настанили на територије централне и северне Албаније, прецизније северније од границе Химаре, Клисуре и Преспе.

Северни Епир, као неодвојиви део Епира, у току своје дугачке историје пролази кроз све фазе које пролази и остатак грчке нације. На тај начин Епир прати иста судбина као и остатак Грчке у периоду Византијске Аутократије и Туркократије. За време Устанка 1921. године Епир је, уједињен и неподељен, учествовао у ослободилачким борбама шаљући и своје представнике на четврти национални Сабор у Аргосу 1829. године. Након оснивања грчке државе, упркос чињеници да је цео Епир остао ван граница заједничке државе, наставио је да учествује у сваком националном дешавању. У Северном Епиру је до 1912. године постојало више од 300 грчких школа. Такође, најистакнутије личности друштвеног и духовног живота земље, као и најславнији национални доброчинитељи су били пореклом из овог малог дела грчке земље. Ово историјско јединство целог Епира, Северног и Јужног проистиче из географских и геоекономских чињеница. Оба дела представљају јединствену и хармоничну целину, са центром у Јањини.

Постоје мишљења која негирају грчки карактер Северног Епира јер се у његовом великом делу говори албански језик. То нема неки велики значај за Грчку јер је чињеница да се албански прича и ван Атине 
и на неколико острва у Егејском мору. Мешање становништва за време туркократије и њихов заједнички живот вековима оправдавају овај феномен. Језик, у складу са важећим мишљењем, не представља необорив критеријум националности. Само немачка наука прихвата расу и језик као критеријум нацоналности. Историјски посматрано, род представља основу етничког јединства, али касније то бива замењено заједничким интересима и заједничком традицијом. Постоје многе нације које су се створиле од више раса (Русија). као и многе нације се сажимају у једну расу (жута раса). Допринос језика у националној свести је свакако постојао, али у много мањој мери од расног елемента, и због тога је тај критеријум језика био на неки начин одбачен као одредба за утврђивање националности. Постоје нације које говоре више од једног језика (Белгија, Швајцарска) и насупрот томе, више нација које користе исти језик (англосаксонски). Посебно за Северни Епир, независно од језика, сва национална, духовна и економска изражавања његових грађана вековима доказују управо њихову грчку свест и јаку жељу да се уједине у заједничкој отаџбини.

Национална структура становништва Северног Епира се сасвим променила од 1913. године после организованог истребљења или измештања грчког становништва од стране албанске, а касније и италијанске владе. Ово објашњава мноштво Северноепираца који су се разишли на пет континената и који никада не заборављају да нагласе своје грчко порекло. Дело Албанаца и Италијана настављају Немци који пустоше грчка села Северног Епира у одмазди према грчким побуњеничким покретима који делују у овој области. Најчудније је то што албанска пропагада покушава да искористи за себе овај грчки герилски покрет у Северном Епиру у тренутку када су ти покрети састављени од северноепирских Грка који се боре истовремено и за слободу Грчке ${ }^{115}$.

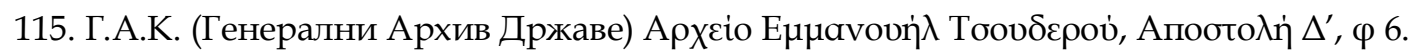


Осим неопозивих права Грчке над Северним Епиром, постоје међународни споразуми који признају припадност Северног Епира Грчкој. За време Балканских ратова од 1912 - 1913. године грчка војска је ослободила Северни Епир од Турака и преузела га је према споразуму потписаног између Грчке и Србије (Венизелос - Пашић 1913. године).

Када је почела евакуација грчких трупа у складу са наредбама из протокола из Фиренце (17. децембра 1913. године) локална влада под вођством Зографоса је преузела власт и одбила је да преда Северни Епир албанској управи. После дугих преговора потписан је протокол на Крфу (17. марта 1914. године) који гарантује широку локалну аутономију и значајне привилегије за грчко становништво. Овај акт представља међународно признање етнолошког састава Северног Епира који је, из чисто политичких разлога и у супротности са вољом становника, припојен албанској држави.

У периоду Првог светског рата грчка војска је, након наређења савезника, по други пут освојила Северни Епир. Неколико међународних уговора и пракси су признавали грчки карактер ове области и подржавали су уједињење са Грчком: споразум Савезника и Италије (13. април 1915. године), споразум Венизелос - Титони (29. јул 1919. године), одлука Врховног одбора Савезника (13. јануар 1920. године) и једногласна одлука Сената Сједињених Америчких Држава (17. мај 1920. године). Током Другог светског рата грчки народ је по трећи пут, у периоду од тридесет година, пролио крв за Северни Епир. Тамо се одиграла велика битка против фашизма и забележена је прва победа демократских снага. Све горе наведене одлуке и споразуми стварају чврсте темеље за права грчког живља у Северном Епиру.

За утврђивање грчко - албанских граница нужно је прво решавање питања безбедности Грчке. Постоје три граничне линије које могу да се испитају:

- Гранична линија Скубин - Елбасан - Северни део Охрида. Ова граница се нуди као једина погодна у случају дељења Албаније, 
штавише сасвим се прихвата за потребе грчке безбедности, иако изузев Северног Епира садржи и територије настањене Албанцима.

- Граница Аотос - Томарица - Јужни део Охрида заједно са луком Авлонас.

- Иста граница до Акрокеравнија без Авлоне. Ова лука је неопходна за економски развој унутрашњости земље, и може да буде под посебним режимом служећи целом Балкану.

Последњи проблем који је преостајао да се реши је било одређивање судбине албанске мањине на територијама која припадају или ће припадати Грчкој. У случају да Албанија постане независна држава, замена или имиграција албанске мањине Епира се намеће из разлога добросуседских односа и очувања мира на Балкану. Тако би нестао последњи траг раздора између два народа.

Решење Северноепирског проблема се не везује са обновом албанске државе. Решавање овог проблема ће утицати на режим и судбину мањина, као и на разграничавање између две државе ${ }^{116}$. Албански проблем, који се није доводио у везу са Северним Епиром, посебно занима Грчку са гледишта безбедности њеног интегритета и очувања мира на Балкану. О поновном оснивању независне албанске државе било је речи још од давнина. Многи су веровали да није могуће постојање албанске државе, из разлога што не поседује потребне особине за очувања свог интегритета и независности. Самим тим њене слабости представљају озбиљну опасност за безбедност њених суседа и мира на Балкану. Историја доказује тачност оваквог расуђивања. Албанија није успела никада да стварно буде слободна земља, нити да очува своју независност. За време Балканских ратова албански народ није помишљао, нити је био у положају, да затражи своју независност. Заостао, подељен у међусобној борби племена, са неодређеном националном свешћу, борио се са јединим циљем да му се признају

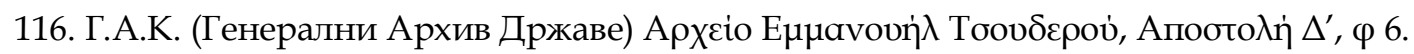


посебне повластице и локална самоуправа унутар Отоманске Аутократије. Пад Царства и његово удаљавање са Западног Балкана поставило је албанско питање актуелним.

Решење које је преовлађивало у јавном мишљењу је било дељење Албаније између Грчке и Србије на граничној линији Скуби (Споразум Венизелос - Пашић из 1. јануара 1913. године) пошто ће се сложити да су састав, ниво становништва, недостатак зрелости и економски услови незадовољавајући за оснивање албанске државе, чак и под руководством султана. Овом мишљењу се успротивила Аустроугарска влада подржана од стране Италије. Настањивање Срба на Јадранском приобаљу је наилазило на потпуно одбијање као супротност интереса две државе, док би постојање албанске државе олакшавало проширење њиховог утицаја на цео Балкан. Потпуна несагласност Аустрије и њен претећи став је наметнуо на скупу амбасадора, у Лондону 1912. године, оснивање албанске државе, њену потпуну независност и припајање страних територија истој, међу којима је и цео Северни Епир. Док се није учврстила ова вештачка творевина потпуна анархија је владала у целој Албанији због немоћности наметања централне власти. Недуго затим избио је и Први светски рат, који је изнео на површину питање албанске независности.

Догађаји који су уследили доказали су неуспели покушај овог експеримента, и заједно са нестајањем Аустроугарског Царства имали за последицу напуштање идеје о независности албанске државе. Тако су многи међународни споразуми осудили њено постојање. Споразум Италије и Савезника (13. април 1915. године) доводи до распарчавања Албаније, где је Северни Епир препуштен Грчкој, а Северна Албанија Србији, а око Драча је призната једна мала муслиманска држава под италијанским утицајем. Споразум Титони - Венизелос (29. јул 1919. године) је Грчкој уступао Северни Епир у замену за признавању италијанског утицаја над остатком албанске државе. Велике савезничке снаге су децембра 1919. године дале право Италији да преузме луку 
Авлона заједно са њеним континенталном делом. Ови споразуми су потврдили слабост постојања независне албанске државе, и циљали су на њену поделу или успостављање италијанског протектората. На лето 1920. године запажена је ризична промена у италијанској политици која се приписује унутрашњим разлозима и новом дипломатском усмерењу њене политике. Италија је одустала од права на Авлону и постала је велики заговорник независности Албаније са истим границама из 1913. године, истовремено оспоравајући споразум Венизелос - Титони. Италија наставља политику Аустрије, имајући велике амбиције да преузме њен утицај на Балкану и на Јадрану.

Очување албанске независности је била немогућа без помоћи страних снага. Италија је, у име Великих Сила, добила (новембра 1921. године) посебно право утицаја и привилегије над Албанијом. Пошто је покушала да затражи помоћ од Југославије, Албанија се окренула Италији, која ју је подредила економски сталним покривањем годишњег недостатка њеног буџета са 3 милиона златних франака, натерала је да потпише споразум у Тирани (1926. године) којим је одредила за италијански протекторат и довела до војног освајања Албаније, што представља наговештај италијанске инвазије на Грчку. Историја албанске државе у периоду 1913-1939 доказује да је албански народ још увек био неспреман да сам управља државом, да опстане сасвим независтан и да албанска држава не може да створи погодне услове за нормалан економски живот без стране интервенције. Постојање независне државе, само од себе није довољно да се обезбеди слобода албанског народа и представља опасност за независност суседних народа и очување мира на Балкану.

За решавање албанског проблема могућа су три решења: подела Албаније између Грчке и Југославије, припајање Албаније Југославији или Грчкој, или стварање албанске државе без страних елемената под одређеним условима. Подела Албаније није могућа, не само зато што је била у супротности са начелом самоопредељења, него је и у супротности 
са одредбама Атлантске повеље и изјавама Хола, Идена и Молотофа у којима се албанском народу признаје право на слободу опредељења и избор сопствене владе. Албански народ је нација чија права су неоспорна, и као таква има право на слободу и независност. Ово је невезано од слабости коју је показала у очувању своје независности и у орагнизацији слободне власти, за које треба да се предузму одређене мepe $^{117}$.

Даље се тврди да подела Албаније не иде у прилог ни грчким интересима. По граничној линији Скуби, већи део Албаније би припао Југославији. Тако постоји опасност од уједињења Албанаца из Албаније и Југославије под заједничком управом и да се створи компактна народна маса која би могла, под владом вођеном империјалистичком политиком, да се окрене против Грчке и под маском ослобођења „поробљене браће“ да постави претензије све до области Амвракикоса у Грчкој. Ову политику је следила Италија како би створила свој протекторат у Албанији и тиме олакшала напад на Грчку. Оваква врста опасности не постоји од стране Југославије, са којом се Грчка повезује пријатељством и заједничком борбом. Титове изјаве за оснивање велике федеративне јужнословенске државе и његов позив Албанцима представљају догађаје које треба озбиљно истражити и можда преиспитати преусмеравање грчке политике према албанском проблему. Албанска опасност би била још више уочљива у случају где би Албанци били обухваћени у један јак државни организам

Са граничном линијом Скуби, унутар Грчке би се нашло албанско становништво. Тиме би било немогуће измештање из Епира постојећег албанског живља и са увећаним бројем становника албанске мањине, пре или касније би се створио ослободилачки покрет. Штавише, Епир би тако изгубио своју једнородност и појавила би се опасност унутрашњих немира и вероватно спољњих сукоба. Подела Албаније би поново довела у везу питање Северног Епира са свеукупним албанским питањем, које 
ће пре или касније опет постати актуелно, као задовољење природног права једног народа на слободу и уједињење. Политика Грчке настоји да коначно раздвоји будућност Северног Епира од судбине албанског народа и да тако прекине вештачку везу коју је аустријска политика произвела између ова два питања. Поделом Албаније Југославија би имала већу добит од Грчке, и њени интереси би се још више ширили према југу. Грчка сматра најисправнију политику да се колико год је могуће спречи стремљење Срба према југу, и самим тим да се појачају њихови апетити ка северу. Нестајање албанске државе ће из политичког живота Балкана удаљити једну не-словенску земљу, која би у будућности могла да учествује у организацији Балканског Полуострва и заједно са Грчком би могла да резултира суштинским уравнотежењем политике две словенске земље. Улога албанске државе има још већи значај ако се узме у обзир да је Турска из географских разлога имала ограничена права на Балкану, а да Руминија због посебног послератног положаја не би могла да има значајнији утицај.

Решење припајања Албаније Југославији не може бити подржано са грчке тачке гледишта, јер горе наведене опасности њене поделе у овом случају директно угрожавају грчке интересе. Тиме бива веома проблематично коначно решење албанског проблема у складу са грчким националним претензијама. Припајање целе Албаније би представљало прекршај начела националности и имало би за последицу стварање велике јужнословенске државе којој би приступила и Бугарска. Ова коалиција би Грчку ставила у други план и значајно би смањила њену улогу на Балкану.

Решење припајања Албаније Грчкој није у складу са тадашњим међународним принципима. Припајање Албаније под било каквим законским окриљем, било то обично припајање, или протекторат, или као уједињење имало би неколико последица. Ова догађај би у очима међународне јавности био протумачен као освајачки чин. Такође, ово решење не би било прихваћено од стране Југославије, осим у случају да 
им се уступе северне територије Албаније. Границе Грчке би се помериле доста према северу и високо према Јадранском мору, и тако би се додао нови чинилац у грчкој спољној политици. На тај начин би се створила могућност појаве будућих несугласица са њеним северним сусједима. Судбина Северног Епира би се решавала заједно са албанским питањем, и као таква би била на штету грчких националног интереса. Грчка би била у опасности да изгуби равнотежу, јединство и свој мир. Била би обавезна да пази на своју унутрашњу безбедност располагајући са способном војском за гушење сваког покрета и одржања реда. Изгубила би велику привилегију националног јединства својих становника. Уједињење Албаније и Грчке би проузроковало проблеме, унутар и ван граница земље, без икакве стварне користи, јер је у питању једна сиромашна земља, без значајних природних ресурса.

Очување самосталне албанске државе остаје као највероватније решење, које је у складу са савременим међународим духом, са принципима Уједињених Нација и са грчким интересима. Међутим, ова слобода не може да буде потпуна, нити да се проширује на сва права једне самосталне државе без ограничења и изузетака, јер потпуна независност Албаније представља опасност за слободу албанског народа, интегритет суседа и стабилност мира на Балкану118.

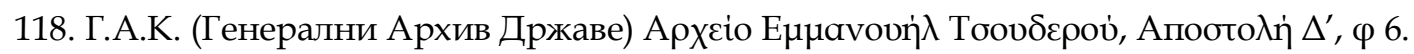




\section{7 ДОДЕКАНЕЗ}

Додеканез представља скуп 14 великих острва: Патмоса, Лероса, Калимноса, Коса, Астипалеа, Нисироса, Тилоса, Халкија, Симија, Родоса, Карпатоса, Касоса, Кастелориза, Липсија и многобројних, ретко насељених или ненасељених, мањих осртва. Италијанско присуство на Додеканезу датира још од 1912. године. Тада су Италијани изјавили да ова окупација има привремени карактер, и да ће бити окончана након италијанско-турског рата. Такође су остављали отовреним питање аутономије ових острва ${ }^{119}$, чињеница која је потпуно задовољавала Грчку. Међутим ствари су се одвијале другим током. На почетку Балканских ратова Италија је потписала мир са Турском, обавезујићи се да неће напустити Додеканез пре него што буду прекинути сви упутрашњи отпори у Либији ${ }^{120}$.

На Конференцији о миру у Паризу, у документу грчког премијера међу грчким захтевима није постојао Додеканез, и поред тога што је учесницима конгреса наглашен њихов грчки карактер. Препрека је била, као и у случају Кипра, то што је припадао савезничкој држави. Повољна прилика за тако нешто је дошла касније, мало пре грчког искрцавања у Смирни. Тада је Венизелос покренуо иницијативу за проналажење решења са Италијанском владом. То је резултирало чувеним споразумом Венизелос - Титони, 29. јула 1919. Године, који је окарактерисан као Венизелосов дипломатски успех. На основу овог споразума Грчка ће одустати од области Мендесе и Аидинију у корист Италије и признаће стварање италијанског протектората у Албанији. За

119. Када су се 22. маја искрцали на Додеканез главешине италијанских снага генерал Амелиос и адмирал Презвитерос изјавили су да ће за време закључивања мира италијаско-турског рата острва да добију режим аутономије (Детаље за италијански

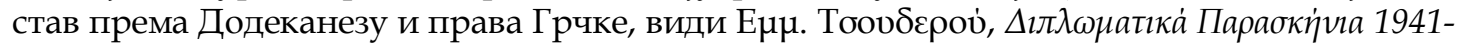
1944, AӨn்val, 1950, oo. 239-243).

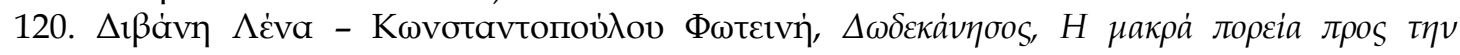

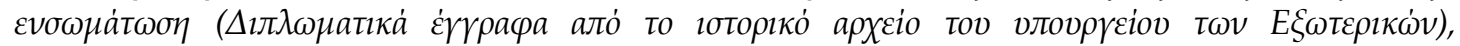

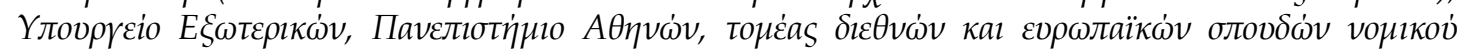

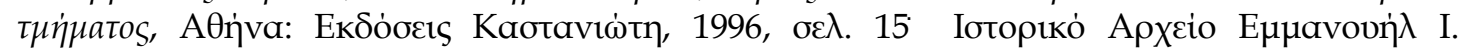

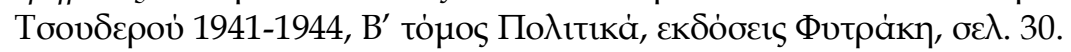


узврат, Италија ће признати проширивање грчког појаса окупације у унутрашњости Смирнија, подржаће грчке претензије у Источној и Западној Тракији и у Северном Епиру и одрећи ће се права која је добила Мировним споразумом над Додеканезом у корист Грчке, изузев Родоса. Овај споразум је поништила нова влада Ђиолитија у јулу 1920. године. Након Венизелосовог протеста потписан је нови споразум 10. октобра 1920. године са истим садржајем, али са условом да ће важити само након ратификације споразума из Севра од стране Турске, до чега никада није дошло ${ }^{121}$. Амерички Сенат, 17. маја 1920. године, доноси одлуку да Северни Епир (обухватајући и Корицу), Додеканез у Егејском мору и западна обала Мале Азије, где преовлађује грчки живаљ, треба да на Конференцији о миру припадну Грчкој и да буду припојене Краљевини Грчкој122. После малоазијске катастрофе, споразумом из Лозане (члан 5), Турска је и званично одустала од својих претензија над Додеканезом и одлучено је (члан 16) да се питање регулише између Италије и заинтересованих страна. Резумирајући видимо да Грчка у овом периоду, из разних разлога и околности, није повратила власт над острвима, али је створила добре предуслове на међународној сцени за будуће акције које ће предузети у том правцу.

Послератно политичко-економско стање и међународни положај Грчке није дозвољавао експанзивне амбиције. Грчка је, у покушају да се споразуме са Италијом, оставила по страни Додеканез. Уочи потписивања споразума грчко-италијанског пријатељства 23. септембра 1928. године, Венизелос је изјавио: „Није могуће, и не треба да Додеканез

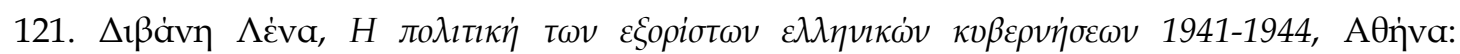

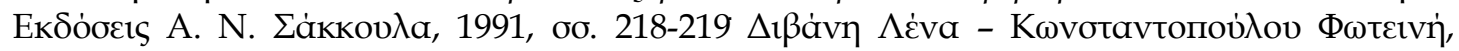

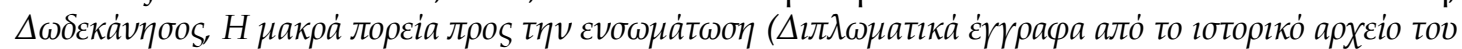

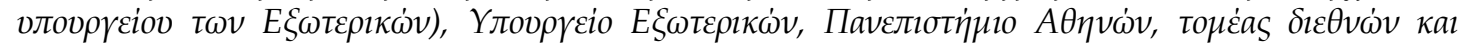

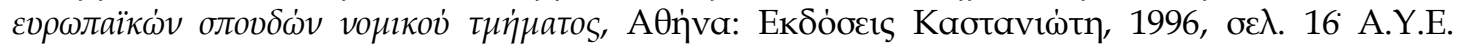

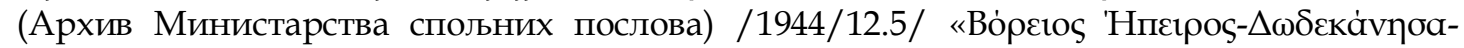
ЕӨvıка́ Өغ́цата» А.Ү.Е. (Архив Министарства спољних послова) /194/14.3/

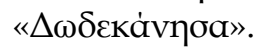

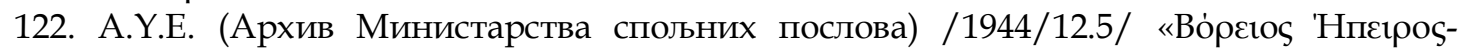

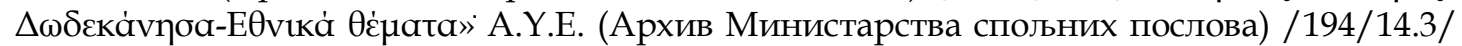

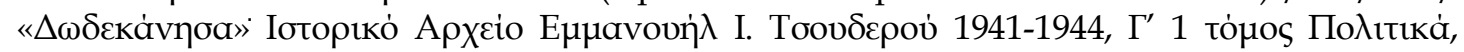

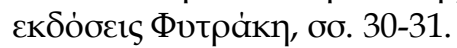


спречава развој и стабилизацију пријатељских веза и јачање поверења између Грчке и Италије “123, али истовремено се побринуо да буде међународно признат грчки карактер острва, обезбеђујући на тај начин националне и образовне слободе грчког становништва, у мери колико је то било могуће 124.

Међутим, Турска и поред њеног одустајања од Додеканеза према споразуму у Лозани, није остала по страни. Повод за њено друго уплитање је био Други светски рат, у којем су Велика Британија и Француска затражиле њену помоћ. Преговори су довели до потписивања споразума узајамног помагања Француске-Енглеске-Турске 19. октобра 1939. године, који је предвидео да ће Турска пружити сву могућу помоћ својим савезницима у случају офанзивних активности неке европске силе која би водила ка рату у Средоземљу. Такође би помогла својим савезницима ако би се уплели у рат због гаранција које су потписали Грчкој и Румунији, у априлу 1939. године. Енглези и Французи ће, према споразуму, помоћи Турској ако би постала жртва нападачког акта неке европске државе или ако би ушла у рат због њених обавеза које су произилазиле из Балканског Споразума ${ }^{125}$. У овом споразуму постојао је и војни уговор, према чијем члану 3 је предвиђено да ће за могући подухват окупације Додеканеза бити употребљене турске снаге у сарадњи са расположивим британским у том тренутку126. Ово је био савезнички покушај да добију подршку Турске у рату. Међутим, Турци нису хтели да изађу из режима неутралности. Након

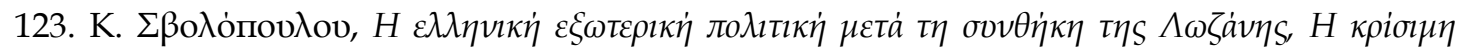

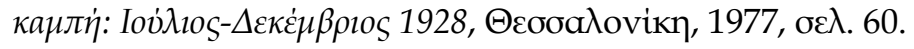

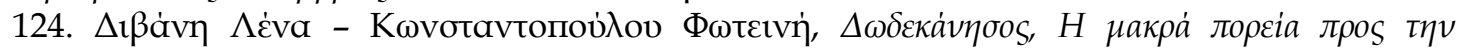

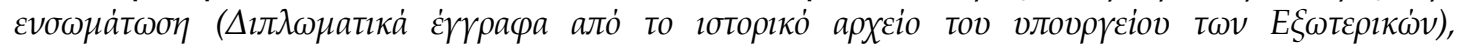

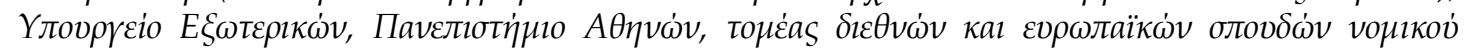

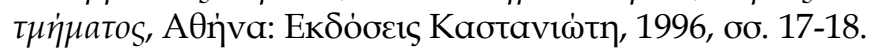

125. За прилог овог споразума као и за друге везе Турске са савезницима и Грчком у Другом Светском Рату види чланак A. Alexandris, «Turkish policy towards Greece during the second world war and its impact on Greek-turkish detente», Balkan studies, vol. 23, No 1, Thessaloniki, 1982, pp. 157-197 $\Delta$ ı

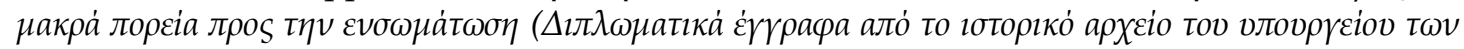

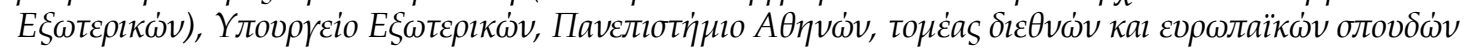

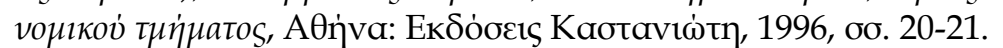

126. F.O. 371/37224, R 2097. 
потписивања овог споразума су се побринули да обавесте Немце да одлука није била једногласна и да није обавезујућа, како би умириле и другу страну. У овом случају, у оквиру њихових сталних преговора са савезницима искористили су прилику да истакну свој интерес за Додеканез. Није занемарљива чињеница да, чим је избио грчкоиталијански рат, турски министар Спољних послова Русди-Арас изјавио је да сматра да су Додеканез, Бугарска, Тракија и Албанија у сфери утицаја Турске ${ }^{127}$.

Ово питање је тада остало неразрешено, јер Турска није помогла Грчкој у рату. Покренуто је међутим нешто касније, у децембру 1941. године. У том периоду Иден је тајно отишао у Москву како би разговарао са Стаљином. Тема њиховог разговора било је, између осталог, и придобијање Турске на страни савезника. Стаљин је предлагао Идену да привуку Турке тако што ће им понудити Додеканез и део јужне Бугарске. СССР се свакако побринуо да ове понуде дођу до ушију званичника Турске ${ }^{128}$. Ове информације су стигле и до знања избегличке владе изазивајући велики немир и реакцију амбасаде у Лондону упућеној Форин Офису. Тако је Пипинелис у телеграму од 30. јануара 1942. године изјавио следеће: „Из два добро обавештена извора истовремено сазнајем да је Русија својим ставом признала турске претензије над Додеканезом, ако не и за још нека острва у Егејском мору. Изнео сам у свом телеграму који су били моји извори и самим тим је могуће да из тих извора тачно утврдимо шта се догодило. Био бих вам захвалан да ме обавештавате о даљим догађајима у овом случају, јер ако нису у питању мала приобалска острва јасно је да је величина проблема огрмона за даљи развој догађаја око Додеканеза. На овај начин губимо шансу да изложимо совјетској влади наше захтеве и да на тај начин

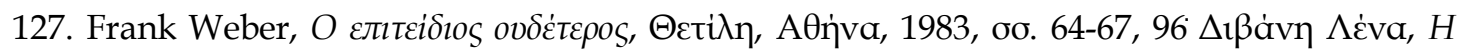

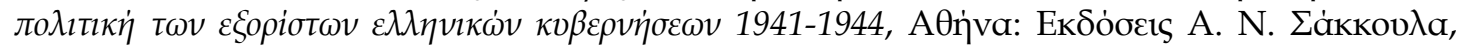

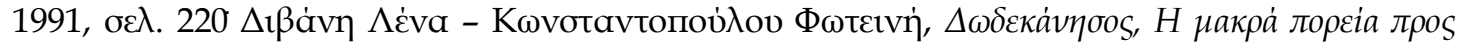

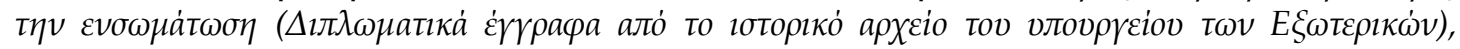

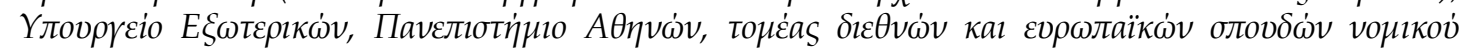

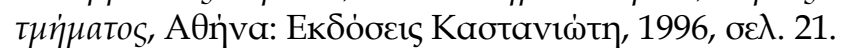

128. F.O. $371 / 33183$, R 458. 
избегнемо обезбеђивање турских претензија у руској политици. Могућност да је Русија тако поступила после турске молбе, мислим да ван сваког разговора“129.

Цудерос је 2. фебруара 1942. године одговорио следеће: „Информације долазе од самог Идена који је разговарао са Краљем. Сматрам да о проблему не треба да разговарамо са Турцима, иако смо информисали овдашњег турског амбасадора да што се тиче Додеканеза са наше стране не долазе у обзир било каква одступања. Слажем се са вашим мишљењем да обавестимо Русе о нашим претензијама“130. Стални заменик министра Иностраних Послова Велике Британије А. Кадоган умирио је грчког амбасадора, након што му је поновио још једанпут став да када је у питању Додеканез, ни једна одлука неће бити донета без претходног договора са Грчком владом, додајући да разуме да је ово питање од виталног значаја за Грчку“131. Заиста, према британском архиву, Иден је подсетио Стаљина на стање ствари у вези Додеканеза, као и на проблеме које би могла да изазове у савезничком табору један такав договор с Турцима. Грчка влада је била много агресивнија у претензијама на Додеканез у односу на случај Кипра, из простог разлога што су њени противници били из супротног табора или су били неутрални. Ова чињеница, као и неоспорно грчко порекло становништва на острвима, давало јој је и правну основу да отворено претендује на припајање егејских острва грчкој држави.

Додеканез је одувек заузимао прво место у свим документима о националним претензијама које је, с времена на време, подносила

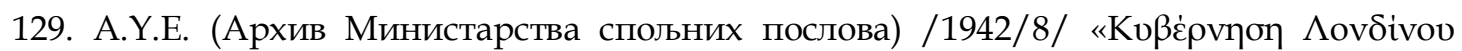

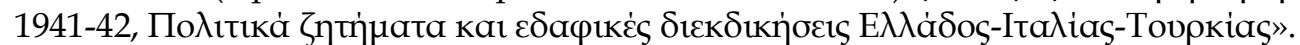

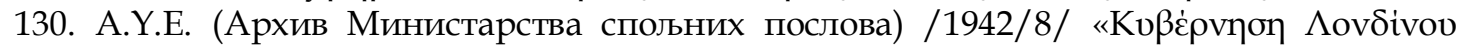

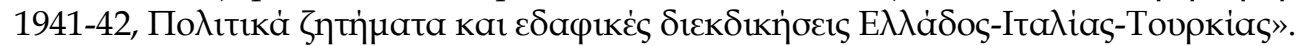

131. Текст извештаја грчког амбасадора с датумом 7. март 1942. године постоји у књизи

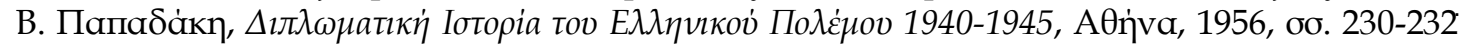

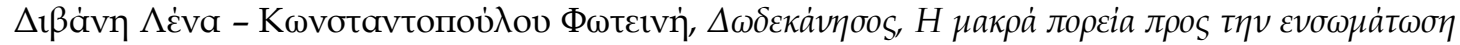

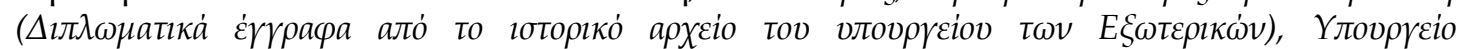

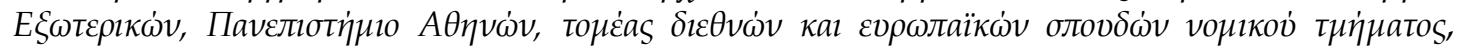

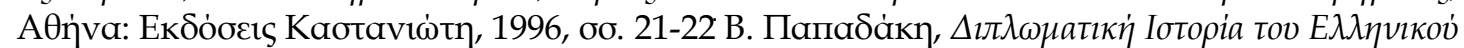

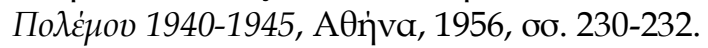


емиграциона влада савезничким органима власти ${ }^{132}$. Тако је од самог почетка, већ у периоду последњих месеци 1942. године, чим се појавила могућност војних операција на Додеканезу, Панајотис Канелопулос затражио од савезничког министра Средњег Истока да се употреби грчка војска у тим операцијама. Истовремено је прецизирао да не побуђује ниједну од територијалних претензија, већ ће о њима бити речи после рата. Једноставно је то сматрао питањем морала и части да и грчка војска учествује у сваком подухвату који има за циљ ослобађање грчког становништва ${ }^{133}$. Став Форин Офиса био је да немају ништа ништа против коришћења грчке војске, али да су то питања стратешког карактера и да задњу реч имају надлежни савезнички органи ${ }^{134}$.

Догађај који је заиста узнемирио Цудеросову владу је био састанак Черчила са Турцима у Адани, који је имао за циљ да притисне Турску да још једанпут помогне Черчилу да оствари свој план на Балканском фронту. Грчка страна је имала итекако разлога за забринутост, јер је од почетка Додеканез представљао јаку преговарчку карту за улазак Турске у рат. Разлог више за грчку забринутост је био и тај што је, непосредно пре преговора у Адани, турски амбасадор у Лондону незванично рекао Цудеросу да његова земља испитује могућност да поново преузме нека средоземна острва135. Чињеница је да је неколико месеци пер тога исти тај амбасадор изјавио да Турска нема ништа против да Додеканез пређе у руке једне пријатељске Грчке, тако да се грчка избегличка влада с

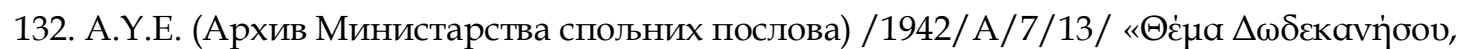

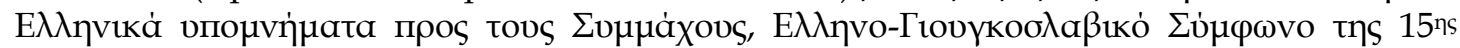
Iavouapiou 1942»

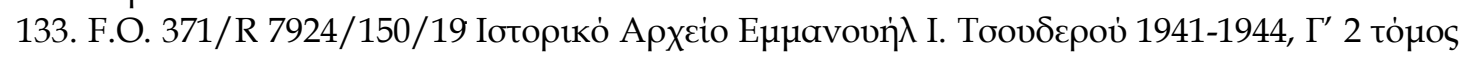

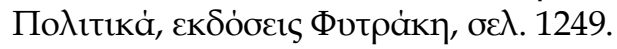

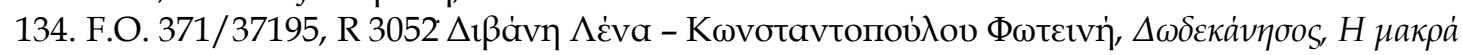

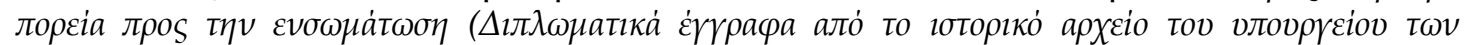

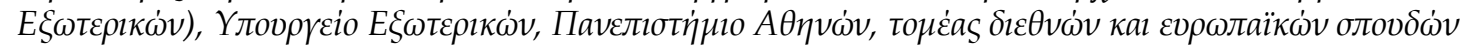

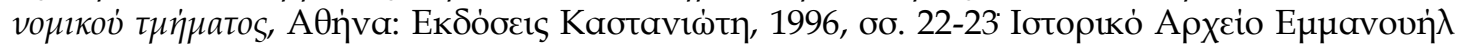

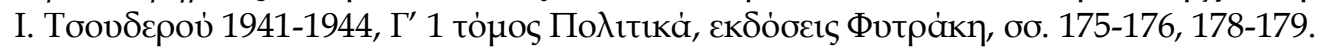

135. A. Alexandris, «Turkish policy towards Greece during the second world war and its impact on Greek-turkish detente», Balkan studies, vol. 23, No 1, Thessaloniki, $1982 \Delta$ ıß̊́v $\eta$

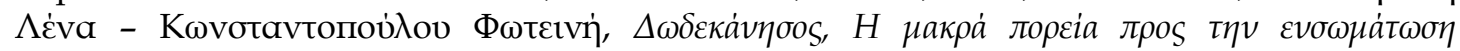

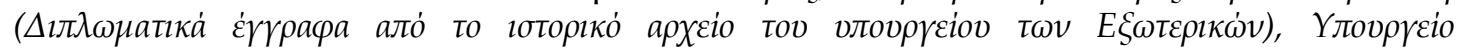

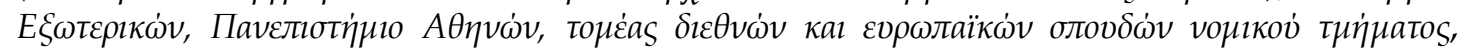

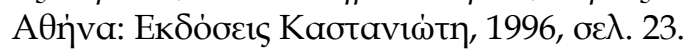


разлогом забринула да у датом тренутку Турска, подстакнута и падом Италије, не покуша да промени свој дотадашњи став по питању егејских острва ${ }^{136}$.

Амбасадор А. Агнидис је 1. фебруара 1943. године разговарао са О. Саргентом из F.O-а о страховањима Грчке владе. Нагласио је да је могуће да Турци покушају да учествују у ратним операцијама на Додеканезу, као и у операцијама ослобађања острва у Егејском мору која већ припадају Грчкој, као што су Хиос и Митилини. Британаски изасланик се побринуо да умири Агнидиса рекавши да Британска влада не занемарује интерес Грчке у области Егеја, али једино јасно обећање које је дао било је да не постоји опасност да изгубе острва која већ припадају Грчкој, на чему се обавезала Британија у војном споразуму са Грчком из 9. марта 1942. године ${ }^{137}$. У Саргентовом службеном допису наглашава се да ће званични извештај турске и британске владе у вези са преговорима у Адани бити дат у јавност 2. фебруара 1943. године, дан након његовом разговора са Агнидисом. Прибојавао се да ће Грчка влада подићи тон на следеће изјаве: „Турско и британско вођство заједно су преиспитали тренутну ситуацију у Европи, а посебно ситуацију у областима за које се Турска непосредно интересује. Постоји усаглашени ставови око свих основних питања“. Још једна, потенцијално опасна, изјава је гласила: „Такође се разговарало о проблемима за које је могуће да искрсну после рата и дошло се до договора и по тим питањима“. Како би предухитрили бурну реакцију од стране Грчке, Саргент и Иден су се усагласили да предложе Черчилу да исти умири Цудероса враћајући се из Адане ${ }^{138}$. Неколико недеља пре овога дошло је до велике узрујаностх у

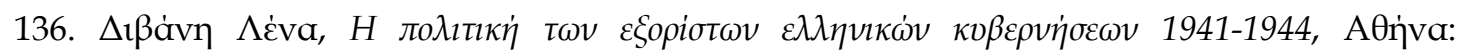

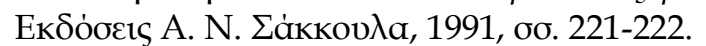

137. F.O. 371/37224, R $942 \Delta$ ı

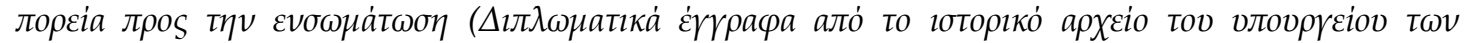

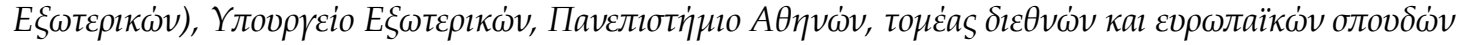

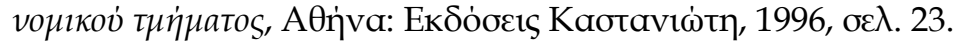

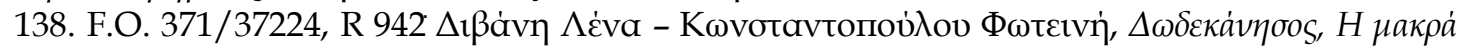

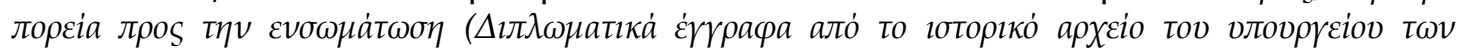

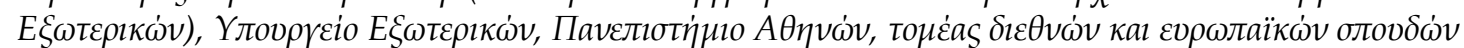

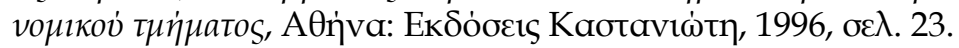


грчкој влади због албанског питања. Било је јасно да грчко-британско пријатељство није могло да поднесе још један ударац у тако кратком временском року.

Узнемиреност избегличке грчке владе је достигла свој врхунац првих дана фебруара, као што је предвидео Саргент. П. Канелопулос је 2. фебруара 1943. године био у Лондону на разговоре. О томе је забележио у свој дневник: „ Данас пишу да се разговарало у Адани о питањима која се односе на Грчку, а посебно на грчка острва. Непојмљиво је да се разговара о таквим питањима, а да нас не обавесте о томе“139. Черчилов долазак на Кипар је смирио страсти, изјављујући да „ће Грчка заузети почасно место међу победницима које ће бити вредно њених жртава“. Ово је од стране грчког Министарског савета било сматрано као окрет у корист Грчке и томе је придат велики публицитет у дневној штампи. На овај начин је даље незадовољство грчке прекинуто, јер је убрзо постало јасно да преговори у Адани нису имали велики значај ${ }^{140}$.

Проблем је и даље постојао, и што се приближавала могућност војних операција на Додеканезу све су учесталија била саветовања у јужном региону Ф.О. Званичан допис од 7. априла 1943. године појаснио је ставове британског Министарства Спољних послова. У њему се каже да ће о захтеву Грка за уједињењем Додеканеза са Грчком одговорити да не желе да се обавезују за ништа у датом тренутку, али да су крајње позивитни према њему. О грчком захтеву за учешће грчке војске у будућим операцијама на Додеканезу одговориће да је то војна ствар, али да ће и према томе имати позитиван став. Око учешћа Грка у будућој владавини над Додеканезом, ствари су биле много компликованије. Британска влада је 1940. године обећала Турској влади, уз знање Метаксаса, да неће дозволити грчку управу над острвима у случају

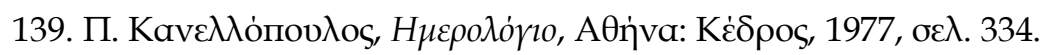

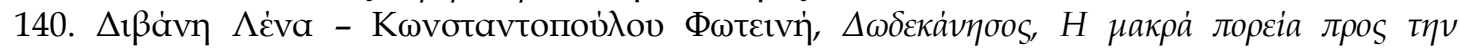

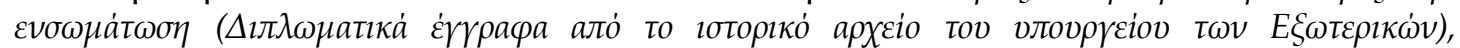

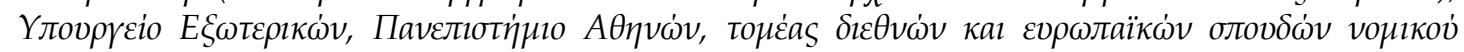

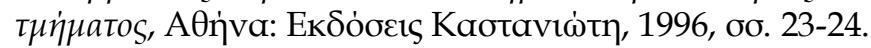


њиховог освајања. Ово обећање се законски ослањало на члан 3 војног уговора из 1939. године, који је одређивао да ће се у операцији освајања Додеканеза употребити углавном турске снаге. Међутим, предуслов за примену члана 3 је био да Турска буде савезничка држава која, као што је познато, то никада није постала. Према томе, наглашено је да је Велика Британија слободна да се не придржава овог споразума, имајући у виду да би ово донело велике немире у британским односима са Грчком и Турском. Допис се завршава жељом да не затреба учешће Турске војске у будућој операцији на Додеканезу, јер би у том случају Турска сигурно тражила нешто у замену за то и ствари би постале много компликованије $\mathrm{e}^{141}$.

На основу ових ставова, Иден је одговорио на Черчилов телеграм од 4. априла 1943. године, где предлаже да затраже помоћ од Турака, коришћење ваздушног простора и база или потпуну војну сарадњу, у замену за Родос. Иденов одговор је био негативан, с мишљењем да Турци поново неће испоштовати обавезе једног таквог договора и једини резултат би био кршење доктрине „разговори о територијалним питањима после рата“ и огорчење савезничке Грчке ${ }^{142}$. Било је изузетно тешко за Британце да усмено објасне Турској да се члан 3 Војног уговора није сматрао важећим, јер је он био једина обавеза између две земље. Једина сигурна ствар коју су могли да ураде тада, крајем априла 1943. године, је била да избегабају разговоре са турским властима који су се тицали Додеканеза, да их не охрабрују и да не обавезују Британску владу у одмосу на члан 3. Поред тога, могли су само да се надају да им неће затребати турска помоћ, иако је војна команда Средњег Истока већ

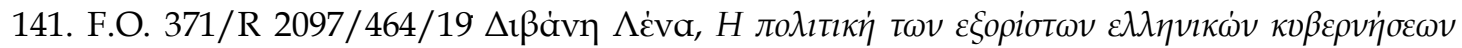

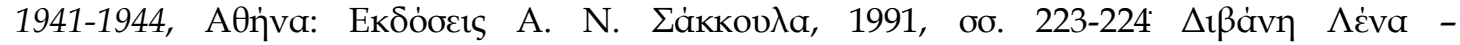

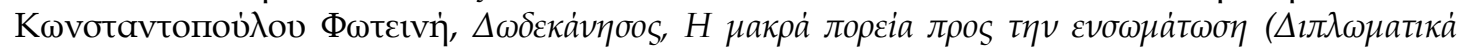

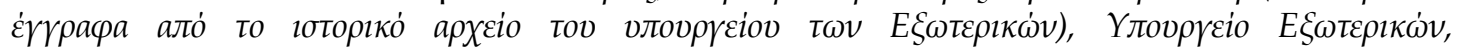

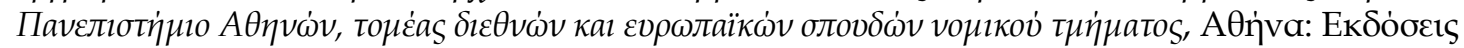

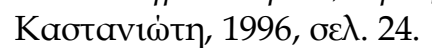

142. F.O. 371/R 3136/464/19. 
припремала два плана операције за Додеканез, од којих се један односио на чисто британску операцију, док је други предвићао и турску помоћ143.

Истовремено са питањем војних операција за ослобођење Додеканеза, Форин Офис је припремао уводно излагање у вези са темом привременог управљања ослобођених територија. Форин Офис је, 2. јула 1943. године, обавестио врховног команданта Средњег Истока и Липера о одлукама које су одобрене и од стране Ратног Савета. Према њима Додеканез је сматран пријатељском територијом. Италијански закони би се очували као привремено важећи, модификовани у деловима који се односе на дискриминацију грчког или турског становништва. Команда би била формално и суштински под британском надлежношћу. Високопостављени Италијани не би били ангажовани. Такође не треба да се ангажују ни Грчки ни Турски држављани у управи над острвима. Наравно да би могли да се ангажују становници острва или избеглице са Додеканеза који су се у то доба обучавали на Средњем Истоку 144. Запажамо да је Британска влада прижељкивала учешће грчке војске у војним операцијама на Додеканезу и да није желела мешање Турске у њима. Истовремено није желела да да повод ни Грцима ни Турцима за сумње да Британија подржава једну или другу страну. Држећи привремено управу у својим рукама, држала је на истом одстојању обе претендујуће суседне земље.

Овај случај није уопште задовољио избегличку грчку владу, која је већ од септембра 1943. године била тражила, осим војног учешћа у ослободилачким операцијама острва, да учествује и у њиховој привременој управи ${ }^{145}$. Иако је Липер одговорио да је предвиђено да

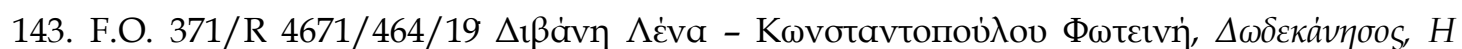

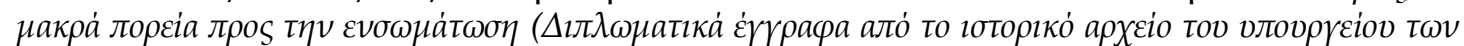

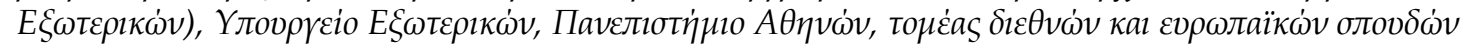

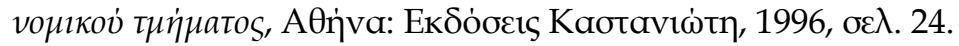

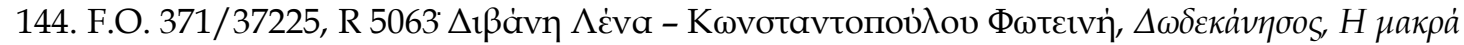

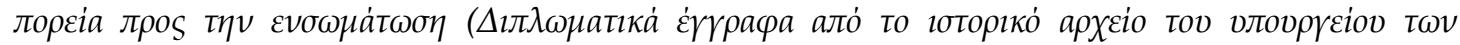

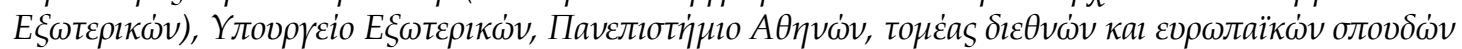

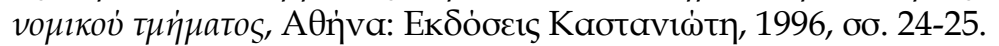

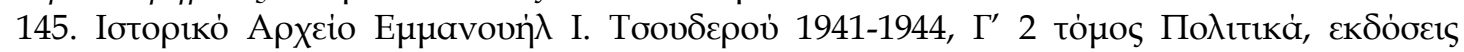
Фитра́кฤ, бо. 1283-1285. 
управа буде искључиво британска, Цудерос се вратио на свој захтев након 1. марта 1943. године, надајући се најповољнијем резултатуํ․․ Ови покушаји су неуспешно окончани одбијањем грчког предлога, од стране британских надлежних органа, да се ангажује у управи Додеканеза један познати грчки држављанин који води порекло са острва. Разлог је био грчко држављанство кандидата ${ }^{147}$.

Избегличка Грчка влада је уграбила шансу за још један допис којим је изражавала јако противљење према британским властима. У том документу се истицало то да је „Грчка влада изненађена помињем Турске у случају Додеканеза, а још више што на крају изгледа да има исти третман као и Грчка по овом питању... Турци немају друга права на Додеканезу сем освајача, која су и уступили Италији споразумом у Лозани из 1923. године “148. Међутим Форин Офис се није слагао са грчким ставом о ситуацији. У коментару Ласкија, из Јужног региона 31. августа 1943. године, наводи се: „Одговарајући Грцима, не желимо да се стекне утисак да стављамо турске захтеве испред њихових, али сматрамо потребним да их посаветујемо да би било добро да, у име грчко-турског пријатељства, не игноришу турске интересе ${ }^{\prime 149}$.

Све ово се дешава, и поред тога што је у августу 1943. године турски амбасадор на Средњем Истоку званично изјавио Цудеросу да

146. F.O. 371/37194/R 1871. Цудерос уручује Идену aide-memoire који се односи на грчке територијалне претензије и предлаже да учествују јединице грчких оружаних снага у

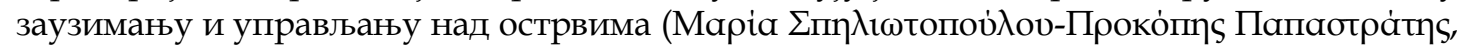

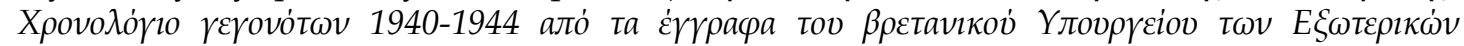

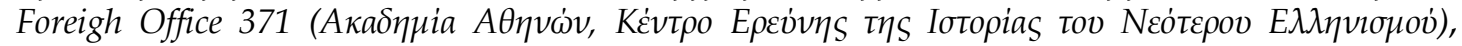

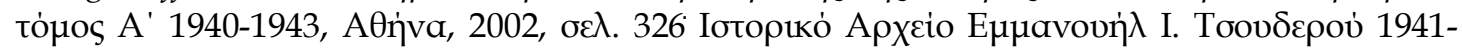
1944, $\Gamma^{\prime} 1$ то́

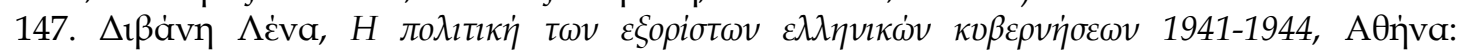

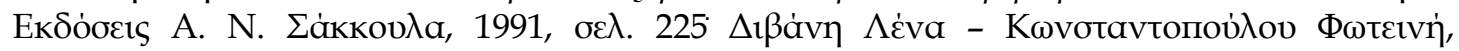

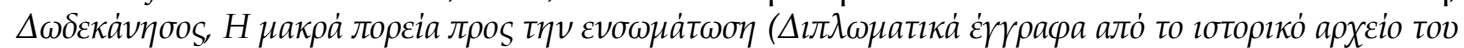

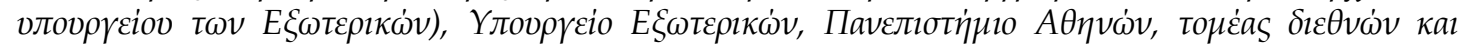

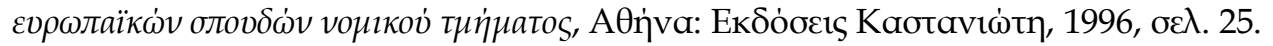

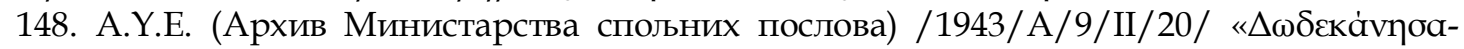

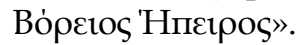

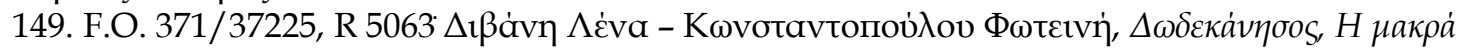

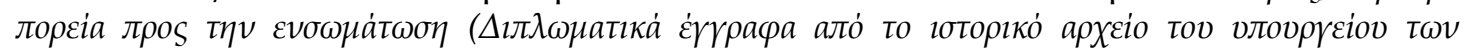

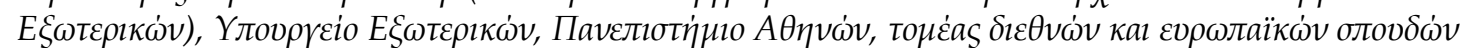

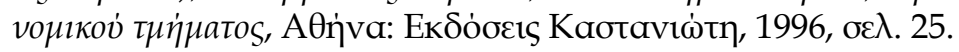


„Турска нема територијалне претензије у овом рату“150. Навешћемо да су у том периоду дата упутства BВС-у да се Додеканез не назива грчком територијом, али да се не забрањује помињање грчког порекла његових становника151. У септембру 1943. године је искрсао још један проблем који је изазвао бес Грчке владе. Врховни командант Средњег Истока, поред предлога Предводника Одреда за ангажовање грчке војске на Додеканезу, није био сагласан са тим, сматрајући да би то отежало њихове везе са Италијанима, чијој помоћи су се надали да би задржали острва ${ }^{152}$. Било је тешко прихватљиво за Грке да посматрају Италију како претендује на место савезника. Како би се смирила ситуација Форин Офис је поверио Липеру да објави Грчкој влади да је за сада прихваћено учешће једне војне трупе тзв. Јерос Лохос у операцијама. Што се тиче управе над острвима, и поред тога што је предвиђено да ће бити у потпуности британска, Ратни Савет се сложио с тим да се одреди један грчки саветник британског управника, ако се томе не успротиви Врховни командант Средњег Истока ${ }^{153}$.

Међутим, ништа од ових планова није остварено, будући да је у првој половини октобра 1943. године Додеканез освојен од стране немачких снага, и био је међу задњим грчким територијама које су се ослободиле. И поред овога, британски ставови су остали непромењени у складу са одлуком донешеном на јесен 1943. године, где је Форин Офис одбијао до краја, поред притиска свих Додеканеских организованих тела

150. Наравно да је у разговору Цудероса са турским амбасадором у Каиру, у августу 1943. године, последњи показао страх да ће Русија проследити Бугаре на европску обалу Дарданела и она би долазила возом до Егеја, користећи можда слободну зону Солуна. Турчин је такође званично подржао потребу блиског пријатељства између две земље. Свакако е успео и да изјави да би Турска са задовољством гледала да подржи Грчку да се настани на европској обали Дарданела него у другој држави, ако би на овај

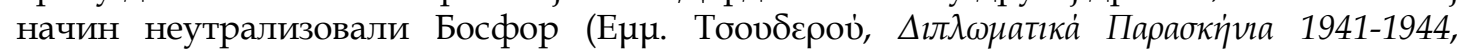

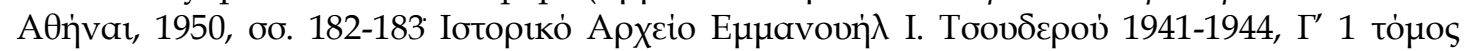

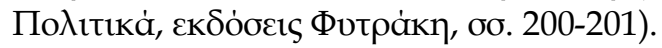

151. F.O. $371 / 37212$, R 8173 .

152. F.O. 371/37226, R 9039 кан R 9058.

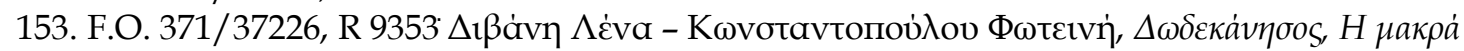

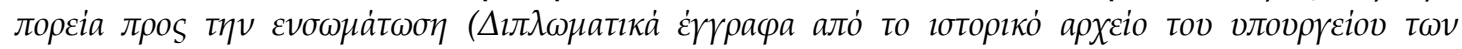

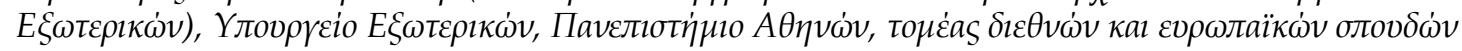

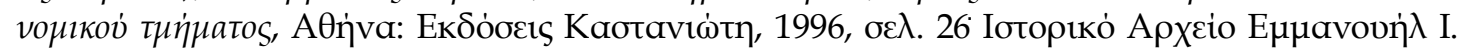

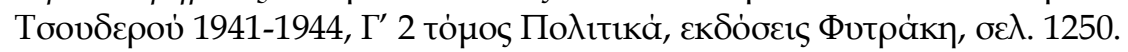


и избегличке владе, да разговара о будућем режиму над острвима пре завршетка рата ${ }^{154}$. Остали су верни ставу „нема разговора о територијалним питањима док траје рат“, чак и када је у пролеће 1944. године, веома ослабљена из совјетско-пољских разговора о границама и преговорима у вези са уступањем Трансилваније Румунији ${ }^{155}$.

Додеканез је био једина од грчких националних претензија која је имала потпуно успешан завршетак по грчку страну. Годину дана након ослобођења Грчке од Немаца, Савез Министара Спољних Послова у Лондону је признао да Додеканез треба да се додели Грчкој156. Влада Цалдариса, која је произишла из бурних избора 1946. Године, учинила је велике покушаје да истакне питање грчких националних претензија. Додеканез је на крају представљао једини Цалдарисов успех на дипломатском пољу 157 . Њихово уједињење са Грчком се озваничило Споразумом у Паризу у фебруару 1947. године 158.

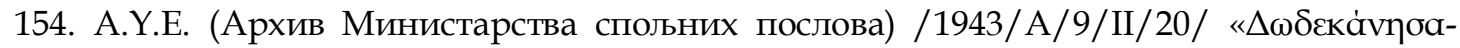

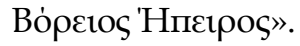

155. F.O. 371/43755, R 5118.

156. Детаљније о меморандуму грчког Министарства Иностраних Послова упућено Савету пет министара Спољних Послова у Лондону у вези са организовањем Конференције о миру са Италијом види А.Ү.Е. (Архив Министарства спољних послова)

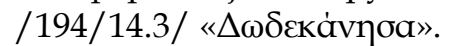

157. О дипломатским покушајима за уједињење Додеканеза са Грчком након завршетка рата види S. Хуdis, Greece and the great powers 1944-1947, Institute for Balkan Studies, Thessaloniki, 1963, pp. 196-214.

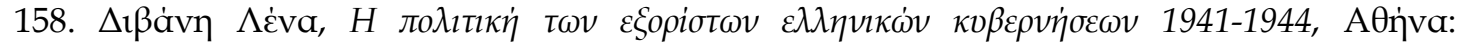

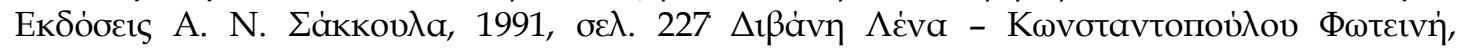

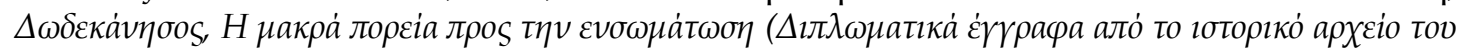

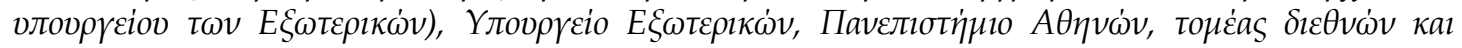

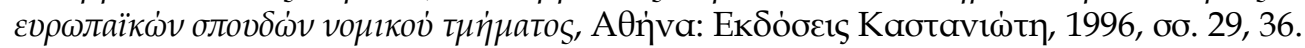




\section{8 КИПАР}

Кипар је уступљен Великој Бритганији од стране Турске, 4. јуна 1878. године, потписивањем тзв. Кипарског споразума. Овај гест, и поред негодовања Султана, био је уздарје Турске за подршку коју им је Енглеска пружила за време руско-турског рата. У складу са овим тајним уговором, Енглеска би преузела управу над „великим острвом“ у замену за обавезу да изнова подржи Турску у случају да Русија буде имала територијлалне претензије наспрам аутократије. Другим речима, то је било више једно „дугогодишње изнајмљивање“, него уступање територија. За Енглеску је то било једно сасвим задовољавајуће решење, с обзиром да је тражила једну погодну базу на Средњем Истоку. Међу стратешким циљевима Енглеза било је освајање Калиполија, па чак и целе области Босфора. Међутим, Кипар и Александрета су се на крају показали као два најбоља решења. Најбоље решење од ова два је био свакако Кипар, зато јер је његова одбрана могла да се организује много ефикасније, и зато што друге велике силе не би показале противљење ${ }^{159}$.

Грчка, која се већ налазила под утицајем Британије, била је задовољна што је Кипар прешао у британске руке. Постојала су два основна разлога за то задовољство. Први је био тај што ово острво, без обзира на то да је у свести Грка оно било несумњиво део велике Грчке, још увек није било циљ грчке спољне политике, која је тада имала тежњу за проширењем граница ка северу. Други разлог је био тај што је грчко државно вођство увек веровало да ће Енглеска у неком повољном тренутку добровољно уступити острво Грчкој, као што је учинила 1863. године са Ептанисом (група острва на Јонском мору), која су дата као мираз Краљу Георгиосу I. Чињеница је да од тренутка када је Кипар прешао под британску контролу, Грци са Кипра су често показивали ову

159. У вези са британским погледима у области види G. D. Clayton, Britain and the Eastern

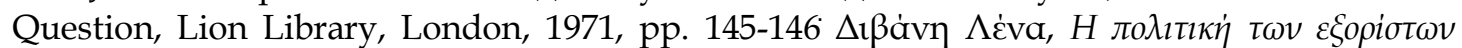

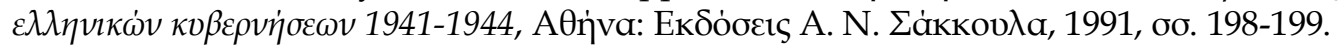


тенденцију и исказивали жељу за уједињењем са матицом, и 1898. године основали су удружење са седиштем у Атини са овим циљем.

У новембру 1912. године упућена је, на неки начин незванично, прва понуда Кипра Грчкој од стране Лојда Џорџа његовом пријатељу и конзулу Грчке у Лондону, господину Ставридису160. У питању је била нагодба, где би Британци дали Кипар у замену за добијање олакшица у морском саобраћају и лучким снабдевањем у случају рата на неком Јонском острву близу Јадрана. Венизелос је, после много размишљања, прихватио понуду ${ }^{161}$. Овај договор, међутим, није напредовао због важнијих питања која је наметнуо грчко-бугарски рат. Двојак режим на Кипру је окончан у тренутку када је Турска ушла у Први светски рат, а Енглеска је тада припојила острво. Венизелос је, понешен јаким осећајем патриотизма, изјавио: „Овај догађај (припајање Кипра Британији) треба да се окарактерише као последња фаза националног препорода овог великог грчког острва. Према тајним информацијама информација које поседује Грчка влада, уједињење Кипра са Грчком ће се остварити ускоро“162.

Прва и једина званична понуда за Кипар се догодила 1915. године. Греј је, и име сила Савезника, понудио острво Грчкој у замену за њену помоћ Србији, тј. њен суштински улазак у рат. Међутим, тадашња влада Заимиса заједно са Краљем нису били вољни да изађу из неутралне позиције коју су у то време поседовали, и одбили су ову изненадну понуду са образложењем да би помоћ Србији у том тренутку имала лоше последице на грчки национални интерес ${ }^{163}$. У суштини, ова понуда је одбијена зато што Кипар, у том тренутку, није био главни приоритет

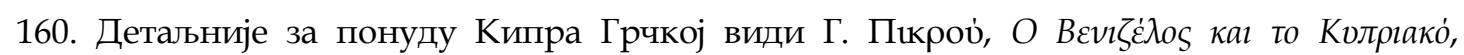

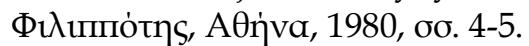

161. Његов проблем је био тај што он није знао ко ће бити у Влади када буде било потребно да Грчка уђе у предстојећи рат и није хтео да обавеже будуће власти (Г.

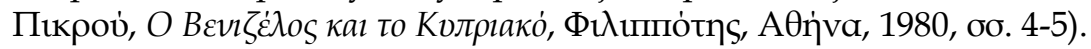

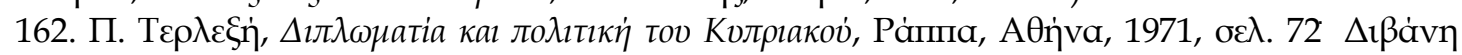

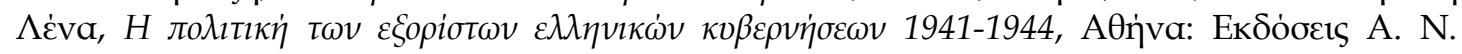

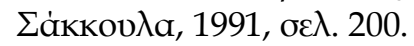

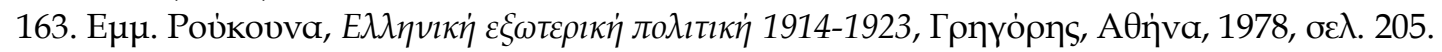


грчких интересовања. Напротив, питање Кипра сматрало се секундарним циљем у односу на Тракију, Смирни и Константинопољ, кључних области у грчкој империјалистичкој идеји. Када је Венизелос коначно донео одлуку да Грчка уђе у рат на страни Савезника, није покренуо питање Кипра јер је имао друге приоритете. До маја 1919. године је та тема остављана по страни, када је Лојд Џорџ предложио Савету Четворице да се Кипар додели Грчкој нешто пре малоазијске операције $\mathrm{1}^{164}$. Међутим, то у датом тренутку је било тешко изводљиво. Енглески парламент и конзервативци су негодовали на тај предлог, сматрајући да ако Грчка задовољи своје територијалне претензије ка Малој Азији, онда ће потпуно да заборави на Кипар. Дакле, предлагали су стрпљење по овом питању, као што се и догодило.

Малоазијска катастрофа која је уследила повећала је противљење енглеских служби када је реч о Кипру. Грчка није имала важне преговарачке „карте“ да би вршила притисак. Као што наводи Лојд Џорџ у својим мемоарима: „Венизелос је схватио да је Грчка због неодлучног става њеног Краља, изгубила свако право на територијалне уступке, које је обећао Греј у замену за грчку подршку“165. Штавише, Споразумом из Лозане, тачније чланом 20 истог, Турска је коначно и званично одустала од сваког њеног сувереног права на острву. Кипар је 1925. године припојен Краљевској колонији и високи комесар је постао гувернер. То је значило да Британија више није преговарала за Кипар, док је његова стратешка вредност скочила због активности коју је Италија показала за све време трајања рата у Средоземљу.

Што се тиче грчких влада које су се формирале између два светска рата, а посебно под премијером Венизелосом, промениле су правац своје спољне политике. Шок који је Грчка доживела услед малоазијске катастрофе и њених последица, судбоносно је довело до промена и

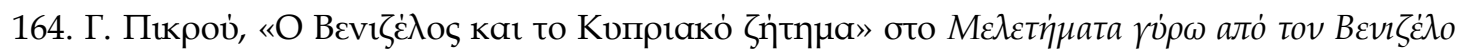

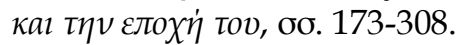

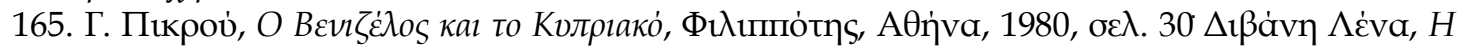

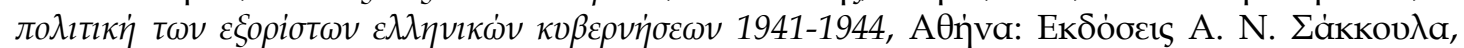

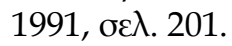


избегавања нереалних циљева. Нове границе Грчке су прихваћене такве какве су, и колевке хеленизма, као што су Додеканез и Кипар нису више представљале циљеве грчких претензија. Венизелосова теорија је била да је тог тренутка најпрече питање било јачање међународног положаја земље и њене преговарачке позиције. Како би успео у овоме, одлучио је да примени отворену дипломатију која је подстрекивала добре и обострано јасне односе са свим „заинтересованим“ земљама - Енглеском, Француском, Италијом, Турском и осталим балканским земљама. Тако је, зарад добрих односа у том периоду са Италијом жртвовала Додеканез, а са Енглеском Кипар. Карактеристична је његова изјава из 1928. године „да Кипарско питање треба решити између самих Кипрана и британских власти, а не између британских и грчких власти“166. Доследан овој изјави, Венизелос је за време грчко-кипарске побуне 1910. године сматрао да Кипрани праве грешку што не претендују законским средствима за повећавање својих слобода ${ }^{167}$. Јасно је ставио до знања конзулу Грчке А. Киру, великом поборцу Уједињења, да „Грчка влада неће покренути дипломатске потезе у Лондону за Уједињење “168.

Питање Кипра је поново покренуто у току трајања грчкоиталијанског рата. Грчки успеси су пробудили патриотизам код Кипрана. Уз подршку свештенства, које је дало велико црквено богаство за националну борбу, око 1.200 кипарских регрута је покушало да пређе у Грчку и да се сврстају у њену војску. Овај подухват је дао повод за разговоре о овој теми у Форин Офису. Британски амбасадор у Атини, Сер Ц. М. Палерет није био противан идеји уступања Кипра Грчкој. Тако би се ојачало и савезничко јединство, које је у оним тренуцима било

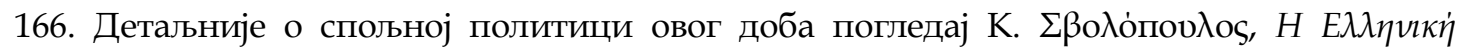

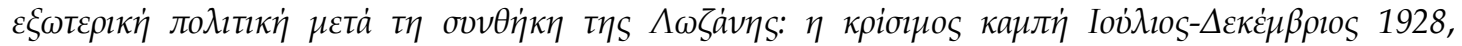

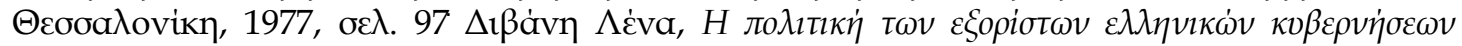

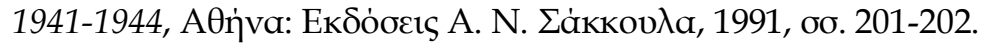

167. Према Пикросу, за побуну 1931. године крива је економска криза која је владала на острву, и коју је погоршавала британска економска политика. Такође, томе је допринела и чврст став грчког конзула Кироса, великог поборника уједињења, као и жеља земљорадника да искористе пољопривредне реформе у Грчкој. (Г. Пикрој, О

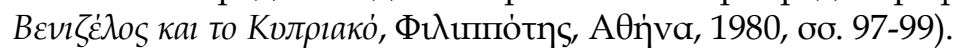

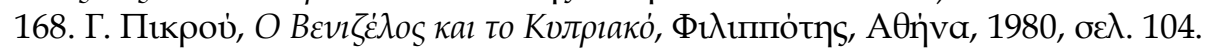


неопходно. Саветници Форин Офиса, Ворнер и Диксон се такође нису противили, под условом да се Великој Британији уступи војна база у Суди. Супротно мишљење је имао Николс, који је веровао да би сваки разговор о Кипру удаљавао Турску од савезништва. Овог мишљења је био и стални заменик Министра спољних послова О. Саргент, који се побринуо да то да до знања и Палерету. Поручио му је да притисне Грчку владу да не прихвати кипарске регруте у своју војску. Како би били сигурни у томе, британске власти на острву су хапсиле све оне који су покушали да избегну без пасоша ${ }^{169}$.

Први јасан потез Грчке по питању Кипра догодио се почетком марта 1941. године, када је Иден био у Атини на преговорима. Коризис, тадашњи премијер, му је рекао колико би величанствен био, у том кризном часу, један потез којим би Британија уступила Кипар Грчкој. Иден се тада успротивио да разговара о томе. Коризис је поновио свој предлог крајем истог месеца, истичући да би тај чин био драгоцен из психолошких разлога подизања морала. У наставку је разговарано и о могућности премештања Грчке владе на безбедну кипарску територију. Иден је још једанпут одложио такав разговор рекавши да ће, уколико затреба, направити план у Лондону о пребацивању владе ${ }^{170}$.

Нешто касније, 11. априла 1941. године, Краљ Георгиос је тражио од Палерета да дозволи да 4.000 мушкараца, који су се налазили на обуци на Пелопонезу, да заврше са својом обуком на Кипру. Такође је тражио да се, макар привремено, један део Кипра сматра грчким да би примио Грчку владу ${ }^{171}$. Палерет је 13. априла објавио Коризису да се Енглеска влада хитно споразумева са владом Кипра о смештању Краља и

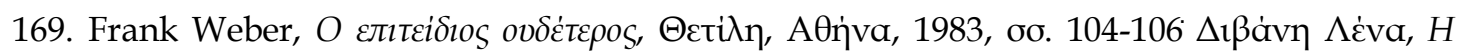

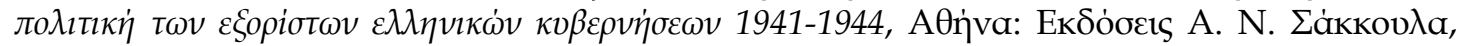
1991, oб. 202-203.

170. C. Svolopoulos, «Anglo-Hellenic Talks on Cyprus during the Axis campaign against

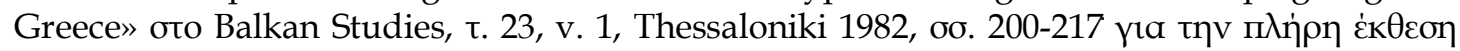

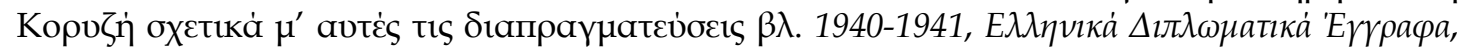

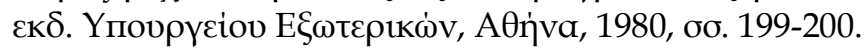

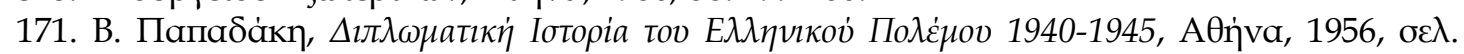
189. 
Грчке владе на острву уколико се остваре предвићени предуслови. Додао је да би у том случају, положај Грчке владе био третиран исто као положај осталих савезничких влада које су смештене у Енглеској, и да Британска влада не разматра предају дела острва ${ }^{172}$. Грчки премијер му је одговорио да Краљ и влада не сматрају ово решење задовољавајућим. Инсистирали су да им се додели један мали део Кипра, да Краљ достојанствено може вршити своју дужност. У супротном ће се преместити на неко друго грчко острво, не марећи за опасности којима ће бити изложена.

Британски Ратни Савет је, 14. априла 1941. године, размотрио ово питање. Највише негодовања је показао надлежни Министар Колонија, аргументујући да уколико се уступи један део Кипра, било би веома тешко после да се сузбију охрабрене наде оних који су желели уједињење. Грчка влада је и овог пута добила негативан одговор, и касније се пребацила на Крит. Али убрзо се и тамо нашла у несигурном положају. Врховни командант сер Б. Фрајберг је сматрао да Грчка избегличка влада треба да се пребаци одмах из два разлога - да се не излаже опасношћу, а и зато што је њено присуство унутар ратне зоне било непримерно, пошто је генерална команда припадала Савезничком Штабу.

Форин Офис је, супротно овоме, сматрао позитивним што дужи боравак Грчке владе на Криту како би се ојачао морал борбених Крићана. Иако је привремено преовладало мишљење Форин Офиса, разговор о премештању владе је био настављен. Почетком маја, Цудерос je предложио Палерету премештање владе на Кипар. Његово размишљање је било да би овај чин морално подигао нацију и представљао би један јасан наговештај за послератну судбину острва ${ }^{173}$. Енглески амбасадор је одговорио да се овакво решење не препоручује,

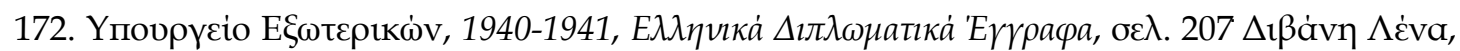

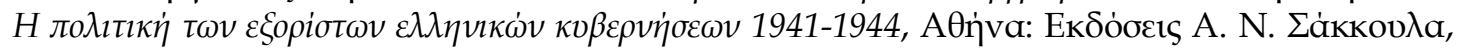

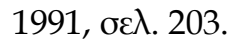

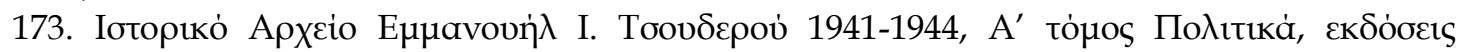
Фитра́кฤ, бо. 22-23. 
јер би то могло довести до немачког напада на Кипар који је био незаштићен ${ }^{174}$.

Приметно је да су Британци у том тренутку били јако опрезни по питању Кипра. Док су исти средином априла прихватили идеју једноставног настањивања владе на Кипар, касније су се бојали да ће један такав подухват да се протумачи као повод за рат (casus belli). Још су опрезнији што се тиче идеје о уступању Кипра, или једног његовог дела, као награде борбеним Грцима. Главно питање је зашто су били противни овој идеји, кад у складу са британским анализама тог доба, уступање Кипра Грчкој није штетило интересима Велике Британије, нити је претило безбедности аутократије. У званичном допису из 31. маја 1941. године, британског Министра спољних послова Идена упућеног Ратном Савету каже се да „једине препреке за уступање острва Грчкој су споразум из 1916. године, који је потврђен чланом 4 из францускобританског уговора из 1920. године, према којем Француска може да стави вето на уступање острва трећој сили, и права Турске на острву са стратешког гледишта и на основу тамошње турске мањине. Први разлог се у датом тренутку тешко може сматрати за озбиљним, имајући у виду да је Француска великог брзином губила свој положај у Сирији. А што се тиче другог разлога, могле су да се предузму мере тако да се заштите стратешки интереси Турске, и да се реши проблем турске мањине премештањем становништва“"175.

Одговор на ово питање је да Велика Британија није хтела да свој живот учини тежим са савезницима у тим кризним тренуцима рата. Ако би уступила Кипар, могуће је да би то изазвало незадовољство Турске, чију је помоћ желела да обезбеди. Како би прекинули разговоре на ову тему, усвојили су доктрину „нема разговора о ниједном територијалном питању док се рат не оконча“ и то су јасно показали заинтересованима.

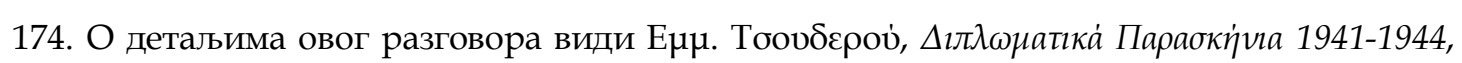

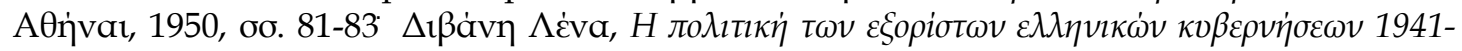

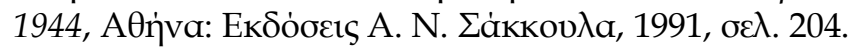

175. Овај меморандум под насловом «The future of Сурrus» поднео је Иден 31. маја 1941. године (War Cabinet papers, (41) 118-119). 
Цудерос је од тренутка одбијања понуде коју је био изнео на Криту, схватио овај британски став за озбиљно. „Вероватно питање Кипра није још сазрело“, бележи у свом личном дневнику176. С обзиром на невољност Британије, проблем је за Цудероса постао много већи. Требао је да агресивно потражује део територије која припада држави домаћину, заштитнику и савезнику, одакле је он исти црпео своју власт, а тако нешто је тешко било игнорисати. Одлучио је да испроба границу издржљивости система пажљивим потезима.

Кипарско питање се по први пут званично поменуло у писму које је Цудерос упутио Краљу Георгиосу у јуну 1941. године, путујући ка Јужној Африци. Ово писмо, које је садржало потпуну слику његових размишљања о садашњости и будућности Грчке, између осталог, разјашњава грчке националне претензије, као и документацију која је имала Грчка за ове територије. Део који се односи на Кипар је гласио: „На крају о Кипру, осим познате понуде острва Заимису 1915. године, постоји и изричита одредба у Грчко-италијанском споразуму из Севра, од 10. августа 1920. године, која је потписана под покровитељством Савезника, о будућем уступању Кипра Грчкој, као и да би Италија била у обавези да уступи Родос након референдума“"177. Ово је написао у свом меморандуму упућеном Краљу Георгиосу. Међутим, када му је нешто касније, у септембру 1941. године дата шанса да разговара са Кадоганом из Форин Офиса о питању националних претензија, настојао је да се усмери на Додеканез и Северни Епир, избегавајући вешто Кипарско питање ${ }^{178}$.

Цудерос је, месец и по дана касније, одлучио да направи један мали корак напред. На ручку који су Грци приредили у Лондону, 15. новембра 1941. године, Цудерос је песнички и алегорично говорио о

176. Необјављен дневник Ем. Цудероса у библиотеци Генадио.

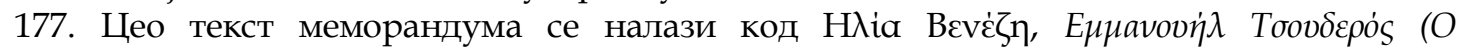

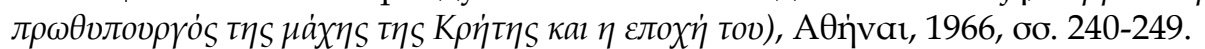

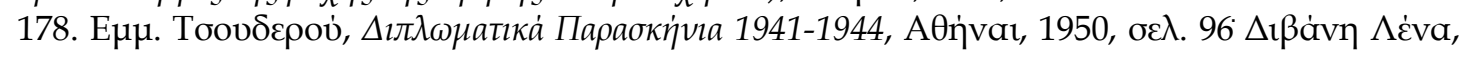

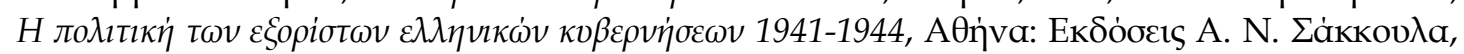

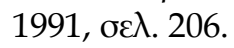


националним претензијама државе. Посебно је нагласио следеће: „Није сама (Грчка). Праћена је од стране својих вољених и усамљених ћерки. Препознају се лако према одећи коју носе: ево Македонке, Крићанке, Кипранке, Пелопонескиње, Додеканескиње, Североепироћанке... украшене с ловором, прате своју мајку која иде напред, према победи, која ће их поново спојити у миру“179. ВВС је емитовао кратак садржај свега што је рекао Цудерос, док се кипарска штампа веома детаљно позабавила овом темом, што је било и логично. Пометња која је изазвана овим једноставним помињањем имена острва од стране Цудероса, је дало прилику Турској влади да протествује, верујући да је Форин Офис охрабрио Цудероса да да овакве изјаве. Турско-кипарски лист „Соз“ је, 19. новембра 1941. године, написао у главном чланку: „Ове изјаве су изазвале велику забринутост и тугу у турским јавним круговима и очекује се, с великим нестрпљењем, демант ових мишљења од стране британских власти“180.

Иден је 17. новембра 1941. године позвао Цудероса на разговор у Форин Офису. Том приликом га је љутито осудио да је унео немир у један део аутократије. Иден је нагласио Цудеросу да је помињање Кипра у његовом говору кипарској заједници у Лондону 15. новембра изазвало белику нелагодност Британској влади. То је објављено и у кипарским новинама, и гувернер се веома забринуо. Неопходно да се објави саопштење на Кипру, које ће појаснити да се не врше преговори између две владе о Кипарском питању. Цудерос је одговорио да је његов говор био химна британске колонијалне политике, и да се односио на послератна догађања. Цудерос објашњава да се једноставно обратио песничким језиком мученичкој Грчкој која је праћена својим кћерима, међу којима се налазе Кипар и Грчка Македонија. Такође је рекао да питање Кипра неће покренути сада, али са задовољством ће то учинити након завршетка рата. Сматра да Грчка има јаке разлоге да буде 
оптимистична у вези са питањем Кипра на основу Атлантске Повеље ${ }^{181}$. Иден му је скренуо пажњу да не помиње инсинуације ове врсте у његовим будућим јавним говорима. Разговор је завршен Иденовом изјавом да hе се свако покретање ове теме бити сматрано јако непријатним за Британску владу ${ }^{182}$. Да би се ово питање разрешило гувернер Кипра је, 1. децембра 1941. године, објавио да уступање Кипра од стране Енглеске Грчкој после рата није у разматрању.

У вези са Цудеросовим говором у грчкој заједници у Лондону 21. августа 1941. године, Саргент сматра да је прерано да покрећемо питања територијалних уређења, и да о овим питањима би требало да се разговара после рата ${ }^{183}$. Цудерос је одговорио у писму Саргенту, 23. децембра истог месеца, да уопште није преурањено и да је то веома значајна тема за Грчку. Такође је рекао да када Грчка говори о Северном Епиру и Додеканезу не покреће питање територијалног уређења или утврђивања граница, него посматра одређене територије на исти начин као на територије остатка Грчке и наглашава да Грчка има за право да поврати области које су јој одузете ${ }^{184}$. Верује, такође, да треба да се предузму мере како би се суочили са упорном непријатељском пропагандом која се односи на ову тему. То се односи на његов сусрет са Иденом 25. новембра, и наглашава да саопштење Британског гувернера Кипра није у складу са истином, када наводи да никада нису вођени преговори о Кипарском питању. Краљ Георгиос II обавестио га је да су о

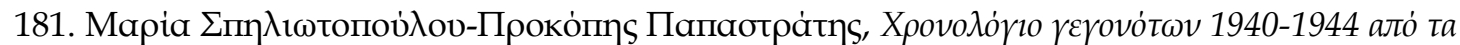

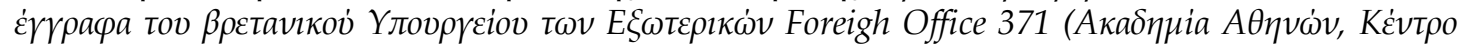

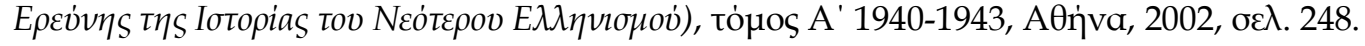
182. F.O. 371/29838, R 10333.

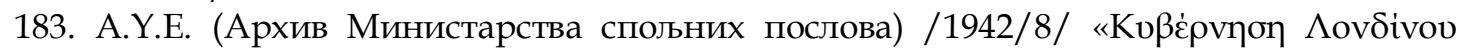

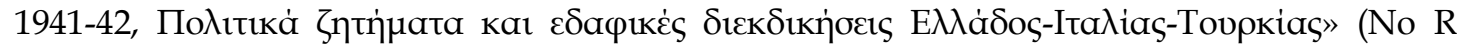
I0236/534/90, F.O., S.W.I.).

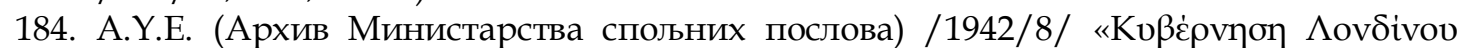

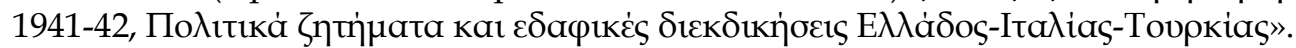


том питању разговарали Иден и Коризис почетком 1941. године и да је договорено да се разговори наставе после рата ${ }^{185}$.

Цудерос се одлучио да се придржава приговора британске владе. Тако је 28. априла 1942. године, када је преко амбасаде у Лондону предао допис у вези са грчким националним претензијама Форин Офису, прескочио да сврста Кипар међу њима. Такође није одреаговао када су Министарсво Колонија и Форин Офис вешто блокирали иницијативу коју су били спремни да предузму грчки Кипрани у фебруару 1942. године. На предлог њиховог регрутовања у снаге грчке војске Британске власти одговориле да у тренутној фази рата, највећу услугу коју могу да понуде заједничком, светом, савезничком циљу је да дају све своје снаге за одбрану Кипра ${ }^{186 .}$

Ситуација се узбуркала неколико месеци касније, у јуну 1942. године, за време званичне посете Краља Георгиоса и Цудероса САД-у. Тада се Цудерос састао са Корделом Хулом, Министром иностраних послова САД-а и разговарали су, између осталог, и о грчким националним питањима. Међу њима се опет провукло питање Кипра. Наравно не као претензија, него као национала жеља, зато што се „ово острво на сву срећу окупира и просвећује од стране пријатељске земље“187. Како би заштитио себе, грчки премијер се побринуо да копију свог разговора упућен Американцима проследи британском амбасадору у Вашингтону, Д. Ц. Халифаксу, заједно са дописом у којем се наглашавала да је упознат са тим да ће решење свих ових проблема уследити након завршетка рата и да је његова жеља да обавештава о свему Британску владу. Форин Офис је сматрао претераним овај Цудеросов потез, јер никада им се није званично поставила таква тема на разматрање. Д. Диксон из Јужног сектора је саветовао: „Мислим да на

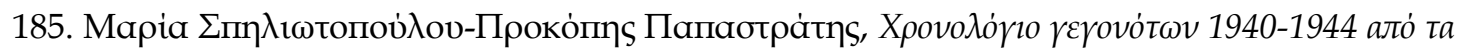

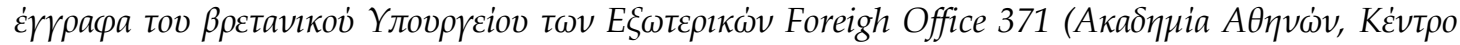

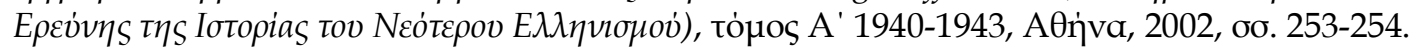

186. F.O. 371/33172, R 1391.

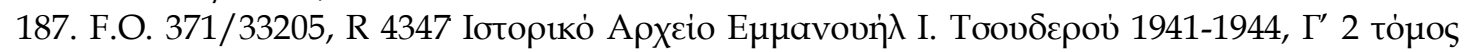

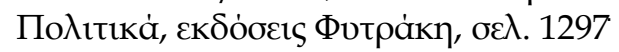


учтив начин треба да искритикујемо Цудероса који је прешао границу са Американцима, и разговара о уступању Грчкој једне британске територије“188. Заиста, када је завршено путовање грчких званичника, Палерет им је указао на незадовољство Британске владе и прихватио је Цудеросова извињења. Међутим, разлог што је Цудерос покренуо тему о Кипру са америчким властима, поред проблема којих се бојао да ће произићи, био је била морална и свака друга подршка коју је грчкоамеричка заједница САД-а показивала у вези са Кипром. Овај случај је учинио да Америчка влада буде наклоњена повољном решењу што се тиче грчког захтева, с обзиром да је америчко јавно мњење одувек имало аверзију према империјалистичкој политици Британаца ${ }^{189}$. Међутим, у наставку је ова тема изгубила на значају 190.

Потпредседник владе П. Канелопулос је преузео на себе да мало узбурка воде неколико месеци касније, јер није посебно ценио политику „великог стомака“. У децембру 1942. године, док је избегличка влада била узнемирена кризом коју је проузроковала британска изјава о независности Албаније, Канелопулос је саставио телеграм за Идена. У телеграму се каже да, како би остао у влади да би он (Иден) требао да да једну изјаву у вези са ослобођењем свог грчког становништва после рата, наводећи изричито Додеканез и Кипар. В. Е. Мојне, који је прочитао телеграм, га је посаветовао да то не пошаље како би избегао неспоразуме. Канелопулос му је љутито одговорио да ће послати телеграм и поред његових савета, зато што Велика Британија не разуме да је од круцијалног значаја за грчки народ ${ }^{191}$. Иденов одговор је стигао 23. децембра 1942. године: „Разлози високе политике намећу Енглеској да не

188. F.O. $371 / 33205$, R 4347.

189. Детаљније о извињењу Цудероса види 125-126. О ставу грчко-америчке заједнице према Кипарском проблему види извештај ОСС из 8. јула 1943. године («Documents: The OSS and the Greek-Americans» edited by E. Vlanton, Journal of the Hellenic Diaspora, summer 1982, vol IX, No 2, pp. 36-41).

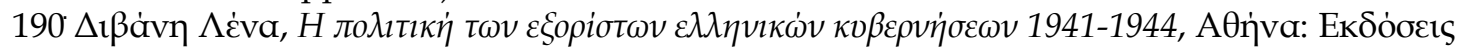

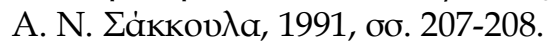

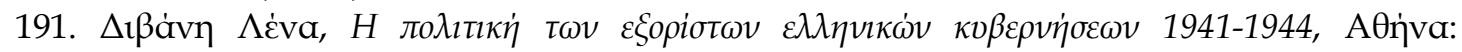

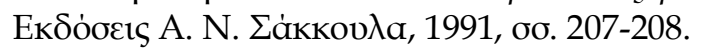


учествује ни у каквим јавним изјавама, нити у тајним обећањима“. Британско министарство Средњег Истока му је објаснило да су им руке везанне због проблема са Турском.

У међувремену, у фебруару 1943. године, Черчил је на кратко дошао на Кипар, враћајући се из Адане. У свом говору се похвално осврнуо на борбену Грчку. То се протумачило од стране кипарског хеленског становништва као охрабрење, и покренуло је разне иницијативе за уједињење од стране удружења, организација, новина и обичних грађана ${ }^{192}$. Британцима су засметала сва ова догађања, а посебно чланци из новина „ЕЛЛАС“ у Лондону, међу којима су постојали и чланци познатих Енглеза који су заступали идеју уједињења Грчке и Кипра. Због ових чланака, Саргент је послао телеграм 24. марта 1943. године грчком амбасадору у Лондону Агнидису: „Упознати сте са споразумом наших влада да се питање Кипра не покреће за време трајања рата. Такво јавно изражавање може само штету да нанесе. Такође побрините се да одговарате без обавеза на сваки телеграм с Кипра који се тиче уједињења"193. Агнидис му је одговорио да је позвао издавача новина и да му је скренуо пажњу да такви чланци не иду у корист нити Грчкој, нити Кипру194.

Нешто касније, у марту 1943. године, у Дому Лордова је рапсрављано о Кипарком питању са потпуно негативним ставом. Лорд Фарингтон је тврдио да Кипрани нису Грци, да никада нису били део старог грчког света. Једноставно говоре грчки језик. Такође је рекао да Кипар ништа не добија од уједињења са сиромашном и немоћном Грчком. Заменик Министра спољних послова за Колоније лорд Девоншир је говорио о враћању политичких и уставних слобода на острву после рата, али да није направио никакав наговештај о уступању

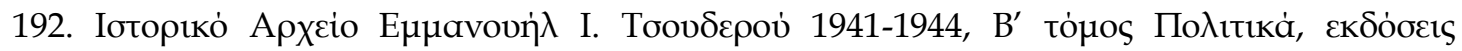

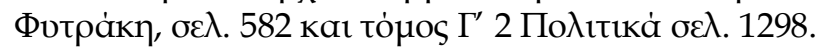

193. F.O. 371/ R 2488/464/19.

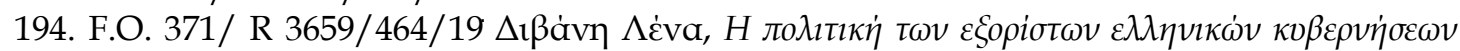

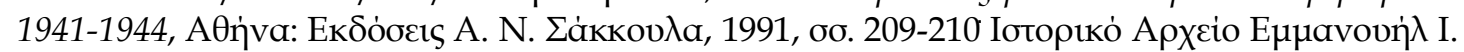

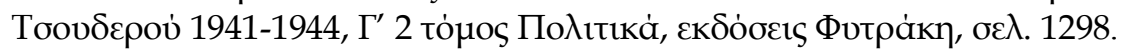


Грчкој. Ова расправа је изазвала узнемиреност кипарског хеленског становништва у Лондону и у САД-у, али избегличка влада није одреаговала' ${ }^{195}$. Њена потпуна зависност од Велике Британије јој није дозволила да покрене питање преузимања Кипра. Тако је Георгиос Папандреу, трећи премијер избегличке владе, у свом интервјуу на радију нешто пре пребацивања владе у Италију, у вези са националним претензијама, сасвим занемарио Кипар, како не би изазвао негативне реакције од стране Енглеза ${ }^{196}$. Папандреу је изјавио 1950. Године: „Данас Грчка дише с двоје плућа - једно је енглеско, а друго америчко, и из тог разлога не може, због Кипарског проблема, да буде у опасности да умре од гушења“197. Овај став званичне Грчке према Кипарском питању је дозволио Антонију Идену да након неколико година, тачније 1956. године, изјави Скупштини заједница: “Занимљиво је да се запази да се ова претензија (за уједињење Кипра са Грчком) није никада покретала за време рата. Постојале су грчке амбиције, али су се оне ограничавале на Додеканез“198.

195. Детаљније о разговору у Дому Лордова види. F.O. 371/37225, R 3765 Іоторєко Архсіо

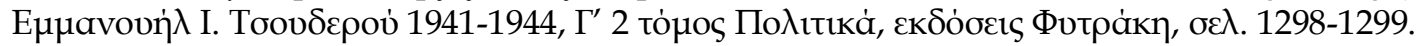

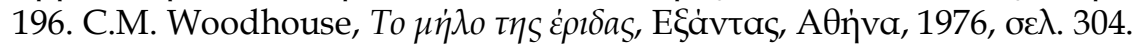

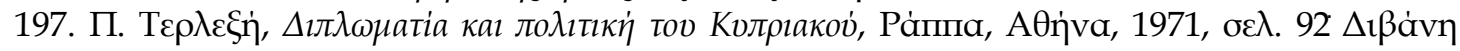

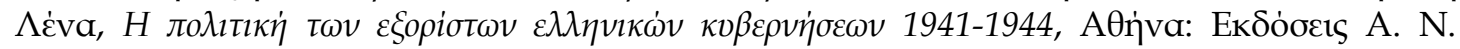

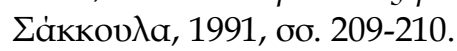

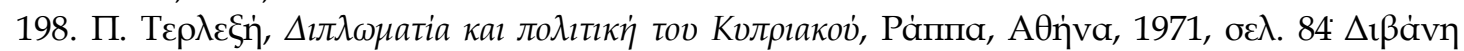

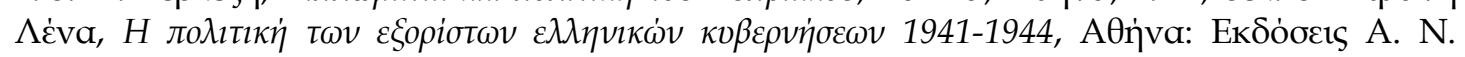

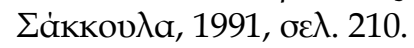




\section{ТРЕЋЕ ПОГЛАВЉЕ}

\section{ПОЛИТИКА ИЗБЕГЛИЧКЕ \\ ГРЧКЕ ВЛАДЕ НА БАЛКАНУ}

\section{1 ОКУПИРАНИ БАЛКАН И ПОЛИТИКА}

\section{БАЛКАНСКИХ ЗЕМАЪА}

Када је Грчка влада кренула путем избеглиштва, међу њеним приоритетима засигурно није било стварање јасне политике према Балкану. Била је свесна фактора зависности од земље која ју је примила, и чињенице да би у случају планирања своје стратегије, благовремено било потребно да се прилагоди захтевима Британског министарства иностраних послова.

Први је премијер Емануил Цудерос, у јуну 1941. године, одлучио да напише у једном званичном допису о изборима спољне и унутрашње политике његове владе и да обавести Краља с тим у вези. У поменутом допису наводи да је Грчка једна балканска, али првенствено медитеранска земља. Другим речима, смањује балканске димензије земље полажући своје наде првенствено у савезништво са Великом Британијом, из којег се надао да ће се створити нови услови који ће дати Грчкој право за остваривање великих територијалних претензија. Поводом тога Цудерос каже: „Досадашње искуство доказало је да је састав економије на Балкану такав, да је тешко остварљиво споразумевање међу народима у економском домену“199.

Међутим, нешто касније, када је Цудерос говорио о судбини Бугарске, мало је ублажио свој став. Подржавао је став да би најбоље решење за проблем бугарске агресије било да се ова земља примора да учествује у Балканској Унији, коју је Грчка замишљала као бесцаринску

199. У питању је меморандум који је Цудерос предао Краљу Георгиосу за време

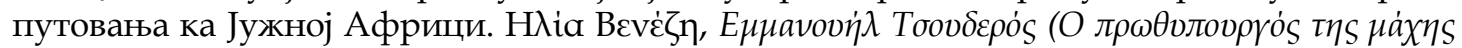

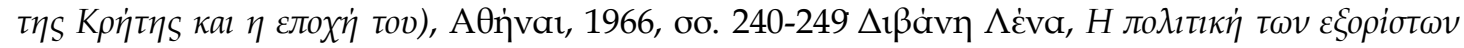

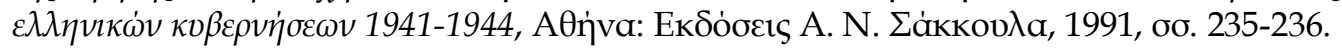


зону. Инсистирала је на бесцариснкој политици унутар Уније у нади да ће с тим да нестану све претензије суседа које су се односиле на слободне зоне и излазе на море. На крају је напоменуо у допису да је Грчка влада суштински супротна проглашењу заједнице Словена, тј. Југославије и Бугарске, као и свакој идеји која се односила на аутономију Македоније. Дакле, балканска политика Грчке из 1941. године, била је више негативна него позитивна, изражавајући углавном став шта не би желела да се догоди, него што је сама имала неку одређену визију.

Међутим, значајно је да видимо шта се у том периоду догађало у Британском министарству иностраних послова, јер ће то одиграти значајну улогу у развоју догађаја. На лето 1941. године, када се сазнаје у Форин Офису преко његовог амбасадора у Совјетском Савезу, да је СССР одштампао проспекте словенске пропаганде, одлучено је да се изврши мобилизација. Надлежним службама је поверено да истражи политичка, економска и социјална дешавања на Балкану, док се не уоче комплексни проблеми у региону и предложе решења ${ }^{200}$. Британци су имали велики страх од Совјетског Савеза. Они су веровали да, ако на крају рата победу однесе Совјетски Савез, тада је постојала опасност да цела Југоисточна Европа падне у њихове руке. Совјети би дакле тежили ка томе да претворе у своје сателите Бугарску и Румунију, од које желе да узму натраг Бесарабију и Северну Буковину, дајући заузврат Трансилванију. Што се тиче Југославије и Грчке, њихова будућност је такође неизвесна. Закључак који су извели Британци је био следећи - једини начин да не допусте Совјетском Савезу да неометано шири свој утицај на Балкану је постизање једног балканског споразума са учешћем Грчке, Југославије и касније Румуније и Бугарске 201.

Један такав пројекат балканских интеграција је изгледао као јединствено решење у том тренутку, како би се спречио совјетски утицај у региону. Један други сценарио, који се помињао у просторијама

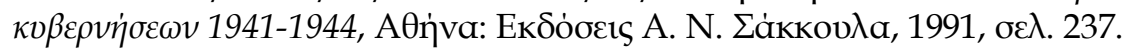


Форин Офиса, је било слање војске, али је било веома рано да се разговара о једној таквој могућности. Конкретније, Форин Офис је веровао да би једна Балканска федерација решавала проблем конкуренције међу народима у региону. Под тим се подразумева Југославија, која је била ослабљена због сукоба између српског, хрватског и словеначког становништва, као и мала и константно контролисана Албанија, која није била у стању да сама опстане. Такође, тиме би били прекинути планови о словенској превласти на Балканском полуострву 202.

Британци су на јесен 1941. године покренули разговоре о Балканском Споразуму са избегличким владама Грчке и Југославије, које су се тада налазиле у Лондону. Бугарска, Румунија и Албанија су само формално припадале Силама Осовине и још увек нису могле да се саме заступају, док је за учешће Турске постојао један проблем. Познато је да је Черчил жарко желео турско учешће у рату, како из стратешких, тако и из политичких разлога. Веома битан разлог је био постојање још једне војске, поред совјетске, када је требао да крене ослобађање Југоисточне Европе 203 . Велика Британија је тражила учешће Турске у Балканској Унији, надајући се да ће то створити позитивну атмосферу сарадње са савезницима и на тај начин је подстакне да се укључи у рат ${ }^{204}$. Насупрот томе, изгледало је да је Турска заинтересована за придруживање унији, али тек након завршетка рата. Преговори нису завршени успехом из више разлога. Један од њих је био и тај што, нити Велика Британија, нити Грчка, нису биле разјасниле које би тачно било турско учешће у евентуалној унији. Цудерос је у вези са овим питањем изразио бојазан да би, као азијска држава, могла да их уплете у проблеме Средњег Истока205. Још један негативан фактор су били страхови Југославије да би Грчка и Турска играле водећу улогу у Балканском Савезу, придајући један

202. F.O. 371, R $10471 / 113 / 67$.

203. Adam Vlam, Expansion and coexistence, the history of the Soviet foreign policy 1917-1967, Secker and Warburg, London, 1968, p. 346.

204. F.O. $371 / 33134$, R 8380.

205. F.O. 371/37179, R 2303. 
антисловенски карактер и изазивајући тиме реакцију Совјета ${ }^{206}$. На крају, не треба занемарити да став који је имала Турска за све време трајања рата, под паролом „разговарај, али не преузимај обавезе“, није помогао развоју догађаја 207.

206. F.O. 371/R 5081/1551/67. Форин Офис није придавао велик значај југословенским притужбама. Напротив, изгледала им је веома привлачна идеја једне Балканске Уније, која би била брана великословенских визија..

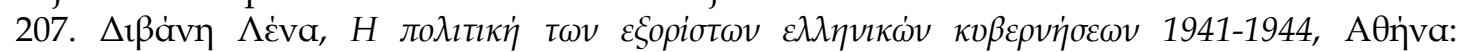

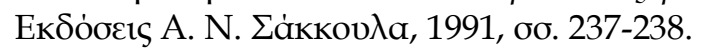




\section{2 ГРЧКО-ЈУГОСЛОВЕНСКИ ОДНОСИ}

\subsection{1 РАЗМИШЉАҢА И ОДЛУКА ГРЧКЕ ВЛАДЕ ДА СТАВИ ПОТПИС НА ГРЧКО-ЈУГОСЛОВЕНСКИ СПОРАЗУМ}

Садржај грчко-југословенског споразума који је представљен Грчкој влади, сматран је пре свега нејасним и безопасним. Ни у једном случају није се радило о Балканској федерацији, за чије формирање Председник Грчке владе није био присталица. Предложени текст споразума је имао многе сличности са Балканским Споразумом, али по мишљењу Цудероса, био је нешто више од тога. Текст који је требао да буде потписан од стране Грчке и Југославије, био је отворен и за остале балканске земље.

Прво питање које се појавило, било је питање Турске. Југословени су предложили да се Турска влада обавести о тексту споразума и о намери двеју земаља да га потпишу. Грчки председник је сматрао да би било у грчком интересу да се избегне учешће Турске у Унији. Новооснована Унија би могла касније, ако је то у њеном интересу, да склопи савезништво са Турском. Турско учешће од самог формирања је, према Грцима, требало избећи да Турска не би имала претерани утицај на Унију. Након распарава о овој теми, већински је подржан став да би било у интересу Грчке да Турска буде присутна у Унији. Њено присуство у Унији би функционисало као противтежа могућег словенског утицаја, под којим би могла да потпадне Унија208.

Председник Грчке владе Е. Цудерос у својој поруци, намењеној Министру спољних послова Југославије М. Нинчићу 4. фебруара 1942. године, у вези са Балканском Унијом, наводи следеће: „У његовом говору за време ручка 15. јануара 1942. године, његово Височанство Краљ Петар је поменуо могућност будуће сарадње између Балканске Уније и држава

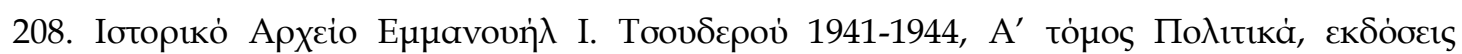
Фитра́кฤ, бо. 350-351. 
Централне Европе. Ова идеја је поновљена и јавно, неколико дана касније, од стране председника Бенеша за време ручка у част Његове Висости Краља Петра. Свака идеја је вредна пажње и не бих желео да је оспоравам. Међутим, ако би данас постављали ово питање, изразио бих озбиљне сумње о томе, што се тиче интереса балканских држава. Идеја уједињења балканских држава није била нова. Постоји већ 30 година, још од 1912. године, тако да грчка политика не може да буде сматрана освајачком од било кога, или да буде схваћена као одговор на експанзију њеног савезника Русије. Дужни смо да усредсредимо сву нашу пажњу на ове могуће развоје ситуације, зато што није у нашем интересу да Унија изазове и најмању сумњу у овом смеру, и да за последицу имамо неку спољну реакцију. Треба да је заштитимо од ове опасности, и имам разлоге да верујем да је од стране Русије постојала сумња за могућу сарадњу наше Уније са Пољском и Чехословачком. Реално, ако су наша Унија и Унија држава Централне Европе хтеле да се повежу у овом тренутку, створила би се опасност да се код Руса изазове утисак да остварујемо «le cordon sanitaire» (безбедносна зона)“209. Циљ Балканске Уније је да служи очувању мира на Балкану. Један значајан допринос овом циљу би било унапређивање уских пријатељских односа између Балканске Уније и Велике Британије, нарочито по питању Средоземља, као и побољшање односа са Русијом и другим суседима Уније.

Очигледно је да Цудерос у том тренутку не може знати какав ће бити исход рата, и која изненађења може да крије. Међутим, док га ова помисао чини да буде веома опрезан, није противан томе да се потпише један уопштен „споразум безбедности“, који би трајао петнаест година од потписивања мира, под покровитељством великих савезника, међу свим малим државама Европе које се налазе под непријатељском окупацијом, зато јер један такав споразум не би могао да се окарактерише да има освајачке циљеве. Његов циљ би био да обезбеди

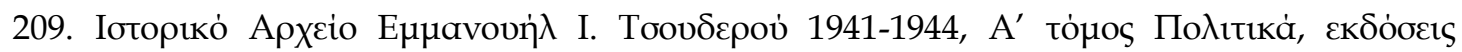
Фитра́кฤ, бо. 463-464. 
мир међу европским земљама, које су окупиране од стране Немачке, кроз изјаве међусобне заштите против сваког напада. Тако би изрекли своју жељу да убудуће живе у миру, далеко од сукоба. Ако све земље обострано гарантују за мир, у том случају ни једна држава неће моћи да сматра да је у питању један споразум који је окренут против неке велике силе. Насупрот томе, један такав неосвајачки карактер не би могао да се припише безбедносном споразуму између Балканске Уније и Уније Држава Централне Европе.

Што се тиче грчких односа са Турском и на грчку политику према њој, Цудерос жели да између две државе постоје што је могуће бољи и приснији односи, као и да се повежу уговором шире сарадње. Међутим, он сматра Турску претежно азијском нацијом и чврсто верује да би озбиљно требало размислити о томе да ли је у интересу Балканске Уније да Турска буде умешанана у једном удружењу европских земаља. Од тренутка када тај уговор говори о европским границама Грчке, под знаком питања је колико Турска заиста има интерес да учествује у Балканској Унији ${ }^{210}$.

Споразум обнавља историјске односе Грчке и Југославије и њихове жеље за ближом сарадњом у наставку рата, као и пружање узајамне подршке у току мировних преговора. Очигледно је да би остваривање грчких националних претензија, које се односе на решење албанског питања, захтевање стратешких тачака од Бугарске, и уопште начина организације европског мира, било лакше кроз партнерство Грчке и Југославије, јер се њихови интереси не сукобе ни у једном од горе наведених питања.

Било би пожељно да се на овим основама, кроз споразум Грчке и Југоскавије, створи Балканска Унија. На тај начин би будући чланови уједињења били принуђени да прихвате услове који су постављени од стране влада Грчке и Југославије, а не да уђу према њиховим правилима

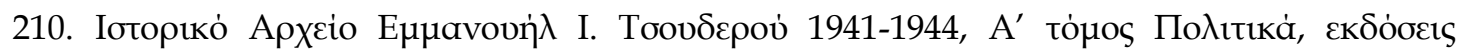
Фитра́кฤ, бо. 471-473. 
или захтевима који би били вођени њиховим интересима. Тако се ствара једна јака унија Атине и Београда око које ће се окупити, под једнаким условима и остале балканске државе које ће се придружити Унији. У случају слабљења сарадње Грчке са Турском, и неостваривање уске сарадње са Југославијом, одвело би Грчку у штетну, па чак и опасну, изолацију.

Након пријема осталих балканских држава у Унију, везе Грчке са Југославијом ће очувати посебну важност. Са тачке гледишта безбедности и реорганизације међународних односа након рата, Грчка ће имати са Југославијом заједничке интересе, јер су обе земље изложене истим опасностима. У свим међународним кризама су били у истом табору, тако да је у интересу Грчке да задржи Југославију у оквиру Балканске Уније211.

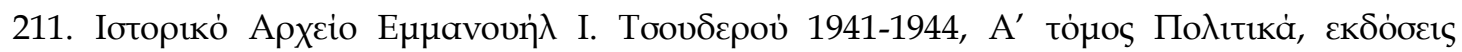

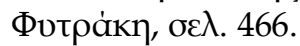




\subsection{2 ГРЧКО-ЈУГОСЛОВЕНСКИ СПОРАЗУМ ОД 15. ЈАНУАРА 1942. ГОДИНЕ}

У периоду избеглиштва у Великој Британији, владе Југославије и Грчке развиле су дипломатске везе које се ограничавају споразумом од 15. јануара 1942. године, с обзиром на то да не постоје други званични документи о сарадњи ове две владе. Споразум је склопљен у Лондону 15. јануара 1942. године, а потписали су га, са југословенске стране председник Министарског савета Слободан Јовановић и Министар спољних послова Момчило Нинчић, који се у британским круговима наводио као главни заговорник склапања споразума, док су са грчке стране то учинили Председник владе Емануил Цудерос и његов заменик, подсекретар Министарства за спољне послове Симопулос212. По мишљењу Форин Офиса, стварањем Балканске уније, где би национални суверенитет био замењен принципом колективног, отклонили би се и решили многи од проблема који су узрок међусобне нетрпељивости балканских народа.

Значај стварања Југословенско-грчке уније истакнут је још на првом састанку Симовића и Черчила. Краљ Петар је у интервјуу за један британски лист поновио принцип да Балкан треба да припада балканским народима, додавши да су Југословени и Грци најбољи представници тог принципа. Нинчић и Симовић су Унији придавали велики значај, сматрајући да ће она обезбедити заједничку акцију двеју земаља на Конференцији мира. Међутим, Грчка влада била је реалистичнија. Премијер Цудерос размишљао је о разним облицима будуће балканске заједнице, али је у исто време актуелизовао граничне проблеме.

Разлике између Грчке и Југословенске владе нарочито су биле присутне у првим нацртима планова о будућој балканској заједници.

212. Ристовић Милан, Политички односи на Балкану 1941-1944 (У светлости извештаја југословенске амбасаде у Анкари), рукопис, Београд, 1981, стр. 63-65. 
Југословени су били за политичко представништво које би сачињавали премијери и министри спољних послова, а Грци су подржавали идеју о представништву на нивоу подсекретара док би се премијери састајали само у посебним приликама. Југословенска влада је предлагала да овај орган врши координацију у области спољне политике, да контролише извршавање одлука, да арбитрира у случају неспоразума. Грци су били само за стварање једне интербалканске комисије и заједничког одбора за штампу 213 .

Југословени су предлагали да заједнички војни орган сачињавају министри рата и начелници генералштаба, чији би задатак био да ради на стварању заједничке федералне армије и на припреми заједничког плана одбране; Грци су сматрали да овај орган треба да чине само начелници оних генералштаба, чији би задатак био само организовање сарадње националних армија.

Југословенска влада је у будућој федерацији замишљала постојање једног економског органа састављеног од по два члана сваке владе, а чији би задатак био координација политика цена, успостављање царинске уније, заједничко економско планирање, устројство саобраћаја и заједнички монетарни систем; Грчка влада је предлагала само заједничке финансијске и економске експерте и заједничку царинску унију.

Југословенски представници су предвиђали заједничке парламентарне делегације које би се окупљале једном или два пута годишње и разматрале питања од општег интереса; Грци су наглашавали да владе треба само да обезбеђују заједничке састанке представнике Уније. Југословени су предлагали стални биро са политичком војном и економском секцијом, који би изучавао сва питања везана за сарадњу земаља чланица, и вршио контролу извршавања заједничких одлука; Грци су овај проблем једноставно занемарили 214 .

213. Веселин Ђуретић, Влада на беспућу, Београд: Институт за савремену историју «Народна књига», 1982, стр. 112-113.

214. Веселин Ђуретић, Влада на беспућу, Београд: Институт за савремену историју «Народна књига», 1982, стр. 113. 
Грчко-југословенски споразум од 15. јануара 1942. године за нормално функционисање Балканског савеза предвиђао је стварање одређених органа који би се редовно састајали, Политички орган, Економско-финансијски орган, Стални војни орган и Стални биро 215.

Задатак Политичког органа био би усклађивање спољне политике држава чланица, тако да се у питањима од међународног значаја води јединствена политика. Надлежност самог органа састоји се у благовременом консултовању када су спољни интереси чланица Уније угрожени. Такође би био одговоран за разна билатерална питања међу чланицама. На крају, под његовим надзором саставиле би се две комисије, једна са циљем допуне споразума о духовној и културној сарадњи као и праћења њихове примене, и друга за синхронизовање органа штампе за заштиту интереса јавног мњења чланица, односно за заштиту интереса обе земље.

Економско-финансијски орган, где би учествовала по два члана из сваке владе задужена за економско-финансијака питања, за циљ би имао усклађивање политике спољне трговине и царинских тарифа да би се склопио царински савез, затим израду општег економског програма, унапређење саобраћаја (железничког, пловидбеног, телеграфског, телефонског итд.), и на крају, радио би на припреми пројекта конвенције која би омогућила успостављање балканске монетарне уније 216.

215. Ристовић Милан, Политички односи на Балкану 1941-1944 (У светлости извештаја југословенске амбасаде у Анкари), рукопис, Београд, 1981, стр. 65.

216. Богдан Кризман, Југословенске владе у избјеглиштву1941-1943(Документи), Загреб: Глобус (Архив Југославије), 1981, стр. 37-38 А.Ү.Е. (Архив Министарства спољних

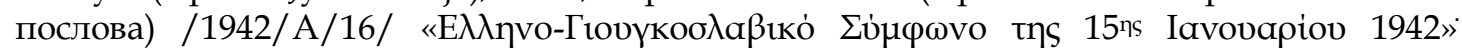
Службене Новине Краљевине Југославије (Ратно издање), бр. 6-1, 30. априла 1942.

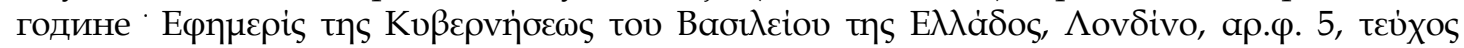
прஸ்tov, 9 Фєßроoарiov 1942 А.Ү.Е. (Архив Министарства спољних послова)

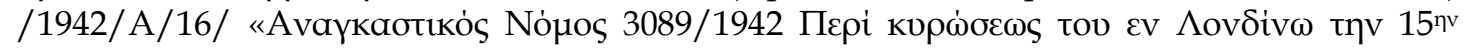

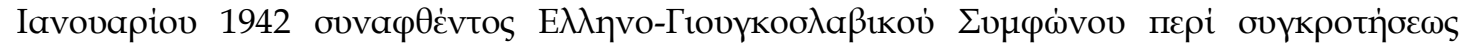

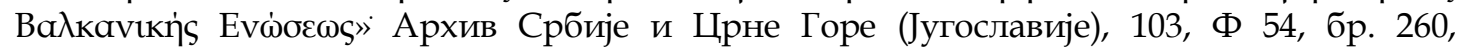
Споразум о Балканској Унији између Краљевине Југославије и Краљевине Грчке Архив Србије и Црне Горе (Југославије), 103, Ф 54, бр. 260, Споразум између Краљевине Југославије и Краљевине Грчке о Установљену Балканске Уније Архив Србије и Црне Горе (Југославије), 103, Ф 54, бр. 260, Agreement between The Kingdom of Yugoslavia and 
Стални војни орган, у коме би владе представљале команданте штабова, функционисао би паралелно са националним штабовима и уједно би представљао Генералштаб оружаних снага. Такође, исти орган обухватао би два бироа, један за војску и ваздухопловство и један за морнарицу. Имао би задатак да усклађује активности које се односе на сарадњу националних оружаних снага чланица Уније, да установи заједнички план одбране и јединствени тип наоружања.

Стални биро, који се такође дели на две секције, политичку и економско-финансијску, решавао би питања од интереса за читаву Унију. Овај орган образовао би секретаријате органа Уније, такође би на себе преузео припрему материјала за радове и проучавања разних питања, чије би решење успоставило ефикаснију политику и економскофинансијску сарадњу чланица. Биро би заседао у случајевима када то захтевају околности. Парламенти двеју држава би тесно сарађивали и представници парламената би се састајали често да би расправљали о темама од општег интереса ${ }^{217}$.

The Kingdom of Greece concerning the Constitution of The Balkan Union Архив Србије и Црне Горе (Југославије), 103, Ф 54, бр. 260, нацерт Грчко-југословенског Споразума 15. јануара 1942. године Ристовић Милан, Политички односи на Балкану 1941-1944 (У светлости извештаја југословенске амбасаде у Анкари), рукопис, Београд, 1981, стр. 66-67 Веселин Ђуретић, Влада на беспућу, Београд: Институт за савремену историју «Народна књига», 1982, стр. 119.

217. Богдан Кризман, Југословенске владе у избјеглиштву1941-1943(Документи), Загреб: Глобус (Архив Југославије), 1981, стр. 37-38 А.Ү.Е. (Архив Министарства спољних

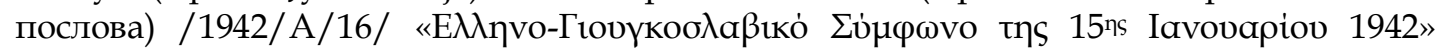
Службене Новине Краљевине Југославије (Ратно издање), бр. 6-1, 30. априла 1942.

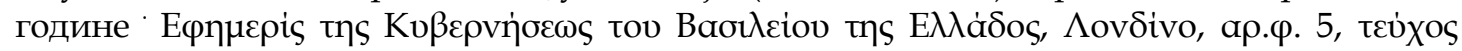
прஸ்тov, 9 Фєßроoарiov 1942 А.Ү.Е. (Архив Министарства спољних послова)

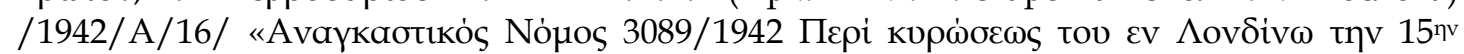

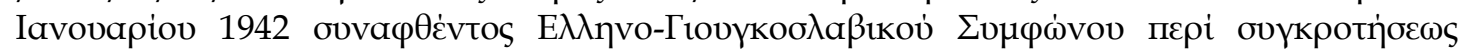

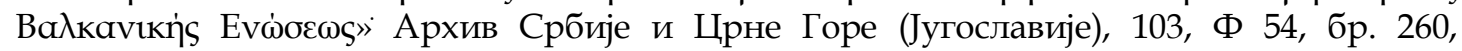
Споразум о Балканској Унији између Краљевине Југославије и Краљевине Грчке Архив Србије и Црне Горе (Југославије), 103, Ф 54, бр. 260, Споразум између Краљевине Југославије и Краљевине Грчке о Установљену Балканске Уније Архив Србије и Црне Горе (Југославије), 103, Ф 54, бр. 260, Agreement between The Kingdom of Yugoslavia and The Kingdom of Greece concerning the Constitution of The Balkan Union Архив Србије и Црне Горе (Југославије), 103, Ф 54, бр. 260, нацерт Грчко-југословенског Споразума 15. јануара 1942. године Ристовић Милан, Политички односи на Балкану 1941-1944 (У светлости извештаја југословенске амбасаде у Анкари), рукопис, Београд, 1981, стр. 66-67 Веселин Ђуретић, Влада на беспућу, Београд: Институт за савремену историју «Народна књига», 1982, стр. 119. 
Нинчић се сусрео са Сарџентом 31. децембра 1941. године и саопштио му да је, без обзира на проблеме, достигнут један задовољавајући ниво договора са Грцима. Додао је такође да је предочио совјетском амбасадору у Југословенској влади Богмолофу нацрте Балканског савеза. Богмолоф је показао пријатељску заинтересованост, што је умирило Југословенску владу која се, уосталом као и Грчка влада, одувек прибојавала совјетских реаговања 218 . Грчка влада је такође саосећала у југословенским страховима. Неколико дана касније, посредством својих амбасада, две владе питале су Форин офис да ли би требало да обавесте САД и Совјетски Савез о потписивању споразума. Сарџент им је саветовао да дају велики публицитет споразуму јер се очекивала повољна реакција САД-а, а неутрална, али не и негативна, Совјетског Савеза 219 .

Две владе затражиле су од британске да их јавно подржи. И заиста, Иден је председавао церемонијом потписивања која је одржана у Форин офису 15. јануара 1942. године. Споразум је предвиђао стварање сталног саветодавног механизма са двема владама на челу, са циљем усклађивања на политичком, војном и економском плану. Потврђено је још и да би се спољна политика ускладила и да би се одмах припремали планови за царинско и монетарно уједињење 220.

Јасно је да, бар у плановима, Грчко-југословенски споразум од 15. јануара 1942. Године имао је више додирних тачака са плановима А. Папанастасиуа него са Балканским савезништвом, које се брзо распало

218. F.O. $371 / 33133$, R 57.

219. А.Ү.Е. (Архив Министарства спољних послова) /1942/A/16/ Royal Greek

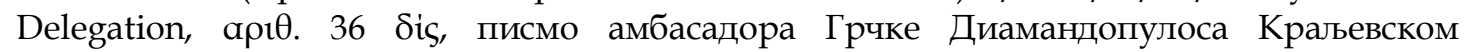
Министарству спољних послова Грчке, Washington, 6. јануара 1942. године Архив Србије и Црне Горе (Југославије), 103, Ф 54, бр. 260, шифрован телеграм Фотића, пов. бр. 10, отправљен из Вашингтона 5. јануара 1942. године у 13.26 часова и примљен у Лондону 6. јануара 1942. године у 10.00 часова Архив Србије и Црне Горе (Југославије), 103, Ф 54, бр. 260, парафраза Фотића, бр. 20, Вашингтон, 6. јануара 1942. године $\Delta \imath \beta \dot{v} \eta$

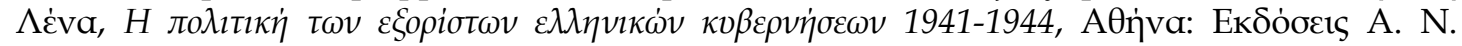
$\Sigma$ ákкоvגa, 1991, об. 241-242.До тада Совјетски Савез није имао ништа против Балканских Споразума. Једноставно је одавала хладном скептичношћу. Касније ће променити став (F.O. 371, R 316/43/67).

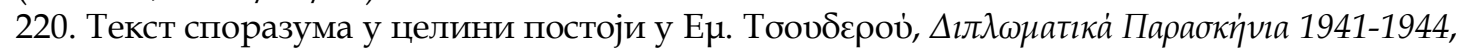
Aөท்val, 1950, стр. 265-268. 
пре Другог светског рата. Тада је једина разлика била да се идеја балканског уједињења заснивала на позитивним начелима и имала је визионарске присталице, док се сада заснивала на одбрамбеним принципима који су служили плановима других. У суштини нико није веровао, нити је имао расположивост да се озбиљно бори за уједињење Балкана 221.

Током церемоније потписивања, млади монарх Југославије Петар, је изјавио: „Имам разлога да се надам да ће се, осим Балканског Савеза, створити и један Централноевропски савез на основу Чешко-пољског споразума. Ова два савеза који почивају на истим принципима и истим идејама, створиће заједно са јединственим вишим органом, једну велику организацију која ће пружати озбиљне гаранције за мир у Европи“222. У складу с тим Краљ Петар се сложио у потпуности са Нинчићем који је веровао у тесну сарадњу ове две групе 223 . Али то не значи да су се сви остали министри избегличке Југословенске владе такође слагали. На пример, Гавриловић је страствено подржавао федерацију Словена (Југословени и Бугари или само Срби и Бугари) 224. У општим цртама можемо рећи да су се Југословени залагали за сарадњу са Чесима и Пољацима, док су се Грци јасно противили овој идеји ${ }^{225}$.

Британско министарство спољних послова на следећи начин је тумачило ову разлику између две владе: „Знамо да Југославија има посебне унутрашње разлоге, које нема Грчка, да достигне идеју источноевропске федерације. На располагању имају само две алтернативне могућности, припајање Русији или учешће у једној већој федерацији, усмереној колико против Русије толико и против Немачке. Бирају другу

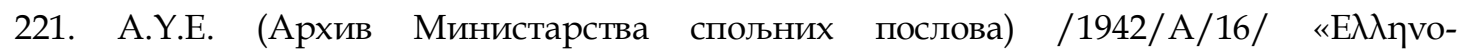

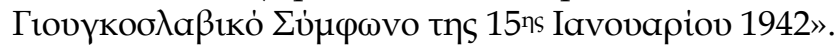

222. F.O. 371, R 504/43/67.

223. Богдан Кризман, Југословенске владе у избјеглиштву1941-1943 (Документи), Загреб: Глобус (Архив Југославије), 1981, стр. 38-39.

224. Бранко Петрановић, Балканска Федеращија 1943-1948, Београд, 1991, стр. 42-43 Marc Wheeler, Britain and the war for Yugoslavia 1940-1943, East European Monographs, Boulder,

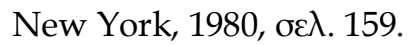

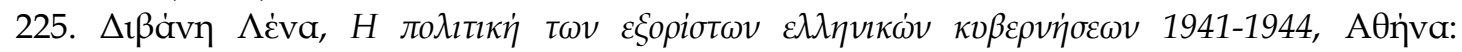

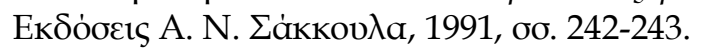


опцију. Грци опет имају своје разлоге да оклевају. Као јединствена држава са снажно развијеним етничким системом и изван опасне зоне руског утицаја, бране свој идентитет више него Југословени и не желе да буду припојени некој федерацији. Њихови најближи суседи, Бугари, јесу и њихови традиционални непријатељи који одбацују идеју да би требало да им пруже руку пријатељства“226.

Надлежни у Форин офису направили су тачну процену. Грци заправо, иако су напредовали у споразуму са Југославијом, нити су бранили визије, нити су били рашчистили кога су желели у чувеном Балканском савезу и под којим условима. Још увек нису желели да изазивају своје измучене земљаке у окупираној Грчкој дајући упечатљиве изјаве о послератном Балкану, док су они на улицама умирали од глади. И коначно, нису без разлога желели да изазову Русе, који још увек нису отворено изрекли своје примедбе, али било је толико очигледно да нису били задовољни развојем догађаја 227.

Из ових разлога Цудерос је уложио протест Форин офису 20. јануара 1942. године у вези са садржајем говора који је одржао Краљ Петар. Иако је Форин офис разумео мотиве грчког премијера, није се слагао са њим. Став Југославије више се слагао са њиховим плановима. Иначе, као што је забележио Роуз 21. јануара 1942. године: „Погрешно је што придајемо пажњу руским негодовањима. Сигурно је да Руси имају своје планове за послератни период и да добро знају да ће им сама моћ у оружју помоћи да постигну своје циљеве. Стаљин је био сувише сумњичав и реалиста да би дозволио да на ток рата утиче било какав хипотетички план избегличких влада за послератну Европу“228.

226. F.O. 371/33133, R 735.

227. Свакако ни Југословени нису желели да изазову Совјетски Савез па су били опрезни. Наравно, када је јануара 1942. генерал Сикорски предложио Нинчићу војно савезништво Пољске и Југославије, Нинчић је одговорио како су војна савезништва провокативна и треба да се избегавају (F.O. 371, R 584/43/67) $\Delta$ ı

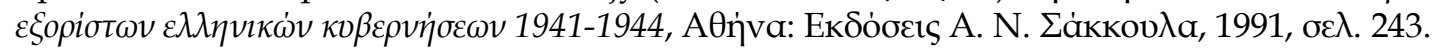

228. У питању је његов коментар на Цудеросово негодовање који је вредан дивљења због његове реалности, која је превазилазила и Стаљина (F.O. 371/33133, R 735). 
И поред свега тога притисак Пољске био је толико велики и антисовјетизам генерала В. Сикорског толико снажан, да је и Југославија почела да оклева. На пролеће 1942. године читава ствар се још више закомпликовала настројеношћу Нинчића да склопи савез са Совјетским Савезом, као и преговорима Идена и Молотова о Енглеско-совјетском Савезу 229 . Неке британске службе веровале су да би склапањем овог уговора могле да притисну Совјете да подрже Балканску Федерацију 230. Ово наравно није било реално, пошто су од пролећа 1942. године Совјети почели отворено да заузимају непријатељски став према Споразуму о балканском уједињењу.

Овде треба нагласити да је Форин офис донекле ипак био у праву када је тврдио да Совјетски Савез још увек није имао јасно негативан став. У ствари, Совјетски Савез је био у стању ишчекивања. Децембра 1941. године Стаљин је у Москви рекао Идену да његова земља неће негодовати ако одређене државе желе да се уједине. Раније, августа 1941. године, Мајски је југословенском амбасадору у Лондону рекао да би балканско уједињење било добро решење Југословенско-бугарских проблема. Став Совјетског Савеза је постао очигледно негативан након победе над Немцима у Москви 231.

И поред неизвесне климе избегличке владе Грчке и Југославије састале су се средином септембра 1942. године у циљу усклађивања њихове спољне политике. Том приликом одлучили су да се консултују пре него што предузму било какве мере у вези са њиховим балканским суседима, да не сарађују са такозваним „слободним покретима“ и да не

229. Југословени су желели да поново ступи на снагу споразум о не-нападању који су априла 1941. године потписали са Совјетским Савезом. Међутим, Совјетски Савез је предложио потписивање једног петогодишњег уговора узајамне помоћи. Форин Офис је био сумњичав у вези са намерама Совјетског Савеза према Југославији.

230. SOE је веровао у ову могућност. Међитим Форин офис је то негодовао (F.O. 371, R 4182/43/67).

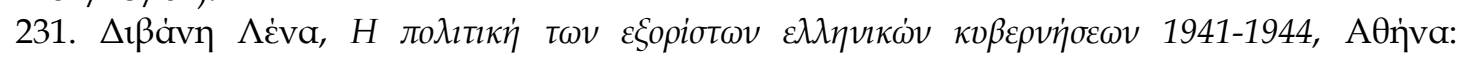

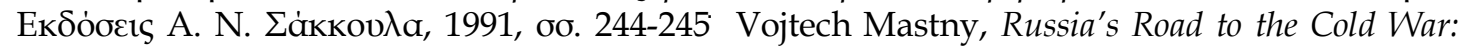
diplomacy, war-fare and the politics of communism 1941-1945, Columbia University Press, 1979, oб. 55-58. 
сарађују са земљама које имају граничне проблеме са Совјетским Савезом (дакле, са Чехословачком и Пољском) 232.

Паралелно, све ово време објављивани су многи радови у вези са Балканским споразумом и могућношћу сарадње са Централноевропским савезом. Кључно неслагање међу ауторима био је став Совјетског Савеза. Једни су веровали да поменути савези треба да функционишу као тампон зона око Совјетског Савеза, а други су, супротно томе, сматрали неопходном совјетску сарадњу за опстанак ових савеза. Није било могуће да Совјетски Савез издржи једну такву зону око себе, што је учинио јаснијим на састанку у Москви, октобра 1943. године ${ }^{233}$. Веровала је да су избегличке владе биле веома нестабилне и без кредибилитета 234 да склапају такве обавезујуће споразуме тако рано 235 .

Самим тим што је Совјетски Савез деловао против њега, крајем 1942. године. Балкански споразум био је већ „једном ногом у гробу“. Негативно су утицали и унутрашњи проблеми и кризе избегличких влада Грчке и Југославије. Из Форин офиса су се, као и оба премијера, стално позивали на споразум од 15. јануара 1942. Године, али су у суштини сви знали да је то било „мртво слово на папиру“. Британци су већ радили на новим решењима за Балкан разговарајући директно са Русима 236.

232. F.O. $371 / 33134$, R 6626.

233. Према званичној совјетској историји Стаљин је рекао: «САД и Енглези се тајно ослањају на старање федерација малих држава Централне и Југоисточне Европе, које ће бити искоришћене у циљу ширења британског и америчког империјализма. Совјетски Савез не може да се сложи са овим плановима» (B. Ponomaryov, A. Gromyko, V.

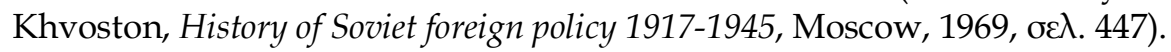

234. Међутим, поред свега, Совјетски Савез се није мешао у проблеме међу балканским земљама и одржала је контакт са званичним владама Југославије и Грчке.

235. Осим тога Совјетски Савез није се мешао у разлике балканских држава и одржао је контакт са званичним владама Југославије и Грчке.

236. Сарџент је у јануару 1943. године прорачунао њихову снагу наоружања против совјетског ширења у области: „Могућност да се на крају рата војске САД-а и Енглеске налазе на Балкану, да Турска буде могућа савезничка држава такође с војском на Балкану и чињеница да ћемо ми и Американци да контролишемо организацију реконструкције који ће предузети да снабде намирницама изгладнелу популацију Балкана за један неодређени период након повлачења Сила Осовине“. Нигде се не наводи Балкански Споразум (Документ се налази у Marc Wheeler, Britain and the war for

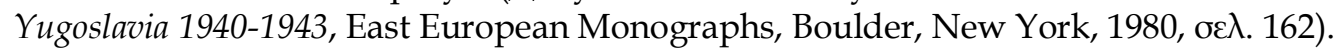


Тако је утихнуо и Централноевропски споразум. Чехословачка је, 12. децембра 1943. Године, потписала уговор пријатељства и послератне сарадње са Совјетима, што је пољуљало њене добре односе са Пољском и заувек онемогућило њихове заједничке планове 237.

237. $\Delta$ «

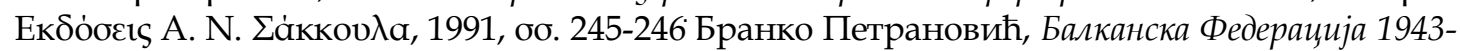
1948, Београд, 1991, стр. 40 F.O. 371/31109. У целом досијеу се описују пољске сумње о улози Чехословака. Форин офис их смирује и готово их моли да не изазивају толико отворено руско непријатељство. 


\subsection{3 ПРОЦЕНЕ ГРЧКЕ ВЛАДЕ У ВЕЗИ \\ СА ПОТПИСИВАњЕМ \\ ГРЧКО-ЈУГОСЛОВЕНСКОГ СПОРАЗУМА}

У Балканској унији Југославије и Грчке Велика Британија је видела одбрану својих геополитичких, војностратегијских и економскополитичких интереса у залеђу источног Средоземља и Дарданела, кључа Блиског Истока. Пре свега треба да разјаснимо да британски план није обухватао само балканско уједињење. У Форин офису се говорило о „конфедерацијама држава које се налазе између Немачке 238 и Италије с једне, и између Русије и Турске с друге стране“. Обухватао је дакле, две групе, централноевропску и балканску, које би међусобно тесно сарађивале стварајући један зид према немачком и совјетском империјализму. Наравно, надлежни у Британији схватили су да би се будућност и делотворност ових савеза нашле у непосредној међузависности са војном равнотежом сила у тренутку ослобођења. У том тренутку, међутим, није постојало друго решење239.

Септембра 1941. године охрабривали су Југославију и Грчку да отпочну разговоре. Већ су били почели разговори избегличких влада Пољске и Чехословачке, који су окончани споразумом 3. децембра 1941. године. Језгро будуће конфедерације Централне Европе биле би ове две државе, а очекивано је и прикључивање Аустрије, Мађарске и Румуније ${ }^{240}$. У складу са изјавама чехословачког Премијера Бенеша: „Ово уједињење ће решити проблеме као што су незапосленост и помоћи ће у развоју неразвијених привредних области. Такође је веровао да само кроз такву врсту друштвених промена би било могуће да се избегну насилне побуне и комунизам. Свакако, наговестио је Бенес, страх од комунизма

238. Званично, претња за ове државе је углавном била Немачка, под британском сагласношћу. Међтим, у суштини су се бојали совјетског ширења иако то нису јавно износили као не би изазвали великог савезника.

239. Бранко Петрановић, Исторуја Југославије 1918-1988 (друга књига), Београд: Нолит, 1988, стр. 20.

240. Бранко Петрановић, Балканска Федерација 1943-1948, Београд, 1991, стр. 37-38. 
не треба да нас удаљава од Совјетског Савеза. Треба да одржавамо исто одстојање међу супер-силама“241.

Насупрот томе, прогнани Пољаци су више учествовали у овом споразуму надајући се стварању једног cordon sanitaire око Совјетског савеза и није их занимало то да ли ће овај подухват изазвати, или не, совјетско неповерење. Ово је вероватно била једна нормална реакција са њихове стране, с чињеницом да су успоставили дипломатске односе са Совјетским Савезом тек 30. јула 1941. године, под притиском Енглеза. И наравно, ово поновно зближавање им није помогло да забораве совјетску експанзију на њихову штету. Насупрот томе почели су да верују у то да су Британци били спремни да их „издају“ с циљем да не покваре хармоничне односе са Стаљином 242 .

Међутим, вратимо се на Грчко-југословенски споразум који је почео да се разматра у јесен 1941. године. У Форин офису су били свесни тешкоћа које би произашле из примене овог уговора, поготово због традиционалне балканске склоности размирицама. Карактеристичан пример био је захтев који је Цудерос поднео Форин офису, новембра 1941. године, у коме се говорило о преправкама грчко-југословенских граница, у корист Грчке, баш у тренутку планирања уједињеног Балкана 243 . Подсетићемо у овом делу на разлике које су раздирале

241. Vera Dean, «European Agreements for post-war reconstruction», oto Foreign policy reports, 18, 1942-43, бо. 1-12.

242. Пољаци су имали права да верују у то. Карактеристично је то да су сви, Енглези и Совјети, наводили територијалне претензије Совјетског Савеза као линију Curzon, тојест граничну линију коју је био предлагао лорд Curzon 1920. године како би раздвојио пољску и руску војску. У стварности је међутим Стаљин то подразумевао, и сви су то знали, граничну линију Рибедроф - Молотоф, која се значајно разликовала од граничне линије Curzon-a. Када су Пољаци били приморани 30. јула 1940. године да потпишу Пољско-совјетски споразум, у страху су видели мноштво двосмислених ставки у вези са границом, чињеница која је водила ка оставкама три министра. О незавидном положају пољске избегличке владе види детаљно J. Coutouvidis, J. Reynolds, Poland 19391947, Leicester University Press, 1986 Antony Polonsky, The Great Powers and the Polish Question, 1941-1945, L.S.E., 1976 G. Kacewicz, Great Britain, The Soviet Union and the Polish Government in Exile, Martinus Nijhoff Publishers, 1979.

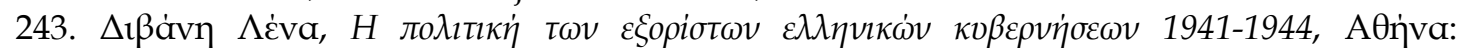

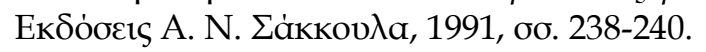


триетничку Југославију, а нарочито на српско-хрватске чарке 244 , које су утицале и на преговоре о Балканском споразуму.

Двадесетог новембра 1941. године М. Нинчић се пожалио О. Саргенту да Грци у ствари нису желели стварно уједињење већ савезништво, у тренутку, наравно, када се исти плашио да су Хрвати углавном под утицајем Пансловенског покрета и нису подржавали поменути споразум зато што би то заправо разбеснело Совјетски Савез ${ }^{245}$. Један други проблем, који произилази из преговора, била је Албанија. Грци су желели да у будућности учествује у Балканском Савезу, али тек пошто би јој одузели Северни Епир. Југославија је изјавила да ће, ако Грци узму Северни Епир, онда и она тражити Скадар и друге области које су настањивали Југословени. Али, у овом случају, не би више постојала независна, одржива албанска држава. Са друге стране, бивши Краљ Албаније који је тада избегао у Лондон, Ахмет Зогу, веровао

244. Проблеми југословенске избегличке владе, као и грчке, били су многи. У њеним круговима није постојао ни политички консензус, ни узајамно поверење да би се решили њени проблеми. Постојала је шира партијска прихваћеност у влади али њена уставна законитост заснивала се само на краљу због одсуства изабраног парламента (као што је био случај и у грчкој избегличкој влади, само што југословенска влада није имала велику партијску прихваћеност). Као и грчки и југословенски политичари годинама нису имали власт, а када су је преузели, одједном су изгледали потпуно дезорјентисани у простору и времену. Нису осећали да би овај рат могао да промени све. Били су традиционално монархисти, али чари краљевине избледеле су деспотским међуратним експериментисањима, баш као и у Грчкој. Веровали су, иако су их се и плашили, да ће им Енглези решити проблеме; а на крају су их Енглези држали у мраку у вези са плановима за Југославију. Управо као и Грци, били су збуњени разним антфашистичким центрима власти у Британији и нису поседовали своја средства комуникације са својом земљом, али су се они, за разлику од Грка, за њих жустро залагали (Бранко Петрановић, Историја Југославије 1918-1988 (друга књига), Београд:

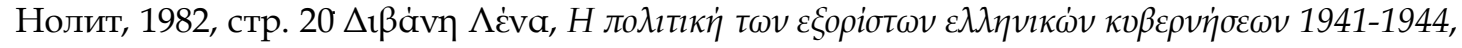

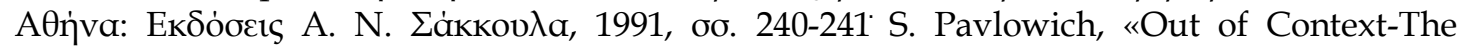
Yugoslav government in London 1941-1945», Journal of Contemporary History, London, Vol. 16, 1981, бо. 89-118). Суштинска разлика југословенске са грчком избегличком владом је била то што су у случају Југославије значајнији били партизани, док су у случају Грчке били више витну избегличка влада и Краљ. То је због тога што се грчки герилци никада нису сматрали неопходним стратешким снагама од стране Черчила, насупрот Титовим партизанима. Због Тита их није занимала избегличка југословенска влада и услови њеног повратка, чинећи изузетак само у случају младог краљ Петра. Због њега су притискали Тита да нађе један начин да преговара са њим због британске помоћи коју је Тито узимао. Више детаљ у вези са развојем догађаја у окупираној Југославији, о избегличкој влади и о односима обе са Британциам, види Jozo Tomasevic, War and revolution in Yugoslavia 1941-1945, the Chetniks, Stanford University Press, California, 1975.

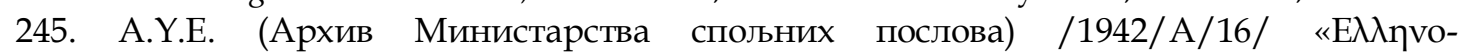

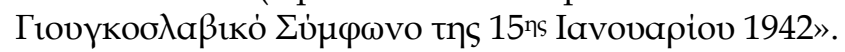


je у учешће његове земље у Балканском споразуму, али нико му није придавао значаја пошто није имао никакву званичну функцију 246.

Грчка страна је, већ од самог почетка преговора о потписивању Грчко-југословенског споразума, и поред тога што је на крају потписала, југословенски предлог прихватила са резервом. Грчка влада је сматрала да би један такав споразум користио Југословенима с обзиром да је Југославија била на последњем месту у хијерархији савезничких земаља. Јаз који раздваја Србе и Хрвате, док се грађански рат непрестано шири, представља неизбежну чињеницу. Такође, влада генерала Симовића, будући да је најмање допринела савезничкој борби, и да није имала војску али ни могућност да је окупи, будући свесна немоћи у којој се налази, колико због политичких толико и због психолошких разлога, тежила је склапању споразума са Грчком.

Потписивањем Грчко-југословенског споразума Грчка би признала територијални режим и границе Југославије одређене пре немачког напада. Истовремено, грчко вођење политике на Балкану било би ограничено обавезом да Грчка влада обавештава Нинчића о свакој својој активности, што би представљало велики дипломатски успех за Симовићеву владу. Њен успех на психолошком плану био би још већи, с обзиром да у Грчкој нема националних и верских мањина, да располаже знатним војним и морнаричким снагама, са дијаспором која представља битан фактор. Тако би Југословенска влада стекла већу превласт на међународном плану, али најбитније је да би један такав споразум утицао и на унутрашњост земље. Хрвати би на заједницу са Србима гледали позитивно и у великом степену би јачала идеја о оживљавању југословенске државе у њеном старом облику. Коначно, генерал

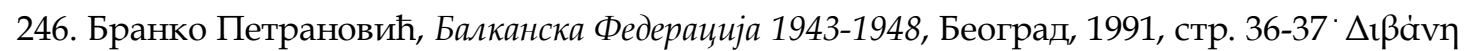

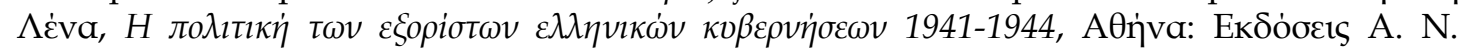

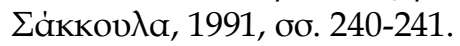


Симовић би у односу на генерала Нинчића и црногорске аутономисте заузео бољи статус у Србији ${ }^{247}$.

Добици које би Споразум обезбедио Грчкој, према проценама Грчке владе, нису били у складу са оном што би добила Југославија. Конкретније, што се политике тиче, Југославија није имала шта да понуди Грчкој. Питање померања северних граница Западне Македоније у корист Грчке било је још теже, пошто је потписивањем споразума признат претходни територијални режим Југославије. Споразум би се примењивао у условима у којима Грчка влада ни на који начин не би могла да предвиди исход.

Грчка влада је још веровала и да Грчка не би требало да се у овом тренутку обавеже да непромишљено потпише некакав споразум којим би постала члан неке коалиције, већ да касније, након што добро размисли, према својим интересима одабере којој би коалицији требало да припада. Такође, Грчка се бојала да би учешће у једној таквој коалицији отежало учвршћивање њених веза са Британијом, које је било циљ њене спољне политике. Реакција грчког народа представљала је још један фактор који је требало узети у обзир. Спољна политика земље престала би да буде независна, пошто је требало да иде у корак заједно са југословенском. Интереси Грчке никада нису долазили у сукоб са српским интересима, међутим оснивање велике југословенске државе вероватно би представљало претњу грчким интересима у овој области ${ }^{248}$.

Анлизирајући Грчко-југословенски споразум од 15. јануара 1942. године, закључујемо следеће: споразум тежи обезбеђивању мира на

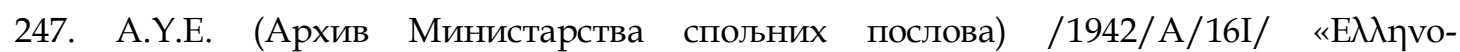

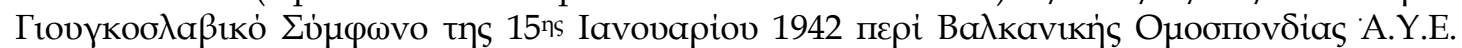

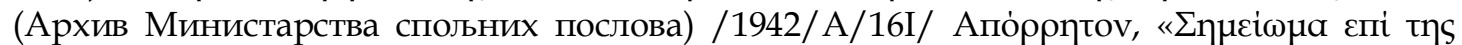

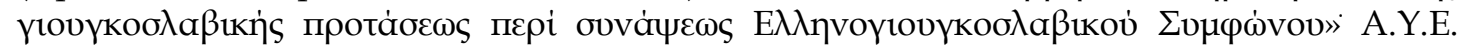
(Архив Министарства спољних послова) /1942/A/16I/ Confidential «Memorandum», Washington, D. C, January 6, 1942.

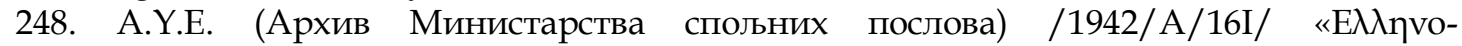

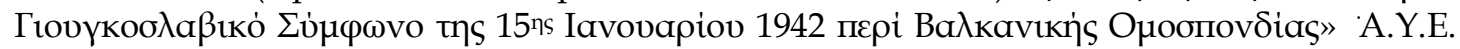

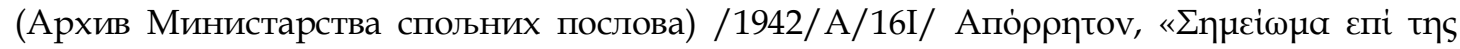

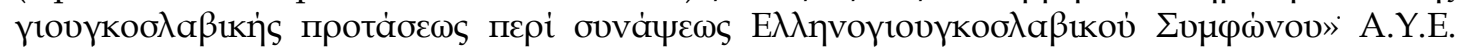
(Архив Министарства спољних послова) /1942/A/16I/ Confidential «Memorandum», Washington, D. C, January 6, 1942. 
Балкану, независности земаља у региону и удаљавање супротстављених утицаја Великих сила, држећи се принципа „Балкан балканским народима“. Политичка сарадња испољава се усклађивањем спољне политике, на начин који открива јединство држава чланица, као што се такође оснива систем судова и мирног разрешења билатералних разлика. Овим споразумом уводи се војна сарадња која за циљ има одбрану европских граница Уније. Предвиђа се ближа економска и културна сарадња оснивањем одговарајућих механизама. На крају, споразум је отворен и за друге балканске државе 249.

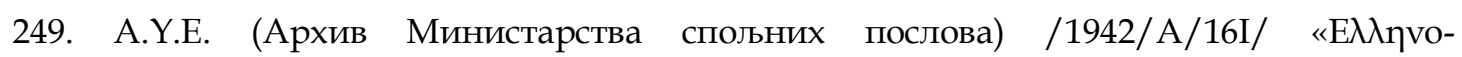

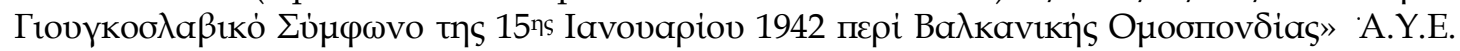

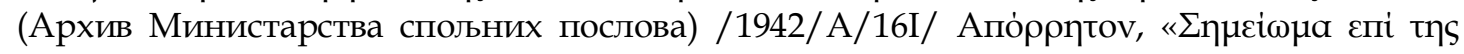

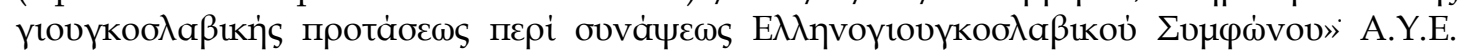
(Архив Министарства спољних послова) /1942/A/16I/ Confidential «Memorandum», Washington, D. C, January 6, 1942. 


\section{З.3 ГРЧКО-БУГАРСКИ ОДНОСИ}

\subsection{1 ПОЛИТИКА ГРЧКЕ ЕМИГРАНТСКЕ ВЛАДЕ ПРЕМА БУГАРСКОЈ}

Бугарска је већ од међуратног периода представљала претњу како за Грчку, тако и за Балкан. Потврђујући сумње међународног јавног мњења, Бугарска је узела учешће у Другом светском рату на страни Сила Осовине. У пролеће 1941. године бугарска војска је окупирала Западну Тракију, Источну као и делове Западне Македоније, Тасос и Самотраки. Ове области је Бугарска преузела на управу као окупатор. У складу са британским извештајима, до јесени 1941. године на хиљаде Грка је било убијено, можда чак и 35.000250. Око 60.000 Грка је пребачено у Бугарску, док је њих 70-80.000 отишло према југу да избегну најсуровију окупацију која се икада десила у тим поднебљима. С друге стране, из Бугарске је дошло око 200.000 људи да се настане на грчку територију251.

Почетком 1941. године Хитлер и Рибентроп су обећали Бугарској да ће јој остварити дуговековни сан - излаз на Егејско море 252 . То је био разлог да Бугарска пожури да сматра ове окупиране области као бугарску територију, чак и без формалног признавања од стране Немачке. Краљ Борис је јавно рекао у свом говору који је одржао у септембру 1941. године: „Захваљујући овој сарадњи (са Немцима и Италијанима) Македонија и Тракија, области које су биле толико лојалне Бугарској, које су јој бесправно одузете и због којих је Бугарска била

250. F.O. 371/37227, R 1399, извештај од 20. јуна 1941. године са насловом „Територијална питања између Буграске и Грчке“.

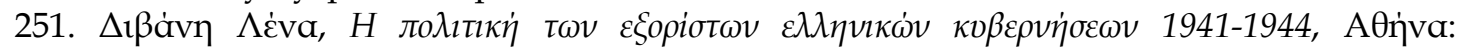

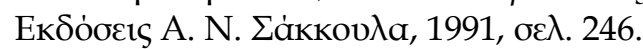

252. Слична обећања су давали и Југославији када је потписала трочлани споразум:

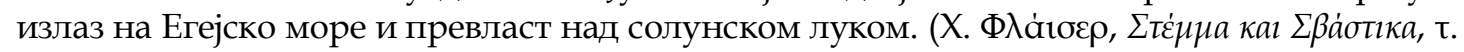

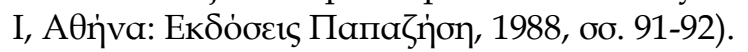


принуђена да се небројено пута жртвује пуне три генерације, сада су враћене у загрљај бугарској родној земљи“253.

Дакле, имајући као циљ да припоји Бугарској области Грчке које су окупирали, а да нису званично објавили рат 254 , декретом од 11. јуна 1942. године покушали су да правно уреде националност становништва на следећи начин: Грци и Југословени бугарског порекла би аутоматски добијали бугарско држављанство. Грци и Југословени српског, грчког и турског порекла су били дужни да изаберу држављанство које желе до 1. априла 1943. године. У случају да не изаберу бугарско морали би да напусте те области. Бугарска је више била забринута за грчки део Македоније, него за југословенски, зато што је становништво у тој области било невољно да прихвати бугарски утицај 255 . Примена овог декрета је суспендована на неодређено време након интервенције немачких власти, јер би велики талас избеглица, као неизбежна последица овог решења, били немогуће прехранити и политичке импликације за Грчку би биле огромне и непредвидиве ${ }^{256}$. Тако је Грчка у последњем тренутку избегла последище оваквог деловања који је покушала да створи Бугарска.

Међутим, бугарски покушаји „бугаризације“ ових територија нису се завршили на овоме. Насупрот томе, окупационе власти су покушале да промене национални карактер тих области затварајући грчке школе, забрањујући грчки језик, мењајући називе улица,

253. Потпуни текст се налази у Е. Kofos, Nationalism and Communism in Macedonia, Thessaloniki, 1964, oع $\lambda .100$.

254. Грчка влада је прије тога обавестила Британце о намерама бугарске владе да промени етнолошки састав у одбласти између Стримона и Нестоса (А.Ү.Е. (Архив

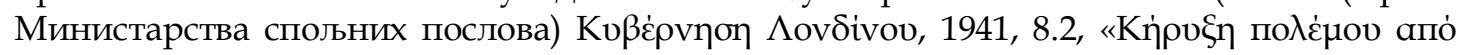

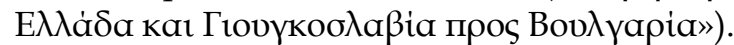

255. Архив Србије и Црне Горе (Југославије), 411, Ф 6, бр. 15, Генерални Конзулат К.J. у Цариграду, Бугарска 1942 и 103, Ф 55, бр. 262, Емигрантска Влада К.J. 1941-1945, Бугарска 1942.

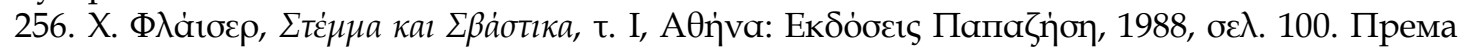
тврдњама аутора, за овај позитиван гест Грчка треба да буде захвална Алденбургу, хемачком амбасадору у Атини. Постоји такође и мишљење да су Немци искористили питање граница да би имали под контролом Бугарску, Италију и Грчку. (HoansJoachim Hoppe, "Germany, Bulgaria, Greece: Their relations and Bulgarian policy in occupied Greece», Journal of the Hellenic Diaspora, Fall 1984, Vol IX, No 3, oo. 41-54). 
уништавајући споменике, затварајући цркве, повећавајући порезе за Грке, приводећи их и хапсећи их. С друге стране, свуда су поставили бугарске команданте, основали су бугарске школе и довели су бугарске свештенике257. Толико је био трагичан положај Грка у бугарској окупационој зони да су сарадници владе из Атине, уз сагласност избегличке владе, у тренутку очаја размишљали да припреме план масовне евакуације грчког становништва из региона 258.

Мере које је предузела Бугарска влада за преображај националног карактера региона и њиховог преображавања у бугарски елемент, приказују се у низу извештаја америчког генералног конзула у Цариграду од 27. октобра па све до краја децембра. У њима се наводи да, и поред мера које је предузела Бугарска влада ради јачања бугарске колонизације у окупираним областима Грчке и Србије, овај њен покушај не доноси очекиване резултате. Генерални конзул детаљно износи недавно предузете мере које су се односиле на јачање финансија бугарских учитеља, који одлазе да подучавају на окупираним територијама на најмање две године. Наглашава чињеницу да је од 1941. године Бугарска влада, путем покоља, насилних масовних евакуација и тероризма, успела да опустоши ове области од њеног становништва и зато Бугари немају озбиљне проблеме што се тиче пребивалишта и уопште настањивања. Међутим, и поред овога, број људи спремних да добровољно емигрирају је био веома мали, с крајњим исходом да се бугарска популација у поменутим областима састоји углавном од окупационих трупа. Генерални конзул не изоставља чињеницу да је у Тракији бугарско становништво представља мањину, додајући да је у

257. Идентичну политику су примењивали на југословенском делу Македоније. Према тврдњама Палмера и Кинга, није постојала никаква приврженост идеји о аутономији, чињеница која није задовољавала оне које су је традиционално подржавали (S. PalmerR. King, Yugoslav Communism and the Macedonian question, Archon books, USA, 1971, oo. 6465). Детаљније о понашању Бугара у грчким областима види чланак Н-J. Норе,

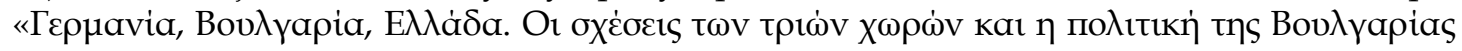

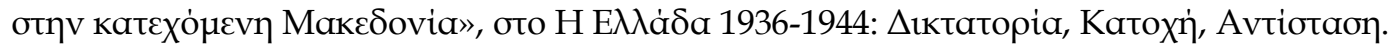

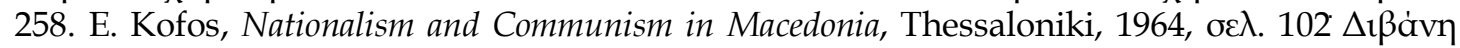

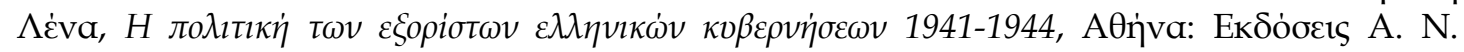

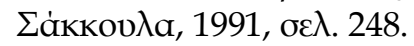


Софији јавна тајна да је колонизација у окупираним областима у опасности. Два су главна разлога за тако нешто: с једне стране присутна је невољност Бугара да се настане на непријатељске територије, а с друге стране постоји недостатак расположивог капитала за систематично настањивање под привлачним условима. Насупрот томе, створена је озбиљна емиграциона струја из окупираних области од стране бугарског становништва, који се боји да ће после победе Савезника бити жртва евентуалне одмазде. Велики дио становништва, пореклом угавном из српске Македоније где постоји значајна бугарска мањина, је до тада отишло у Софију (негде се чак спомиње и бројка од 600.000 људи). Бугарска влада је уложила велике напоре да се заустави ова имиграциона струја, која осим проблема пребивалишта и прехрањивања имиграната, има негативан утицај на морал бугарског народа259.

Прва ствар коју је урадила грчка избегличка Влада према Бугарској у вези са Македонским питањем је била да званично објави рат Бугарској 11. јуна 1941. године. У наставку је узалудно тражила од Британске владе да и она објави рат Бугарској. Енглеска је сматрала да један такав потез не би имао практично значење, док би насупрот томе могао да изазове незадовољство Русије. Цудерос је записао у свом дневнику: „Тражили смо од Енглеске да објави рат Бугарској... То се није догодило, али сазнајем за парадокс да нису били задовољни када је извршен напад на Бугарску због злочина почињених у Грчкој... Критеријуми су потпуно различити... Моћни и немоћни, мали и велики. “260. Грчки премијер је био у праву да се осећа малим и немоћним, јер ни други велики савезник, Совјетски Савез, није званично објавио рат против традиционалних русофила Бугара, припремајући на известан начин терен за један бугарски заокрет према савезницима. У својим белешкама из 4. јула 1941. године појашњава: „У вези бугарских

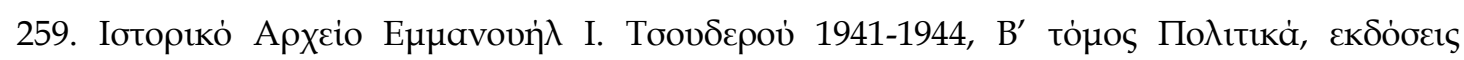
Фитра́кฤ, об. 577-578.

260. Дневник Цудероса у библиотеци Генадиос, датум написаног 3. новембар 1941. године. На крају је Бугарска прогалсила рат Енглеској у децембру 1941. . 
граница нема расправе - имамо право да добијемо ове претензије наспрам Бугара, као паразита немачке војске, и њихових оружаних акција против нас. За време Конференције мира после Првог Светског рата гранична линија на коју је претендовала Грчка је била мало северније од данашње и можда би требало да се вратимо на њу. Што се Бугарске тиче, не бих се сложио са онима који желе њен нестанак“261. У наставку текста препоручује да се предузму мере за сузбијање бугарског агресорског менталитета после рата. Ово што је подразумевао Цудерос, у складу са тумачењем Форин Офиса, било је да је циљ Бугарске владавина на Балкану, и да је једини начин да је контролишу њени суседи је да постану моћнији од ње262. Нажалост за грчку избегличку владу, британски надлежни органи нису делили мишљење са њима. Насупрот томе, налазили су основаним захтев Бугарске за Егеј263, иако то нису изјавили званично пошто су се обавезали да ће бранити интегритет Грчке. Исто се дешавало и са Совјетским Савезом 264.

Исто тако нејасан је био став Британске владе по питању стварања аутономне државе Македоније, план који је веома плашио Цудероса, било да садржи грчки део Македоније или не265. У јуну 1941. године потпредседник Југословенске владе Јовановић је обавестио Цудероса да су га Енглези посаветовали да о Македонији говоре што је мање могуће,

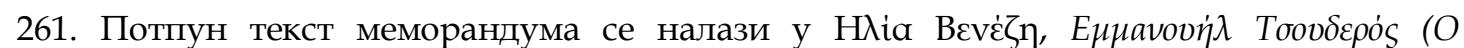

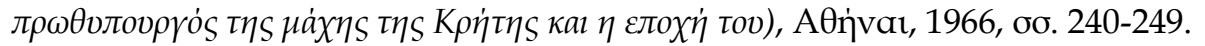

262. F.O. 371/37227, R 1399.

263. F.O. $371 / 37227, \mathrm{R} 1399$.

264. На састанку Иден-Стаљин, децембра 1941. године, Стаљин је нагласио да Бугарска треба да буе кажњена тако што ће предати турској неке територије јужно од Бургаса. Није споменуо ништа и вези изласка на Егејско море, али Британци су мислили све до краја рата да тако нешто има у својим плановима. Напомињемо да је у новембру 1940. године, када је Совјетски Савез покушао да предухитри стварање сарадње Бугарске са Осовином, понудио јој је излаз на Егејско море. Овај податак је из британских извора.

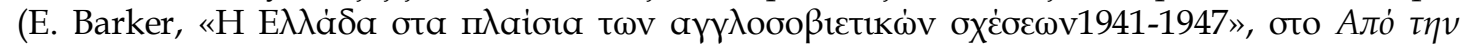

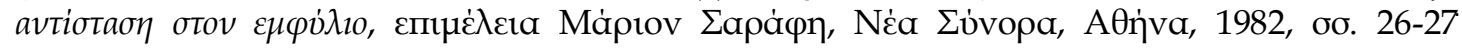

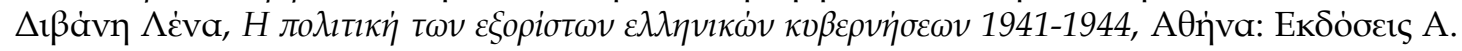

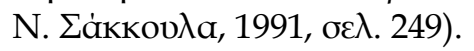

265. У првом случају би, према његовим речима, преполовио Грчку на пола и тако отворио апетит Бугарској. У другом случају би био нарушен мир на Балкану, јер би Грчка постала семе раздора суседних народа. У сваком случају би потпалио мржњу и непријатељства међу балканским народима. 
тј. да сваки пут када се разговара о тој теми да Југословени не износе негодовање у вези са њеном аутономијом. Амбасадор Грчке у Лондону је тражио објашњења и добио је уверење да је Велика Британија противна свакој промени граница на штету Грчке, као и подршку за стварање Балканске заједнице с могућношћу учешћа Бугарске после рата266. Британске службе су покушале да искористе потписивање грчкојугословенског споразума као неку врсте пропаганде. Њихов циљ је био да дестабилизују Борисов режим и да подстакну отпор. Тако су одлучили да почетком 1942. године, поставе следећу недоумицу код бугарског народа: „Балкан за балканске народе, тј. учешће у Балканском споразуму демократских земаља, или константну понижавајућу зависност од Немачке са мамцем Велике Бугарске“267.

У том периоду, К. Тодоров, Г. Димитров и Д. Мацанкијев су послали поруку у име „Слободних Бугара“ властима Грчке и Југославије у вези са недавно потписаним споразумом. У свом писму наглашавају да је то један веома значајан корак за Балканско уједињење, што представља и циљ њихове организације и да цене чињеницу да споразум оставља отворена врата за будући улазак Бугарске 268 . Међутим, избегличке владе Грчке и Југославије, као и Енглези, нису признавале званични статус ниједног од тзв. „слободних покрета“ земаља наклоњених Силама Осовине. Разлог због кога су држали дистанцу од ових покрета отпора је био страх да се можда на овај начин на крају не да помиловање за злочине оних су на страни непријатеља под паролом „народ се одупире изборима његове фашистичке владе“, дакле не треба да буду кажњени. Овај страх је остао за све време окупације и с времена на време је растао

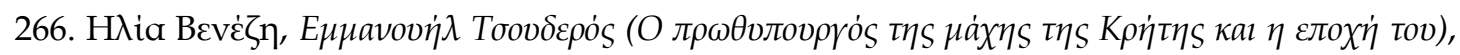

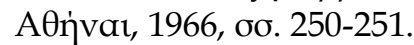

267. F.O. $371 / 33133$, R 934.

268. F.O. 371/33124, R 755, R 986. Димитров је био вођа „Слободних Бугара“ и секретар партије Националне Сељачке Уније Бугарске. Манифестом објављеном 1. марта 1941. Године, као и писмима Рузвелту, Стаљину, Черчилу, Бенесу, Цудеросу, Сикорском и Симовићу, прогласио је незаконитим све радње које предузео краљ Борис и његова власт, јер је то урађено иза леђа народа. Британци су подржавали „Слободне Бугаре“, али нису признавали њиховом вођи никакву званичну функцију. Исти став имали су и премијери Грчке и Југославије, сваки из својих разлога. 
узрокујући кризе у односима међу избегличким владама, које су веровале да су се њихови интереси игнорисани, и Британцима, који су без емоција понижавали своје савезнике како би остварили своје циљеве што ефикасније. Типичан пример представља начин на који су Британци решили питање независности Албаније.

Постојало је једно велико питање који је повезивало три балканске владе, а то је Македонија. Да ли би после рата била формирана једна независна држава, која би се састојала од бугарског, југословенског и грчког дела? Да ли би остао изван грчки део, како би ушла као словенска Македонија у једну будућу федерацији Балкана? Или би проблем остао нерешен? Свака страна је имала многобројна решења о којима се расправљало. Британци су знали да би динамика ратних операција на Балкану мењала осетљиву равнотежу региона и на тај начин би био бескористан сваки план који би евентуално усвојили. Дакле, чекали су развој догађаја, истражујући различите потенцијалне могућности и држећи сва врата отворена 269.

Ни избегличке власти нису могле, са своје стране, да учине много, осим да упозоравају Форин офис да неће толерисати непромишњена решења с њихове стране. Грчка влада је више пута нагласила надлежним Британским службама да, ни у ком случају, неће уступити Бугарској излаз на Егејско море и да неће прихватити, ни на који начин, да се образује аутономна Македонска држава на њену штету. Насупрот томе, захтевала је исправке на граници са Бугарском и кажњавање криваца за бруталности које су починили над грчким становништвом. Форин офис је обично саслушавао грчке захтеве и није се изјашњавао. Међутим, није на њих гледао с разумевањем. Карактеристична је Клутонова забелешка од 21. августа 1944. године: „Грци су узбуђени перспективом територијалних освајања на крају рата... Грчка је узела све на што је имала право од Бугарске на крају прошлог рата и накнадне претензије је

269. У вези овог види студију релевантне Службе за проучавање Форин Офиса о

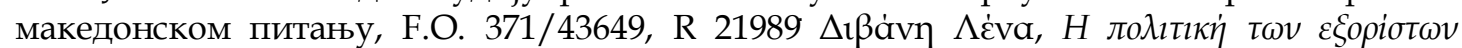

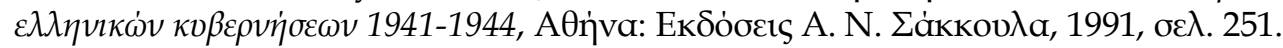


воде само у проблеме у Македонији са Југословенима који су подржани од стране Руса... Наш циљ је дакле да ограничимо захтеве Грка“270.

Македонско питање је било једно од највећих проблема левичарских покрета отпора Балкана за време трајања рата. Политика комунистичке партије Југославије је била да призна Македонију као посебну словенску нацију која ће се придружити својим братским народима у југословенској федерацији. Разлог овоме је био тај што је на неки начин требала да се умањи бугарска свест већине Македонаца из области Вардара, а затим да се успостави југословенска владавина у целој Македонији, као делу југословенске савезне државе 271 . За решење Македонског питања, други по хијерархији после Тита, Светозар Вукмановић-Темпо је предложио братским партијама из региона стварање заједничког балканског штаба. Такође је дао идеју о стварању тајних оружаних снага са мисијом да обилазе пограничне области припремајући људе по националном питању, што је било опасно за Грчку јер би очигледно пропагирало становништву јужнословенског порекла грчке Македоније, идеју о интеграцији Македоније.

Идеја о заједничком балканском штабу, иако се у почетку разговарало о томе, одбачена је од стране грчке комунистичке партије и од НОП-ЕЛАС-а. Грчки комунисти су држали веома опрезан став према југословенским иницијативама које су се, на директан или индиректан начин, односиле на Македонско питање. Комунистичка партија, која је називана „непатриотском“ још од периода када је пропагирала јединствену и независну Македонију и Тракију, пуно пута се нашла у тешком положају због ове теме. Када је покушала да образује герилске групе у Македонији, била је суочена са фанатичним национализмом германофилског ПАО, коју је покушала да неутрализује. Након тога су

270. F.O. 371/43610, R 12903.

271. За детаљну анализу политике југословенских комуниста о Македонском питању види S. Palmer-R. King, Yugoslav Communism and the Macedonian question, Archon books,

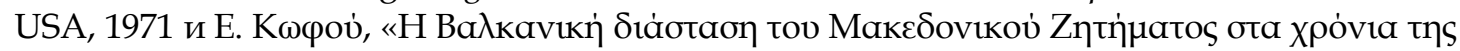

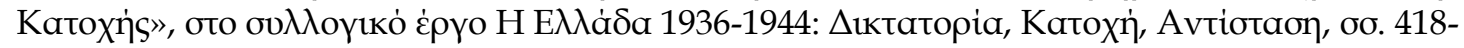
450. 
прихватили југословенски предлог да се организују словенски Македонци у побуњеничке групе са комунистичким вођством. Комунистичка партија Грчке је невољно пристала, треба се рећи, и на крају је била у праву, зато што се убрзо организација СНОФ272, коју је формирала, отргла ван њихове контроле. Да се закључити да је ова организација убрзо потпала под југословенски утицај и погоршала односе између грчких и југословенских комуниста, који су од тада сматрани сумњивима за експанзионистичке погледе према грчкој Македонији. Тензије су се повећале на лето 1944. године са борбама које су избиле између SNOF-a и ЕЛАC-a 273 . Сличан опрезан став у вези са македонским проблемом су држали грчки комунисти и према бугарским герилцима који су пропагирали стварање независне Македоније као посебне балканске државе 274.

Као што видимо, свака велика сила и свака заинтересована избегличка влада имала је другачије решење на уму. Све потешкоће су изашле на видело у тренутку ослобођења, у периоду сарадње левичарског покрета Грчке са избегличком владом према одредбама Либанског споразума. Југословенска Македонија је 2. августа 1944. године званично постала држава, будући члан Федеративне Југославије. Овим чином, Тито се надао да ће ставити грчку и бугарску област Македоније под југословенску контролу, позивајући непосредно Македонце да реагују. Карактеристично је то да је у новембру исте године М. Ђилас изјавио: „Питање уједињења се данас поставља пред македонски народ који има права да буде уједињен, где год се

272. О оснивању и деловању СНОФ-а види Е. Kofos, Nationalism and Communism in Macedonia, Thessaloniki, 1964, oo. 123-128.

273. О оснивању СНОФ-а и његовом распаду види Е. Barker, Macedonia: its Place in Balkan Power Politics, Royal Institute of International Affairs, 1950, об. 110-112. О званичном ставу КПГ према грчко-југословенским несугласицама у вези Македонског питања види П.

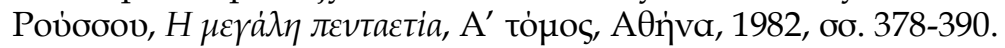

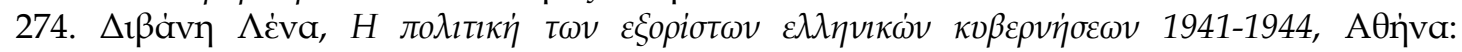

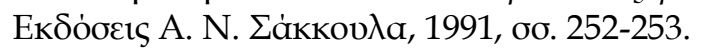


налазио“275. Ситуација је постала много компликованија почетком септембра, када је комунистички фронт отпора Бугарске дошао на власт, изазивајући панику међу грчким комунистима из разлога претеране совјетске подршке којом је располагала. Министри ЕАМ-а су чак предложили Папандреу да се приближи Совјетском Савезу с циљем да обезбеди њихово посредовање како би се повукла бугарска војска из Македоније 276.

Бугарска војска је, 19. септембра 1944. године, пала под совјетску команду, и наређено јој је да пресече немачку војску која се повлачила из Грчке и Југославије. Британци, који су држали избегличку владу изоловану у Казерти, не могу да је смире објављујући још увек тајни план о слању војске у Грчку. Једино што има је било обећано било је да ће се поставити неприкосновен услов за потписивање бугарског примирја, а то је повлачења њених трупа из грчких области које су биле под окупацијом 277 . И заиста, 15. септембра је британска влада послала понуду Совјетском Савезу да се евакуишу грчке и југословенске области које су биле окупиране од стране Бугарске пре било каквих преговора са њом. Совјетска влада је прихватила понуду. ТАСС је, 11. октобра 1944. године, објавио да је Бугарска одлучила да напусти ове територије у року од 15 дана. Грчке територије су до 26. октобра биле готово потпуно евакуисане, међутим напетост је још била велика. Разлог томе је овог пута био споразум између Тита и Бугара да остане део бугарске војске на југословенским територијама с циљем да се заједничким снагама боре против Немаца. Овај развој догађаја је много забринуо Форин офис који је веровао да је Тито, уз совјетски благослов, подстицао стварање словенске федерације започињући уједињавањем Бугарске и Југославије278. У извештају од 30. новембра 1944. године Форин офис је

275.У наставку је био још јаснији, наводећи да је уједињене Македоније од суштинског значаја за његову земљу (E. Kofos, Nationalism and Communism in Macedonia, Thessaloniki, 1964, oo. 135-136).

276. F.O. $371 / 43610$, R 14438.

277. F.O. $371 / 43610, \mathrm{R} 15577$.

278. F.O. $371 / 43611$, R 16492 , R 17072 
изнео своју одлуку да се бори против таквог развоја ситуације, зато јер би се тако Грчка изолована и Бугарска би сасвим избегла последице својих акција током рата 279 .

Почетком октобра Л. Ламбрианидис је постављен за изасланика избегличке грчке владе за регионе Источне Македоније и Тракије. Треба да нагласимо да су левичарски и грађански политичари били у савршеној хармонији што се тиче става према бугарском проблему. Ово слагање је потпуно нестало неколико месеци касније, почетком грађанског рата који је изазвао немир у региону све до краја те деценије. У кратким цртама, можемо описати политику коју је Грчка влада јасно спроводила према Бугарској. Преласком Бугарске у последњем тренутку у савезнички табор, није могуће избрисати њену одговорност за учешће у рату на страни Немачке, нити да промени њен положај као поражена држава. Грчка је у периоду од 30 година претрпила три напада од стране Бугарске. И поред свега овога, Грчка не тражи брисање Бугарске, али захтева да има права да добије граничне и друге гаранције, које ће јој осигурати безбедност од дугогодишњих нереда на Балкану које је начинила Бугарска, и које ће приморати исту да уђе својевољно и с вером у балканску коалицију.

Из изјава према Грчкој влади може се извести закључак да су велике силе делиле исти став, по коме непосредна промена бугарске политике не може да спасе Бугарску од њене одговорности. Иден је, враћајући се из Москве, објавио Цудеросу 7. новембра 1943. године да му је маршал Стаљин, на питање о ставу и очекивањима Руса у вези са Бугарском, рекао да је Бугарска немачка провинција и да могу да јој раде шта год желе. Заменик министра спољних послова Корнечук, у време трајања разговора са грчким амбасадором 7. јануара 1944. године, два пута је изјавио да ако Бугарска убрзо не изађе из рата, уследиће њено пропадање. Форин офис је, у пошиљци намењеној краљевском

279. Њихов изговор је био да је и Совјетски Савез саботирао Балканску Унију да не би био изолован (F.O. 371/43649, R 19712). 
посланству у Лондону, објашњавајући изјаве заменика министра у скупштини заједнице, Лоа, из 24. марта 1944. године, којима се осуђују напади Бугарске на Грчку, изјавио је да „која год се Бугарска влада буде налазила на власти, Бугарска треба да се сматра одговорном за оним што је учинила“. Сличну резервисаност за одговорност следбеника Немачке, невезано за њихов излазак из рата, изражавају у својој изјави из 12. маја 1944. године Велика Британија, Русија и САД.

Грчке претензије према Бугарској су базиране на неоправданој заплени грчких територија, што се генерално карактерише као неизазвана агресија против Грчке, и на почињеним злочинима над грчким становништвом, који су изазвали јавно изражавање гнева од стране надлежних органа савезничких влада. Предуслов за Грчку за било какво примирје са Бугарском је моментална евакуација окупираних грчких терироторија од стране Бугарске, за што су три велике силе усмено обавезале према Грчкој. Грчке претензије према Бугарској су детаљно исказане у облику услова примирја у телеграму под бројем 17523 Председника владе, од 12. августа 1944. године, упућеног грчкој амбасади у Лондону. О питању економског излаза Бугарске на Егејско море, Грчка неће прихватити никакве преговоре док се прво не испуне њене претензије према Бугарској280.

На Конференцији о миру Грчка је затражила одштету у вредности од 700.000.000 долара за штету која је изазвана у периоду бугарске окупације. На крају је добила само 45.000.000. Њен захтев за исправку границе са Бугарском није био прихваћен. Уместо тога, морала је да се брани када је Бугарска прешла у напад тражећи излаз на Егејско море, али без успеха 281.

280. А.Ү.Е. (Архив Министарства спољних послова) Коßв́рvпоп Каїроv 1944, III, 42.2, «Booגүapia».

281. О грчким и бугарским захтевима на Мировној конференцији види D. Constantopoulos, The Paris Peace Conference of 1946 and the Greek-Bulgarian relations, Institute

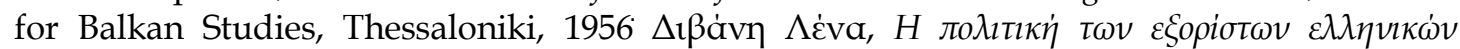

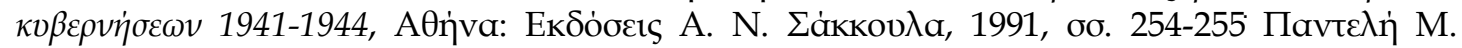

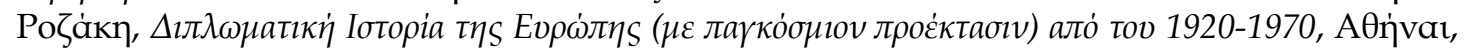

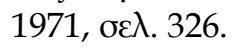




\subsection{2 МИРОВНИ СПОРАЗУМ САВЕЗНИКА СА БУГАРСКОМ И СТАВ ГРЧКЕ ВЛАДЕ}

Резиме ставова Грчке владе према бугарском примирју представљен је у саопштењу од 10. новембра, упућено енглеском амбасадору у Атини, које је допуњено коментарима Председника владе. Копије текстова су такође послате америчком амбасадору. Будући да совјетска амбасада још увек није бла отворена у Атини, документ који је намењен њој послат је у Каиро. Саопштење Грчке владе одговара на допис енглеске амбасаде од 27. октобра, којим је представљен Грчкој влади план примирја који је потписан следећег дана. У њој се изражава непријатно изненађење грчке владе које је уследило након ишчитавања услова примирја, који су потврђивали теорију о невиности бугарског народа наспрам кривице њених влада. Ово је за Грчку неприхватљиво, јер народ се није у ниједном тренутку суштински успротивио таквој политици, већ ју је и сам подржавао прижељкујући победу Немачке, доказујући тако и дволичност данашњих бугарских владајућих политичара који играју улогу посматрача који, према тренутном интересу, аплаудирају једној или другој страни. Против оваквог става уздиже се протест грчког и југословенског народа, уз напомену се да је бугарска издаја била један од главних узрока страдања грчког народа. Позивајући се на дописе у току септембра, којима су савезници обавештени о минимуму услова који су се тицали грчких претензија, Грчке је одлучна да истраје све док не издејствује оне територијалне гаранције које ће је обезбедити од Бугарске282.

Теорија којом се покушава подржати ослобађање кривице бугарског народа је потпуно неприхватива за Грчку. У периоду од тридесет година Бугарска је напала Грчку три пута и два пута велике силе, на чијој се страни Грчка бори и данас. Међутим, бугарски народ

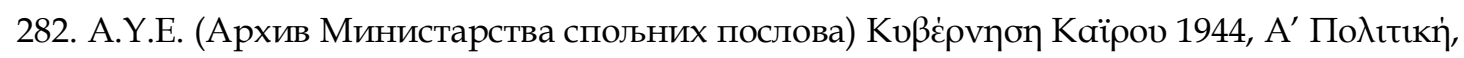
$38.1, \mathrm{~B} / 13$. 
никада није показао ни најмање противљење због такве неправедне политике. Насупрот томе, својом подршком је јачао владе, с времена на време, које су имале освајачке аспирације на рачун суседних народа. Овакав став бугарског народа не може представљати гаранцију за Грчку да се слични издајнички подухвати неће поновити у будућности. Не постоји сумња да су сви Бугари до једнога јако прижељкивали победу рајха, јер би само у том случају могли да се надају да ће сачувати територије које су силом преотели од Грчке и Југославије. Да бугарски народ има осећај дужности према слободи и правди, требало је да се угледа на пример грчког и југословенског народа, који су се побунили против војски које су их напале.

Исто важи и за садашњу владу Бугарске, која је имала став хладнокрвног посматрача за све време дугог периода предаје Немачкој. Била је спремна да поздрави евентуалну победу Немачке, али истовремено је била спремна, као што сада чини, да преузме улогу искреног пријатеља савезника и критичара политике коју је њена земља следила до пада Немачке на Балкану. Њен циљ је очигледан - да Бугарска изађе нетакнута из ове авантуре, у коју је ушла сасвим добровољно. Бугарска издаја је била одлучујући фактор за незапамћено искушење у којем се нашла Грчка, која је без оклевања заузела свој положај у против окупатора у најнеизвеснијем тренутку рата.

Грчка влада је одлучна да истраје енергично како би постигла оне територијалне гаранције које ће у будућности трајно онеспособити Бугарску да нашкоди неком суседу, и које ће у потпуности обезбедити Грчку од исте. Биће још истрајнија у својој борби јер верује да на овај начин служи, не само својим интересима, него и интересима својих великих савезника, као и општем миру 283 . План примирја Савезника са Бугарском по члановима изгледа овако:

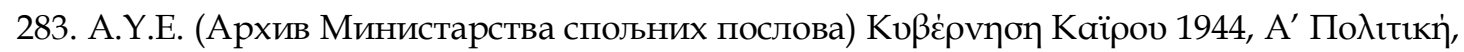
38.1, B/13. 
Члан 1. Бугарска ће прекинути сваку везу са Немачком и осталим непријатељским земљама, разоружати и ограничити непријатељске снаге и њихове држављане, и преузеће под своју контролу сваку непријатељску имовину.

Члан 2. Бугарске снаге, државни службеници и њени грађани ће одмах бити повучени са свих савезничких територија, које су окупиране од стране Бугарске.

Члан 3. Врховна Савезна Команда ће имати право да уводи и слободно покреће савезничке снаге унутар и кроз бугарске територије о трошку Бугарске, ако то захтева стратешка ситуација, или ако Бугарска влада не успе на било који начин да испуни услове примирја, или да надгледа испуњење услова.

Члан 4. Бугарска ће извршити примену било којих мера разоружавања и демобилизације у случају да јој то буде тражено, и предаће све своје наоружање и опрему, ако се то од ње буде захтевало.

Члан 5. Бугарска ће ослободити своје ратне заробљенике савезничких нација и вратиће их у њихове домовине о свом трошку.

Члан 6. Бугарска ће се ускладити са савезничким захтевима за коришћење и контролу транспорта, укључујући и пловне путеве Дунава и олакшице у транспорту.

Члан 7. Бугарска ће пустити на слободу сва лица која се држе из политичких разлога или услед посебних законских одредби. Законодавне мере овог типа се укидају.

Члан 8. Бугарска ће учествовати у хапшењу и довођење пред суд лица која су осуђена за ратне злочине.

Члан 9. Бугарска ће вратити сву имовину која припада Уједињеним Нацијама и обезбедиће одштете за ратне штете које су проузроковане било од војске или од стране појединаца и неће употребити било који део њихове имовине без сагласности Уједињених Нација. 
Члан 10. Бугарска ће на сваки начин, на државном нивоу или приватно, допринети у здравственој и социјалној помоћи и реизградњи у мери која ће бити захтевана од стране савезника.

Члан 11. Бугарска ће обезбедити онолико средстава, служби и услуга и онолики износ домаће валуте који буду захтевали савезници, да се искористи за њихове снаге или њихову мисију у Бугарску, или за наставак рата.

Члан 12. Бугарска ће се ускладити са било којим даљим савезничким мерама, како би се применило примирје. Пружиће све олакшице мисијама које желе да изврше савезници, или Контролним комисијама, које ће Савезници сматрати потребним да формирају. Одазиваће се на све потребе савезника да поврати мир и безбедност и обезбеђиваће сваку гаранцију која буде била захтевана од ње за овај циљ 284.

У току разговора о строгим условима који ће бити наметнути Немачкој, неприхватљиво је да Бугарска изађе нетакнута из једне кризе која је шокирала свет и за време које је иста играла толико стравичну улогу. Ако Бугари, који су смишњено и прорачунато стали на страни снага Осовине, буду имали попустљив и толерантан третман, а заслужују најстрожију казну, то ће представљати опасан преседан и огромну неправду. Логично је да би такав развој догађаја грчком народу проузроковао, не само велико разочарење, већ и утисак да је његова жртва била узалудна.

Минимални услови гаранција које, по мишљењу Грчке владе би требало да буду укључени у одредбе бугарског примирја, су у складу са осећајем моралности и правде, вођене потребом да се обезбеди Грчка од сваког новог напада и предаторске агресије Бугара, и из потребе за обновом грчког становништва, које је било протерано из својих домова, и

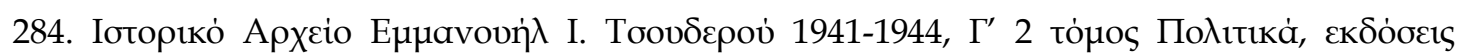
Фитра́кฤ, бо. 1217-1218 Архив Србије и Црне Горе (Југославије), 370, Ф 25, бр. 74, Посланство К. Ј. у Турској-Цариград, Анкара 1919-1945, Бугарска 1944 и 370, Ф 27, бр. 28, Посланство К. Ј. у Турској-Цариград, Анкара 1919-1945, Грчка 1939-1945. 
да се коначно отпочне суштинско поправљање нанетих штета. Грчка влада сматра за своју дужност да инсистира на томе да се њене примедбе требају узети у обзир и да се требају мењати услови примирја 285.

Не извршавање моменталне демобилизације бугарске војске свакако не представља претњу Грчкој, будући да се трупе савезника Совјетског Савеза налазе у Бугарској. Међутим то представља награду Бугарима за подмуклу политику коју су следили како би избегли правичну казну за ужасне злочине које су починили. Бугари су мислили да ће моћи да преваре савезнике, прелазећи на њихову страну у последњем тренутку, након што су већ помогли Немачкој свим својм средствима. Осим тога, од тренутка када је Бугарска постала независна држава, увек је била на немачкој страни, било у рату или миру.

Нигде се не помиње питање разоружавања Бугарске. Ово представља врло озбиљан и врло опасан пропуст. Грчка, која је у последње три деценије претрпела три неиспровоцирана напада од стране Бугара, већ је разоружана од стране њених непријатеља. По завршетку рата, против сасвим ненаоружане Грчке, Бугарска би била спремна, и под пуном ратном спремом., да што је пре могуће крене у нови напад против својих суседа. Разоружавање Бугарске у овом тренутку, и предаја ратног материјала савезницима је мера која је потпуно неопходна 286.

Нема ни речи о обавезама Бугарске и трошковима које треба да предузме за обнове домова грчког становништва који су били отети или премештени, са различитим изговорима, на бугарску територију. Такође, нема речи о преузимању трошкова од стране Бугарске за повратак и поновно насељавање грчког народа у своје домове, који су били присиљени да их напусте због бугарских злочина, и који су избегли на разна места у Грчкој, где се још увек налазе као избеглице.

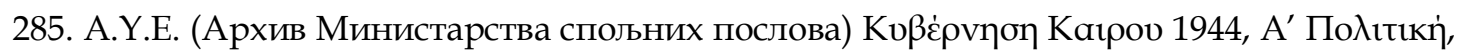
38.1, B/13.

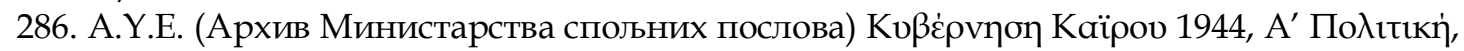

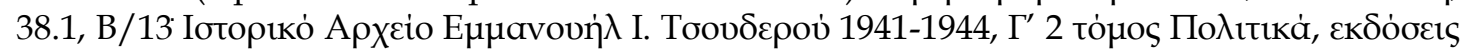

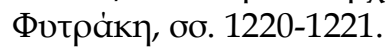


Члан 9 уопште није категоричан у односу на обавезу Бугарске да надокнади губитке и штете које су нанете Грчко у ратним дешавањима. С обзиром да су Бугари предузимали, поред ратних операција, и систематско уништавање на територијама које су били под њиховом окупацијом, уништавања која су довршили током свог повлачења, неопходно је да им се јасно наметне обавеза да плате одштету, без изузетка, за све губитке и штете које су изазавали све до њиховог повлаћења. Требало би, у вези са овим, да се у члан 9 додају обавезе Бугарске да плати накнаде за ратне штете, укључујући и штете настале од стране бугарских побуњеника или цивила. Доказано је да су, у име комита, познате бугарске банде криминалаца интензивно учествовали у истребљивању грчког становништва, и у уништавањима. Одувек су Бугари користили комите за организовани прогон и уништења, сваки пут када су желели да избегну било какву одговорност мешања од стране војске и владиних институција.

Неопходно је да се Бугари обавежу да размене бугарски новац који ће се наћи у рукама становника регија које су окупирали, са сумом која ће бити исплаћена у злату или другој стабилној страној валути, у вредности коју је имала бугарска валута пре агресије.

Нигде се не помиње учешће грчког представника у, предвиђеним под чланом 18, Савезничким Контролним комисијама. Међутим, чак и површним ишчитавањем разних чланова примирја види се да је већина њих непосредно везана за Грчку и њене највиталније интересе. Грчка је била главна жртва прогона и уништења које је произвело бугарско дивљаштво. Потражња и ослобађење десетине хиљада Грка расељених или присилно отетих из Бугарске под разним изговорима, потраживање и повратак имовине која им је одузета, праћење активности Бугарске и тачно извршавање услова примирја од стране Бугара, чине неопходним присуство грчких представника у Савезничким контролним комисијама. Упркос искреним напорима савезника, било би немогуће, да без помоћи грчке делегације осујете покушаји обмањивања од стране Бугара у циљу 
спречавања откривања истине о отетим људима у Бугарској, који су касније задржани као таоци, или послати на принудни рад. Ово питање је потврђено и дешавањима у последњем рату. У складу са свим овим, намеће се моментално учешће грчког представника у Савезничкој контролној комисији.

У параграфу 5 протокола, који се налази у додатку примирја, наводи се обавеза Бугарске владе о обезбеђивању хране како би се обезбедило угрожено становништво које је под бугарском окупацијом. Међутим, не помиње се обавеза о непосредној достави количине неких других производа, као нпр. пољопривредних машина и алата, горива, семена, производа потребних за пољопривреду и обраду земље, транспортна средства, без којих би било немогуће да заживе области које су погођене бугарским нападима и агресијама и које су лишене свега за време трајања окупације. Било би у супротности правди и идеалима за које се боре Уједињене Нације, ако би се догодило да окупатор и уништавач савезничких територија остане некажњен, несметано уживајући у плодовима отмице и кривичних дела, док би становници истих ових територија које је уништио наставили, и после победе, да живе у сиромаштву и беди.

Не спомињу се никакве казне за евентуално неизвршавање одредби из овог примирја. Изоставњено је да се наведе у тексту примирја да ће Бугарска унапред прихватити било коју одлуку везану за територијалне промене, или друге услове, чија ће извршења тражити Савезници у циљу поновног успостављања трајног мира на Балкану, као и безбедност Бугарских суседа од било ког поновног напада од исте или преко њене територије $\mathrm{e}^{287}$.

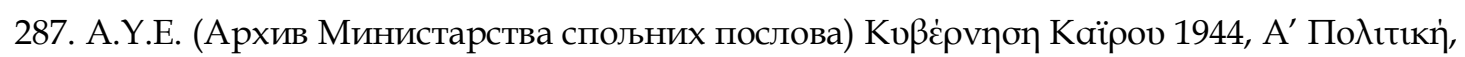

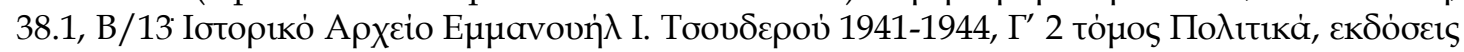
Фитра́кฤ, бо. 1221-1222. 


\section{4 ГРЧКО-ТУРСКИ ОДНОСИ}

\subsection{1 ГРЧКО-ТУРСКИ ОДНОСИ У ДРУГОМ CBETCKOM РATY}

Венизелос и Кемал Ататурк, од 1930. године па надаље, покушали су да створе један заједнички фронт пријатељства и сарадње како би се заштитили од планова великих сила. Одмах након закључења грчкотурског споразума о заједничкој одбрани, Генерални савети обе земље почели су да раде на заједничким плановима одбране који су обухватали Тракију, Босфор и Северни Егеј. Две државе су сарађивале у једној пријатној атмосфери у доменима економије, политике и културе са позитивним резултатима. Смрт турског вође и визионара Кемала Ататурка, у новембру 1938. године, је свакако био лош знак и сматрано је да ће имати јак утицај на даљи ток грчко-турских односа. Било је јасно да је његов наследник Исмет Инену, турски преговарач у Лозани, и поред својих уверавања у супротно 288 , био одлучан да примени још чвршћи став у спољној политици претендујући на територије у име Турске289.

Нови председник Турске Исмет Инени се постепено удаљио од традиционалних смерница Кемалове спољне политике, а посебно по питањима која су се тицала грчко-турских односа. Чак и пре смрти Кемала Ататурка, Инену се није слагао са начином решавања битних тема, као што је био случај Александрете (1937-1938) и ревизија режима

288. Према информацијама енглеског амбасадора у Атини сер Сиднеја Ватерлоуа, Метаксас је за време посете Анкари, због сахране Ататурка, разговарао је на тему грчкотурских односа са новим председником Турске. Инени је том приликом уверавао грчког диктатора да ће следити исту политику према Грчкој коју је имао и његов

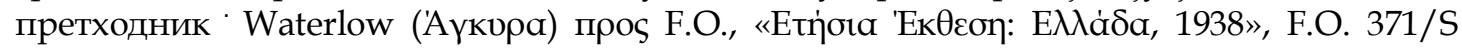
886/886.

289. Инени је био на лошем гласу у националистичким круговима јер су сматрали да је дозволио распарчавање турске империје у Лозани. Такође, није био омиљен ни међу бројним генералима и политичарима. Сматрао је да ће оваквом политиком захтевања

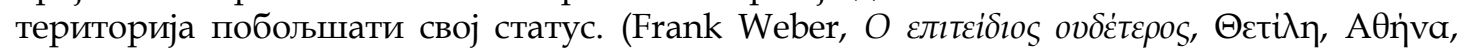

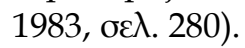


Босфора (1936), са резултатом да се нађе ван владе 1937-1938. године 290. Одступања у области спољне политике су постала израженија од јануара 1939. године, када је Инену заменио искусног министра Иностраних Послова Турске Ружди Араса и поставио на његово место Шукру Сарачоглуа ${ }^{291}$. Међутим, преусмеравање нове Иненине спољне политике је посебно изражено у мрежи грчко-турских односа. Уздржаност нове Турске владе да додатно прошири грчко-турске односе изразио је у Атини, у фебруару 1939. године, турски министар спољних послова Шукру Сарачоглу292, који је постао познат у Грчкој због свог бескомпромисног става у току грчко-турских преговора у периоду од 1924. - 1929. године. У новембру 1939. године Турска је негативно одговорила на предлоге грчког Генералног савета за потписивање војног споразума, као и за стварање јединственог војног фронта у Тракији, способног да одбије један бугарски или немачко-бугарски напад 293. Грчко-турски преговори, који су се наставили и првих месеци 1940. године, пропали су због турских недоумица. Нови став Турске владе је изазвао озбиљну забринутост у Атини, пошто је турско савезништво од 1930. године сматрано темељом грчке одбране, у складу са политиком коју је покренуо Елефтериос Венизелос, и коју су наставили да прате Панагис Цалдарис и Јоанис Метаксас.

Грчко незадовољство делили су Енглези и Французи, са којима је Анкара потписала споразум о савезништву 19. октобра 1939. године. Овим споразумом Турска је предузела обавезу, у случају улаза сила

290. У том периоду за премијера Турске је постављен Селал Бајар. За подробнију анализу политичких размирица за време Кемала Ататурка види Ismet Bozdag, To

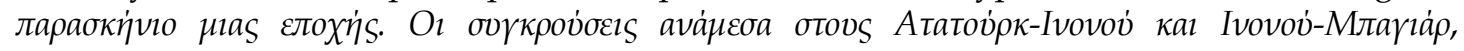
Кஸvotavtıvoúnо $\eta$, 1972, бо. 108-111.

291. Арас је био главни представник врло активне турске политике у периоду 1928-1938. године, која је довела Турску ближе енглеско-британској коалицији. Арас је предводио уласком Турске у Лигу народа (1932), поновном уређењу питања демобилизације Босфора (1936), као и референдума у области Александрете (1938). Такође, имао је значајну улогу у грчко-турском зближавању и стварању Балканског споразума (1934). За детаљније информације види. D. A. Rustow, «Foreign Policy of the Turkish Republic»

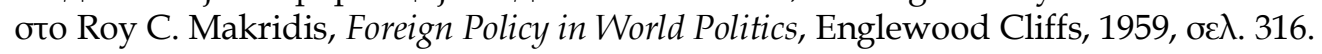

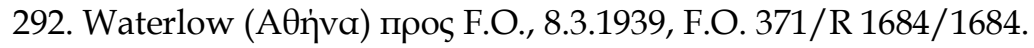

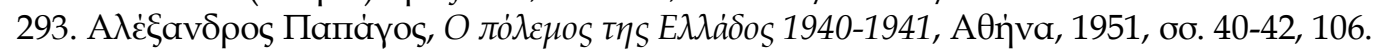


Осовине у простор Средоземља, да пружи Енглеској и Француској сву помоћ и подршку која би била у њеној моћи. Штавише, када је Италија прогласила рат против Енглеске и Француске у јуну 1940. године, Анкара не само што је остала неутрална, него је и наставила своје трговинске везе са Италијанима294. Сасвим исти став је имала и када је, четири месеца касније, Мусолини напао Грчку. Према члану 3. енглескофрансуско-турског споразума о савезништву, Анкара је била у обавези да помогне Грчкој, која је била покривена енглеско-франсуском гаранцијом од 13. априла 1939. године. Само три дана након италијанске инвазије, турски председник, објашњавајући став своје земље, изјавио је да је Турска, упркос чињеници да у датом моменту није спремна да се ангажује у рату, остаје верна својим обавезама и пријатељима295. Министар Спољних послова Сукру Сарацоглу је, 6. новембра 1940. године, потврдио грчком амбасадору Рафаилу Рафаилу да би један координирани бугарско-немачки напад против Грчке значио casus belli за Анкару 296 . Исти положај је заузео и турски амбасадор у Атини Енис Акауген, у разговору са америчким колегом Линклолном МекВигом²97. Истовремено је Турска влада дозволила прелазак на стотине Грка из Константинопоља на италијански фронт. Окупљање добровољаца је организовао почетком новембра Савез Грка у Константинопољу, уз сагласност Турске владе 298 . Под оваквим околностима Атина није имала другог избора осим да се задовољи симболичним гестовима добре воље и уверавањима Анкаре. Ова уверавања је турски министар Спољних

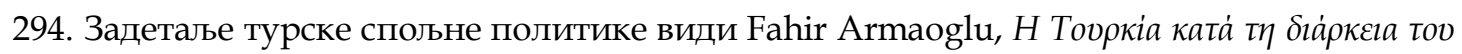

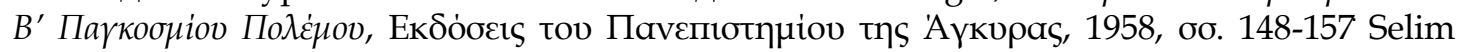
Deringil, «The Preservation of Turkey's Neutrality During the Second World War: 1940», Niddle Eastern Studies 18, 1982, oo. 29-52.

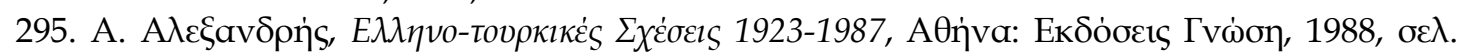
85.

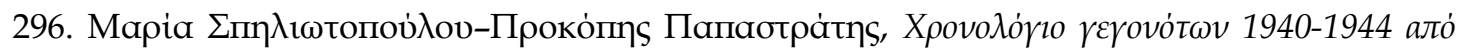

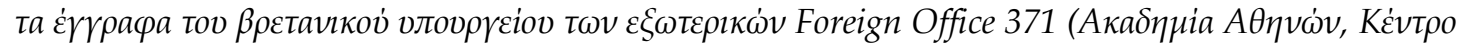

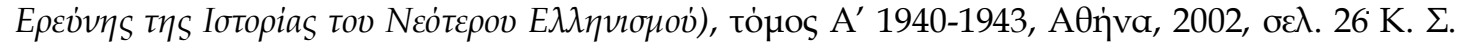

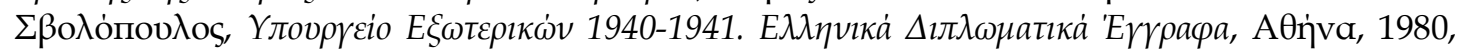

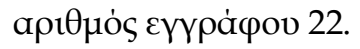

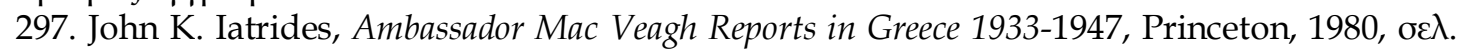
252.

298. The Times 10.11.1940. 
послова, Шукру Сарачоглу, поновио 19. јануара 1941. године, за време радног ручка са енглеским амбасадором у Анкари, Канчбулом Хугесеном, објашњавајући да ће Турска ући у рат у следећим случајевима: ако иста буде нападнута од било које стране силе; ако Грчка буде нападнута од стране Бугарске или Немачке, преко бугарске територије; ако се лука у Солуну доведе у опасност ${ }^{299}$.

Будући незадовољан овим вербалним уверавањима, енглески премијер Винстон Черчил је, 31. јануара 1941. године, упутио писмо Исмету Инену. У њему га је упозорио да је продирање Немаца у Бугарску толико напредовало да ће ускоро Берлин да буде у положају да произвољно намеће своју вољу, приморавајући Софију да уступи своје територије за напад на Солун, грчке авионске базе и острва Егејског мора. Један такав сценарио, упозорио је Черчил, би значио и изолацију Турске. Како би се избегла оваква ситуација, енглески вођа је предложио да Турска уступи у Источној Тракији олакшице Енглеској, сличне онима које су биле уступљене Немачкој у Бугарској ${ }^{300}$. Турска је још једанпут одговорила неодлучно, са изоговором да тражи више гаранција и војну помоћ од Енглеске 301.

У међувремену, почетком фебруара 1941. године, немачке трупе су се постројиле дуж границе Тракије. Престрављена због оваквог развоја догађаја, Турска је пожурила да 17. фебруара потпише заједничку бугарско-турску изјаву, којом су две државе међусобно утврдиле као основ њихове спољне политике спречавање било каквог међусобног напада, као и унапређивање пријатељских односа између Анкаре и Софије ${ }^{302}$. Овакав развој догађаја је јасно показао да Турска, и поред уверавања, није спремна да се успротиви евентуалном немачком нападу на Грчку преко Бугарске. Управо ово је истакако грчки амбасадор у

299. Knatchbull-Hugessen ('Аүкטра) про૬ F.O., 19.1.1941, F.O. 371/R 481/236.

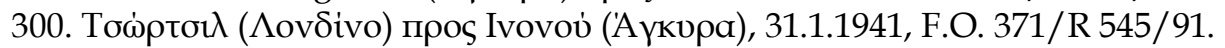

301. Одговор Иненија и коментари Ф.О., F.О. 371/R 871/274 кaı F.O. 371/R 898/236.

302. Текст и коментари Ф.О., F.O. 371/R 3940/91 кaı F.O. 371/R 3941/91. 
Анкари, када се састао са Шукруом Сарачоглуом 22. фебруара 1941. године, изразивши му дубоко незадовољство грчке владе.

Бугарска се, задовољна дешавањима са Турском, придружила Тројном пакту како би постала савезник Немачкој, Италији и Јапану. Забринути због ових дешавања, Британци шаљу трупе у Солун, док су британски министар иностраних послова сер Антони Иден и генерал Дил стигли, 2. фебруара 1941. године у Атину, на преговоре са грчким вођством. Након тога је британска мисија посетила Анкару, пре него што се врати у Атину 18-19. марта 1941. године ${ }^{303}$. На овим сусретима грчка страна је инсистирала на ставу да је учешће Турске у одбрамбеном механизму Тракије било нужно, док је Анкара избегавала било какав разговор на ту тему, карактеришући претераним гледиште да је Немачка била спремна да нападне Грчку. Штавише, Исмет Инени је обавестио Британце да би Турска ушла у рат само у случају напада на Грчку. Истовремено, турски лидер је у писму Немачкој влади уверавао да је његова земља одлучна да сачува своју неутралност ${ }^{304}$.

Када је, коначно, Немачка извршила инвазију на Грчку 6. априла 1941. године, Грчка влада је схватила да добри грчко-турски односи и позитивна клима на Егеју неће преузети облик конкретних подухвата од стране Турске. Велико разочарење у Атини је изазвао догађај када су Турци, након немачког напада, повукли своје трупе са турско-бугарске границе, дајући на тај начин Немцина могућност да окупе сву своју војску на фронтовима Македоније и Западне Тракије. У исто време, турски министар спољних послова одбијао је британски предлог да приступи бар једном симболичном дипломатском чину који би изразио осуду Турске због координираног напада против грчког народа. Тврдња председника Иненија да је његова земља следила строгу неутралност,

303. За ток ових преговора види А. Alexandris, «Turkish Policy towards Greece during the Second World War and its Impact on Greek-Turkish Relations», Balkan Studies 23/1, 1982, бо. 179-180.

304. Тврдња да Турска није могла да учествује у рату услед недостатка војног материјала и опреме често је изражавана од стране турских историчара. Види Turkkaya Ataov, Turkish Foreign Policy, 1939-1945, 'Аүкора, 1965, об. 81-89. 
била је у супротности са обећањима која је преузела Турска потписивањем Балканског Споразума из 1934. године и грчко-турских споразума 1933. и 1938. године, као и Британско-француско-турског пакта из 1939. године 305.

Опортунистичко деловање турске дипломатије се наставило у јуну 1941. године, када је Турска потписала пријатељски и трговачки споразум са Немачком ${ }^{306}$. Поред позива Енглеза и сталног допремања помоћи, Исмет Инени је задржао земљу неутралном, извозећи хром у Немачку и захтевајући од савезника претеране количине војне опреме у замену за обустављање неутралности. Турска страна покушава да оправда овакав став позивајучи се да Турска у том периоду има једини циљ очување своје неутралност за све време трајања рата, како би остао ненарушен њен национални суверенитет ${ }^{307}$.

Међутим, постоје необориви докази који сведоче да је Турска, систематски и врло пажљиво, преговарала и са Енглеском, и са Немачком о свом уласку у рат зарад територијалног добитка ${ }^{308}$. У овим преговорима Турци нису захтевали само територије, као нпр. Бугарску Тракију, Крим, Транскавказију, него и права наметања власти у Сирији, Ираку, Египту и Албанији. Имали су такође у својим прохтевима да добију области, као што су грчка острва у Источном Егеју, Додеканез, Кипар, као и контролу над луком у Солуну, захтев који ни Кемал Ататурк, пореклом из Солуна, није никада поставио ${ }^{309}$. Претензије које је изнела Турска влада у периоду од 1939-1943. године, имале би за

305. Амерички мабсадор у Атини Линколн МекВиг забележио је: „Морам признати да сам увек сумњао у Исмета. Да је још међу живима Кемал верујем да би Турска, са њим на челу, учествовала у рату."; John K. Iatrides, Ambassador Mac Veagh Reports in Greece 1933-

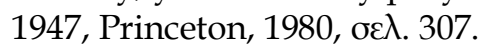

306. Од краја 1938. године Турци покушавају да потпишу споразум о пријатељству са Немцима, који су одбијали такав споразум да не би „отерали“ Арапе.

307. Овакав став деле и многи амерички аутори, види. E. Weisband, Turkish Foreign Policy,

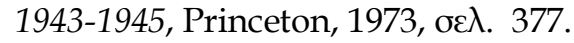

308. За детаље турских преговора са ове две земље, засноване на енглеским и немачким

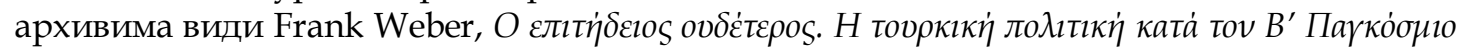

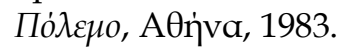

309. За претензије на штету Грчке види A. Alexandris, «Turkish Policy towards Greece during the Second World War and its Impact on Greek-Turkish Relations», Balkan Studies

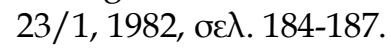


резултат поновно оживљавање Отоманског Царства. Такође дају јасну слику колико је дубоко укорењен дух Отоманског царства у новој националистичкој Турској.

Анкара је, захваљујући територијалним разврставањима које су се догодиле у једном периоду глобалне несигурности и сукоба, покушала да се ослободи ограничења која су јој била наметнута Споразумом из Лозане, колико на Егеју и Балкану, толико и на Средњем Истоку. Поврх тога, председник Инени, који је сматран од екстремних националниста издајицом и оптуживан да је предао територије царства суседима Турске за време преговора у Лозани, помислио је да уграби ову прилику да поврати своју високу репутацију 310 . Штавише, након немачке окупације Грчке, Иненина влада је уназадиле дипломатске односе са Грчком избегавајући да одреди амбасадора у избегличкој Грчкој влади у Каиру од 1941-1943. године. Турске територијалне претензије над грчким областима у периоду трајања Другог Светског рата представљају први пример турских експанзионистичких намера у области Егејског мора ${ }^{311}$.

Турци су одржали ову двосмислену неутралност готово све време трајања рата, циљајући на то да што је више могуће да искористе ситуацију у своју корист, а да не доведу у опасност нити свој територијални интегритет, нити свој углед ${ }^{312}$. Тако су вештим маневрима пре рата успели да се у њихову корист изврши ревизија режима Босфора 1936. године и да преузму Александрету. Касније, док се рат

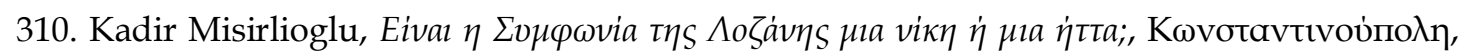
1965.

311. A. Alexandris, «Turkish Policy towards Greece during the Second World War and its

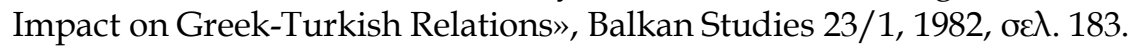

312. Постоје и друге, мање убедљиве тероије у вези са овим питањем. Једна од тих припада Едварду Висбанду (Turkish Foreign Policy 1943-1945: Small State Diplomacy and Great Power politics, Edward Weisband, Princeton, 1973). Он приписује турску неутралност њиховом страху од совјетске тенденције проширивања. То значи да је Турска покушала да одржи неку врсту равнотеже сила, да не би дошло до безусловне предаје Немачке, што би значило да не постоји никаква баријера совјетском продору.

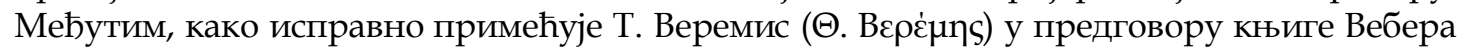

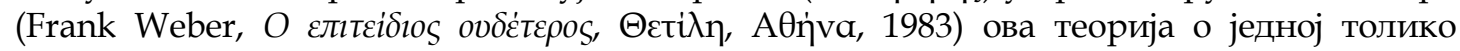
визионарској Турској није убедљива, јер је коначан исход рата била велика

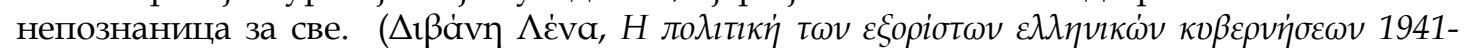

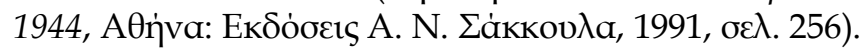


распламсавао оставили су два противничка табора да се боре разним понудама да задобију њихово савезништво, пошто нису били у стању да их приморају да уђу у рат ${ }^{313}$.

Турска је према Грчкој такође задржала један дволичан став. С једне стране, у преговорима са Немцима и Британцима је захтевала да добије контролу над Додеканезом, нешто што је било познато да је било незамисливо за Грчку. С друге стране, охрабривала је грчку заједницу у Турској да помогне у рату своје сународнике. Са званичном дозволом од стране Турске, Удружење Грка Константинопоља је организовало мисију добровољаца. Комисија сачињена од угледних Турака, Грка, Јермена и Јевреја формирана је у Цариграду с циљем да помогне грчки Црвени $\mathrm{Kpст}^{314}$. Велику помоћ изгладнелим Грцима представљале су пошиљке легендарног брода Куртулус, као и збрињавање, у границама могућег, грчких избеглица од стране Турске.

Тачније, разговори између Форин офиса и Министарства економског рата, које је било надлежно за блокаду Грчке, окончани су почетком јуна 1941. године одлуком да Грчка треба да буде помогнута пошиљкама хране, и да се одмах треба решавати криза прехрањивања становништва. Истовремено је требало очувати ембарго. Најповољније решење је била Турска, пошто су Сирија и Египат из разлога безбедности били искључени из опција. Природне границе Грчке и Турске су дозвољавале превоз хране путем копна, иако се акција одвијала путем мора. Разлог је био да на овај начин неће бити лако уочљиво кршење блокаде. Такође Турска је, као неутрална земља, могла да прода

313. Разлог због којег је било јако тешко да приморају Турску да учествује у рату није била велика војска, коју свакако није поседовала Турска. Разлог је природно утврђење које представља Мала Азија, коју да је хтео неко да освоји платио би велику цену.

314. Alexis Alexandris, «Turkish policy towards Greece during the second world war and its impact on Greek-Turkish detente», Balkan Studies, Vol. 23, No 1, Thessaloniki, 1982, бo. 157197. 
своје резерве хране Силама Осовине, на тај начин су потенцијално спречаване да дођу у руке непријатеља ${ }^{315}$.

Турска се заиста понудила да прода око 50.000 тона хране Грчкој. Куповина би се остваривала преко Британске Трговачке Организације (U.К.С.С.). Превоз је одрађен бродом „Куртулус“, који је из 5 наврата снабдео грчко тржиште са 6.735 тона хране. При шестом путовању је потопљен са теретом од 1.800 тона хране. На његово место је дошао „Дулумбунар“ који је укупно пренео, до марта 1942. године, око 2.500 тона хране. Веома рано је било јасно да Турска не може да буде трајно решење за грчки проблем. Турско тржиште је било озбиљно пољуљано, цене су абнормално скочиле и почели су да избијају на површину први знаци незадовољства јавног мњења. На крају није било могуће да прода Грчкој 50.000 тона хране које је обећала на почетку ${ }^{316}$.

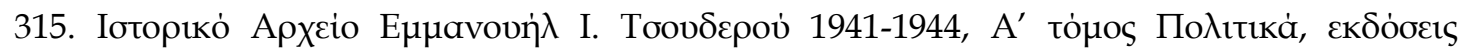

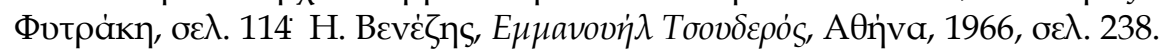

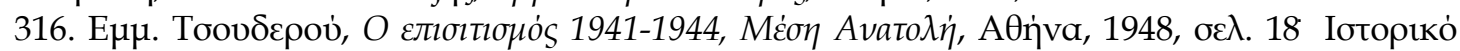

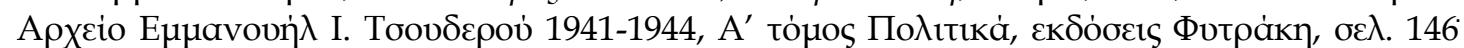

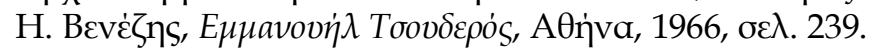




\subsection{2 ТУРСКИ СТАВ ПРЕМА ГРЧКОЈ МАҢИНИ И ПОРЕЗ „VARLIK VERGISI"}

У овом периоду Грчка није хтела да поремети климу помиривања и политичке сарадње између две земље. Као резултат ове политике је била вољност Грчке владе да не дозволи да било какав мањински проблем баци сенку на грчко-турску дипломатску и политичку сарадњу. Са овим ставом, у вези са хијерархијским циљевима грчке спољне политике, слаже се и Форин Офис, бележећи да „је принцип грчке спољне политике да избегава да се бави мањинским питањима која би шкодила хармонији грчко-турског пријатељства“317. Из овог разлога, Грчка влада је водила једну праведну политику према мањинама на простору Западне Тракије, где су муслимани уживали потпуну верску, језичну и културну слободу. У једном детаљном допису упућеном Форин Офису с насловом „Мањине у Грчкој“, енглески амбасадор у Грчкој влади Р.А. Липер нагласио је да је „став према турској мањини Западне Тракије од стране Грка био изванредан“. Разлози за то, према Липеру, били су велики значај који је Грчка придавала пријатељству са Турском, и веровање Атине да би добро опхођење према муслиманима из Западне Тракије навело Анкару да покаже добру вољу према грчкој мањини у Турској ${ }^{318}$.

Насупрот томе, став Анкаре према мањинама се погоршао након смрти Кемала Ататурка, у новембру 1939. године. Посебно после избијања Другог светског рата створена је једна националистичка и непријатељска атмосфера према мањинама, која је одражавала утицај расистичких теорија Сила Осовина у Турској. Распрострањивање ове тенденције, није само толерисала, већ је и охрабривала Турска влада, посебно једна група водећих елитних филгермана Анкаре, као што су

317. A. Alexandris, The Greek Minority of Istanbul and the Greek-Turkish Relations 1918-1974,

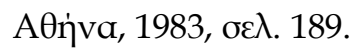

318. «Minorities in Greece» запажања која је спремао Липер (Ка́ıро) упућена F.O., F.O. 371/43775/R 12193. 
министар спољних послова Нуман Менеменцоглу и генерални начелник штаба Февзи Чакмак ${ }^{319}$. Чак и веродостојне новине Џум Хуриет и Тасфир Есфакан су биле под јаким утицајем успеха нациста на Балкану и совјетском фронту 1941-1942. године ${ }^{320}$.

У периоду када су се грчке оружане снаге бориле против заједничког напада Немачке и Бугарске у Тракији и Македонији, Иненина влада је регрутовала, у мају 1941. године, мушкарце немуслиманске вероисповести из Константинопоља, који су били старости од 25-45 година. Ови људи су били смештени у посебне логоре у унутрашњости Мале Азије, где су остајали 40 дана и били чувани од стране турских војника. Касније, прогнано становништво мањина је расељено у различитим правцима да раде на изградњи путева. У децембру 1941. године су демобилисани мушкарци старијег узраста, од 38-45 година, док су остали задржани још 6 месеци преживљавајући тешкоће једне изузетно хладне зиме. Главни циљ Анкаре, у складу са оценом Форин офиса, изгледа да је био премештање мањинског становништва из стратешки осетљиве зоне Константинопоља ${ }^{321 .}$

Вероватно вођена истом политиком, Турска влада је дозволила грчким становницима Цариграда да се сврстају као добровољци у грчкој војсци, и тако су од новембра 1940. године на стотине Константинопољаца напустили Турску и отишли на албански, а касније и на македонски фронт. Тако се Анкара, представљајући овај подухват као помоћ Турске у борби Грка, ослободила од знатног броја нежељених странаца.

Настављајући игру утисака и пријатељских гестова према Грчкој, Турска је тријумфално објавила програм испоруке хране и других неопходних намирница за изгладнелу популацију окупиране суседске земље. Тако је од октобра 1941. године до септембра 1942. године

319. A. Alexandris, «Turkish Policy towards Greece during the Second World War and its Impact on Greek-Turkish Relations», Balkan Studies 23/1, 1982, oع $\lambda .188$.

320. Knatchbull-Hugessen ('Аүкטра) прољ F.O., 19.4.1941, F.O. 371/R 4202/622.

321. Knatchbull-Hugessen ('Аүкира) прољ F.O., 19.5.1941, F.O. 371/R 5357/15. 
преношена помоћ из Константинопоља у Пиреј са бродовима под заставом турског Црвеног Полумесеца. Турски академици су максимално искористили овај потез у циљу ширења пропаганде. Чак је и професор грчког порекла Кицикис уздизао Турке због њихове храбре помоћи. Међутим, чињеница коју многи заборављају да помену је да је овај подухват испоруке намирница организован у великој мери са иницијативом друштвених, хуманитарних, културних и верских удружења Грка у Константинопољу, који су сакупљали прилоге и отварали посебне рачуне за помоћ изгладнелих Грка. Посебне активности је организовало познато удружење „Грчка Унија Константинопољаца“, које је уско сарађивало са грчким амбасадором у Турској Рафаилом Рафаилом ${ }^{322}$. Укупна количина намирница које су се пренеле у Атину је достигла 17.500 тона, што је доста мање од 50.000 тона које је у почетку одобрила влада Анкаре. У децембру 1941. године Турски Министарски Савет је одлучио да забрани даље испоруке хране Грчкој, са резултатом да се концентришу значајне количине жита у магацине турског Црвеног Полумесеца у луци Галатаса 323 . У сваком случају, не можемо да занемаримо лични допринос многих Турака који су били дирнути неравноправном борбом коју је водила тада грчка нација ${ }^{324}$.

Како се погоршавала економска ситуација у Турској, филогермански чланови владе и турска штампа су покренули нову кампању против мањина у Цариграду. Посебно значајну улогу у овој кампањи је одиграо министар Спољних послова, и лични пријатељ председника Иненија, Нуман Нуман Меметџиоглу ${ }^{325}$. Старе расне

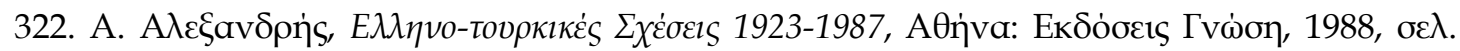
103.

323. Ново погоршавање става турске владе према питању мањина приметно је након смрти премијера Рефика Сајдама, и преузимања владе од стране Сукруа Сарацоглуа,

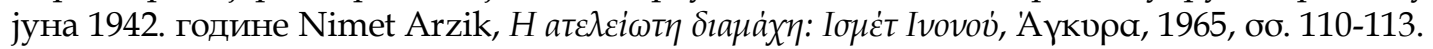

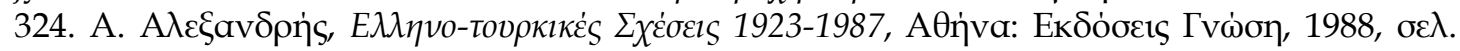
104.

325. Мишљења турског министра у вези са мањинама постоје у телеграму Бенета (Анкара) упућеном Ф.O.; 23.12.1942, F.O. 371/3389/R 8890. 
предрасуде се поново распламсавају под утицајем немачког расизма, који је значајно утицао на турско друштво у периоду од 1939-1944. године. Кампању против мањина је подстицао пантурски покрет који је заживео поново после смрти Кемала Ататурка. Хитлерови обожаваоци су имали пуно заједничких црта са нацистичком идеологијом, нарочито што се тиче расизма и преданости националном социјализму ${ }^{326}$. Ови екстремни националистички кругови, уз охрабрење владе, су успешно стварали утисак да су грчки, јерменски и јеврејски трговци били главни разлог лоше економске ситуације и константног повећања инфлације у Турској. Генерални конзул Грчке у Константинопољу Капетанидис, описујући антисемитску и антихришћанску атмосферу која је преовладавала у Константинопољу, навео је да је добио савет од стране нових турских националиста да, он и његова породица, у међусобним разговорима користе само турски језик. Атмосфера у Константинопољу, наглашавао је грчки дипломата, је постала „неподношљива“327. У једном карактеристичном чланку тог периода, Улус је захтевао ограничавање слобода које су уживале мањине 328.

Чињеница да је Инонова влада драстично уназадила своје односе са Грчком, види се и у њеном покушају да покрене питање Васељенске Патријаршије. Тако је почетком јануара 1943. године турски амбасадор у Лондону Рауф Орбеј, у разговору са својим грчким колегом Атанасиосом Агнидисом, поставио питање зашто Патријаршија није укинута као што се догодило у случају Калифата ${ }^{329}$. Неколико месеци касније Орбеј је упозорио Агнидиса да Анкара неће толерисати мешање Грчке у питање

326. За детаљни истраживање Пантурцизма види Jacob M. Landau, Паvтоvркєбиós: To

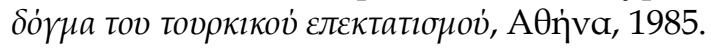

327. Опис ситуације у Константинупољу од стране грчког конзула дат је у телеграму Knatchbull-Hugessen (Анкара) упућеном Eden (Лондон), 8.4.1943, F.O. 371/R 3658/7.

328. Ulus (Нација), 24.11.1942. Наслов овог текста је био: „Георгиосе, нећемо ти дозволити випе да радиш шта хоћеш у Турској“.

329. Белешка Кадогана након разговора са грчким амбасадором А.Агнидисом, Лондон, , 15.6.1943, F.O. 371/37224/R 521. 
Патријаршије, и нагласио је да грчка влада не би требало да га користи за „политичку кампању у корист Грчке, а на штету Турске“330.

Рафаил је, 13. јануара 1943. године, послао телеграм у коме пише да су Митрополити Халкидоне и Имвроса били позвани од стране полиције, где им је наређено да се преместе и остану у Бруси. Грчки дипломата се плашио да су оваква дешавања водила ка истребљењу грчке мањине и предлагао је његову оставку са те функције у знак протеста ${ }^{331}$. Турске власти су, дакле, ухапсиле и депортовале у Прусу двојицу од најцењенијих чланова Светог Синода (Максимоса из Халкидоне и Јаковоса са Имвроса), који су тамо остали четири месеца ${ }^{332}$. Ново заоштравање турске политике према становницима Имвроса десило се у јануару 1943. године, када су градоначелник и троје угледних грађана одведени у Малу Азију након што су протествовали због одузимања имања Свете Горе на Имвросу. И поред учесталих покушаја амбасадора Рафаил Рафаила и последњег манастирског игумана Игнатија Лавриотиса, манастирски поседи су конфисковани, да би на њима били настањени Турци на, до тада, искључиво грчком острву северноисточног Егеја. Цудерос је повезао овај отворени напад са нечим што је недавно био изјавио Турски амбасадор у Лондону. У изјави је стајало да Турска нема никаквих проблема да се одрекне Додеканеза у корист Грчке, под условом постојања и поштовања добрих и пријатељских односа два народа. У супротном, доћи ће до промене турских намера према тим областима. Тако је Цудерос изнео своје сумње Идену да Турска покушава да пронађе разлог да поквари добру атмосферу у циљу покушаја да придобије Додеканез ${ }^{333}$.

Мере против мањинског становништва долазе до врхунца 11. новембра 1942. године наметањем ванредног пореза на имовину (varlik

330. Допис грчке влада према Ф.О. (Каиро), 7.6.1943, F.О. 371/37228/R 5373.

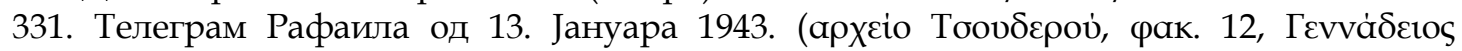

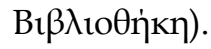

332. A. Alexandris, The Greek Minority of Istanbul and the Greek-Turkish Relations 1918-1974,

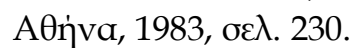

333. F.O. 371/37512, R 735. 
vergisi) ${ }^{334}$. Наметање злогласног закона Varlik Vergisi је имало за циљ да умањи превелику добит трговаца и посредника, и да ограничи инфлацију. У суштини, закон је био једна врста економског и политичког напада на немуслиманске заједнице које су живеле у Турској и које су имале један значајан удео у пословањима и трговини. Још пре званичног доношења закона штампа је припремила терен чланцима против Јевреја и грчких трговаца, за које су навели да послују „на црно“ и окарактерисали их експлоататорима турског народа. Карактеристичан је наслов који је употребио часопис «Ulus» од 24. новембра 1942. године у свом чланку с насловом „Георгиосе, нећемо ти дозволити више да радиш шта хоћеш у Турској“335. Чини се да су утицаји нацистичких расистичких идеја, заједно са тешкоћама кроз које је пролазила Турска у економском погледу, учиниле Турке да буду склони дискриминацији према мањинама. Међу овим акцијама против мањима свакако треба навести и случај регрутовања мушкараца немуслиманске вероисповести у мају 1941. године у Цариграду. Циљ Турске владе је вероватно био удаљавање мањина од осетљиве зоне околине Цариграда, али у том тренутку тај потез није био протумачен као расистички чин. Касније наметање пореза varlik није оставило никакве сумње.

У сваком округу Турске, једна комисија државних службеника на чели са начелником (Mahalli takdir komisyonlari) би одређивала висину пореза сваког пореског обвезника понаособ, без права жалбе истог. Закон 4305/1942 је давао за право порезницима да заплене било какву покретну и непокретну имовину пореским обвезницима ако потражени износ не буде плаћен у року од 15 дана од дана објављивања. Законом се сматрају саодговорним за пореску обавезу лица која живе заједно, значи супруга и рођаци. Један месец кашњења је повлачио депортовање у специјалне

334. Закон 4305/1942 о усавајању пореза varlik расправљан је, и изгласан у току само једног заседања грчког Народног сабора (A. Alexandris, The Greek Minority of Istanbul and the Greek-Turkish Relations 1918-1974, A日n்va, 1983, or. 211-229).

335. Alexis Alexandris, The Greek Minority of Istanbul and Greek-Turkish Relations 1918-1974, Center for Asia Minor Studies, Athens, 1983, ог入. 213. Према речима аутора, несумљиво је да је део ове немуслиманске заједнице заиста био неповерљив, јер је покушавао да бескрупулозно искористи тешке тренутке које су сви проживљавали у току рата. 
логоре у централној Малој Азији, где ће дужници обављати принудне радове изградње путева и чишћења снега у замену за отплату њихових дугова.

Пореске листе су објављене на Бадње вече 1942. године. Муслиманима је наметнут симболичан порез, док су немуслиманске мањине биле у обавези да преузму највећи део пореза на имовину. Убрзо је било јасно да је овај порез резултат расне дискриминације, јер су основни критеријуми за одређивање висине пореза били верска и национална припадност пореског обвезника. Седам година након укидања закона варлик, његов извршилац и бивши порезник Цариградског округа (defterdar), Фаик Окте је открио да су се порески обвезници делили на две категорије - на муслимане и не-муслимане Грке, Јермене и Јевреје ${ }^{336}$. Касније су додате још две категорије: страни држављани и Јевреји из Цариграда и Измира који су прихватили муслимаснку веру. Јевреји који су прешли у ислам су плаћали најмање дупло од „правих“ муслимана, док су немуслимани плаћали и до десет пута више. Странци су имали исти третман као и муслимани, са изузетком грчких држављана који су били у обавези да плате сличан порез оном грчке мањине. Такође, Јевреји који су били држављани земаља Сила Осовине нису имали уживали иста права са осталим страним држављанима, што показује немачки утицај у стварању и имплементацији закона варлик ${ }^{337}$.

Грчки амбасадор у Турској Р. Рафаил је, 28. децембра 1942. године, послао телеграм избегличкој влади своје земље у коме је навео да Турска тражи порез за Патријаршију, цркве, школе и наставнички кадар у

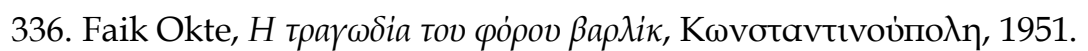

337. Окте пише у уводу своје књиге: „Порез на имовину представља црну мрљу у економској историји наше државе због које треба да се стидимо... Питам се још и данас како нас све нису послали, заједно са премијером владе, пред врховни суд... И шта је остало након свега? Порез на имовину нам је донео 221 милиона лира. То је резултат незакоња и нереда које описујем у овој књизи. Заузврат држава је изгубила веома пуно. Међу најзначајнијим стварима је губитак поверења остатка света према Турској, али и самих њених грађана. Такође, доказали смо да путем пореза држава може, ако то жели,

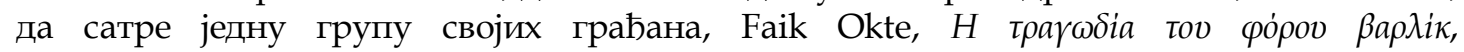

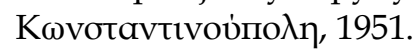


висини од 400.000 турски лира. Нагласио је да ће, услучају да ни исти, ни Грчка влада не буду у могућности да дају овај огроман износ новца, уследити прогони против цркве и школства. На крају је саветовао своје претпостављене да обавесте САД и Велику Британију о овим мерама које су против начела слободе и хришћанства ${ }^{338}$. Одговор који је добила Грчка влада од турског амбасадора у Лондону је био индикативан, и каже да Турска не види разлог противљењу порезу који се односио на све турске држављане, питајући се иронично да ли су у Грчкој влади заборавили да су и грађани грчког порекла такође грађани Турске. Такође је изразио и незадовољство због тога што је Грчка увек прибегавала Патријаршији и користи је као оружје за притисак над турском владом 339 .

Форин офис је задужио амбасадора у Анкари Х. Кначбул-Хугесена да утврди „да ли постоји намера Турске да промени политику пријатељства са Грцима, и ако је то случај, да ли можемо да учинимо нешто да помогнемо ситуацији. Јасно је да не можете учинити ништа што се тиче пореза, и најбоље би било да не чините ништа у вези са архиепископима...“340. Енглески амбасадор је био приморан да их поврати у реалност. Не само да је овај порез био катастрофалан по грчке трговце и да је створио јаз између Грка и Турака, већ је окренуо и грчку заједницу у Турској против Велике Британије које није учинила ништа да помогне. Заиста бројке говоре некад много више него речи. Према званичним подацима Грци, који су представљали 0,55\% становништва Турске, на крају су платили 20\% овог пореза који се наводно наметнуо свим турским држављанима. За порез на доходак, где је муслиман давао 9000 турска лира, Јеврејин је давао 95-500.000 и Грк 105-205.000 лира ${ }^{341}$.

338. Телеграм Рафаила упућен Цудеросу, 28. децембар 1942. (архвіо Tбоoбєрой, фак. 12,

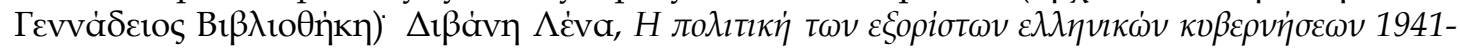

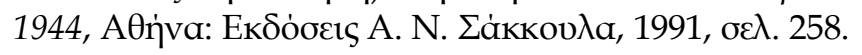

339. F.O. 371/R 5373/1417/19.

340. F.O. 371/37512, R 735.

341. Ради се о запосленима исте фирме са истим приходима. Пример је приказан у табелама А. Александриса у поглављу везаном за начин опорезивања према Varlik 
Од 7. јануара 1943. године почела су да се објављују имена оних који нису платили овај порез, који су касније послани у радничке логоре. У периоду 1943.-1944. године, 1.869 угледних предузетника из Цариграда, припадника мањина, је расељено након што им је имовина била конфискована. У степама у Малој Азији, у логору Ашкале, преминули су од хладноће и тешких услова живота њих 21, од којих су 11 били Грци ${ }^{342}$. Британски амбасадор у Анкари Сер Кначбул-Хугесен је записао: „Нажалост, постоје многи разлози да верујемо да су услови у радничким логорима, у којима живе ти несрећни људи, недостојни сваке савремене цивилизоване државе “343. Истина је да Британија није желела да уради ништа чима би угрозила добре односе са Турском, посебно у време када је Черчил одлазио у Адану у даљем настојању да убеди Турке да уђу у рат на страни савезника. Грчка влада није била обавештена о том састанку, и када је добила прве информације од Рафаела, 29. јануара 1943. године, уплашила се да се спрема завера између Турске и Енглеске против Грчке, у којој би могли изгубити Додеканез 344.

Следеће информације које је добила Грчка дошле су с турске стране. Турски министар иностраних послова Нуман Менеметцоглу рекао је Рафаилу да није дошло до конкретних договора у Адани, али да је постојала сагласност свих страна око улоге коју ће имати Турска у дешавањима после рата на Балкану. Енглеска је умиривала Грке да је теме разговора била помоћ коју би могла да пружи Турска у удаљавању немачких трупа са Балкана ${ }^{345}$. После овога, Грчкој је било јасно да ће равнотежа поморских снага која је уговорена поморским протоколом из

Vergisi у књизи The Greek Minority of Istanbul and Greek-Turkish Relations 1918-1974, Center for Asia Minor Studies, Athens, 1983, oo. 211-233.

342. За имена умрлих види A. Alexandris, The Greek Minority of Istanbul and the Greek-Turkish

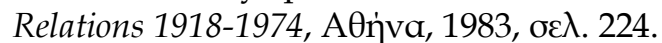

343. Хугенсен (АНкара) према Едену (Лондон), 29.5.1943, F.O. 371/37404/R 5055.

344.Нису били далеко од истине. Детаљније о разговорима у Адани види у поглављу

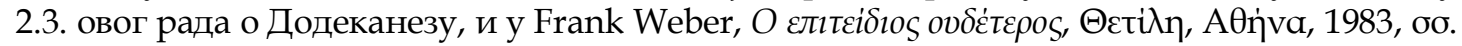

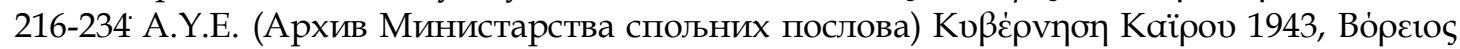

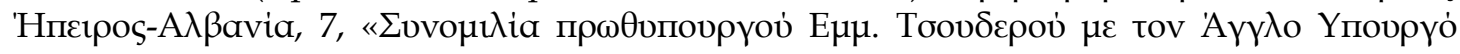

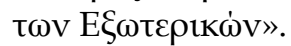

345. Телеграм Рафаила од 2. и 6. фебруара 1943. године (архєіо Тбоvбєрој่, фак. 12,

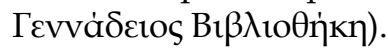


1930. године, који је био део грчко-турског споразума, бити поремећена у корист Турске након што јој је обећана помоћ Велике Британије. Британске службе покушале да умире страсти изјавама да ће Турској бити дати само бродови које је поручила пре рата ${ }^{346}$.

Треба напоменути да је било веома важно за балканску политику Велике Британије да се одржи грчко-турско пријатељство. У неким критичним ситуацијама, међутим, имали су тенденцију да мање рачунају на Грчку, чији је савезништво сматрала у сваком случају обезбеђено. Тако се Лондон, упркос напорима Цудеросове владе за интервенцију Британаца за стављање тачке на овај ванредни порез, ограничио да упути протест само за своје држављане у Турској. Амбасадори како Енглеске, тако и САД-а у Анкари, су се бојали да би притисак на Турску владу због једног „чисто унутрашњег проблема“ довео до тога да се Турска окрене Немачкој. Према оценама Г.Л. Клатона, аналитичара Форин офиса о дешавања у Југоисточној Европи, овакав став савезника „може бити циничан и игнорантан према моралним принципима, али морам признати да је политички исправан“ ${ }^{\prime 347 .}$

Једна од последица овог закона је и непоправљива штета економске позиције Грка у Константинупољу. Према званичним подацима, грчка мањина је морала да плати 80 милиона турских лира од укупног износа од 435 милиона. То значи да је 100.000 Грка из Цариграда, што представља 0,5\% становништва Турске, платило око 20\% укупног пореза варлик. Чак су и социјалне институције грчке заједнице, цркве, школе и болнице опорезоване. Порез на капитал породичних институција се процењује на 400.000 турских лира. Као што је указао грчки амбасадор у Анкари Рафаил Рафаил у разговору са својим енглеским колегом, порез варлик је "брутални напад на грчку мањину у целини, и вођен је политичким, а не економским мотивима“. Такође 
сматра да овај порез има за циљ потпуно економско истребљење Грка у Турској $^{348}$. Са овим ставом се слаже и Форин офис који је веровао у то да су „Турци одлучни да истребе Грке из свог националног живота, независно од тога да ли се ради о мањини са турским држављанством или о грчким грађанима“349. Цудеросова влада је, преко веома активног амбасадора Рафаил Рафаила, наставила да енергично протестује, али покорена Грчка није била у позицији да издејствује нешто боље. Само слабљење моћи Немачке је тада спасило Грке из Цариграда од непосредног нестанка 350 .

Турска је, после неформалног британског интервенисања, потврдила Грчкој влади њихово пријатељство, али је наставила са затварањем радњи свих оних трговаца који нису могли плате огромне порезе и са одузимањем имовине ${ }^{351}$. Благи пад ових акција примећен је почетком марта 1943. године, али је дефинитиван крај овог проблема дошао годину дана касније. Тачније, 15. марта 1943. године, турски парламент је усвојио закон којим се омогућава онима који дугују порез да не плате, и тако је званично, на опште задовољство, укинута ова расистичка мера. Данас је опште признато да је овај порез представљао један од најозбиљнијих кршења Споразума из Лозане о заштити мањина, и показује колико је радикално одступио наследник Ататурка од његове политике добросуседства са Грчком из '30-тих година.

Опортунистичка политика који је следио Исмет Инени током Другог светског рата, и настојања економског истребљења грчке мањине, довели су до престанка искрених билатералних пријатељских односа који су били започели Венизелос и Ататурк у периоду од 1930 - 1931.

348. Детаљи о овом разговору дати су у телеграму Бенета (Анкара) упућеном Ф.О.,

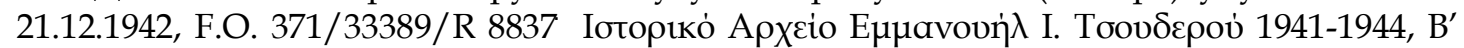

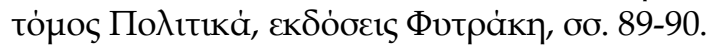

349. Лични телеграм Цудероса (Каиро) упућен Сарацоглуу (Анкара), 3.3.1943, F.O. 371/33389/R 8837.

350. Низом мера од септембра 1943. до марта 1944. године, турска влада је укинула закон варлик.

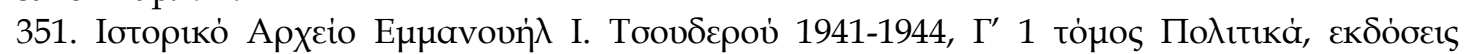

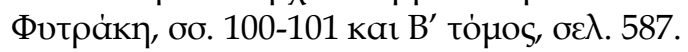


године. Још једном, неповерење и ривалитет карактеришу грчко-турске односе по завршетку Другог светског рата. Под оваквим условима, заказана посета грчког премијера Емануила Цудероса у априлу 1943. године је отказана ${ }^{352}$. Оно што је касније смирило међусобне односе ове две земље, који су били узбуркани дешавањима током рата, била је совјетска опасност која се појављувала на видику, и која је ове проевропски оријенитисане земље довела до НАТО-а.

352. На састанку са Британским министрем спољних послова Сер Ентонијем Иденом за развој грчко-турских односа, Емануил Цудерос је изразио страх од турских амбиција на Егејском мору и нагласио потребу за јачањем грчке морнарице. Детаљи разговора који су се десили 1. марта 1943. године, у Иденовом телеграму (Лондон) за Парлета (Атина), 1.3.1943, F.O. $371 / 37228 /$ R 1873. 


\section{5 ГРЧКА ИЗБЕГЛИЧКА ВЛАДА И АЛБАНСКО ПИТАҢЕ}

Албанија је основана 1913. године након балканских ратова. Рођење нове државе благословиле су две моћне силе у региону, Италија и Аустро-Угарска, са главним циљем да Срби немају приступ Јадранском мору и да та област остане под њиховом контролом. То је био разлог што је грчка војска, која је 1912. године стигла до Авлоне борећи се за ослобођење Северног Епира, била присиљена да напусти те области под италијанском притиском. Границе су утврђене 1913. године од стране Међународног комитета и постале су познате као “Линија Фиренще“ (Florence line) и обухватају део Северног Епира на који је Грчка имала право 353 . Незадовољство Грка из Грчке и из Северног Епира које је изазвао овај договор довело је до формирања „аутономног покрета Северног Епира“ и до крвопролића која су уследила.

У мају 1914. године Северни Епир је успео да кроз разне видове борби оствари тзв. „Крфски протокол“, којим се обезбеђује аутономија школства, цркве и самоуправе двеју територија Северног Епира насељених грчким становништвом. У септембру исте године, у тренутку кад је већ био започео Први светски рат, савезници су понудили Грчкој да окупира Северни Епир, што је Грчка влада и пожурила да уради. Разлог за овакав подухват је био да се заведе ред у тим областима. Штавише, Италија није изгледала да има приговора на тако нешто 354.

У априлу 1915. године, тајним Лондонским уговором (члан 7), Италија је, заједно са осталим савезничким снагама, потписала да нема противљење да подели северну, јужну и источну Албанију са Црном

353. Званичан став Грчке према питању Северног Епира анализира у свом делу $\mathrm{Ph}$. A. Philon, The Question of Northern Epirus, Washington, Greek government office of information, 1945. P. Pipinelis, Europe and the albanian question, Chicago, Argonaut, 1963.

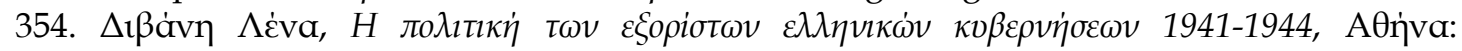

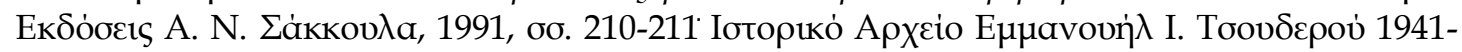

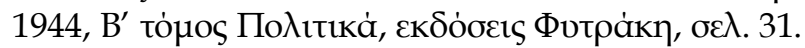


Гором, Србијом и Грчком 355 . Италија је међутим поставила услове за тако нешто, услове који нису били испуњени. Зато је насилно реаговала када је 1916. године Грчка покушала да припоји Северни Епир. У јуну 1917. године Италијански генерал Фереро је прогласио независност читаве Албаније под заштитом Италије.

Две године касније, споразумом Венизелос-Титони, Италија је условно признала грчка права у Северном Епиру. Међутим, овај споразум није никада остварен због катастрофалног пораза које је претрпела грчка војска на малоазијском фронту. Тако су, при финалном одређивању граница између Грчке и Албаније након рата, грчки ставови занемарени. Приликом одређивања грчко-албанске граничне линије, за што је била задужена међународна комисија под командом италијанског генерала Телинија, десио се и изазов Италије на штету Грчке. Убиство Телинија од стране непознатог извршиоца ${ }^{356}$ дало је повод Италији да бомбардује и окупира острво Крф. Овај насилнички чин је био доказ фашистичке равнодушности према новим међународним организацијама које ће бити гарант мира у будућности.

Италија се одлучно наметнула у новонасталој албанској држави преко Ахмеда Зогуа, који преузео власт над Албанијом 1924. Године, и постао краљ 1928. године. Да би уништио своје непријатеље, Зогу је створио савез са муслиманским становништвом на штету хришћана, и окренуо се Италији за помоћ у финансирању војске ${ }^{357}$. Тако је Албанија постала једна врста протектората, где су трговина, превоз, образовање и формирање спољне политике прешле у италијанске руке. У међувремену, грчко хришћанско становништво Северног Епира је постало изложено разним прогонима. Карактеристичан је био случај са грчким школама у региону којих је било преко 200 пре рата, а до 1934.

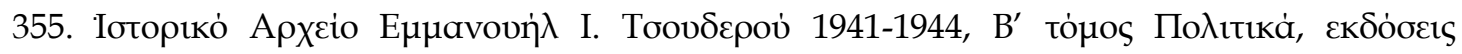

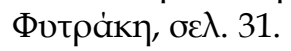

356. О овом подухвату, који је завршен окупацијом Крфа од стране Италије, и који је представљао први пораз Лиге народа, види James Barros, The Corfu incident of 1923, Princeton University Press, 1965.

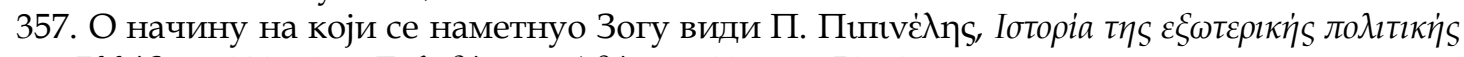

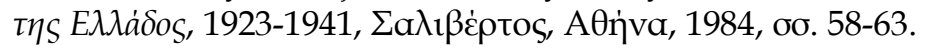


године су потпуно уништене 358 . Из тог разлога је било нужно да 1934. године интервенише Савет Лиге народа, који је стао у одбрану грчких позиција.

Неколико година касније, у априлу 1939. године, Мусолини је окупирао Албанију и претворио је и званично у протекторат. Грчка влада је, страхујући да ће се овај потез на крају окренути против ње, затражила и добила уверења подршке и солидарности од Енглеске и Француске у случају напада. Испоставило се да су страхови Грчке били оправдани јер је, одмах после окупације Албаније, италијаснке трупе почеле су да праве путеве према грчкој граници, где су се касније и стационирале. Пре италијанског напада 28. октобра 1940. године, тензије између две земље су биле подигнуте питањем Северног Епира. Новине „ТОМОРИ“ из Тиране су, 11. августа 1940. године, објавиле чланак који је осуђивао Грчку због убиства „великог албанског патриоте Даут Хоџе“. Том приликом је наведено и насиље од стране Грчке у Цамурији, с циљем истребљења албанског становништва. Италијанска фашистичка штампа је наставила у истом тону извештавања о овом питању 359.

Грчко-италијански рат који је уследио био је свакако непријатно изненађење за Рим. Грчка војска је ушла у Корицу, Агиус Саранда, Аргирокастро и Клисуру. Стара надања о Северном Епиру су опет заживела на кратко, да би опет била разбијена немачким нападима и поразом који је уследио. Чим се Грчка влада нашла у иностранству, побринула се да обавести Велику Британију и друге савезничке земље о својим националним претензијама. Као и у случају Додеканеза, захтев за Северним Епиром је одмах јавно изложен. Ставови Грчке владе у вези са Албанијом виде се у разговорима вођеним између представника Грчке и Југословенске владе 1941. године. У њима Грци не крију очекивања да ће

358. Цудерос је приложио табелу која потрвђује постепено нестајање грчких школа

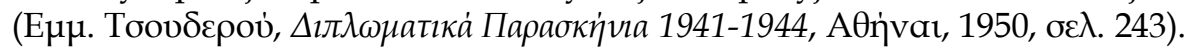

359. Фанатизам и провокаторност ових чланака је потврдио и Е. Граци, италијаснки

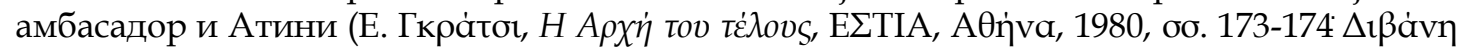

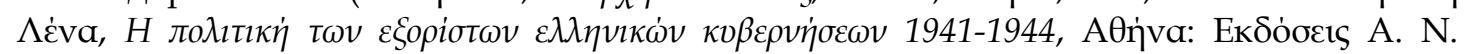

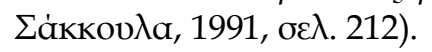


добити територијалне уступке у јужној Албанији. Грци су јавно изјавили да ће затражити од Албаније Северни Епир, Корчу и Аргирокастро. „Ми бисмо тражили ове територије и да није било ратовања на њима, а сад после толико проливене крви с правом тражимо да нам се оне уступе“. Грчка влада сматра да још није време да се питање Северног Епира јавно покрене, али да ће га она одлучно иницирати када за то буде дошао тренутак. Председник Грчке владе, Цудерос говорио је о будућим односима Југославије и Грчке са Албанијом. Тада још увек није могао да створи трајно мишљење о томе како ће Балканска Унија третирати Албанију. Сматрао је да је за тако нешто још рано, али су му две могућности изгледале остварљиве. Прва замисао је да се под утицајем Грчке и Југославије од Албаније направи један привремени протекторат, како би се Албанија потпуно деполитизирала и дефинитивно изузела из досадашње сфере утицаја Италије. Друга замисао је да Албанија буде извесно време окупирана од стране англо-саксонских земаља Велике Британије или Сједињених Америчких Држава. Таква једна привремена окупација Албаније, или боље рећи њено стављање под непосредни утицај Велике Британије или С.А.Д.-а, имала би по Цудеросу несумњиво далекосежне последице - да Албанија буде ослобођена од досадашњег утицаја фашистичке Италије с једне стране, и да, с друге стране, буде материјално и технички унапређена и оспособљена за самостални привредни напредак, да би касније могла ући у Балканску Унију60. Утицај и интерес англо-саксонских земаља над Албанијом имао би и позитивну последицу што би у великој мери умирио албански иредентизам, вештачки разбуђен под утицајем Италије и за циљеве италијанских империјалистичких тежњи над Балканским полуострвом. Такође, само Велика Британија или Сједињене Америчке Државе као моћне, победничке и цивилизаторске силе могле би објективно и са ауторитетом да држе Италију на одстојању и тиме да избегну све

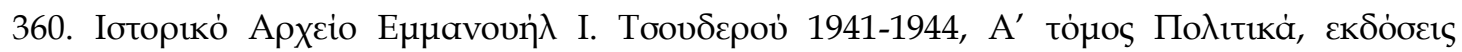

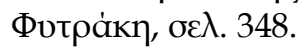


тешкоће и компликације, које би од стране Италије у Албанији могле и даље бити стваране некој другој сили ${ }^{361}$.

Цудерос је, 23. децембра 1941. године, у писму О. Саргенту написао да „када Грци говоре о Северном Епиру и Додеканезу не поставља се питање признавања граница, већ они сматрају да је то грчка територија, као што је признато међународним уговорима, без обзира на то да ли их непријатељске силе, у овом случају Италијани, држе силом већ 20 година. Сада, када је Грчка победила Италијане има право да тражи области које јој припадају и које су биле под италијанском опсадом“362. Британске службе су биле врло добро упознате са грчким ставовима о Северном Епиру, међутим добијали су на времену понављајући познату фразу „након рата о територијалним поделама“. У међувремену, покушавали су да ограниче Грке у јавним изјавама поводом овог питања, као у случају А. Михалопулоса, заменика министра штампе, којем је забрањено да говори о грчком пореклу и традицији области Северног Епира поводом годишњице освајања Корице.

Искрено речено, у периоду крајем 1941. године и почетком 1942. године, нису имали никакав план шта да раде по питању Албаније. Радило се о малој земљи која није била у стању да опстане самостално, тако да је била лак плен за Италијане. Да су Грци тада захтевали јужне области Албаније, према признању премијера избегчичке владе М. Нинчића 363 , и Југославија би захтевала Скадар и друге области северне Албаније насељене Југословенима. У том случају не би много тога преостало 364 . Постојало је мишљење да се решење албанског проблема налази у Балканској унији, идеја о којој се већ увелико расправљало у

361. Архив Србије и Црне Горе (Југославије), 103, Ф 54, бр. 258, Емигрантска Влада К. J. 1941-1945, Албанија 1941 и 103, Ф 56, бр. 267, Емигрантска Влада К. J. 1941-1945, Грчка 1942.

362. F.O. 371/R $10843 / 60 / 19$.

363. Архив Србије и Црне Горе (Југославије), 103, Ф 54, бр. 258, Емигрантска Влада К. J. 1941-1945, Албанија 1941.

364. $\Delta$ «

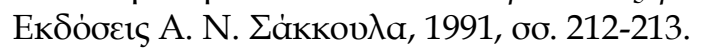


Форин офису. Као део заједнице свих балканских земаља, Албанија би можда могла да опстане у старим, или у новим умањеним границама. Проблем који је отежавао ствари је да Албанија није имала законско заступање у Лондону, нити статус окупиране државе од стране непријатеља. Британци су у разговорима са прогнаним краљем Албаније Зогуом држали безбедно растојање. Он је безуспешно покушавао да се легализује кроз признавање од стране Форин офиса и да образује избегличку владу 365 .

Као што је тачно приметио Цудерос, од јула 1942. године почела су разна дешавања око питања Албаније која су веома забринула Грке. Разлог томе је био предлог SOE-a (Special Operations Executive) да Британска влада направи званичну изјаву подршке за будућу независност Албаније, с циљем да окрену њено становништво против Италијана, јачајући на тај начин албанске устанике. Овај план није спроведен у дело у Форин офису из разлога што „би једини тренутни резултат била подршка будућим плановима SOE-a“. Интересантна је чињеница да је из преписки које се тичу овог питања уочљиво да надлежни у Форин офису сматрају да изјава са оваквим садржајем може да буде дата без великих последица ${ }^{366}$. Вероватно из тог разлога су и били непријатно изненађени због пометњи које су се десиле неколико месеци касније, када су владе САД-а, СССР-а и Велике Британије заједнички одлучиле да треба да јавном изјавом подрже независност Албаније.

У наставку ћемо анализирати детаљније овај развој догађаја. Идену је, 18. новембра 1942. године, упућено посланичко питање на које је одговорио „да Британска влада, у току коначног уговарања мира, о питањима која се тичу Албаније, неће бити подложна било каквом

365. Форин Офис није још поседовао задовољавајуће информације о ситуацији у Албанији и није хтео да се обавезује и отворенно стане на страну Зога. Из тог разлога га је држала на одстојању (F.O. 371, R 1799/867/90 ).

366. У овом случају се поново јавља добро познат андагонизам између политичких и војних служби (F.O. 371/R 4493/867/90). 
утицају који би произашао из италијанске агресије над Албанијом ${ }^{367}$. Дакле, први корак од стране савезника је био признавање чињенице да је Албанија била жртва њихових противника, а није била сама противник. Вредно је спомена да је и након рата Албанија стално тврдила да никада није била учесник у рату. И као доказ за то наводи чињеницу да су њених 6 батаљона који су учествовали у борбама, одмах разоружани и притворени због њихове невољности да се боре 368 .

Британски ратни савет је, 3. децембра 1942. године, одлучио да објави изјаву подршке за независност Албаније, а затим наговорио америчку владу да да изјаву с истим садржајем. Иден је неколико дана касније, тачније 11. децембра 1942. године, упозорио Цудероса да ће се за пет дана Парламент изјаснити и дати изјаву поводом овог питања. У покушају да га умири, рекао је да је упознат са грчким захтевима према Албанији, и да се они уопште не повређују овом изјавом ${ }^{369}$. Грчка влада у Лондону издаје саопштење у којој се наглашава да је Иденова изјава о независности Албаније у складу са основним принципима за које се боре демократски народи против тираније сила Осовине. Такође се истиче, између осталог, да изјава не наговештава коначна решења у вези територијалних питања, као што је питање Северног Епира, за која је влада уверена да ће се решити после рата ${ }^{370}$. Грчки премијер је вероватно реаговао латентно, показавши притом неку врсту губитничког карактера, као што се види из садржаја одговора у писму упућеном Идену. Садржај писма је следећи:

2886/ST/42

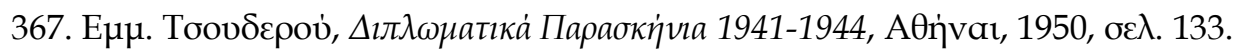

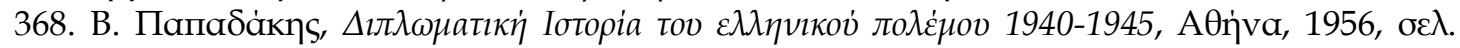
315.

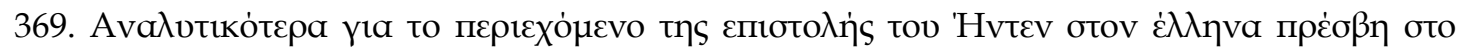

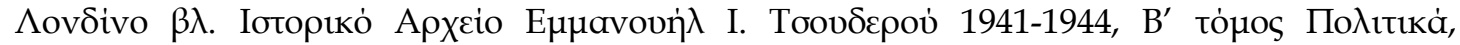

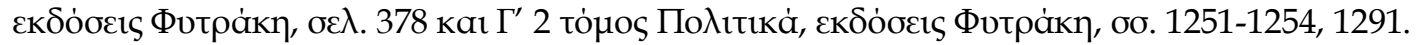

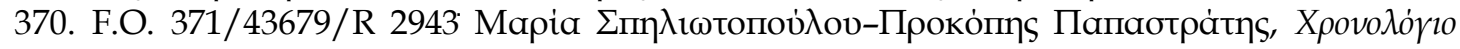

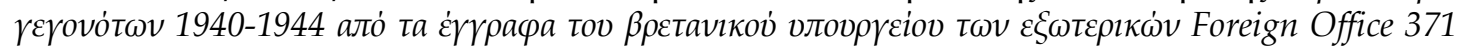

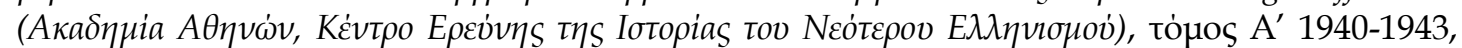

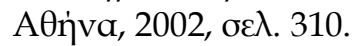


Лондон 14.12.42

Грчки премијер према господину Идену

Објавио сам, као што је била моја дужност, својој влади детаље о садржају вашег поверљивог писма од 11. децембра у вези са одлуком владе Велике Британије да призна независност Албаније. Моја влада је одмах контактирала са пријатељском и савезничком Југословенском владом, у складу са поштовањем Грчко-југословенског споразума од 15. јануара 1942. године, и пошто је размотрено ваше писмо, добио сам наређење да вам саопштим следеће:

1. Узевши у обзир високе идеале због којих су Уједињене нације, и нарочито Грчка, потегли оружје против Осовине, Грчка влада не може имати никакав приговор на одлуку Британске владе која се односи на обнову независности чисто албанских територија. Убеђени смо да је такво разрешавање ситуације праћено и са одговарајућим гаранцијама за витална и легитимна права Грчке.

2. Моја влада је обавештена о вашој одлуци да ће облик владавине и структура владе која ће бити утврђена у Албанији, бити питање о коме ће албански народ одлучивати после рата. Моја влада се слаже са овом одлуком и верује да до краја рата не би требало ниједна Албанска влада, нити било какав албански покрет, да буду званично признати.

3. Са посебним задовољством моја влада је информисана о укидању планиране изјаве у којој се наводи да текст ваше изјаве ни на који начин не прејудицира положај Албаније у односу на будуће споразуме који могу да буду закључени између различитих балканских земаља. Уверени смо да разумете да безбедност Грчке, али и целог Балканског полуострва, зависи од спречавања ванбалканских агресорских снага да поново уђу на албанску територију. Усуђујемо се надати да је ваша изјава прећутно признање посебног интереса за Албанију, који ће из безбедносних разлога, бити признати Грчкој и Југославији. Моја влада чврсто верује да ће то да развије јак осећај заједничких интереса који ће бити за добро свих трију земаља које се 
помињу. Не требамо заборавити да је политика, коју је следила Албанија у прошлости, представљала извор забринутости код балканских држава, а посебно за Грчку. Било би још мање у интересу мира да се питања од општег интереса потпуно препусте на одлучивање Албанији, и да се на тај начин ризикује понављање аномалија из прошлости.

4. Моја влада не може, а да не скрене пажњу британској влади да ће планирана изјава изазвати веома болан утисак грчком јавном мњењу у овом критичном тренутку. Будући да је у страшној патњи под ударом сила Осовине, становништво Грчке неће бити у стању да прихвати мере које ће водити ка независности Албаније, а да се истовремено не признају права Грчке над Северном Епиром. Постоји страх да ће предности, које могу настати у корист Уједињених нација евентуалном сарадњом једног дела албанског народа, бити неутрализоване опадањем интензитета величанственог отпора грчког народа.

5. Питање Северног Епира је од огромног виталног значаја за Грчку, да моја влада не може да не искаже јасно да грчка нација не може да буде део ниједног договора који би запоставио легитимна права Грчке по овом питању.

6. На крају, моја влада ће бити задовољна ако би је Британска влада консултовала пре било какве одлуке која се тиче ове изјаве 371.

Тадашњи председник владе, П. Канелопулос, узбуркао је воде у грчко-британским односима претећи оставком са положаја. Као што је Сарџент написао Кејсију на Блиском истоку, 29. децембра 1942. године, реакција Канелопулоса је била непредвидива. Али и да су је предвидели људи из Британске владе „не мислим да би влада Његовог Величанства

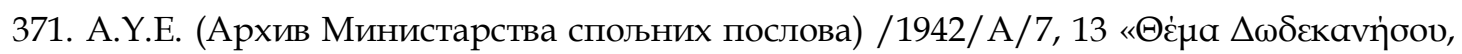

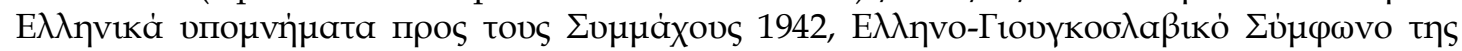
15ns Iavouapiov 1942» Архив Србије и Црне Горе (Југославије), 103, Ф 54, бр. 258,

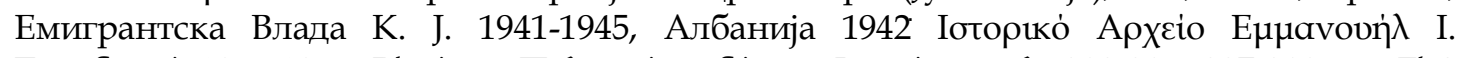

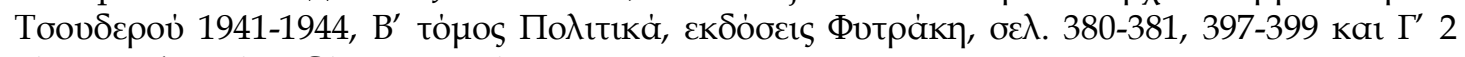

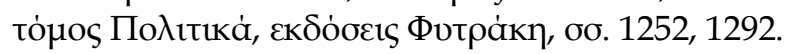


била спремна да промени своје одлуке о Албанији“372. Једино што је успео Канеллопоулос да уради овим потезом је било одлагање изјаве за 24 сата, која је била благо модификована по питању послератног успостављања границе Албаније ${ }^{373}$. У циљу умиривања грчког јавног мњења, Цудеросу је било дозвољено да одржи јавни говор на радију о Северном Епиру, 17. јануара 1943. године. Један приватни разговор који се догодио у том периоду између краља Георгиоса и Идена, у коме је овај последњи обећао Грчкој Северни Епир и Додеканез после рата, никада није потврђен званичном изјавом. Чињеница је да, ако би се грчке територијалне претензије оствариле, то би значило одузимање врло важног и плодног подручја Албаније које чини око 1/4 или 1/5 њене укупне површине, без које би одрживост те државе била под великим знаком питања. Надлежне службе планирања Велике Британије су биле припремиле низ извјештаја почетком 1943. године, нагалшавајући ову чињеницу, као и опасност да се остатак земље распарча или падне у руке неке јаче силе 374 .

У овим извештајима су сматрали да се не би чак ни проблем мањина решио уступањем Северног Епира Грчкој, јер је био толико сложен да ниједно уређивање не би могло да га реши. Једина нада за решавање овог питања, према британским стручњацима, је била сарадња у оквиру Балканске уније и уништавање национализма старијих генерација Грка и Албанаца под перспективом нових послератних визија сарадње два народа. У случају неостваривања Балканске уније, разматрали су могућност да се Албанија стави под међународном контролом и да има статус неутралне земље. Једини захтев који су сматрали логичним је био да се Грчкој додели

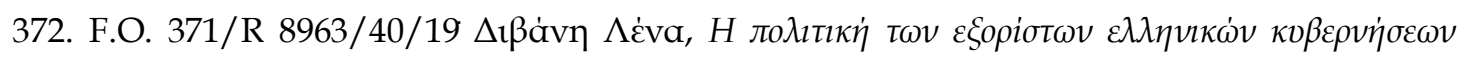

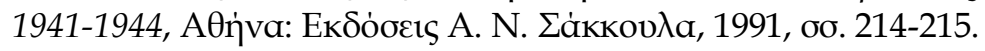

373. O садржају британске и руске изјаве, као и о званичном одговору Грчке види F.O. 371/43569, R 1178 кат R 4346.

374. Ови извештаји, који су сви против грчког захтева, постоје у Ф.О. F.О. 371/37135, R 1753, R 1178 итд. 
континетална област наспрам Крфа, како би сасвим могла да контролише морски теснац 375 .

Резимирајући видимо да су сва британска истраживања ишла у корист Албаније, чињеница коју су надлежни из Форин офиса желели да задрже тајном. Треба напоменути да је након изјаве о независности Албаније примећено велико комешање међу Албанцима у избеглиштву. Постојали су предлози да се образује избегличка влада и да Албанија приступи Уједињеним Нацијама 376.

Форин офис, пошто није имао поуздане информације о албанском јавном мњењу, али претежно зато што је желео да има слободу политичких кретања, није признао ниједну од две фракције прогнаних Албанаца (једна зкоја подржава Зогуа, а друга против њега). Једноставно је покушавао је да држи равнотежу између ове две стране и чекао ${ }^{377 .}$ Исти став су држале и САД. Грчка влада је, у мају и јуну 1943. године, уложила више пута протест Форин офису јер је, према њеним информацијама, забележено насиље албанских герилаца над Грцима из Северног Епира ${ }^{378}$, тачније у региону Аргирокастра, који је био ослобођен од Немаца и контролисан је од стране Комунистичког НОП-а Албаније. Ова организација је погубила многе Грке како би се променио етнолошки састав Северног Епира, и на тај начин не би постојала грчка већина на евентуалном референдуму. У Албанском НОП-у су присутни и хришћани и муслимани. Постоји, штавише, и антикомунистичка, националистичка, албанска организација састављена само од муслимана, која такође врши убијања Грка хришћана (вероватно се овде мисли на организацију Национални фронт - Balli Kombetar). Према информацијама грчки НОП сарађује са оним из Албаније ${ }^{379}$.

375. F.O. $371 / 37135$, R 1753.

376. F.O. 371, R $2127 / 61 / 90$.

377. F.O. 371/37138, R 428.

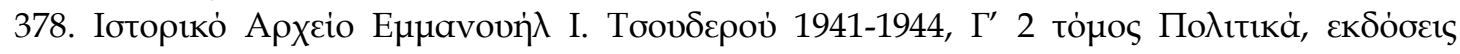

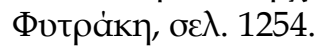

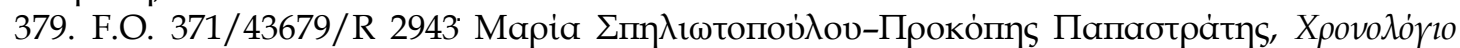

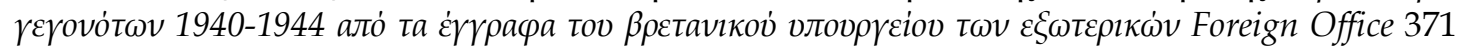


Форин офис је одговорио да не располаже са довољно информација и из тог разлога не може да угуши албанске побуњенике, јер би у том случају могао да буде оптужен за пристрасност према Грцима. Уместо тога, Форин офис је саветовао Грчку владу да ојача атмосферу слоге међу грчким и албанским побуњеницима против заједничког непријатеља. Исту политику једнаких одстојања је упражњавао и СССР по овом питању. Специфичан је начин на који је ова вест пропраћена у медијима која су под њиховом контролом - „У Северном Епиру, где дејствују грчки патриоти, окупатор спаљује многа села и убија ненаоружане цивиле “380.

Став Велике Британије о Северном Епиру се није променио током окупације. У септембру 1944. године, када је било јасно британском политичком и војном вођству да је побуњенички покрет Енвера Хоџе, тзв. ФНЦ, био доминантна сила у Албанији, покушали су заједничким корацима да ускладе своју стратегију новом стању ствари. О. Сарџент је написао у својим белешкама, 26. септембра, 1944. године, следеће : „У случају превременог повлачења немачких снага изгледно је да ће ФНЦ преузети контролу над целом Албанијом, пошто националисти нису у стању да им се супротставе. За очекивати је да ће се комунистичке вође ФНЦ-а окренути према СССР-у, пре него нашој земљи, и шансе да се тако нешто догоди ће се увећати у случају да се после рата створи један словенски блок под совјетским утицајем, који ће укључивати Југославију и Бугарску... Изгледа да не можемо, а да не прихватимо једну владу ФНЦ-а у Албанији после рата“. И поред овога, Британци су покушали да сачувају јак утицај који су имали у Албанији, одлучили су да повуку своју мисију из националиста, да позову Енвер Хоџу на војне разговоре

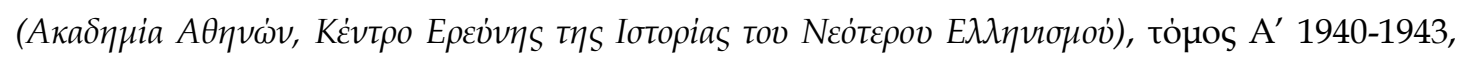

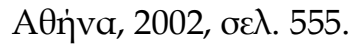

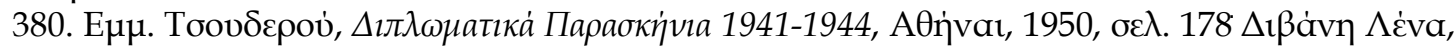

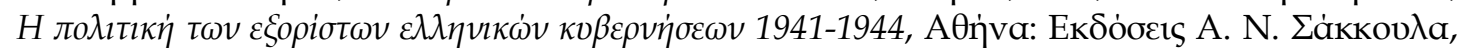
1991, бo. 216-217. 
са Вилсоном, и евентуално након тога да пошаљу једног политичког саветника у владу коју ће оформити Хоџа ${ }^{381}$.

У ишчекивању расплета догађаја Британија није дозволила Грчкој да отвара ову тему пре ослобођења. Навешћемо пример када је, крајем септембра 1944. године, министар пропаганде Г. Карталис говорио на ББЦ-у о Северном Епиру и позивао се на грчки карактер области и права Грчке над њом, добио је снажне критике од Форин офиса, са образложењем да је тај говор засметао Албанцима ${ }^{382}$. Као што је познато, грчке претензије у Северном Епиру нису испуњене после рата.

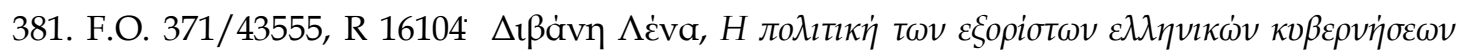

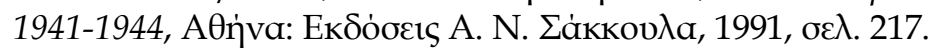
382. F.O. 371/43569, R 16085. 


\section{6 РУМУНИЈА У ПОЛИТИЦИ ГРЧКЕ ВЛАДЕ У ЕМИГРАЦИЈИ}

Грчка према Румунији није имала нека посебна интересовања, будући да је била најудаљенија од свих балканских земаља. Филогермански Антонескуов режим је одвукао земљу у сарадњу са силама Осовине, пресецајући тако везе са савезницима. Британци су сматрали да Румунија припада првенствено совјетској зони утицаја, упркос про-западним осећањима које је гајило ово „латинско острво у словенском мору“. Јасно је било да Совјети траже, у најмању руку, подручје Бесарабије и Јужне Буковине, као и један пријатељски наклоњен режим после рата. Грчка избегличка влада нити је захтевала, нити се надала нечему од Румуније. Чак и у разговорима који су се одвијали у вези са проширењем грчко-југословенског споразума, Румунију су понекад сврставали у Балкански, а понекад у Централноевропски блок.

Када се завршио грчко-италијански рат, тада се отприлике окончао и двадесетогодишњи период спокојства око влашког питања и започео је кратак али буран период дешавања. Влашко питање почиње да се ствара још од 1862. године када је Апостол Маргаритис, Влах насељен у Румунији, дошао у Грчку, у још увек окупиране покрајине од стране Турске, где је почео да врши утицај на многе Влахе, а поготово рођаке Влаха који су се населили у Румунију. Од тада, упркос индиферентности или реаговањима Влаха, који су били фанатични Грци, покрет почиње да добија велике димензије ${ }^{383}$.

Овакав развој је био неминован. У разним заједницама отворене су румунске школе чији најбољи дипломци бивају уписани у гимназијеинтернате у Јањини, Гревени и Солуну где, без трошкова родитеља, добијају диплому о завршеној румунској гимназији. У истим средњим школама се уписују и ученици који заврше грчку основну школу који

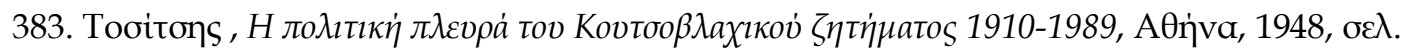


желе да наставе образовање, али немају финансијску могућност за то. Из румунских гимназија-интерната у Грчкој најбољи студенти бивају примљени у Румунији, где студирају бесплатно на разним факултетима у Букурешту. Тако, без икаквих трошкова, најбоља деца сиромашних Влаха живе у Букурешту, где раде као адвокати, лекари, инжењери и јавни чиновници. Међутим, на овај начин велики број младих Влаха одлази из Грчке да живе у Румунију. Тамо, због посебних услова васпитања под којим одрастају, добрих услове живота, али и због лоших услова под којима за разлику од њих живе њихови рођаци у Грчкој, ови „румунизовани“ Влахи постају фанатичне присталице румунског национализма.

Популација од преко 100.000 људи, у великој већини грчког порекла, која је дала Грчкој веома много за време припрема и трајања борбе за независност, као и читавим током слободарског живљења, које је настањено у кључним деловима земље, као што су планина Пиндос, регије Епира и северне Македоније, било је препуштено јаком старном утицају. Услед незаинтересованости од стране грчке државе, код многих Влаха се јавила сумња у вези са њиховом припадношћу грчкој нацији. Природно је појављивање сумње када матерњи језик није грчки, а и Грчка не води никакву посебну политику по том питању, а са друге стране Румунија врши активну пропаганду.

Од првих дана окупације Грчке, у селима Епира, Тесалије и Македоније где се говори влашким језиком запажена је реакција „румунизованих“ Влаха. У овоме нису били сами. Овај покрет створен је од стране домаћих уз подршку Влаха, способних и енергичних кадрова који су имали румунско држављанство. Овај пропагандни подухват је имао ограничене резултате, али свакако не и занемарујуће. Пример за то се могао наћи у једном од влашких села на Пинду, званом Стара Куцуфљани, где је свештеник након недељне литургије у цркви говорио на влашком језику и пожелео здравље вођама Румуније, за које сматра да су прави заштитници села. У селу Вовуса порезник, који је отишао да 
прикупља порезе, добио је одговор да становници неће платити порез зато што нису Грци већ Румуни. У истом селу је било Ђака у румунским школама је, али не и у грчким, из разлога вршења огрмонмог психолошког притиска на мештане који су се осећали Грцима ${ }^{384}$.

Разлози који су првобитно покренули румунске владајуће кругове да иницирају ово питање рекло би се да су емотивне природе. Заиста, изгледа као да се цело питање одликује и претераним емоцијама. Румунски народ почиње да се страсно интересује за једно питање етничког порекла, за које захтевају и жртве, али које нема географских и етнолошких предуслова који могу да претендују на неки стварни интерес, о којем никада није ни било говора. Дакле, док за румунски народ осећања представљају главни узрок стварања влашког питања, за Влахе то није суштина. Ово изузетно сиромашно становништво би, приступајући Румунији, добијало по златну турску лиру месечно, док би деца која су ишла у румунске школе себи обезбеђивала удобан живот током читавог циклуса школовања и универзитетских студија. Према томе, неповољни економски услови су најважнији фактор за претварање мањинског становништва Влаха у фанатичне Румуне, самим тим и стварања влашког питања.

У Румунији је 30. јануара 1941. године забрањено становништву пореклом из Грчке да раде у државним органима, или да буду власници неког предузећа, ако немају уверење од стране неке румунске заједнице у Грчкој, који доказује да су пореклом Власи ${ }^{385}$. Законском уредбом објављеном под бројем 53, од 4. марта 1941. године, у Службеном листу Званичног Гласника Румуније су објављени, под окриљем Министарства економије, акти о поседовању финансијских средстава, права и интереса страних држављана у Румунији, физичких и правних лица, где год да живе или бораве. У складу са овом уредбом, поседовање било какве

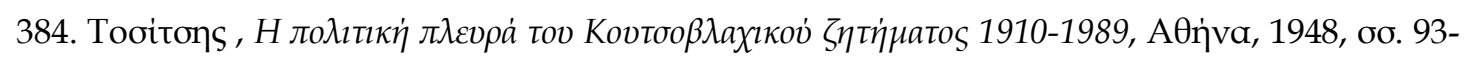
94.

385. А.Ү.Е. (Архив Министарства спољних послова) Графєіо Үфопоорүоن 1936-1941, 1941,

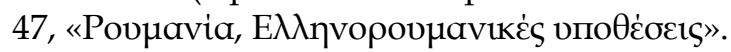


имовине, депозита у банци итд, није дозвољено, осим у случају да тако нешто дозволи одговарајуће министраство уз уплаћивање одређене суме у вредности распродавања стране имовине у Народној банци Румуније. Странци се обавезују чланом 4. ове Уредбе да у року од 10 дана пријаве у Министарству економије поседовање акција, обвезница и хартија од вредности издатих у Румунији. Држављани који бораве ван земље, треба да изврше ову пријаву у амбасадама Румуније земље у којој бораве у року од 20 дана од дана објављивања Уредбе, односно до 24. марта 1941. године. Исту обавезу имају и банке које поседују ову врсту депозита. Према уводном излагању известилаца ове уредбе закона, овај акт представља само једну у низу законских мера које имају за циљ „румунизацију“ економског живота земље. Министарство финансија може, на основу ове Уредбе, да утврди тренутну расположивост ових средстава у Румунији, дајући или негирајући сагласност за њихову употребу. Због немогућности судског одлучивања о овим питањима, министрство финансија може да, без икаквог образложења, да донесе одлуку у корист, или на штету, заинтересованих страна ${ }^{386}$.

У складу са телеграмом Краљевске амбасаде у Букурешту од 11. марта 1941. године, Румунија је објавила законодавну уредбу којом се одређује обавезном добијање дозволе од Министарства поморског саобраћаја за потпуно или делимично преузимање команде над свим превозним средствима која учествују у морском или речном саобраћају, било под румунском или под неком од страних застава, регистрованим у румунском лукама. Ова мера погађа грчке речне бродове на Дунаву 387. Објављена је Уредба, о повлачењу амбасадора Румуније у Атини 4. јануара 1941. године, чији мандат се завршава 15.-ог истог месеца. За даљи наставак рада амбасаде у Атини још није донешена никаква

386. А.Ү.Е. (Архив Министарства спољних послова) Графгіо Ү фопоорүоن่ 1936-1941, 1941,

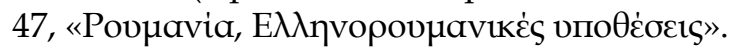

387. А.Ү.Е. (Архив Министарства спољних послова) Графєіо Ү өопоорүоن́ 1936-1941, 1941,

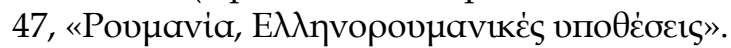


одлука ${ }^{388}$. На иницијативу Румунске владе 25. јуна 1941. године дошло је до прекида дипломатских односа између Грчке и Румуније. Заштита грчких интереса у Румунији за време прекида у односима ће преузети, највероватније, амбасада САД-а у Румунији ${ }^{389}$.

Одлука владе Румуније о прекиду дипломатских односа са Грчком је донета након снажног притиска Немачке. Такође, како извештава генерални секретар Министарства иностраних послова Румуније г. Крециано 16. јула 1941. године, да није претходила одлука Велике Британије којом је прекинула дипломатске односе са Румунијом, Румунска влада никада не би дејствовала за затварање грчке Краљевске амбасаде у Букурешту 390 .

Према извештајима Швајцарске амбасаде у Букурешту, од 13. априла 1942. године, која је штитила грчке интересе у Румунији са великим интересовањем и савешћу, произилазе следеће информације у вези са судбином грчких држављана у Румунији:

- да учестала ограничења личних слобода, притварање у концентрационим логорима, одређиваље обавезујућих места пребивалишта итд., и даље се упражњавају над грчким држављанима;

- да се, у складу са Уредбом објављеном у априлу 1941. године, одбија обнављање радне дозволе Грцима који немају у својим предузећима капитал већи од милион леја, или чији обрт не достиже минимун два милиона леја, или у чијим предузећима није запослено најмање 20 Румуна;

- да је грчком образовном кадру у Галацу наређено да напусте територију Румуније у року од 6 дана;

- $\quad$ да је, у складу са Законодавном уредбом од 10. марта, под називом "reitregire" уведен посебан порез наметнут грчким

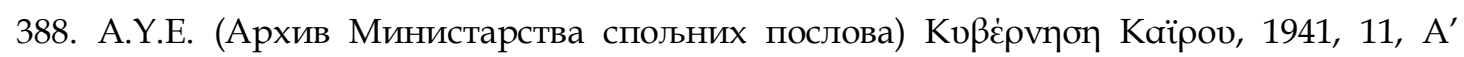

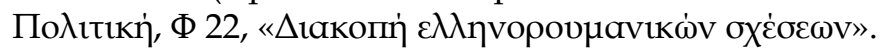

389. А.Ү.Е. (Архив Министарства спољних послова) Коßе́рvұоп Kaїроv, 1941, 11, А'

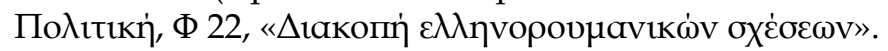

390. А.Ү.Е. (Архив Министарства спољних послова) Коßе́рvпоп Kä̈роv, 1941-1943,

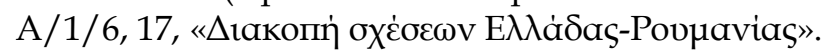


држављанима, а да су од истог ослобођени држављани других земаља, као нпр. Швајцарци;

- да је то предузето одузимање непокретне имовине од Израелаца грчког држављанства ${ }^{391}$.

391. А.Ү.Е. (Архив Министарства спољних послова) Коßв́рvұоп Kаїроv, 1941-1943,

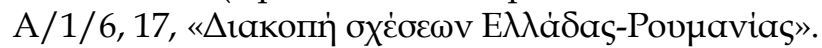




\section{ЧЕТВРТО ПОГЛАВЉЕ}

\section{СИТУАЦИЈА НА БАЛКАНУ КРАЈЕМ И ПОСЛЕ ЗАВРШЕТКА ДРУГОГ СВЕТСКОГ РАТА И ПОВРАТАК ИЗБЕГЛИЧКЕ ГРЧКЕ}

ВЛАДЕ

\section{1 ДИПЛОМАТИЈА ТРИЈУ ВЕЛИКИХ СИЛА}

Почетком 1944. године, наде Британаца да задрже утицај у Грчкој заснивале су се на националној антикомунистичкој влади Емануила Цудероса, која се налазила у прогнанству. Британска спољна политика заснивала се на ограничавање утицаја левичарских партија и заштити њених интереса на источном Средоземљу. Британци су имали два проблема кад је у питању Грчка - да ослободе земљу, протерујући немачке трупе, али истовремено да створе услове за формирање једне репрезентативне владе, која ће моћи да контролише револуционарне снаге и да води државу након повлачења немачке армије.

Стаљин је избегавао било какво мешање у ситуацију у Грчкој, и поред тога што је Черчил држао обавештену Совјетску владу шаљући поруке Молотову. Како је и сам Черчил написао, Совјетска влада се ограничила само на критику британских поступака, и на званичну молбу В. Британије да сарађује у решавању ситуације у Грчкој, упућеној 5. маја 1944. године, одговорила је да СССР не би требало да се на било који начин јавно умеша у дешавањима на политичкој сцени те државе. Черчил је, такође, схватио да ће се британски и совјетски интереси на Балкану сукобити у будућности. Прибојавао се „комунизације“ Балкана, и веровао је да је могућ сукоб са Совјетима због њихове политике у Италији, Југославији и Грчкој392. Знајући да ништа не може спречити долазак ЕАМ-а на власти у Грчкој након немачког повлачења, покушао је

392. Winston Churchill, The Second World War. Triumph and Tragedy, vol. 6, Boston, 1953, pp. 72-73. 
да исправи ситуацију јачањем позиције Британаца у земљи. Генерал Вилсон је сматрао неопходним да се пребаце британске снаге у Атини у року од 48 сати након немачког одласка из града, да би се спречио покушај пуча од стране ЕАМ-а, који је радио на томе у свим крајевима државе 393.

Иден се састао са Фјодором Гусевом, совјетским амбасадором у Лондону, 5. маја 1944. године и предложио му је могућност неког договора у вези са ситуацијом у Грчкој и у Румунији. Две седмице касније, Гусев је саопштио Идену да се Совјетска влада слаже са његовим предлозима и да су Совјети спремни да прихвате договоре, али су саветовали Британце да траже мишљење и од Амераиканаца ${ }^{394}$. Тако је Британска влада, 30. маја 1944. године, послала допис америчком министру спољних послова Корделу Хулу, која је пренета преко њеног амбасадора у Вашингтону, у којему су тражили да сазнају какво је расположење владе САД-а према евентуалном склапању војног уговора Британије са СССР-ом са циљем одређивања утицајних сфера. У том случају, Британија би преузела одговорност за Грчку, а СССР за Румунију. Хул је одбио британску понуду, јер је био против било какве поделе Европе, или њених делова, на утицајне сфере 395.

Черчил је 31. маја 1944. године путем телеграфа, директно затражио од Рузвелта да прихвати понуђено решење, потенцирајући образложење да би такав војни договор био добар корак у виду решавања сваке могуће несугласице између Британије и СССР-а на Балкану. Додао је још да би такав договор представљао природан ток војних дешавања у региону, имајући у виду да је територија Румуније у надлежности совјетске армије, а Грчка у надлежности савезничког

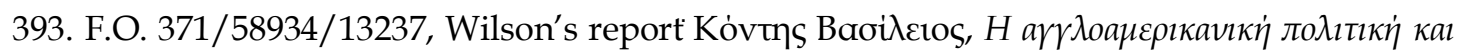

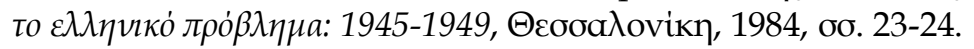

394. Churchill, Triumph and Tragedy, p. 73.

395. Cordell Hull, Memoirs, vol. 2, New York, 1948, p. 1452 U.S. Department of State, Foreign Relations of the United States, 1944, vol. V, Near East and Africa, Washington, 1965, pp. 113114. 
генералштаба у Средоземљу ${ }^{396}$. Черчил је 8. јуна 1944. године, опет послао телеграм Рузвелту обавештавајући га да ће Бугарска припасти под совјетску утицајну сферу, а Југославија под британску, али је истовремено нагласио да његова намера није стварање утицајних сфера на Балкану397. У исто време, Иден је предао Војном савету један меморандум од америчког Форин офиса, у којем се наглашава да би Енглези требало да пораде на стварању власти у Грчкој, која би се после рата окренула ка Великој Британији како би се супроставила совјетском утицају ${ }^{398}$. Несумњива је била чињеница да Британщи нису тражили неко привремено, већ трајно решење.

Могло би се рећи да Совјетски савез, од почетка рата, није био заинтересован за Грчку. Када би и показао неко интересовање, директно или индиректно, то је било само да би извршио притисак на Британску владу, са циљем да обезбеди неку корист у регионима који су јој од већег значаја. Што се тиче Грчке владе у прогнанству, она се понашала као да не представља неку независну државу. Није урадила ни најосновније политичке потезе да би обезбедила корист из овог британско-совјетског ривалства. Напротив, није никад дошла у конкретан контакт са совјетским амбасадама у Лондону и Каиру. У суштини, препустила је Британској влади да буде њен представник.

Чести су били коментари да је америчка политика у вези са Европом била, у општим цртама, политика „из другог плана“399. То значи да су следили британску политику, с обзиром да су Великој Британији признавали превласт у региону. Овакав став не подразумева да никад нису имали несугласице са Британцима. Приговори, које су често имали амерички представници у вези са британским решавањем

396. Department of State, Foreign Relations of the United States, 1944, vol. V, Near East and Africa, Washington, 1965, pp. 113-114 Churchill, Triumph and Tragedy, pp. 73-74.

397. Churchill, Triumph and Tragedy, pp. 74-75.

398. Antony Eden, The Memoirs of Antony Eden: The Reckoning, London, 1965, p. 460 Kóvtns

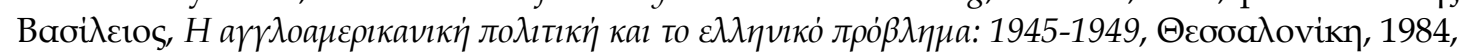
бо. 24-25.

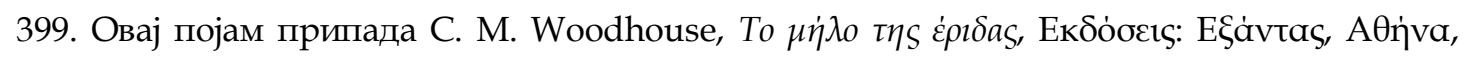
1976, oб. 162-163 
ситуације, били су углавном без суштинског значења јер нису доводили до драстичних промена. Ти приговори су често подривали сумње Енглезима да САД више верују Стаљину него њима. Наравно, ово се односи на дешавања на Балкану.

Осврнућемо се сада детаљније на ситуацију у Грчкој. До Другог светског рата, САД су испољиле врло мало интересовање за дешавања у Грчкој. Дивили су се античкој Грчкој због њене класичне културе, начела демократије и њених филозофа. Ово дивљење је обновљено грчким устанком против Турака 1821. године. Врло важан детаљ који је повезивао два народа били су грчки емигранти који су дошли у САД и створили једну од најзначајнијих мањинских заједница. Након малоазијске катастрофе 1922. године, САД су дали зајам Грчкој за збрињавање избеглица. И са тим се завршавају грчко-амерички односи. Регион је, у сваком случају, традиционално припадао британској утицајној сфери. Америка је само посматрала развој ситуације. Одсуство интересовања потрврђује и чињеница да је амерички амбасадор у Атини Меквиг добио премештај на Исланду. Грчку владу у прогнанству је тада преузео А. Кирк, амбасадор САД-а у Египту, Шведској и Југославији. Кирк је водио дистанцирану политику према прогнаним Грцима. Према брифингу који је урадио свом наследнику Меквигу, његово мишљење је да није тренутак да се враћују на површину стари политички проблеми, и да није прихватао да се сусретне са Грцима који су желели са њим да воде политичке разговоре ${ }^{400}$. Другим речима, САД су се прве две године рата држали далеко било каквог мешања у грчке унутрашње ствари, изузев хуманитарне помоћи коју су дали за прехрањивање становништва ${ }^{401}$. Решавање унутрашњих проблема препустили су Британцима, који су имали вишегодишње искуство на том плану.

Амерички амбасадор Меквиг је покушавао да скрене пажњу председника Рузвелта на Балкан. Нагласио му је да британске радње у

400. Iatrides John, Ambassador Mac Veagh reports: Greece 1933-1947, Princeton University Press, 1980, pp. 388-389.

401. FRUS 1942, vol. Europe, 868.48/2003, 868.51/1654, 868.48/3258. 
многом одступају од оног што су сматрали договореним програмом за свет после рата. По његовом мишљењу, Енглези су тежили ка одржавању „империјалних односа“. Предложио је да САД учествују енергичније у дешавањима на Балкану помагајући обнову држава региона, које ће на тај начин одржавати равнотежу између британског и совјетског утицаја ${ }^{402}$. Рузвелт, међутим, није био расположен да се умеша у балканска дешавања. Већ од конференције у Техерану, на јесен 1943. године, сматрао је узалудно да жртвује животе америчких војника да би одбранио „стварне или умишљене интересе Енглеза у југоисточној Европи“. Закључак је био јасан да нема суштинског мешања на Балкану 403 .

Питање ко ће водити главну реч на Балкану поставило се, по први пут јасно, на пролеће 1944. године. Почетком маја, Черчил је био јако забринут услед „повећаног комунистичког утицаја у Италији, Југославији, Грчкој, Румунији и Бугарској“. Чак је предложио прекид веза са СССР-ом, који је Иден сматрао преурањеним ${ }^{404}$. Иден се, и поред тога, сложио „да је дошло време да сагледамо из дуготрајне перспективе послератне последице ових дешавања, уместо да се ограничавамо, као што радимо сада, на краткотрајну анализу..."405.

И тако је Черчил, већ наредног месеца, преложио СССР-у да поделе утицајне сфере на Балкану, почевши од Румуније, где би главну реч имао СССР, и Грчке, где би предњачила Енглеска. СССР је прихватио предлог под условом да Американци немају ништа против. То је, међутим, представљало проблем, јер никад нису били упитани с тим у вези. Форин офис је 25. маја био принућен да пита владу САД да

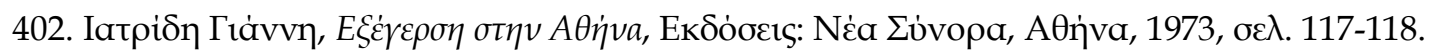
403. Chester Wilmot, «A naïve attempt to end spheres of influence» oto Dallek R. ed., The Roosevelt Diplomacy and World War II, Rinehart and Winston, New York, 1970, p. 72. 404. F.O. 371/43636, R 7380.

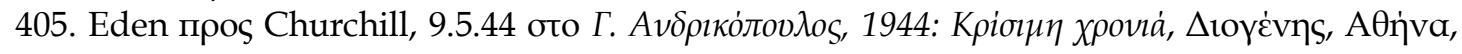
1974, o. 150-151. 
ли се слаже са овим договором, наглашавајући да нема никакве намере за делење Балкана на утицајне сфере ${ }^{406}$.

Хул је био у потпуности против ове идеје, како је и написао у својим мемоарима. Према његовом мишљењу, то би био почетак одступања од проглашених начела политике коју су водили савезници, и начин да се убаци клица неслоге међу њима. У опасност се доводи и целокупан систем заједничке одбране, на који су сви полагали наде ${ }^{407}$. Черчил је одлучио, предвиђајући негативан став Стејт департмента, да се обрати директно председнику Рузвелту. И сам Рузвелт је био разочаран ставом Енглеза, јер да није у међувремену информисан да Совјети траже његову сагласност, не би ни сазнао за овај договор 408 . Черчил се нашао у тешкој позицији. СССР су настављао неометан своје акције на Балкану, а Американци су, по његовом мишљењу, одбијали да помогну у тој ситуацији. Када је Липер затражио од америчког амбасадора Меквига да подржи Папандреуа, он је одбио наглашавајући да политика САД-а није подршка једне странке или једне личности, већ да се постигне слога у региону 409 .

Након Рузвелтовог одбијања да прихвати утицајне сфере, Черчил je 11. јуна 1944. године, на још убедљивији начин покушао да покрене ову тему. Објаснио је Рузвелту да је ситуација у региону опасна: „Ситуација се мења муњевито и неконтролисано у овом региону Балкана. Неко мора да поседује моћ да одлучује и да делује... Кад би започела нека врста тростране или четворостране комуникације, једини резултат тога био би хаос и неделовање 410 . На крају му је предложио

406. F.O. 371/43636, R 7903.

407. Cordell Hull, Memoirs of Cordell Hull, Hodder and Stoughton, London, 1948, Vol. I-II, oб. 1451-1452. 408. F.O. 371/43636, R 10039.

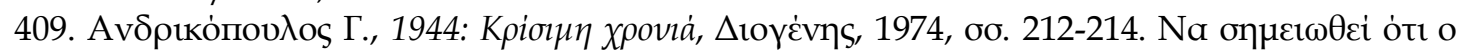

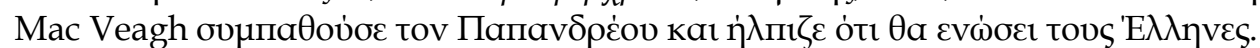

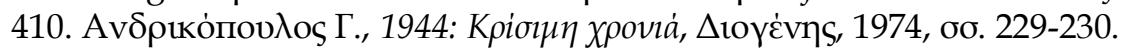


пробни период од три месеца, који је Рузвелт прихватио без саветовања са Министраством спољних послова ${ }^{411}$.

Када је истекао тромесечни пробни период за утицајне сфере, Черчилу је био потребно продужење договора. Састанак Черчила и Стаљина одржан је у Москви, док Рузвелт није могао да присуствује због избора. Резултат овог састанка је било продужење договора о утицајним сферама, али овог пута је договорено решење за читав Балкан, а не само за Грчку и Румунију. Према чувеном, и јако оспораваном, парчету папира који је написао Черчил, а који је одобрио Стаљин, 90\% утицаја у Грчкој се признаје Британији ${ }^{412}$. Заиста, два дана након споразума, 11. октобра 1944. године, Молотов је са задовољством објавио Грчкој влади да је његова влада дала упуства Бугарској да у што пријем року напусте грчку територију. Повлачење је започело већ следећег дана, чињеница која је натерала Папандреуа да се топло захвали Черчилу и Идену за договоре које су склопили у Москви ${ }^{413}$.

Кад је Меквиг обавештен о премештају прогнане Грчке владе у Италију, одбио је да је прати. Исто су урадили и остале дипломате, осим Липера. Меквиг је сматрао да би његово путовање за Италију представљало „знак сарадње са Британцима у случају мешања у грчке унутрашње послове, нешто што је јасно да у том тренутку не постоји. Меквиг је рекао о томе: „Не чуди ме што је Липер оценио неопходним моје присуство у Италији. Неопходно је било да би он ојачао своју позицију америчким одобравањем. Али ја сматрам да је такође неопходно да држимо наше руке чисте, и не учествујемо у овом великом

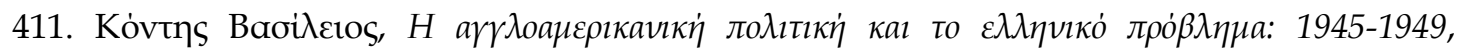

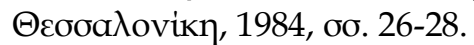

412. Овај договор је оспораван до скора од стране совјетских историчара јер сматрају да је то само производ маште импреијалиста. Суштина ствари је, невезано да ли се споразум десио стварно или није онако како га је Черчил описао у својим мемоарима, имала је као резултат слободу Британаца да управљају грчким проблемима. Детаљније о овој теми погледај чланак Stephen Xydis, «The Secret Anglo-Soviet Agreement on the Balkans of October 9, 1944», Journal of Central European Affairs, Vol. 15, Oct. 1995, pp. 248271.

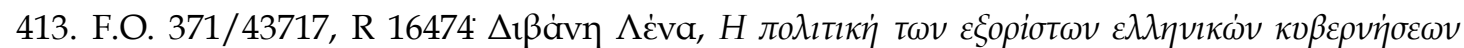

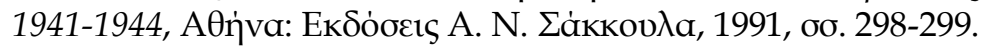


интервенисању које је претворило Папандреуа у премијера-марионету, и одузело му право да да оставку када је хтео, и којега премештају заједно са остатком владе по читавом свету према Черчиловим наређењима“414.

Исти став према Грчкој исказује и Рузвелт, који и поред тога што је одобрио и помогао мисију британских војника у Грчкој, није могао да се препозна у потпуности са Черчиовом политиком. Његова политичка догма је била „да ослободимо окупиране земље, па да их онда пустимо да изаберу саме на који начин желе да буду вођене“415.

Америчка политика према Грчкој у току Другог светског рата, у кратким цртама, била је признавање чињенице да Велика Британија традиционално води главну реч у региону Балкана и подршка, посебно од стране Рузвелта, британском плану за Грчку кад је то било могуће, држећи у сваком случају неоходну дистанцу, да не би испало да две државе воде заједничку политику, и самим тим да имају исту одговорност. Ову уздржаност је одржавао посебно Стејт Дипартмент, имајући на уму да би скандалозно мешање Британије, са циљем наметања Краља народу који га не жели, окренуло на крају Грчку ка Москви ${ }^{416}$.

На крају се морамо осврнути на још један значајан чинилац који је одиграо улогу у британским и америчким одлукама о Грчкој и Балкану. САД су почеле да показују интересовање за регион у току рата, када је кренула велика потражња за нафтом. Водећи кругови у САД су били забринути јер нису поседовали велике залихе. Само 15\% од светских залиха се налазило у САД. Стејт Дипартмент је знао да нафта представља стратешки веома битан извор моћи. Иако су постојали наговештаји о улози коју ће играти Британија по овом питању, а коју је она традиционално контролисала, две државе су се сложиле да потпишу, 8. августа 1944. године, договор који је представљао њихове напоре да

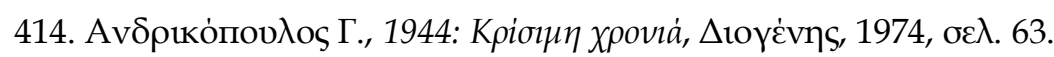

415. Pirjevec J., «The roots of British, American and Yugoslav Policy towards Greece in 1944», Journal of the Hellenic Diaspora, Fall, 1984, Vol. XI, No 3, pp. 81-87.

416. F.O. 371/43692, R 14265. 
уведу ред у дешавањима са нафтом. САД су од тада почеле да схватају боље британску политику искоришћавања Грчке, Турске и Ирана као бране против руског уласка на Блиском Истоку. Немир који је Стејт Дипартмент имао због британских поступака према Краљу Георгију II, које иду у крајњост, заснивао се на страху окретања расрђених Грка према СССР-у. Као што је Меквиг једном рекао: „Британија и САД ће на дуге стазе изгубити, када СССР буде наследила Средњи и Блиски Исток“417.

417. Повезивање грчког проблема са нафтом поменуто је у књизи Lawrence Wittner, American Intervention in Greece 1943-1949: A Study in Counterrevolution, Columbia University Press, New York, 1982, pp. 17-22. 


\section{2 ЦУДЕРОСОВО ГЛЕДИШТЕ НА ПОЛИТИЧКИ СИСТЕМ ГРЧКЕ ПОСЛЕ ДРУГОГ СВЕТСКОГ РАТА}

Друштвено мњење Грчке, која је само новембра 1944. године била већином демократска, изгледа да се окреће ка супротној страни из два разлога, чији је исход још под знаком питања. Први је паника коју су изазвала дешавања из децембра 1944. године и револт народа против КПГ који је уследио. Други чинилац су велика обећања којима поборници краљевског режима обасипају народ у вези са последицама које ће уследити непосредно након повратка Краља у Грчку. Мислило се да ће Краљ сам, на неки магичан начин, завести ред у држави и решити све проблеме - националне, економске, класне.

„Јасно је колико је нестабилно једно такво друштвено мњење, које се на овако важној одлуци не ослања на уверењима већ на чиниоцима, који ће се у наставку показати као неосновани и неистинити. Разочарење, које ће уследити од овог тренутка па надаље, довешће до врло брзог преокрета у јавном мњењу. У овоме ће помоћи и следећа два чиниоца, који су постојани и непромењиви. Први чинилац је грчка омладина, која тражи напредак кроз демократију. Недостаје јој само вођство којему ће дати своје поверење. Већина грчке омладине је за брзи напредак, за остварење идеја које ће довести до друштвене праведности и слободе, не само појединаца, већ и њихових заједничких интереса. Свесни су чињенице да насиље рађа насиље, и да се режими силе не могу дуго одржати. Други чинилац је глобални заокрет ка новим политикама и савременим политичким правцима. Земље које не увиде на време ове промене, и не промовишу их одмах са правним одлукама, осуђене су на народне буне. Грчки народ поседује веома снажне политичке рецепторе, тако да ће сам изабрати прави пут“418.

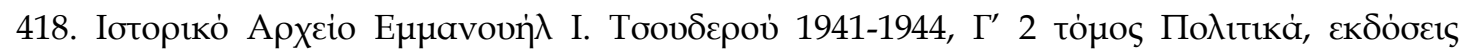

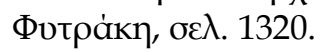


На основу ових претпоставки и размишљања, Цудерос не може да поверује да је одржива идеја о утврђивању краљевског режима, за који ће и један део друштва гласати са надом да ће Краљ владати као демократски владар. „Не смемо заборавити да већ тридесет година постоји грађански рат унутар саме Грчке по питању режима власти. Ова борба, која за добробит земље мора бити окончана што пре, створила је чврсте темеље за демократију, коју данас помажу и активности омладине“".

„У случају да Краљевина поново дође на власт путем референдума, који би био резултат претходно наведених психолошких чинилаца, сусрела би се са снажном политичком реакцијом. Резултат референдума ће бити испоштован, али то не ограничава да се у будућности нове идеје остваре кроз политичку борбу. Ако Краљевина испоштује слободу говора, као што је дужна да уради, тада ће промена доћи без употребе силе. Ако, међутим, Краљевина по други пут покуша да се успротиви овим новим тежњама и народним слободама, неизбежно ће доћи опет у ситуацију да заведе диктатуру. Диктатуру већ од сада жељно прижељкују политичке и војничке групације или појединци који, јавно или прикривено, раде на повратку Краља. Међутим, диктатура ће изазвати револуцију, јер је грчки народ против диктатуре, као и јавна мњења савезничких народа, који су ратовали против диктаторских режима. У овим условима, нова краљева диктатура ће бити свргнута путем силе“.

Овакав могући расплет догађаја не иде у прилог чињеници да ће повратак Краља бити осигурање за ред у земљи. За питање политичког режима потребно је наћи решење које гарантује што дужи период стабилности. Врло је вероватно да ће и Председничка демократија наићи на препреке и потешкоће, па чак и аномалије, услед послератног стања ствари. Биће, међутим, лакше за земљу да их савладава и превазиђе, 
услед еластичности коју ће имати захваљујући избору Врховног вође, сваке четири године ${ }^{419}$.

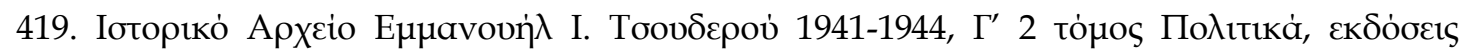

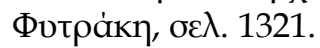




\section{3 ПОВРАТАК ГРЧКЕ ЕМИГРАНТСКЕ ВЛАДЕ И УРЕЪЕЊЕ ПОЛИТИЧКОГ СИСТЕМА - ПРОБЛЕМ ОДНОСА СА ПОКРЕТОМ ОТПОРА ЕАМ-ЕЛАС}

Од 1941. године, па све до ослобођења Грчке од сила Осовине у октобру 1944. године, држава је имала две владе - „Атинску владу“, коју је признавала Немачка и њени савезници, и емигрантску владу, коју су признавале земље које су се бориле против Осовине. Емигрантска влада је репрезентовала Грчку у новоформираној Ораганизацији Уједињених Нација, и тако представљала званичну и легалну владу грчке државе. „Атинска влада“, или познатија као „окупациона влада“, није поседовала народни легитимитет који произилази из слободног избора од стране народа, већ је била наметнута од стране окупатора. Али и поред тога, ова влада је представљала власт унутар државе. Влада у прогнанству, иако није вршила званичну власт јер се налазила ван граница Грчке и њене активности нису биле признаване од стране Атинске владе, је добијала свој легитимитет од највишег органа власти у земљи, од Краља Георгиоса II, као и признавањем од стране влада земаља које су ратовале против Осовине.

Немачке, италијанске и бугарске окупаторске трупе су, након инвазије у Грчку, немилосрдно пљачкале земљу и нису бринуле о расподели помоћи локалном становништву.Услед британске изолације, која је прекинула увоз хране, појавила се глад у периоду зиме 1941-42. године. Иако се ситуација полако поправљала присуством Међународног Црвеног крста, основне намирнице су биле и остале врло ретке за већину становништва, готово све до завршетка окупације. Влада је изгубила потпуно на угледу јер је била принућена да сарађује са окупационим властима, остајући тако без моћи и материјалних средстава. Традиционални лидери друштва, политичари и војна елита, закаснили су са организацијом било каквог облика социјалног старања и отпора окупатору. 
У овим условима створила се празнина у власти, коју је постепено покривао Народно-Ослободилачки Фронт (ЕАМ). Он је формиран већ првих недеља окупације од стране језгара комунистичке партије, који су били састављени од неколико стотина чланова који су успели да побегну из затвора и са острва на којима су били прогнани у периоду владавине Метаксаса ${ }^{420}$. Првобитне јединице социјалног старања ЕАМ-а претвориле су се у савез мешовитих организација, које су се заснивале на масовном учешћу и покривале су потребе становништва, колико је то било у њиховој моћи.

Врхунац овог покрета представљала је привремена „планинска влада“, која је формирана марта 1944. године. Трећа врста власти, нека врста „владе из сенке“, био је Политички Комитет Народног Ослобођења (ПЕЕА), који је оформио Народно-Ослободилачки Фронт (ЕАМ) 1944. године у планинским пределима централне Грчке. Ове пределе је од јесени 1943. године контролисала Грчка Народно-ослободилачка Војска (ЕЛАС). Иако је званично била демократска, и тиме ширила ентузијазам у народу, ЕАМ је вођен у тајности од стране комунистичке партије, која је постављала људе на водећим местима и прожимала се кроз читав покрет својим неумољивим духом. Помоћу своје побуњеничке војске и терором својих локалних вођа, ЕАМ је приморао већину рецолуционарних група да се им се припоје или ће бити сматрани за непријатеља. У периоду 1943-44. године било је скоро извесно да ће власт преузети ЕАМ када Немци напусте земљу ${ }^{421}$. Политички Комитет Народног Ослобођења, као и влада у прогнанству, били су непријатељски настројени према Атинској влади. ПЕЕА је са емигрантском владом имао ривалски однос, тако да је покушао да јој наруши углед у очима грчког народа. Директни циљеви ПЕЕА-а били су да организује и да управља народном борбом за ослобођење, да врши власт у већ ослобођеним областима, и да обезбеди превласт у народу

420.

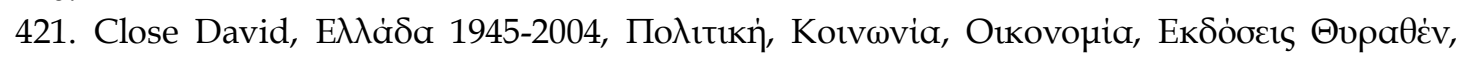

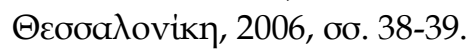


дуж читаве земље ${ }^{422}$. Упркос томе, ни ПЕЕА, ни Атинска влада нису покушале да оспоре међународну репрезентацију Грчке од стране владе у прогнанству ${ }^{423}$.

Емигрантска влада је прогласила основни циљ, а то је вођење рата против Осовине на страни Велике Британије и осталих савезника. Грчка влада је ставила на располагање савезничкој борби против Осовине јединице ратне морнарице, које су пребегле у априлу 1941. године у Египту, као и копнене јединице које су тамо састављене од пребеглих грчких официра и добровољаца. Допринос ових снага у току рата био је значајан, што је признато је од стране савезника. Учешће Грчке владе у рату, са свим расположивим снагама, био је резултат вере Краља Георгиоса II и чланове владе у праведну борбу против фашистичких снага, у ослобођење Грчке, и остварење њених националних амбиција. Вредно помена у савезничкој борби било је и учешће револуционарних организација унутар окупиране Грчке, посебно ЕАМ-а и ЕДЕС-а (Грчки Демократски и Национални Савез), које су изводиле диверзије, уз помоћ британских тајних агената, и изненадне нападе против окупационих снага Осовине. Британска влада је потпомагала политички, економски и војно ове револуционарне организације. У њиховим војним штабовима постојали су чланови британске војне мисије, који су требало да координирају акцијама револуционарних снага да би се на најбољи начин подржавали војни циљеви савезника током рата. Британска помоћ ЕЛАС-у, који је био војни огранак ЕАМ-а, смањио се од јесени 1943. године. Тада је ЕЛАС отпочео организоване нападе против ЕДЕС-а и против осталих револуционарних организација које су се противиле потчињавању ЕЛАС-у, из разлога што је ову организацију контролисала, преко ЕАМ-а, Комунистичка Партија Грчке ${ }^{424}$.

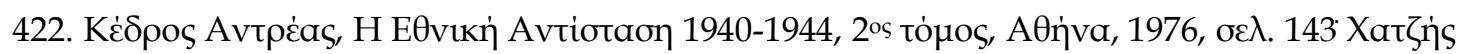

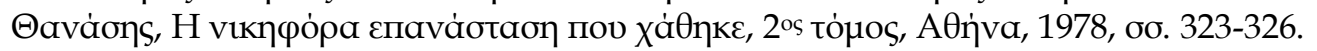

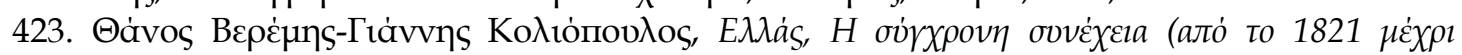

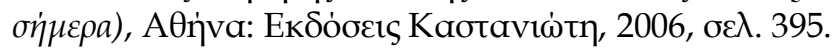

424. Richard Clogg, British Policy towards Wartime Resistance in Yugoslavia and Greece, London: Macmillan, 1975, pp. 117, 147, 167. 
Још једна ствар са којом се нису слагале Британска влада и ЕАМ, било је питање будућег државног уређења Грчке. ЕАM је потенцирао да Краљ Георгиос II не треба да се врати у Грчку. Најзначајнији аргуметни за тако нешто били су да се вратио у земљу 1935. године без слободно изражене воље грчког народа, и да се сложио са увођењем диктатуре Метаксаса, и прихватао протеривања политичких неистомишљеника. Такође, већина грчког народа није желела његов повратак пре спровођења новог референдума око државног уређења. Ка ставовима ЕАМ-а тежио је и већи део политичара, присталица Венизелоса ${ }^{425}$. На другој страни, ка ставовима Британске и Грчке владе тежио је један део Венизелосових противника. Што се тиче друштвеног мњења у окупираној Грчкој пре ослобођења, ЕАМ је сматрао да је расположење у народу под знаком питања, јер није постојала могућност слободног изражавања мишљења, како у окупираним, тако и у деловима земље под вођством ЕАМ-а ${ }^{426}$.

С друге стране, Британска и Грчка влада су сматрале да је Георгиос II, који се показао као снажна и значајна карика између ове две државе у тешким и трагичним данима капитулације Грчке и након тога наставио да буде гаранција за промоцију грчких националних интереса, потребан за постепену обнову политичког живота који је био разрушен скоро читаву деценију. Званична британска политика према Грчкој била је да подржава повратак Краља након ослобођења. Разлог за то био је тај да Форин Офис је сматрао да би Уставна краљевина представљала најбољу гаранцију да ће послератна Грчка бити пријатељски наклоњена Британији. То је било у складу са најбитнијим британским амбицијама у региону, имајући у обзир да Грчка заузима веома значајно стратешко место за британски поморски саобраћај и пут ка Блиском истоку, одакле се снабдевала преко потребном нафтом. Једним делом, британска

425.

426. Погл. Procopis Papastratis, British Policy towards Greece during the Second World War 1941-

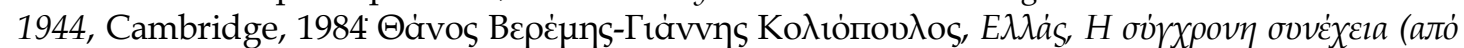

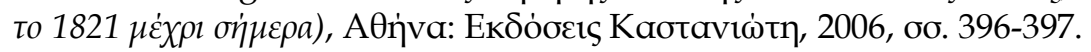


подршка монархији била је и једна врста Черчилове личне обавезе према Краљу Георгиосу II за његово храбро деловање током првих критичних месеци 1941. године. Све чињенице и информације које су долазиле из Грчке показивале су огроман пораст демократског расположења, ствар која је наговештавала озбиљне проблеме за британске политичаре ${ }^{427}$.

Ослобођење Грчке у октобру 1944. године, након повлачења немачких и бугарских окупаторских трупа, које је било пре завршетка рата резултирало је поновним стицајем независности и територијалног интегритета, али није гарантовало остале националне претензије, као што су припојавање Додеканеза и Северног Епира, и разграничавање на грчко-бугарској граници. Позитиван расплет ових претензија отежавали су неки догађаји, као што је рушење фашистичке владе у Италији и њено капитулирање на иницијативу нове владе 18. септембра, и рушење пронемачке владе у Бугарској у септембру 1944. године и преузимање власти од стране левичарског фронта. Фронт је имао подршку совјетске Црвене армије, која је ушла у северноисточну Европу у том периоду. Италија, као и Бугарска, непријатељске земље до тог тренутка, постале су пријатељске, имајући и подршку од стране јаких земаља које су се бориле против Осовине. Сличну подршку уживала је и још један доскорашњи непријатељ, Албанија, чија се нова влада такође сврстала уз раме победичким снагама.

Иницијативе Грчке владе, која се вратила у Атину одмах након повлачења немачких окупационих трупа у октобру 1944. године, отежавало је погоршавање политичке ситуације унутар земље, као и отворени сукоб у Атини, у децембру 1944. године, између војних снага које је послала Британија и малобројних снага којима је располагала Грчка влада са ЕЛАС-ом. Тај сукоб је изазван одбијањем ЕЛАС-а да разоружа своје јединице, како је било договорено на састанку представника револуционарних организација, Грчке владе и Британског

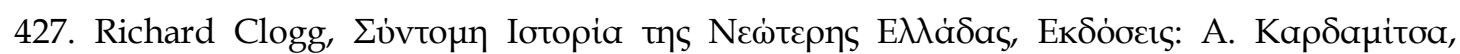

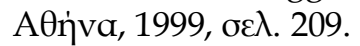


генералштаба за Блиски исток, који је одржан претходног септембра у Казерти у Италији. Постојали су многи разлози који су довели до првих сукоба између две стране и до њиховог ширења, без покушаја са ниједне стране да се избегне општи оружани сукоб ${ }^{428}$. Ти разлози су били: узајамне сумње између две стране, EAM-a и владе Георгиоса Папандреуа, понашање комунистичке елите ЕЛАС-а у контактима са владом, недостатак јасних политичких ставова од стране комунистичког вођства услед неслагања унутар саме партије у вези директних циљева КПГ, подршка вођству комунистичке партије од стране комунистичких вођа Југославије и Бугарске да покуша да преузме власт оружаним путем, насупрот нејасних одговора који су долазили од врховне власти Совјетског савеза, као и одлука влада Грчке и Британије да не поклекну под притиском и уценом вођства ЕАМ-а, који је захтевао већи део удела у власти.

Исход сукоба је углавном одлучен на бојном пољу. Снаге које је имала на располагању ЕЛАС у атинском сукобу, иако многобројније, биле су слабије по ратној вредности од британских. ЕЛАС је била устаничка војска састављена углавном од необучених младих сељака, способних за сукобе са локалном полицијом или са побуњеницима противничких револуционарних организација, али није била спремна за сукоб са дисциплинованим јединицама редовне војске. ЕЛАС је поражена јер је њено комунистичко вођство одлучило да је одведе у један сукоб који јој није био прикладан, и за који није била довољно спремна. Комунистичке снаге, сада већ протеране из главног града, су се

428. Док вођство КПГ не да ваљане доказе који би оповргли ово, чињенице које су на располагању са обе стране подржавају мишљење које су имали противници EAM-а, а то је да КПГ, преко ЕЛАС-а, покушавала да преузме грчку престоницу. Могуће је још претпоставити да је одсуство прецизних политичких циљева, у комбинацији са лакоћом којом је комунистичко вођство започело оружани сукоб, показивало њену намеру да примора своје противнике, путем оружја, да преговарају са EAM-ом из инфериорнијег положаја (John O. Iatrides, Revolt in Athens. The Greek Communist "Second Round" 1944-1945, Princeton: Princeton University Press, 1972. Enions $\beta \lambda$. To $\mu \varepsilon t a \gamma \varepsilon v \varepsilon \dot{\sigma \tau \varepsilon \rho o ~}$

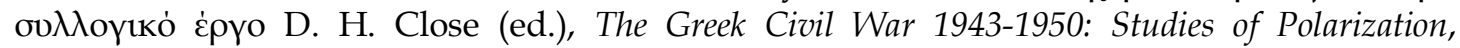

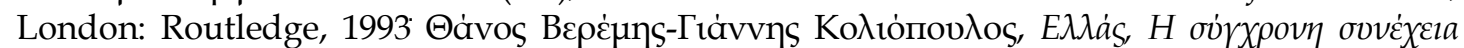

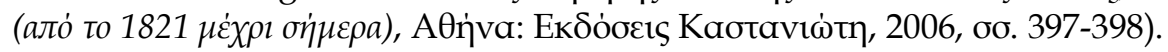


нашле очи у очи са стварношћу. Преживљавање становништва зависило је од британске помоћи, док су остале левичарске странке препустиле КПГ својој судбини. У фебруару су ове снаге биле принуђене да се предају представницима Британаца према Договору из Варкизе, и да растуре своје војске. За узврат, Британци су обећали да дају амнестију за политичке прекршаје, слободне изборе, и политичке слободе које нису могли, нити су хтели да наметну. Договор из Варкизе је потврдио да Грчка припада западној капиталистичкој утицајној сфери Европе, а не совјетској комунистичкој.

Вођство КПГ није било упознато са чувеним Уговором о процентима из 1944. године, који су постигли председник Британије Винстон Черчил и генреални секретар КПСС Јосиф Стаљин у Москви. По том уговору Британија допушта Совјетском савезу да има превасходни утицај у земљама Источне и Југоисточне Европе, изузев Грчке, у којој ће главни утицај имати Британија са блогословом Совјетског савеза ${ }^{429}$. Овај договор је био циничан, али у исто време реалистичан, и показивао је, не само тежње два савезника, већ и војну и политичку ситуацију у региону након уласка јаких снага Црвене армије у Источној и Југоисточној Европи, и присуства британских снага у Италији и Грчкој. Руководство КПГ није познавало уговор из Москве. Међутим, могло је да прида већи значај чињеници да су јединице Црвене армије, које су ушле у Бугарску, нису ушле на територију Грчке ${ }^{430}$.

Споразумом у Варкизи, 12. фебруара 1945. године, завршени су и званично сукоби у Атини, „Децембарски догађаји“, како су названи јаки сукоби за превласт грчког главног града. Тај споразум, међутим, није решавао политички проблем у Грчкој. КПГ је у почетку била преузела на себе покушај да уцени владу да прихвати ЕАМ као, у најмању руку,

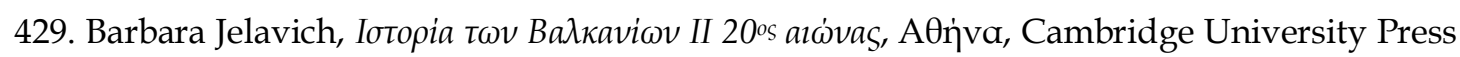
1983, oб. 439-441.

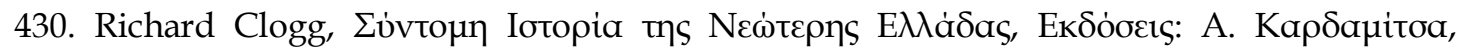
AӨท̀va, 1999, бo. 219-220. 
једнаког партнера у власти, али ни касније није одустала од тога. Тајно бегство преко 5.000 бораца ЕЛАС-а у специјалне логоре које су им препустили комунистички режими Албаније, Југославије и Бугарске, као и прикривање лаког и тешког наоружања прикладног за наоружавање војних јединица, нису одсликавали мирне намере КПГ. Грчка влада није била вољна да прихвати ове аргументе под изговором да се на тај начин штите револуционари ЕЛАС-а прогањани од стране власти ${ }^{431}$.

Након саветовања са Британцима, Грчка влада предвођена Софулисом, одлучила је да избори буду спроведени пре референдума. Избори су заказани за 31. мај 1946. године. Левичарске странке су се побуниле, сматрајући да тако рано расписивање избора не може да резултира правом сликом политичке воље народа, због постојеће атмосфере насиља и несигурности. Овакав став је, у неку руку, делио и Софулис. С друге стране, Британија је из унутрашњих разлога инсистирала је да се ствари одвијају према договору, у жељи да смањи велике обавезе које има према Грчкој и да се створи једна легитимна влада путем избора. Поред чињенице да су избори и званично проглашени за последњу недељу марта 1946. године, Грчка влада је прижељкивала да одржи власт и да одлаже изборе на неодређено време, макар док не буде имала пуну контролу над оружаним снагама и над државним службама 432.

Грчка влада је 4. децембра обавестила Савезнике да није урађена ниједна измена унутар земље и да би мало одлагање помогло мирнијем развоју ситуације и предложила је да се избори одрже у априлу433. Овакав став Грчке владе узнемирио је Американце, који су мислили да би евентуално одлагање избора могло изазвати озбиљне дипломатске компликације. Бернс је одговорио Грчкој влади да одлагање избора после 31. марта није исправно, и да Америчка влада верује да обнова

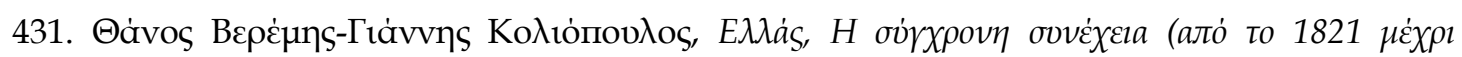

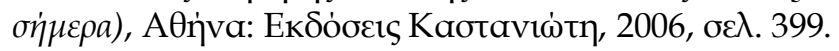

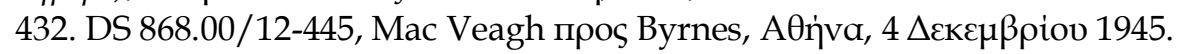

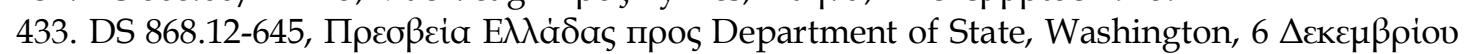
1945. 
државе, за коју је била потребна америчка помоћ, не може бити постигнута све док се политичка неизвесност наставља ${ }^{434}$.

До 21. фебруара из политичког штаба КПГ су најављивали да је та партија вољна да изађе на изборе, од којих је на крају одустала тврдећи да није постигнуто никакво побољшање терористичке атмосфере која је владала. Са одсуством левичарских партија, избори 31. марта 1946. године су биле, у суштини, борба између десничарске Народне странке и њених краљевских поборника, и растурених Либералних и десничарских партија које нагињу ка центру. Од 354 места у Скупштини, Народна странка и њени десничарски коалициони партнери освојили су 206, Национална политичка Унија, која представља савез три мање странке на челу са Софоклисом Венизелосом, Георгиосом Папандреуом и Панајотисом Канелопулосом, освојила је 68, Софулисови либерали 48 и Национална странка са генералом Наполеоном Зервасом 20 места. Савезничка Мисија за Надгледање Грчких Избора (AMFOGE) изјавила је да су избори били прецизан одраз народне воље, рачунајући да је проценат не-изласка на изборе из политичкх мотива 9,4\%. С друге стране, комунисти су тврдили да је гласало само 49\% од уписаних гласача, и да осталих 51\% представља левичаре који су бојкотовали изборе. У сваком случају, питање стварног броја левичарских гласача који су бојкотовали изборе остаје отворено, јер и процена AMFOGE-a је превише ниска, као што су и тврдње комуниста превише високе ${ }^{435}$.

Након неколико унутрашњих несугласица, Констандинос Цалдарис је стао на челу владе Народне странке. Са врло значајном већином у парламенту, Цалдарис је одредио датум референдума о монархији за 1. септембар 1946. године. Већ од 18. априла, новоформирана влада је дала на знање Американцима да намерава да референдум спроведе у што краћем року. Американци, међутим, су сматрали да свака помисао на референдум треба да се одлаже на 
неодређено. Сматрали су да је налажење решења на економска питања много битније од решења питања династије. Према мишљењу Америчке владе, референдум не би требао да се изврши пре пролећа 1947. године ${ }^{436}$. Једини начин да спрече Цалдариса да одустане од својих планова био је да се директно умешају у унутрашња дешавања у Грчкој. Постојала је опасност да на тај начин САД, без намере, учествују у рушењу владе. Најзначајнији разлог, који је приморао Американце да промене став, био је тај да је Велика Британија желела да референдум буде у року од шест месеци од одржавања избора. Британске трупе су требале да се повуку до јесени 1946. године, јер док год би продужавали њихов останак у Грчкој, било је сигурно да руске трупе неће отићи из Бугарске. Такође, ако би британске трупе отишле, било би немогуће спровести праведне изборе и било је врло могуће да буду покрадени. У том случају, са победом монархије, левичари би највероватније започели грађански рат, који би имао јако негативне последице $\mathrm{e}^{437}$.

Референдум је одржан нормално и резултат је био - 68\% (1.136.289 гласова) за монархију и 32\% (524.771 гласова) против. Референдум није био надгледан од стране AMFOGE-a, иако су Британија и Сједињене Државе преконтролисале бирачке спискове, и тврдње опозиције о невалидности избора потврђене су у поверљивим документима савезничких посматрача. Поред овога, постојао је толики поларитет на грчкој политичкој сцени да је изгледа један значајан број људи који нису били комунисти, а били су против монархије, гласао за повратак Краља, сматрајући га најбољом гаранцијом против освајања власти од стране комуниста. Краљ Георгиос II вратио се у Грчку 21. септембра, први пут након ужурбаног одласка са Крита у априлу 1941. године. Међутим, само шест месеци након доласка на трон, Георгиос умире у априлу 1947. године и на његово место долази његов брат Павлос.

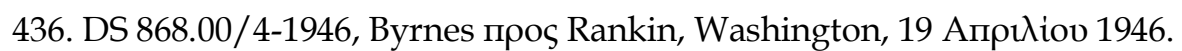

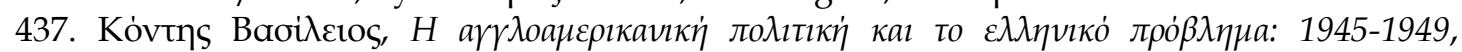

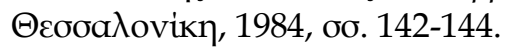


Спровођење избора и референдума 1946. године нису приближили Грчку некој политичкој стабилности коју је прижељкивала Британија. Цалдарисова влада, насупрот оној на челу са Софулисом, није показала политичку вољу да умањи расцеп између левице и деснице. Цалдарис је придавао много већу пажњу на грчке територијалне и друге претензије према другим државама, него ли на унутрашње измирење 438 .

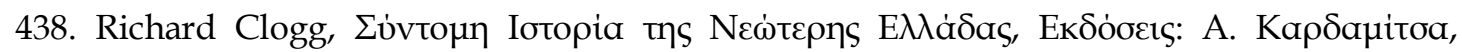
AӨท̀va, 1999, бo. 232-233. 


\section{4 СИТУАЦИЈА НА БАЛКАНУ ПОСЛЕ ДРУГОГ СВЕТСКОГ РАТА}

Крај Другог светског рата затекао је балканске земље, неке у мањој а неке у већој мери, да пребројавају ране и изгубљене људске животе као и огромну материјалну и економску штету коју су задобиле. Неизбрисиви су били и трагови које је рат оставио на политичкој сцени ових земаља, могло би се рећи са јединим изузетком Турске. Као што је познато, након завршетка Другог светског рата власт у балканским државама преузеле су комунистичке партије, са изузетком Грчке и Турске које су остале под утицајем Запада.

Ова промена власти није се десила у свим државама из истог разлога. У случају Југославије, као и Албаније, комунисти су веома брзо преузели власт захваљујући народној подршци коју су имали, а коју су задобили на фронту за време ослободилачке борбе против немачког окупатора. Партизани су представљали хероје и отпор који су показали прелазио је у сферу митског. Њихов вођа, маршал Тито, задобио је поверење и подршку народа као ослободилац земље ${ }^{439}$. Тито је истовремено био и вођа Комунистичке партије Југославије, док су и корпуси партизана били сачињени од људи који су били привржени комунистичкој идеологији, тако да је јасно да је преузимање власти од стране Комунистичке партије у очима народа изгледало праведно и оправдано, и десило се врло брзо и без значајнијег отпора. Слична ситуација десила се и у Албанији са преузимањем власти од стране тамошње Комунистичке партије, под вођством Емвера Хоџе.

У Бугарској и у Румунији ствари су се одвијале на другачији начин. Ове земље су потписали капитулацију снагама Осовине и нису

439. Гледајући ствари из ове перспективе, можемо рећи да без помоћи Црвене армије, он сам највероватније не би могао да преузме контролу над земљом и њеним главним градом, Београдом. Без жеље да умањимо стварно задивљујући отпор који су исказали партизани, морамо да нагласимо да су изрази попут "ослободиоци" и "спасиоци" земље, који су им приписивани и на чему су они заснивали преузимање власти, били вероватно претерани. 
пружиле неки значајнији отпор нацистима, изузев малобројних бомбашких напада. У њиховом случају популарност комуниста у народу остала је врло мала из разлога шта се нису истакли на бојном пољу, нити су учествовали у револуционарним покретима. У овим земљама, а посебно у Румунији, комунистичке партије су бројале само неколико стотина чланова и њихов одјек у народу је био веома ограничен. Јасно је да је њихово преузимање власти након рата било резултат присуства Црвене армије у региону, као и тежњи СССР-а да их стави под својим утицајем, а то је било могуће само са комунистичком партијом на челу ових држава. У Бугарској је ова промена власти извршена неометано, јер је бугарски народ увек гајио пријатељска осећања према Русима. Потврда тога је и статуа цара Александра II Николајевича, представљеног као ослободиоца земље, која постоји и до данашњег дана на централном тргу у Софији ${ }^{440}$. У случају Румуније, дочек Црвене армије је био доста хладан и наметање комуниста на власти било је доста теже 441.

Догађања у Албанији и Југославији изгледа да следе неку паралелну путању. Комунисти, у Албанији Хоџини а у Југославији Титови партизани, тријумфовали су на бојном пољу и тиме задобили масовну подршку у народу. Ова чињеница је утицала да Комунистичке партије ових држава веома лако преузму власт након завржетка рата.

Када је повлачење немачких снага већ било извесно, КПА је сазвала у октобру 1944. године други Конгрес албанског НОП-а. На конгресу је донешена одлука да Антифашистички Народноослободилачки Комитет буду проглашен за нову владу слободне Албаније, која је названа влада Националног фронта, на челу са премијером Елвером Хоџом. Изгледало је тада да је сарадња Демократског фронта (како је касније назван Народноослободилачки

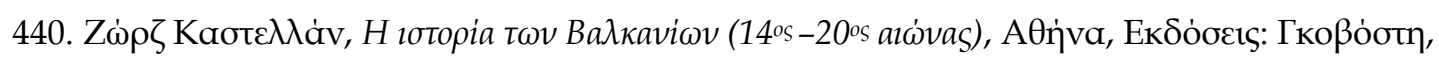

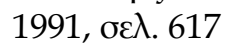

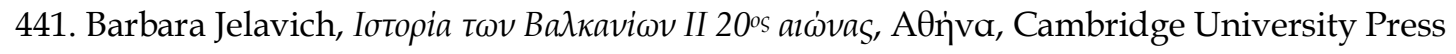

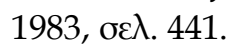


фронт) са осталим демократским снагама сачувана. Међутим, временом је постојао све већи утицај од стране КПА на Демократски фронт, да би на крају постао марионета у рукама Комунистичке партије. У склопу реформи које су већ биле започеле, у децембру 1944. године су национализоване индустрија, банкарски сектор и превоз. Такође, одузета су индустријска, трговачка и пољопривредна власништва од људи који су напустили земљу из политичких разлога, без обештећења бившим власницима ${ }^{442}$.

На војном плану постојале су и даље операције, углавном на северу Албаније, јер је долазак партизана у области које нису биле под њиховом контролом проузроковало оружану побуну Гега, Албанаца насељених северно од реке Шкумбин. Ови устанци су потврдили слаб утицај који је имала КПА на северу државе. Три четвртине њених чланова су били Тоске, насељени јужно од Шкумбина. Велики број противника власти на северу земље сматрали су комунизам у Албанији једну врсту завере од стране Тоска да преузму власт и у тим северним крајевима ${ }^{443}$. У исто време, хиљаде присталица организација Бали Комбетар и Легалитет напустили су земљу и настанили се у Америци ${ }^{444}$.

Албанска влада у јануару 1945. године почиње са прогањањима својих политичких ривала, што је било уобичајена пракса и у осталим балканским државама, користећи против њих оптужбе типа „ратни злочинци“, „кривци“, „државни непријатељи“. У почетку су хапшења била у великој мери оправдана јер су постојали докази за сарадњу са непријатељем, али недуго затим основане су десетине народних судова који су безобзирно осуђивали политичке противнике комуниста и слали их у радне логоре и у затворе 445 .

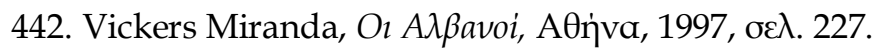

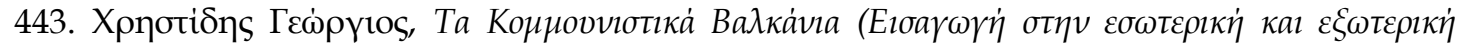

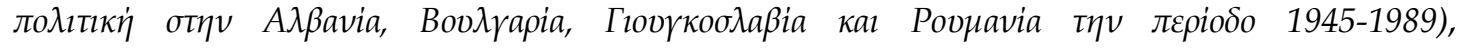

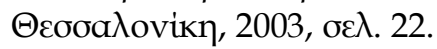

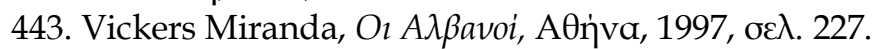

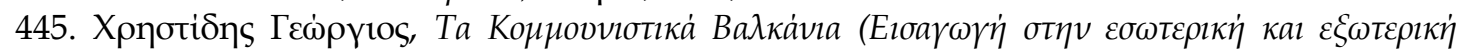

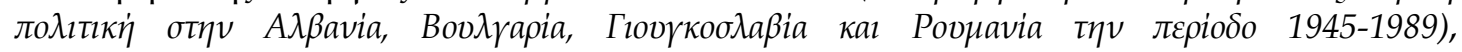

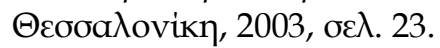


Доминација на власти од стране КПА завршена је марта 1946. године, када је изгласан нови Устав ${ }^{446}$ којем је Албанија проглашена за Народну републику и тиме је утемељена „диктатура пролетеријата“. Албанска Народна скупштина изабрала је нову владу у којој је Хоџа задржао место председника, као и место Генералног секретера КПА4․

Период Другог светског рата био је и за Југославију од пресудног значаја за послератно стање ствари у земљи. Распад постојећих политичких институција, у комбинацији са општим расулом који је владао током рата, дозволили су КПЈ да постане најзначајнија политичка снага у држави захваљујући веома значајној улози у борби против окупатора ${ }^{448}$. Титов тријумф заокружен је доласком Црвене армије у септембру 1944. године. Титове снаге ослободиле су главни град Југославије 20. септембра, док је Недићева влада покушала да побегне у договору са малобројним Михајловићевим четницима, али је већ било касно за тако нешто ${ }^{49}$. У међувремену Британија је успела да потпише низ уговора са Краљевском владом Југославије у изгнанству, која се у почетку налазила у Лондону, а касније у Каиру, и која је била једина призната влада те земље од стране великих сила. Тим уговорима договорено је да влада у изгнанству даје подршку партизанском покрету, као и да ће послератна југословенска држава бити федералног типа и да ће питање уређења политичког система бити решено кроз избор Уставотворне скупштине. Паралелно са тим договорено је учешће чланова избегличке владе у послератној влади Југославије, док би један одбор намесника био представник Краља Петра Другог све до коначног

446. Претходили су избори за формирање Конституционалне сједнице у децембру 1945. године, у којима је Демократски фронт добио 91,88\% гласова.

447. Емвер Хоџа успио је да се одржи на власти 40 година, све до своје смрти 1985. године, док је КПА владала Албанијом све до почетка 90-их година прошлог века.

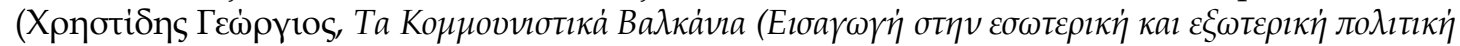

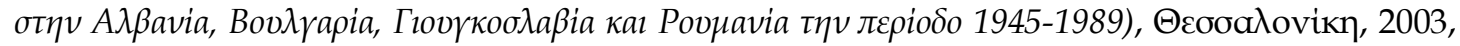

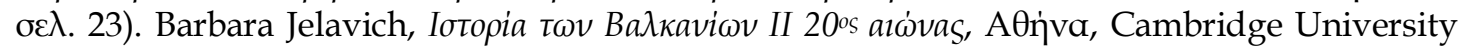
Press 1983, oع $\lambda .456$.

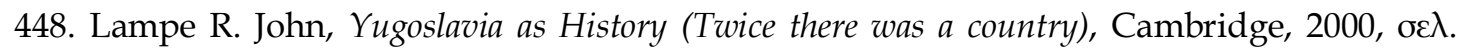
201.

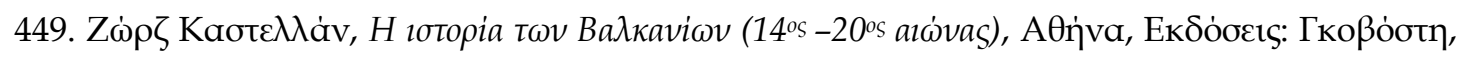

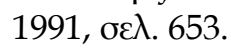


решења уређења политичког система. Ове одлуке су озваничене на Конференцији у Јалти која је одржана од 4. до 11. фебруара 1945. године 450 .

Након повлачења немачких трупа сви они који су проглашени ратним злочинцима и сарадницима окупатора изгубили су сву своју имовину, у складу са законом о национализацији који је донешен новембра 1944. године ${ }^{451}$. У марту 1645. године оформљена је привремена влада у којој су учествовали и чланови избегличке владе, у складу са потписаним уговорима из 1944. године. Главни циљ ове владе био је припрема избора за састав Уставотворне скупштине. У августу 1945. године КПЈ формира Народни фронт који је окупљао све напредне снаге $^{452}$. На изборима одржаним 11. новембра 1945. године Народни фронт, који је био под контролом комуниста, освојио је 90\% гласова 453 .

Нова Уставотворна скупштина донела је 29. новембра 1945. године одлуку о прекиду монархије и прогласила Федеративну Репулику Југославију, које су сачињавале шест република и две аутономне покрајине. Нови устав изгласан је 31. јануара 1946. године који Југославију проглашава за Федеративну Народну Републику. Комунисти су са оваквим развојем догађаја потпуно преовладали државном политичком сценом. Новоизгласани Устав одсликавао је у потпуности

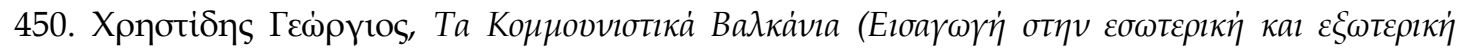

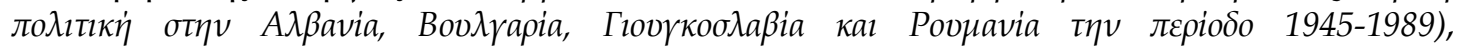

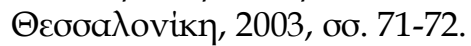

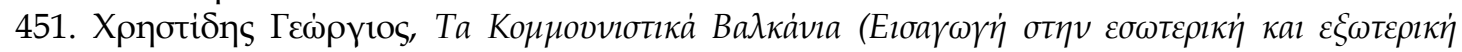

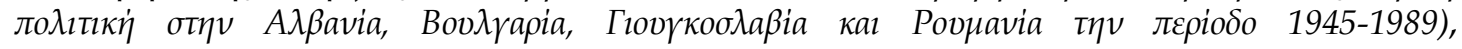

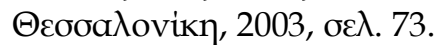

452. Врло брзо је било јасно да се ова нова политичка творевина налазила под контролом КПЈ. Период који је уследио био је предизборног карактера са крајњим циљем избор Уставотворне скупштине. Утврђене су разне неправилности од стране КПЈ, као и притисци према осталим опозиционим партијама, које нису биле у Народном фронту, да не изађу на изборе.

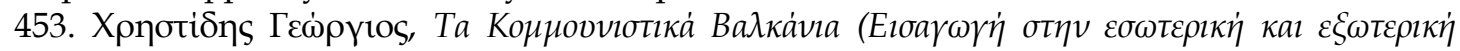

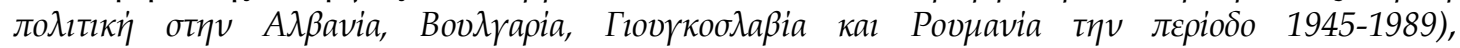

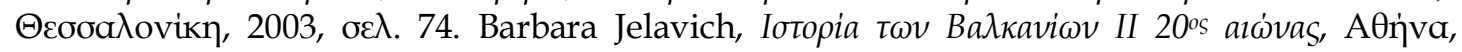
Cambridge University Press 1983, oo. 453-454. 
ставове КПЈ у том периоду, и био је написан по угледу на Совјетски устав из 1936. године 454 .

У Југославији је, слично као и у Албанији, уследио процес национализације индустријског, банкарског и трговачког сектора, као такође и свих осталих начина производње и приватне својине. Што се тиче мало броја преосталих политичких супарника комунистичке партије, они су убрзо били уклоњени или притворени под оптужбама типа „ратни злочинци“, „кривци“, „државни непријатељи“. То је процес сличан оном већ виђеном у Албанији, али можемо рећи да се ради о уопштеној пракси које су се придржавале комунистичке партије на Балкану са циљем уклањања својих политичких супарника ${ }^{455}$.

КПБ је имала предност у томе да је јавно мњење у Бугарској из принципа било проруски оријентисано, као и да је и пре рата била најјача и најмасовнија комунистичка партија на Балкану. И поред тога, преузимање власти од стране комуниста није било толико једноставно. Са инвазијом Црвене армије у Бугарској одмах се формирала влада Народног фронта, која је имала у својим редовима све напредне демократске снаге, са премијером Кимоном Георгијевом из војнополитичке организације Звено. У овој влади Бугарска Радничка партија, како се тада називала комунистичка партија, је заузела политички веома битна министарства Унутрашњих послова и Правде $\mathrm{e}^{456}$.

Иако је Бугарска формално остала уставна монархија, Краљ је био веома млад и његову улогу преузело трочлано намесништво, тако да је

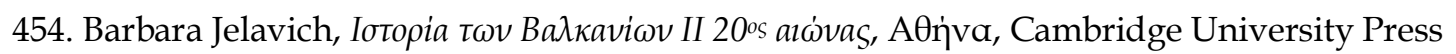
1983, об. 454-455.

455. У склопу ове политике, у марту 1946.год. основана је Управа државне безбедности, на челу са Александром Ранковићем, која је наследила Организацију народне одбране.Управа државне безбедности примењивала је једну врсту „легалног тероризма, имајући на располагању неограничену моћ да хапси, затвара, па чак и да погубљује

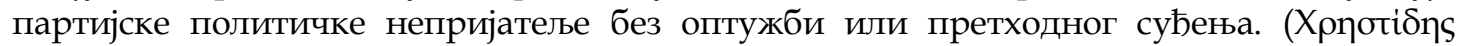

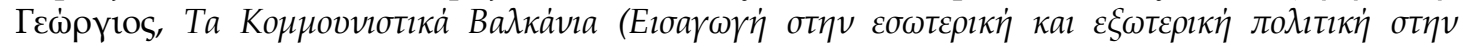

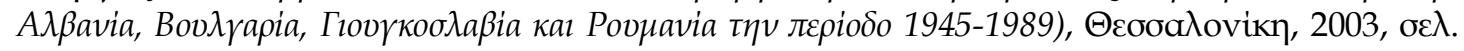
75).

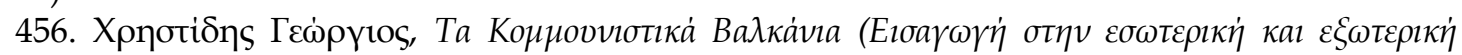

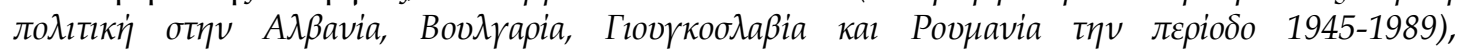

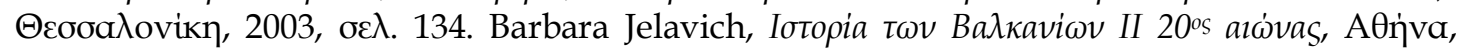
Cambridge University Press 1983, oع入. 448. 
најзначајнији орган власти у земљи био Национални одбор Народног фронта, који је контролисан од Радничке партије Бугарске. Такође велики значај за утицај који су уживали комунисти имале су разни локални одбори које је основао Народни фронт одмах након уласка совјетских трупа у земљу. На овај начин РПБ имала је врло добро организовану информативну мрежу, којом је вршила утицај дуж читаве земље. Рад ових одбора, у комбинацији са чињеницом да су комунисти контролисали министарство Унутрашњих послова и министарство Правде, омогућио им је да изврше јак напад на своје политичке противнике. Представници претходне власти су, или били хапшени и затварани, или су били ликвидирани. Дуж читаве земље формирају се народни судови који осуђују све политичке противнике РПБ као подржаваоце претходног режима и сараднике немачких снага. Ова суђења су претстављала једну врсту правног инструмента за уништавање бугарске политичке и економске елите ${ }^{457}$.

Након ове прве фазе обрачунавања са својим политичким ривалима, РПБ је покушала да стави под своју контролу и лидере осталих партија које су учествовале у Народном фронту 458. Парламентарни избори су одржани 18. новембра 1945. године. Унутрашњи сукоби у самом Народном фронту били су велики. Под притиском РПБ, која је подржавала да Народни фронт изађе на изборе са заједничком листом, присталице Николе Петкова и Лулцева, вође

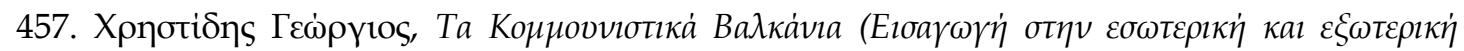

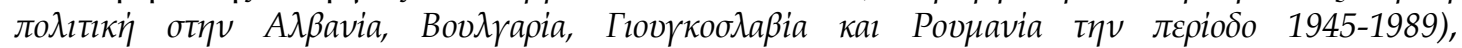

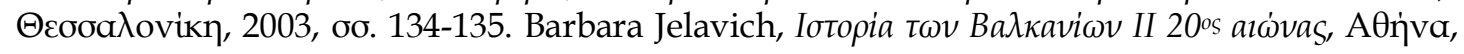
Cambridge University Press 1983, or. 448-449.

458. Најзначајнија партија међу њима била је Бугарска Национална Земљорадничка Унија, и из тог разлога први напади комуниста су имали за мету управо њу. Оптужили су њеног вођу Г. Димитрова да је енглески шпијун и на тај начин га прилили да поднесе оставку и напусти земљу. Вођство Бугарске Националне Земљорадничке Уније преузима Никола Петков, један харизматични политичар који је успео да постане највећи политички ривал комунистима. Притисци и над осталим политичким партијама су настављени, и као резултат тога имамо расцеп Бугарске Националне Земљорадничке Уније и Социјалдемократске партије на прокомунистичке и

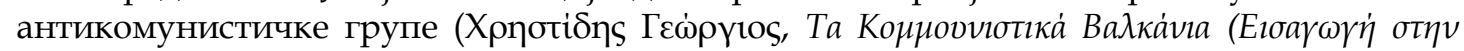

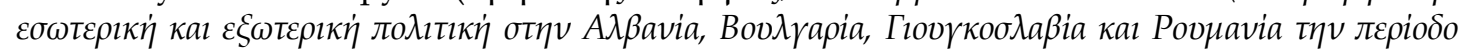

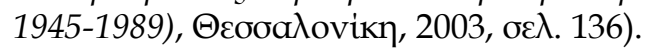


антикомунистичког крила социјалдемократа, одлучили су да бојкотују изборе. Народни фронт је добио 88,14\% гласова, али Петков и Лулцев су одбили да признају резултате изборе и тражили су њихово поништавање и одржавање нових. На крају је криза избегнута уласком два члана опозиције у владу459.

Нова влада, на челу са Генералним секретаром РПБ Г. Димитровим, отпочела је са великим еланом припрему нове политичке и економске стварности у Бугарској, не придајући велики значај захтевима опозиције да се поштују Устав и демократски принципи. У исто време почео је нови талас прогањања преосталих политичких противника РПБ. Након тога влада Народног фронта спроводи референдум о врсти политичког система, и организује изборе за формирање Уставотворне скупштине. На референдуму који је одржан 9. септембра 1946. године, 95,6\% бугарског народа је гласало за Немонархичну републику, тако да је Краљ био принуђен да напусти земљу. На изборима за формирање Уставотворне скупштине Народни фронт је сакупио 70,1\% гласова и 366 мјеста, од којих је 277 припало РПБ${ }^{460}$. Опозиционе партије Петкова и Лулцева добиле су само 101 места у парламенту. Као резултат овога, РПБ је имала контролу над Националном скупштином, а за премијера земље изабран је још једном Генерални секретар РПБ Димитров ${ }^{461}$.

Радничка партија Бугарске је задала завршни ударац својим противницима након потписивања мировног споразума са Савезницима 1947. године. Бугарска скупштина је 5. јуна затражила и добила

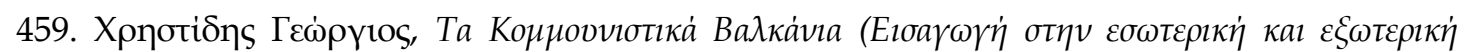

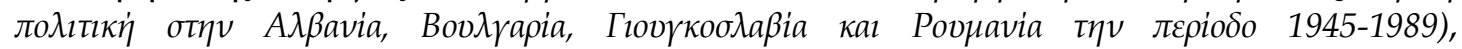

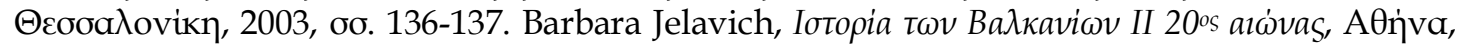

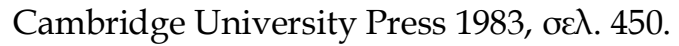

460. Овог пута Отаџбински фронт је изашао на изборе као уједињени блок, али са одвојеним гласачким листама партија које су га сачињавале. Из тог разлога постоји ова подјела посланичких места Отаџбинског фронта са местима која припадају РПБ.

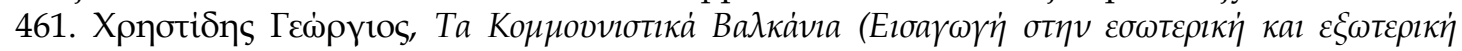

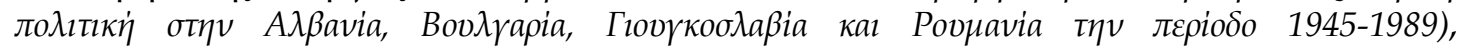

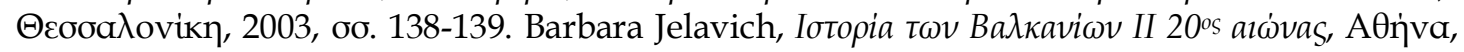
Cambridge University Press 1983, oo. 450-451. 
одузимање имунитета Петковом, под оптужбом да је учествовао у организовању државног пуча. Петков је ухапшен, и након суђења пародије осуђен је на смрт вешањем које је извршено 5. септембра 1947. године. Петкова смрт је, на неки начин, представљала крај опозиције. То је такође означавало коначну превласт комуниста јер, са једне стране, није више постојала у редовима опозиције ниједна личност Петковог калибра, а са друге је страх је затворио уста осталих чланова опозиције. Бугарска скупштина је 4. новембра 1947. године изгласала нови устав, који је у суштини био репликат совјетског устава из 1936. године, и њиме је Бугарска проглашена Народном републиком ${ }^{462}$.

У Румунији се долазак комуниста на власт показао као веома тежак процес, а један од главних разлога био је антируско расположење које је владало у јавном мњењу. За веома изражени антибољшевички став Румуна допринео је и став Москве у вези низа догађаја који су се тицали њихове земље, међу којима је најзначајнији био окупација области Бесарабије. Након повлачења немачке војске створена је влада Националног уједињена, са учешћем и једног представника КПР. На овај начин прекинут је двадесетогодишњи илегални рад ове партије. Са уласком совјетских трупа у Букурешт 31. августа, и потписивањем мировног споразума нове владе Румуније са Савезничким снагама 12. септембра, Румунија прелази у потпуности под утицајем Москве. Овакав расплет догађаја ће убрзо утицати на политичку ситуацију у земљи и довести на власти КПР.

Санатескуова влада се врло брзо нашла у проблемима и Национални демократски блок се распао ${ }^{463}$. На иницијативу КПР, 12.

462. Разлог разлаза било је одбијање Земљорадничке странке и Либералне партије да прихвате примењивање мера које је предлагала КПР. Између осталог, те мере су подразумевале почетак једне врсте земљорадничке реформе, пренос већих права за

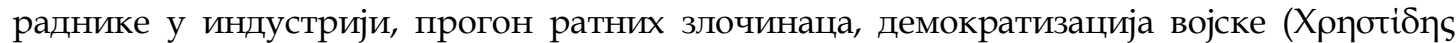

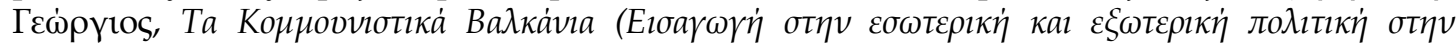

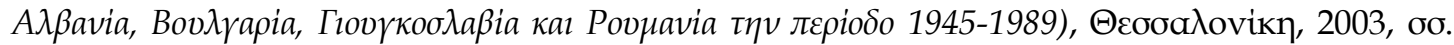

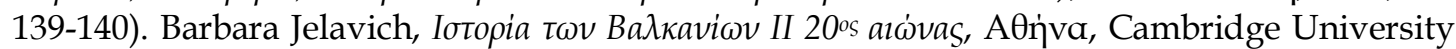
Press 1983, oo. 451-452.

463. Stephen Fisher-Galatia, "Prelude to Communist Totalitarianism", Dinu C. Giurescu,

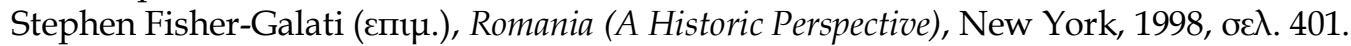


октобра 1944. године формира се нова коалиција под именом Национални демократски фронт, у којем учествују Социјалдемократска партија, Земљораднички фронт, Савез патриота, Домовинска одбрана и Савез мађарских радника Румуније ${ }^{464}$. Криза у власти која се створила на овај начин, превазиђена је након одлучне интервенције Москве, и стварања нове владе под вођством генерала Санатескуа, у којој на министарским позицијама комунисти и њихови савезници имали повећану моћ 465 .

Убрзо се створила нова криза, да би након нове интервенције СССР-а на политичкој сцени Румуније Санатескуова влада била приморана на оставку децембра 1944. године. Ствара се нова влада под вођством генерала Радескуа ${ }^{466}$. Снага КПР је почела да расте великом брзином ${ }^{467}$. Крајем јануара 1945 . године КПР почиње са организацијом низа протестних скупова, са којима захтевају праву демократизацију земље, прогон и узорно кажњавање фашистичких и реакционих елемената ${ }^{468}$. Радескуова влада је покушала да одговори на ове протесте. У фебруару 1945.године силом разбија један скуп који је организовала

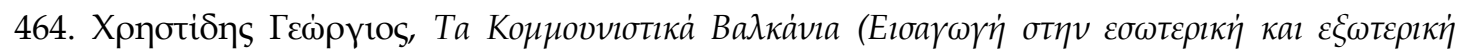

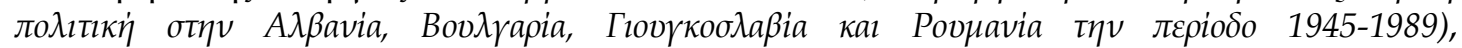

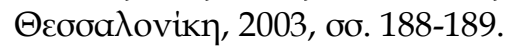

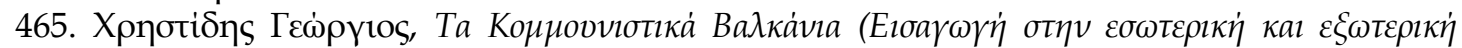

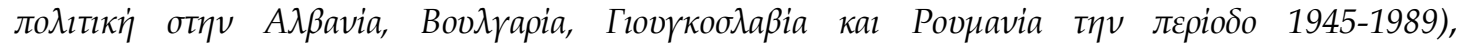

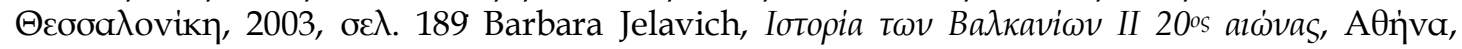
Cambridge University Press 1983, oo. 443-444.

466. Детаљније о томе како је препуштен избор владе генералу Редескуу, на који начин су се умешали Совети на политичкој сцени Румуније, и која је била улога, министра спољних послова СССР-а, Висинског у томе погл. Dinu C. Giurescu, Romania's Communist Takeover: The Radescu Government, New York, 1994, oo. 18-19.

467. Долазак водећих личности из групе КПР која је била организована у Москви, између којих су били Ана Паукер, Георгиу Дез и Василе Лука, допринела је још више

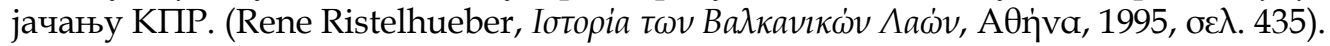

468. 28/1/1945 Национални демократски фронт, који је у суштини под утицајем комуниста, објављује политички манифест који је садржао све основне полити.чке ставове комуниста, као шта су развој сарадње и пријатељства са Уједињеним нацијама и, пре свега, са СССР, које су представљале „великог комшију“, демократизација војске, примерно кажњавање свих „ффашиста“ и др. погл. Dinu C. Giurescu, Romania's Communist Takeover: The Radescu Government, New York, 1994, oo. 32-35. 
КПР, док Радеску лично оптужује Ану Паукер и Василеа Лука да су шпијуни ${ }^{469}$.

У марту 1945., након указивања од стране Москве и договора са крањем Михаилом, власт у земљи преузима Петар Грожа, вођа Земљорадничког фронта ${ }^{40}$. Утицај КПР у новој влади се увећао, тако шта њени чланови преузимају министарства унутрашњих послова и правде, као и водеће позиције у румунској војсци ${ }^{471}$.

Новоформирана влада предузима низ мера којим успева да стави под своју контролу државне миханизме и да саботира опозицијуㄱ․ међувремену, све више високих чланова КПР преузимају места управника округа у локаним самоуправама, и у свим градовима се формирају општински одбори са повећаним надлежностима, која су била под контролом чланова КПР 473 . Уз подршку и са присуством

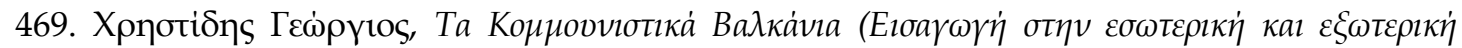

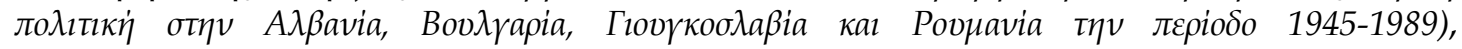

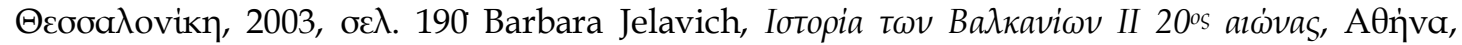
Cambridge University Press 1983, об. 444-445.

470. Министар Висински је још једном одиграо одлучујућу улогу. Посетио је краља Михаила у Букурешту и саопштио му да треба одмах да се расформира Радескуова, и да буде изабрана нова влада. Одабрали су и јединог кандидата који је поседовао све квалитете да формира нову владу. То није био нико други до Петра Гроже. Смернице из Москве су морале да буду извршене, и тако је краљ био приморан да 6/3/1945 прогласи избор нове владе. Погл. Georges Castellan, A History of the Romanians, New York, 1989, бо. 223-224.

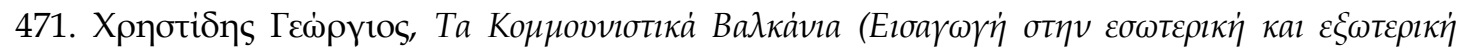

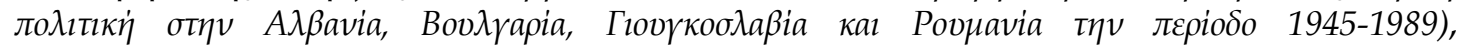

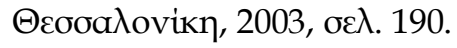

472. Карактеристично је да је нови министар унутрашњих послова Георгеску, који је долазио из редова КПР, изјавио да треба да ступи на снагу нови систем строге полицијске контроле са циљем хапшења свих фашиста и њихових сарадника, као и прикупљање елемената који су били корунпирани са антидемократским деловањем и примањем мита. Наравно, под овим уопштеним изјавама постајале су широке могућности интерпретације који су то људи, и на који начин, сарађивали са фашистима, и који поседују демократске идеале. У почетку се чинило да су ухапшени неки долазани кривци. Међутим, како је време одмицало, Грожина влада је исказивала све више своје диктаторско лице и користила је горе наведене ставове као изговор за хапшење сваког антирежимског елемента. (Dennis Deletant, Romania under Communist

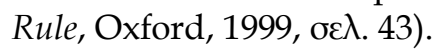

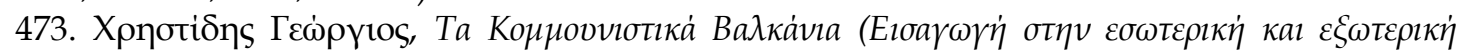

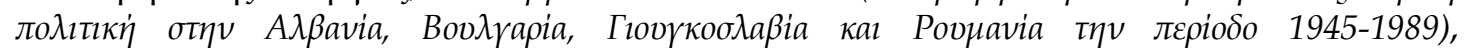

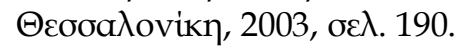


Црвене армије, КПР почиње да се утемељује дуж читаве државе, да прикупља на хиладе чланова и постаје прва политичка снага у земљи ${ }^{474}$. У мају, КПР је објавила форирање Блока Демократских снага који ће изаћи са јединственом листом на изборе, на којима ће, поред КПР, учествовати Социјалдемократска партија, једна огранак Либералне партије, Земљораднички фронт и пар мањих странака ${ }^{475}$. Резултати избора, који су одржани 19. новембра 1946. године, донели су пет милиона гласова Блоку Демократских снага (84\%) и 384 посланичка места. Национална народна странка добила је око 800.000 гласова, док је Либерална партија освојила нешто мање од 300.000 гласова, тако да је опозиција изборила 66 посланичка места ${ }^{476}$. Нова влада је оформљена 1. децембра 1946. године под вођством Грожа ${ }^{477}$.

Након потписивања мировног споразума, 10. фебруара 1947. године, Грожина влада, која је у потпуности преовладала домаћом

474. У овоме је помогла и реформа у земљорадњи које је спровела Грожина влада. Том реформом су национализована сва земљишта преко 50 хектара и одузете имовине свима који су били под сумњом да су сарађивали са фашистима. Са овом прерасподелом земље, КПР се надала порасту поппуларности у редовима земљорадника, у чему је и успела. Пораст броја чланова КПР је импресиван. Са 1.000 чланова, колико је имала почетком 1944.године, њене снаге су повећане на 35.000 чланова у мату 1945., и на 256.000 у октобру истте године. Изгледа да је овај за пораст стварно заслуга ове реформе којом је подијењена земља земљорадницима. Такође велики број нових присталица били су и радници великих индустрија и фабрика, али доста њих је изгледа из корена променило своја политичка уверења и постали чланови партије да би избегли прогањање као могући сарадници фашистичких снага.

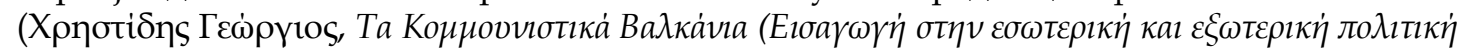

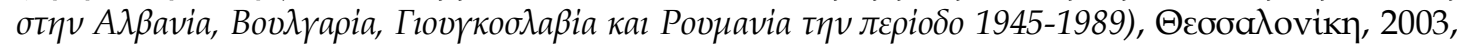

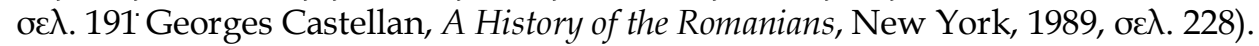

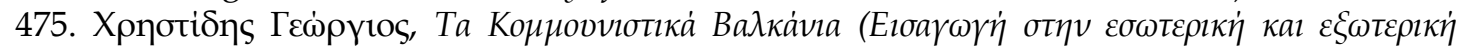

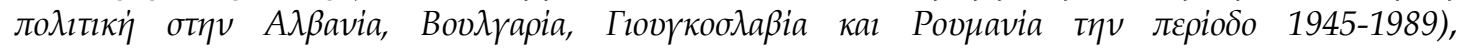

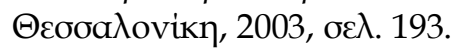

476. Морамо нагласити да се чињенице, у зависности од извора, благо разликују. Подаци који су изнешени горе су од Dennis Deletant, Romania under Communist Rule,

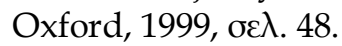

477. Званични резултати избора можемо рећи да и нису баш најзаконитији. Карактеристично је да су за западне дипломате и новинаре подаци о изборима били лажни. С.А.Д. су изјавиле да неће признати резултате избора, и заменик министра спољних послова Мекнил је нагласио да избори нису били ни слободни, нити праведни. Опозиционе партије, као што је и очекивано, нису признали резултате

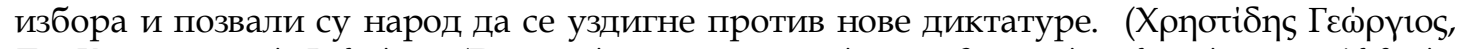

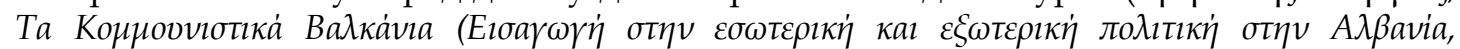

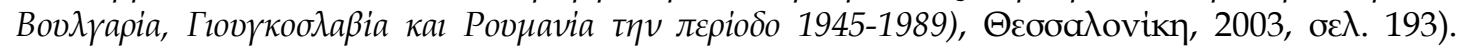

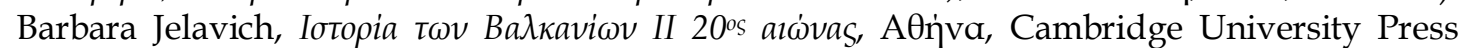
1983, oб. 446-447. 
политичком сценом, окреће се против својих преосталих политичких супарника. Прогони су били масовни и подразумевали су сваки антирежимски елемент, јер је у народу владао страх због врло оштре полицијске контроле и због агената тајне службе полиције, који није остављао изгледа за било какву реакцију78. Циљ ових масовних хапшења и прогона свих оних који би показали било какав отпор према одлукама владе, био је заплашивање становништва, као и коначан, потпуни обрачун са политичким противницима. Овај циљ је, на крају, и постигнут ${ }^{479}$.

Последњи остаци старог режима избрисани су 30. децембра 1947. године када је Краљ Михаил, након договора са Грожем и Георгијем Дезом, принуђен да се одрекне трона. Истог дана је влада прогласила Румунију Народном републиком, и отпочела припреме за нови устав 480 . Одлазак Краља из земље означио је коначну и неопозиву превласт Совјетске политике у земљи, као и монопол на власти који су уживали комунисти на унутрашњој политичкој сцени. Као резултат горе наведених чињеница била је убедљива победа Румунске радничке партије, како је био нови назив Комунистичке партије након удруживања са левичарским делом Социјалдемократске странке, на

478. Рачуна се да су у току 1947.године извршена преко 60.000 хапшења и егзекуције политичких противника КПР. Већина њих су извршене без довољних доказа. У доста случајева, министар унутрашњих послова Георгеску се служио уопштеним одговорима типа „били су чланови фашистичких организација“, или „били су ратни злочинци“. На овај начин је мпгао да дели оптужбе по слободној процени и расположењу.

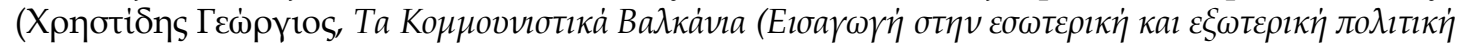

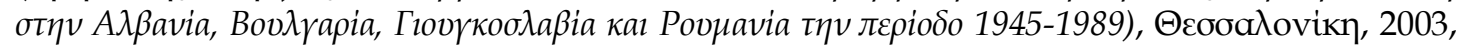

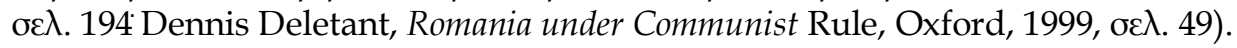

479. Међу хиладама хапшења које су се збила у овом периоду, била су и хапшења двојице историјских вођа. Један од њих је Маниу, вођа бивше Радничке странке, а други је Михалаке. Обоје су осуђени на доживотну робију. Са оваквим развојем ситуације, један од последњих слободних елемената у Грожиној влади, министар спољњих послова Татареску даје оставку на функцију и на његово место поставња се Ана Паукер, док је за министра економије постављен Василе Лука. Више није постојало питање за старије странке, као што су либерална, националистичка, национална, земљорадничка и социјалдемократска. Комунизам који тријумфује прелазио је у фазу растурања градског сталежа и одважних сељака. (Rene Ristelhueber, Iбторіа $\tau \omega v$

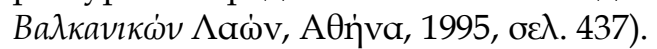

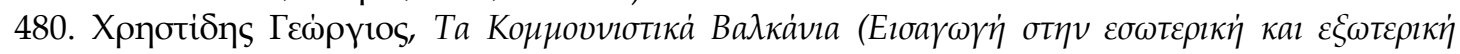

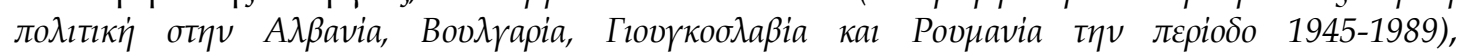

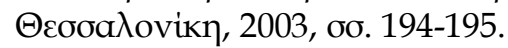


изборима 1948. године са 91\% гласова. Са новим уставом, изгласаном 13. априла 1948. године, постављени су темељи за процес који је започињао, а то је покушај изградње социјализма 481.

Следи анализа о судбини комуниста у Грчкој након завршетка Другог светског рата. Случај Грчке се поприлично разликује од осталих балканских земаља. Грчка је била једина држава на Балкану, ако изузмемо Турску, у којој на власти није била комунистичка партија. Пример Грчке је доста сличан примерима Југославије и Албаније. Грчки комунисти су били ти који су на својим плећима подигли највећи део отпора против окупатора, организујући у почетку мале побуњеничке групације, а у наставку Народноослободилачки фронт, чије је војно крило била Грчка ослободилачка восјка. Слично као у Албанији и Југосалвији, грчки побуњеници су издржали нападе немачких трупа, и преовладали над осталим националистичким побуњеничким групама.

Основни разлог због чега комунисти нису успели да преовладају у Грчкој био је тај да Британија није хтела да дозволи да још једна држава са Балканског полуострва падне под утицајем Совјета, и да у њој преузму власт комунисти. Наиме, на тајном састанку октобра 1944. године који је претходио између вођа Британије и Совјетског савеза, Черчила и Стаљина, овај последњи није имао ништа против предлога да Грчке буде 90\% под британским утицајем. Изгледало је да је Грчка изван стратешких планова Совјетског савеза. Без помоћи СССР-а, и без присуства Црвене армије, није био могућ долазак на власт комуниста у Грчкој. Међутим, комунисти су сматрали себе као ослободиоце земље и веровали су да им оправдано припада право да буду на власти. Нажалост за комунисте, али и за Грчку, која је ушла у дугачак период националног раздора и прошла кроз два грађанска рата, Грчки комунисти нису имали праву визију. Нису прихватили никакву врсту договора која им је

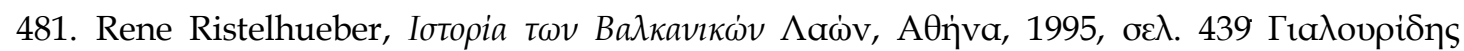

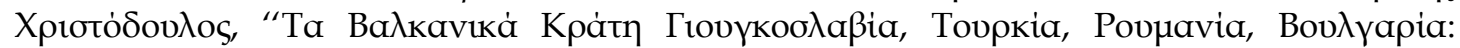

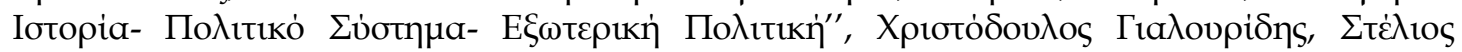

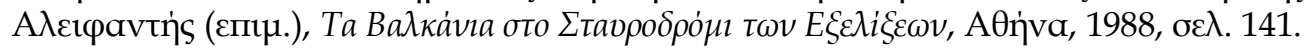


понуђена, већ су хтели да имају потпуну власт у својим рукама. Ово је резултирало почетком једне узалудне борбе за власт, где помоћ од стране Совјетског савеза никад није пристигла.

Тачније, Енглези су били веома умешани у стање ствари у Грчкој током Другог светског рата, јер је за Британију она представљала приротет у спољњој политици. У почетку су имали благу тактику да ојачају антикомунистичке побуњеничке снаге ЕККА и ЕДЕС-а. Међутим, убрзо НОП је проширио своју превласт дуж читаве земље, бројећи скоро 120.000 чланова. Из тог разлога Британија одлучује да посредује у постизању договора између побуњеничких снага. Изасланици из три побуњеничке организације састали су се са представницима избегличке Грчке владе на конференцији у Каиру. Конференција је завршена безуспешно, иако су се побуњеничке организације договориле су се о формирању владе Националног јединства у послератној Грчкој, нису могле да се усагласе око процента учешћа сваке организације у њој.

ЕЛАС се снабдела са прилично великом количином војне опреме од италијанских војничких групација, које су се повлачиле, и хтела је да расчисти, једном за свагда, са ЕДЕС-ом. Отпочела је снажну офанзиву у октобру 1943. године. Након обрачунања снага ЕЛАС-а са ЕККА, НОП је сматрао да је довољно јак, и ораганизовао је у областима које је држао под својом контролом једну врсту „државе у планини“. С друге стране ЕАМ је исказивао свој „заједнички карактер“ према осталим народноослободилачким снагама. ЕАМ је направио још један корак даље, након што је оформио једну врсту привремене владе под називом „Политички Комитет Националног Ослобођења“, организовао је 10.марта незаконите изборе на којима се процењује да је учествовало два милиона Грка.

Влада у избеглиштву је унапред реаговала на овакав развој догађаја и поставила је на свом челу Г. Папандреуа, који је у оквиру своје политике под паролом „једна отаџбина, једна влада, једна армија“, 
позвао представнике свих предратних политичких странака и представнике свих снага отпора на састанаку у граду Дар ел Сауер, у Либану. Ту је, након преговора, потписан Либански споразум. Према том споразуму предвиђено је формирање Владе националног јединства, којој су требале да се потчине све оружане снаге отпора, и у којој ће ЕАМ-у припасти четири министарства, док би питање врсте режима и повратак Краља било одлучено путем референдума. У октобру 1944. године немачке трупе напуштају Грчку, и истовремено се искрцавају у Пиреју Г. Папандреу и енглески командант Скоби са 4.000 војника, са наређењем да спроведу у праксу одлуке Либанског споразума. 


\section{5 ПРОБЛЕМИ И РЕЗУЛТАТИ ГРЧКИХ НАЦИОНАЛНИХ ПРЕТЕНЗИЈА}

Главни циљ грчке спољне политике 1945. године биле су, поред обезбеђивања економске помоћи за обнову земље, националне претензије које су се тицале сигурности државе, али су имале и историјску основу. Грчка је претендовала на Северни Епир од Албаније и на Додеканез од Италије, и постигла је нови споразум за разрешавање грчко-бугарске границе, да би престала да буде стратешки незаштићена на провокације од стране Бугарске, која ју је већ напала три пута од почетка 20-ог века ${ }^{482}$. По питању грчко-југословенске границе и Кипра, Грчка влада је избегавала свако званично изјашњавање ${ }^{483}$.

Послератне претензије Грчке владе сажео је Филипос Драгумис, заменик министра Иностраних послова, 1. августа 1946. године, истичући да Грчка треба да остане на страну светских поморских сила, које одражавају либералне демократске идеје и „принципе западне цивилизације“. Грчки дипломата је подржавао став да би савез Грчке са Британијом и САД-ом био више у складу са њеном историјом и њеним положајем на Средоземљу. Осврћући се на националне претензије, изјавио је да Грчка претендује на Северни Епир од Албаније, Додеканез од Италије и једно ново уређивање грчко-бугарске границе. Истакао је, такође, да многе суседне државе имају намере које иду на штету њеног територијалног интегритета и њене независности, и да је циљ јужнословенског империјализма био увек да имају излазак на Средоземно море преко Егеја и преко „леша грчке државе“. Тврдио је да Грчка може да спречи такав сценарио само под условом да има

482. За потпуне преговоре грчких претензија погл. меморандум грчке владе америчкој влади, 12. јун 1942. године, Xydis, Greece and the Great Powers, Пара́ 696 и меморандум Филипоса Драгуниса америчкој влади, Каиро 9.септембар 1944.год., DS 868.014/9-944.

483. Да не би наљутила Енглезе, грчка влада није се дотакла питања Кипра (Kóvtns

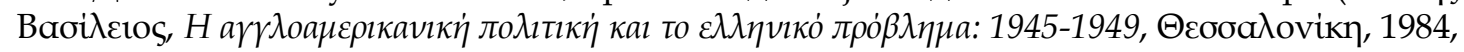

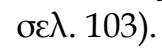


британско-америчку материјалну и моралну подршку484. С друге стране, грчки комунисти су прижељкивали стварање што јачих веза са СССР-ом и доминацију режима народне републике, јер су сматрали да само такво уређење може да да̣̂ решења на социјалне, економске и политичке проблеме у Грчкој ${ }^{485}$.

У Паризу је 25. априла 1946. године одржан Савет министара Иностраних послова. Филипос Драгумис, заменик министра Иностраних послова Грчке, је почетком маја саопштио министру Бернсу да Грчка има територијалне претензије према Албанији и Бугарској из безбедоносних разлога, и истакао да ниједна Грчка влада неће потписати мировни споразум који јој неће гарантовати апсолутну сигурност. Бернс није заузео јасан став према овим изјавама, али је истакао да сигурност Грчке, као ни ниједне друге државе, не може бити остварена територијалним променама, и да се нада за свеопшту сигурност налази у Уједињеним нацијама. Што се тиче Додеканеза, он је истакао да су се чланови Савета првенствено сложили да она припадне Грчкој, али да СССР до тог тренутка одбија да прихвати коначан договор по овом питању 486.

Министри Иностраних послова су се 8. маја усагласили да, чланом 1. бугарског мировног споразума, граница Бугарске треба да буде остављена онако како је била 1. јануара 1941. године. Садржај споразума неће бити озваничен пре него владе Грчке и Бугарске не искажу своје ставове на ту тему487. Молотов је предложио да Додеканез буде дат Грчкој, чим буде потписан мир са Италијом и чим се разоружају 488 . На првом заседању Савета министара Иностраних послова ниједна од

484. Xydis, Greece and the Great Powers, pp. 123-125.

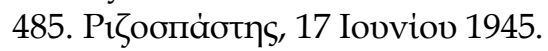

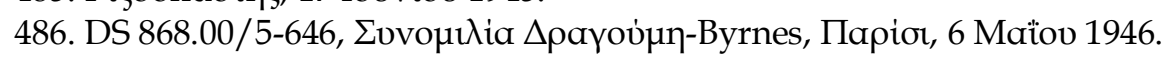

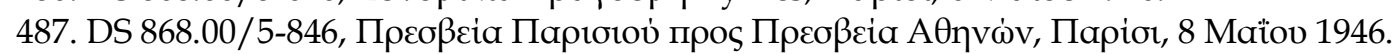

488. Byrnes, Speaking Frankly, p. 131. 
грчких претензија није била задовољена. На другом заседању, одржаном 27. јуна 1946. године, Грчка је добила Додеканез489.

Мировна конференција у Паризу одржана је од 29. јула до 11. октобра 1946. године. Грчка је затражила одштету у висини од 700 милиона долара од Бугарске, за штету коју је задобила за време бугарске окупације. Премијер Цалдарис је, поред обештећења, тражио и поновно разматрање грчко-бугарске границе и припајање Северног Епира, истичући да и Грчка има право да се заштити од евентуалних напада, као што су то урадиле Француска и СССР у случају Немачке ${ }^{490}$. Грчка страна је придала посебан значај стратешким питањима, не толико због територијалног проширења, колико због наде да ће САД и Британија препознати заједничку одбрамбену корист. Грчка влада је имала своје спољнополитичке циљеве, нарочито по питању националних претензија, и није придавала значај указивањима са енглеске и америчке стране. САД су, иако су водиле одлучнију политику у односу на Велику Британију што се тиче питања територијалног интегритета Грчке, затражили ограничење грчких територијалних претензија да би се избегао конфликт између великих сила.

Тако је, у једном разговору Бернса са Цалдарисом, вођеном 19. августа, грчки премијер га је упитао да ли ће САД, као њен савезник и пријатељ, подржати њене територијалне претензије. Бернс је одговорио да још нису одлучили, али да пре свега није за премештај становништва из друштвених и хуманитарних разлога. Додао је још да Грчка може да се обезбеди своју заштићеност у Уједињеним нацијама, а не припајањем нових територија ${ }^{491}$. Сличан је био и британски став, што Грцима није

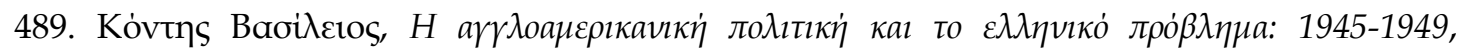

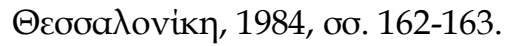

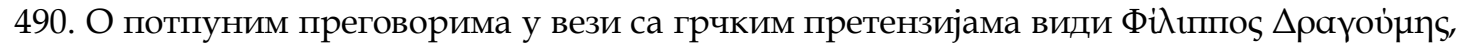

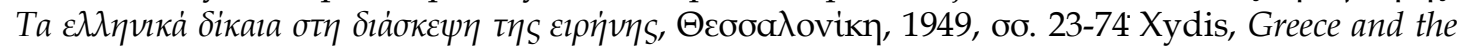
Great Powers, pp. 270-286, 319-335..

491. U.S. Department of State, Foreign Relations of the United States 1946, Paris Peace

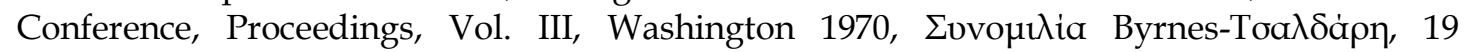
Avүoúøtov 1946, бб. 256-257. 
остављало никакве шансе за успех ${ }^{492}$. Американци и Британци, иако су били спремни да помогну Грчкој у нападима од стране комуниста, нису били спремни да јој помогну у њеним територијалним претензијама. На мировној конференцији Грчка влада је инсистирала на својим претензијама. Филипос Драгумис је, 30. августа 1946. године, затражио да се на следећем заседању Савета стави на дневни ред грчки план решавања питања Северног Епира. Совјетски и југословенски представници су се успротивили грчком захтеву, док су Џејмс Бернс и Ернест Бевин инсистирали да Грчка, као и сваки други представник, има право да представи свој случај ${ }^{493}$. Савет је прихватио грчки захтев са 12 гласова за, 7 против и 2 уздржана ${ }^{494}$.

Средином септембра било је јасно да ниједна од грчких претензија неће имати подршку САД-а, које да би избегли совјетску реакцију, нису биле спремне да подрже такве претензије. Према Драгумису, САД су биле вољне да подрже Грчку у процедуралном смислу, али не и суштински. САД нису хтеле да направе расцеп између четири велике силе и да доведу у питање успех Савета, само због задовољавања грчких интереса ${ }^{495}$.

Грчки представници састали су се са Бернсом, министром Иностраних послова САД-а, 1. октобра 1946. године. На овом састанку министар је изјавио да су САД врло пријатељски расположени према Грчкој и да ће урадити све у њиховој моћи да јој помогну, али да Грчка мора да буде свесна шта САД могу или не могу да ураде. Бернс је појаснио грчким изасланицима да Америчка влада не може да подржи грчке претензије на Мировној конференцији, али да ће радо покренути то питање на Савету министара Иностраних послова 496.

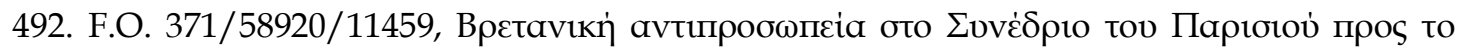

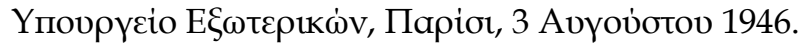

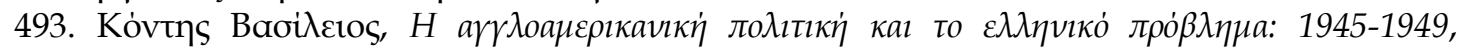

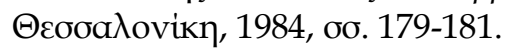

494. FR: 1946 III, p. 321 Cassidy, Paris Peace Conference, pp. 913-915.

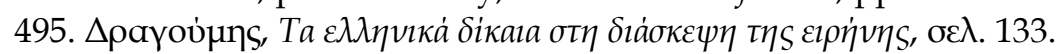

496. FR: 1946 III, pp. 614-615. 
Бернсов став је био да ће урадити све што је могуће да помогне Грчкој у економском погледу, али не може да подржи њене националне претензије. Сваки пут кад би грчки представници тражили америчку подршку, увек би добијали исти одговор, а то је да се сигурност Грчке остварује у Уједињеним нацијама, а не територијалним проширењем. САД су гледале са разумевањем и симпатијама на грчке аргументе за територијално проширење, и схватали су њено разочарење због не остваривања својих циљева, али су сматрали да због дугорочног мира и стабилности на Балкану, требају да подрже враћање на границе из 1939. године. И поред овога, Американци су нагласили Грчкој влади да ће је подржати, ако би се којим случајем десио било какав покушај промене граница Грчке од стране њених суседа или великих сила ${ }^{497}$.

Мировна конференција у Паризу се завршила 15. октобра 1946. године. На њој нису одбијене грчке националне претензије, већ су преусмерене на Савету министара Иностраних послова. Грчка влада је, и поред неуспеха на париској Мировној конференцији, одлучила да промовише своје националне претензије на Савету министара Иностраних послова. Премијер Цалдарис је упитао Стејт Дипартмент који ће бити став Америчке владе у вези са грчким национланим претензијама. Американци су одговорили да, у циљу остваривања мира на Балкану, не могу да подрже територијалне претензије Грчке. Грчка је требала да схвати америчку позицију и да не потеже питање својих националних претензија на Савету министара Иностраних послова. То би, у великој мери, допринело стварању једне стабилније ситуације на Балкану и довело би САД у бољу позицију да може да помогне Грчкој у свим егзистенцијалним питањима ${ }^{498}$.

Грчка влада је, оглушујући се на америчке препоруке, затражила од Савета министара у Њујорку да преиспита грчке националне претензије. Савет је преиспитао члан 1. Бугарског мировног споразума, 
11. новембра 1946. године. Ернест Бевин је предложио мале промене на грчко-бугарској граници (много мање од оних које је тражила Грчка), које је повукао кад је Џејмс Бернс одбио да их подржи, а Молотов одбио да расправља на ту тему 499 .

И поред тога, Савет министара Иностраних послова је, 3. децембра 1946. године, одлучио да бугарска граница треба да остане као што је била 1. јануара 1941. године, и да ће Грчка од Италије и Бугарске добити 150 милиона долара, на име одштете ${ }^{500}$. Савет је овим затворио за стално питање преиспитивања грчко-бугарске границе. Са друге стране, питање јужних граница Албаније је остало отворено. Грчке претензије на штету Албаније си биле игнорисане и никад нису расправљане на Савету. Као резултат одлука Савета, у Грчкој је владао осећај неправде и разочарења. Грчки народ није могао да верује да један верни савезник неће бити награђен, док ће Бугарска добити одштету за своју нелојалност у току рата. Таква одлука, по мишљењу Грчке владе, не само да неће довести до толико жељеног мира на Балкану, већ да ће само охрабрити агресивну политику Бугарске владе $\mathrm{e}^{501}$.

Грчка влада није успела, у великој мери, да оствари своје националне претензије. То се десило углавном из разлога што није успела да добро припреми теме које су је се тицале, и јер је очекивала да ће бити награђена за своје храбре услуге које је пружила током рата. Другим речима, заснивала је своју тактику на карти „херојског савезника“. Није увидела, међутим, да национални интереси Велике Британије и САД-а се не поклапају са том политиком. Изузев теме националних претензија, Америчка влада уложила је велики труд у Паризу и Уједињеним нацијама да покаже своју подршку Грчкој. Као што је изјавио и Бернс лидерима опозиције ${ }^{502}$, Американци су сматрали

499. European Peace Treaties, After World War II, New York, 1954, p. 87.

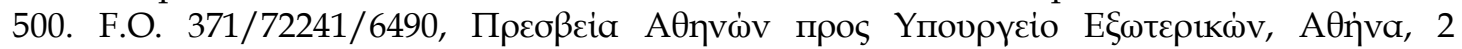
Апри入iov 1948 кaı Xydis, Greece and the Great Powers, pp. 419-420.

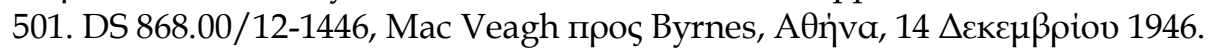

502. Бернс се састао са Г. Пападреуом, С. Венизелосем, П. Канелопулосом, Н. Зервасом и К. Рендисом 7. октобра 
да је ствар принципа да подрже грчке представнике сваки пут кад је то било могуће, посебно кад су се налазили под нападом источног блока ${ }^{503}$. Грчка није имала велику подршку од стране Британије. Разлог за то се вероватно може наћи у томе да кад год би неки грчки предлог долазио на дневни ред Савета, изражавали су се ставови како је јака демократија у Албанији, Бугарској и Југославији, насупрот грчком реактивизму и британском империјализму. У таквој атмосфери, Британци су одлучили да остану изван сваких преговора и да препусте иницијативу САД-у504.

Грчка је, у покушају да постигне своје територијалне претензије, водила једну самосталну спољну политику, чак и кад је САД и Британија нису подржавали. Грчка је, као мала сила, могла да постигне само ограничене циљеве. Политика САД-а и Британије била је да да заустави грчке претензије и да завлада на Балкану атмосфера мира.

Од грчких територијалних претензија, само је Додеканез остварен. Припајање Северног Епира и поновно разграничавање са Бугарском у корист Грчке нису се успешно завршиле. Један разлог за то је тај што су Албанија и Бугарска уживале потпуну подршку СССР-а на Мировној конференцији која је одржана 25. априла 1946. године у Паризу. Други разлог је био тај што западне велике силе нису биле спремне да уђу у отворени сукоб са Совјетским савезом за рачун Грчке, нарочито када ни саме нису биле сигурне да би припајање Северног Епира и планинске зоне Бугарске, које је тражила Грчка и где је била насељена компактна мањина Помака, донело неку суштинску корист осим сатисфакције Грчке владе. Што се тиче Северног Епира, западне силе су цениле да би њено одузимање од Албаније, поред директног одбијања Совјетског Савеза да пристане на тако нешто, довело и до могућности да одржи своју независност и на тај начин би била лак плен за Југославију, а то су покушали да спрече по сваку цену. Касније се испоставило да једна

503. FR: 1946 III, pp. 686-687.

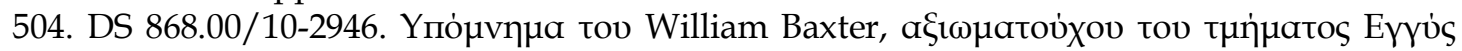

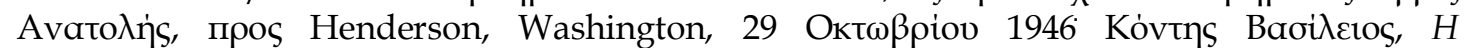

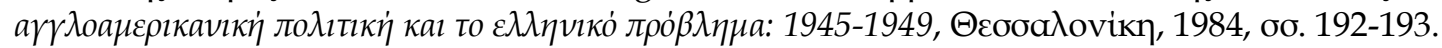


одржива Албанија представља мању опасност за сигурност Грчке, наспрам претње једне малене Албаније, која би била конфедеративни део једне велике и снажне Југославије. Поред тога, припајање бугарских територија на Родопију придало би постојећој муслиманској мањини у Западној Тракији неколико стотина хиљада муслиманских Помака, а можда и Петричи, једно од језгара најфанатичнијих бугарских присталица „аутономне“ Македоније. С друге стране, припајање Додеканеза, које је одлучено на савету министара Иностраних послова великих сила на Мировној конференцији 27. јуна 1946. године, донело је Грчкој веома важне стратешке и економске предности, и наравно територије и становништво, чија национална припадност није долазила у питање 505.

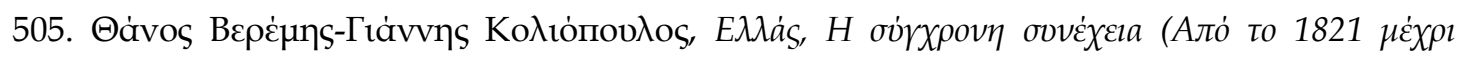

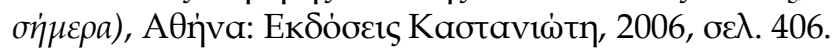




\section{ЗАКЉУЧАК}

Све три грчке владе које су формиране у избеглишттву у великој мери нису успеле да успешно спроведу у дело мисију које су преузели, а која се састојала од борбе свим расположивим средствима, олакшавање живота измученом народу у окупираној Грчкој и остварење националних територијалних претензија.

Позитивно деловање ових влада је било ограничено. Додела Додеканеза Грчкој несумљиво представља велики успех грчке владе. Треба напоменути да су Британци користили до задњег тренутка Додеканез као средство да наговоре Турску да уђе у рат. На исти начин су Британци поступили у случају Северног Епира, будући да тада још нису били одлучили о будућности нејаке Албаније. Они су грчку избегличку владу уверавали да ће се о територијалним питањима одлучивати након рата, рачунајући на њихову сагласност. Након проглашења независности Албаније, потпреседник владе П. Канелопулос је, исфрустриран политиком великог савезника, запретио оставком у случају да Енглеска не буде узела у обзир права Грчке. Овакав чврст став грчког вицепремијера је представљао непријатно изненађење за британско Министарство иностраних послова. Грчке избегличке владе нису успеле да се успешно суоче са питањем Кипра, из разлога што Велика Британија није хтела да одустане ни од најмањег дела њене империје.

Постоје унутрашњи и спољни чиниоци који су утицали на слабо функционисање избегличких влада. Међу унутрашњим чиниоцима спадају:

а) чињеница да грчке владе нису имале подршку великог дела грчког народа, насупрот другим избегличким владама. У грчким владама, посебно у владама Цудероса и Венизелоса, нису учествовале све политичке партије, са резултатом да није постојала заједничка политика, већ су преовладавале несугласице између партија и владе. Ови сукоби, 
који су имали јак елемент раздора с циљем освајања власти у ратном периоду, превазићени су крајем 1943. године уз помоћ британске владе. Влада националног јединства, која је формирана у Либији, сматрала се успехом, јер су у Папандреуовој влади учествовале све политичке снаге Грчке.

б) улога Краља и његова подршка диктаторском режиму од 4. августа, резултирала је губитком поверења народа у Георгиоса II. Приврженост монархији је пољуљана чак и у традиционално краљевски настројеним политичким круговима. Једини који су и даље сматрали монархију као једино решење за будуће државно уређење били су Британци, али само из разлога да би осигурали своје интересе.

г) политичка зависност краља Георгиоса II и грчких влада од Велике Британије. Грчке владе у избеглиштву, које су биле без народне подршке и уставно-правног легитимитета, сматрале су да је подршка Велике Британије једини начин да осигурају свој повратак у Грчку. На тај начин су минимализоване могућности преговарања, промене ставова и претензија са британском владом.

Под спољним чиниоцима се убрајају:

а) ограничавајући правни режим који је владао за све избегличке владе за време рата, који је повезивао њихов легитимитет са признањем од стране државе у којој би они пребивали. Ова чињеница је у великом степену ограничавала могућности било какве самосталне активности избегличких влада.

б) зависност избегличких влада у материјалном, техничком и економском смислу од Велике Британије. Економсак зависност, са свим својим пратећим појавама, је вероватно била неизбежна, узевши у обзир недостатак средстава грчке владе која ју је одвела у задуживање од Велике Британије и САД-а. Међутим, треба поменути и то да се грчка избегличка влада није побринула да обезбеди алтернативне изворе за покривање својим материјалних и технолошких потреба. Карактеристичан је детаљ да је препустила монопол комуникација са 
Грчком Великој Британији, са резултатом да грчка избегличка влада нема праву слику о ситуацији која влада у земљи. Изгубила је прилику да драстичније утиче на развој догађаја, када је одбила понуду Американаца преко Донована на Криту за стварање још једног канала комуникације. Насупрот овоме, остале избегличке владе су се грчевито бориле са британском владом у настојању да обезбеде контролу над комуникацијама са својим домовинама, као што је то урадила Јовановићева влада супростављајући се COE-у и Интелиџенс Сервису, ризикујући на тај начин подршку Велике Британије.

г) Стање ствари на међународној политичкој сцени. Тачније, Велика Британија је била одлучна да очува контролу на осетљивим областима Балкана и источног Средоземља, будући да је услед рата нафта добила јако пуно на значају и тако ставила првенствено Турску, али и Грчку, на листи области од виталног значаја за Велику Британију. За Черчила је најсигурније решење, за очување дугог и неометаног утицаја његове земље на овом подручју, био повратак краља Георгиоса II.

У настојањима Велике Британије да задржи Грчку под своју утицајну сферу, у суштини нису реаговале ни СССР, ни САД. Нарочито СССР, иако је могао да искористи импресиван раст комунизма у Грчкој, у неким тренуцима је ову чињеницу потпуно стављао по страни, а у неким другим је то користио као средство притиска како би осигурао свој утицај над другим, за њих значајнијим, земљама као што су биле Румунија и Пољска. Све ово се дешавало у оквирима споразума са Великом Британијом, којим су практично прихватили британску контролу над Грчком.

Што се тиче САД-а, трећег великог савезника, оне су од самог почетка дали сагласност за британску превласт у региону. Свакако у том тренутку није имала никакве намере активног мешања у дешавања на Балкану. Задовољила се улогом посматрача и није се мешала у унутрашња дешавања у Грчкој због јаког грчко-америчког лобија. Насупрот томе, председник Рузвелт, пркосећи либералној америчкој 
традицији, већини Американаца грчког порекла и самом Стејт Департменту, подржавао је повратак Георгиоса II на престо.

Према горе наведеним чињеницама, да се закључити да је тадашња ситуација на међународној политичкој сцени није остављала пуно простора за преокрет и избор. И поред тога, грчка избегличка влада је могла да врши много аутономнију политику у остваривању својих националних циљева. Примера ради, грчка влада је у сарадњи са САД-ом могла да боље искористи предности своје трговачке флоте, на коју је претендовала и Велика Британија. У складу са тиме, југословенска избегличка влада се приближила САД-у како би смањила британски притисак усмерен одстрањивању Махајловића из владе. Из тог разлога је преместила у САД део свог министарског савета и покренула југословенску дијаспору. Грчке владе у избеглиштву су одустале од било какве могућности преокрета које су имале, и практично предале своју будућност у руке Британца. 


\section{ИЗВОРИ И ЛИТЕРАТУРА}

\section{I. НЕОБЈАВЉЕНИ ИЗВОРИ}

1. Архив Србије и Црне Горе (Југославије), 103, Ф 54, бр. 258, Емигрантска Влада К.J. 1941-1945, Албанија 1941 и 103, Ф 56, бр. 267, Емигрантска Влада К.J. 1941-1945, Грчка 1942.

2. Архив Србије и Црне Горе (Југославије), 103, Ф 54, бр. 260, Споразум о Балканској Унији између Краљевине Југославије и Краљевине Грчке.

3. Архив Србије и Црне Горе (Југославије), 103, Ф 54, бр. 260, Споразум између Краљевине Југославије и Краљевине Грчке о Установљену Балканске Уније.

4. Архив Србије и Црне Горе (Југославије), 103, Ф 54, бр. 260, Agreement between The Kingdom of Yugoslavia and The Kingdom of Greece concerning the Constitution of The Balkan Union.

5. Архив Србије и Црне Горе (Југославије), 103, Ф 54, бр. 260, нацерт Грчко-југословенског Споразума 15. јануара 1942. године.

6. Архив Србије и Црне Горе (Југославије), 103, Ф 54, бр. 260, Address delivered by his Majesty The King of The Hellenes at a luncheon given by the greek government at the Dorchester hotel, London in honour of his Majesty The King of Yugoslavia and the yugoslav government on Thursday, January $15,1942$.

7. Архив Србије и Црне Горе (Југославије), 103, Ф 54, бр. 260, шифрован телеграм Фотића, пов. бр. 10, отправљен из Вашингтона 5. јануара 1942. године у 13.26 часова и примљен у Лондону 6. јануара 1942. године у 10.00 часова.

8. Архив Србије и Црне Горе (Југославије), 103, Ф 54, бр. 260, парафраза Фотића, бр. 20, Вашингтон, 6. јануара 1942. године.

9. Архив Србије и Црне Горе (Југославије), 370, Ф 25, бр. 74, Посланство К.J. у Турској-Цариграду, Анкара 1919-1945, Бугарска 1944 и 370, Ф 27, бр. 28, Емигрантска Влада К.J. 1941-1945, Посланство К.J. у ТурскојЦариграду, Анкара 1919-1945, Грчка 1939-1945.

10. Архив Србије и Црне Горе (Југославије), 411, Ф 6, бр. 15, Генерални Конзулат К.J. у Цариграду, Бугарска 1942 и 103, Ф 55, бр. 262, Емигрантска Влада К.J. 1941-1945, Бугарска 1942. 
11. А.Ү.Е. (Архив Министарства спољних послова) 1941, А' По入ıтєкиं, 12,

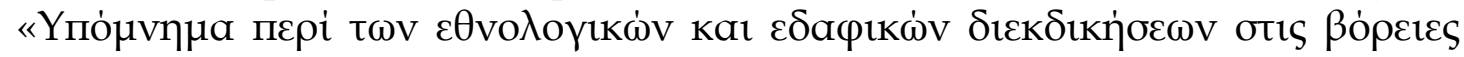

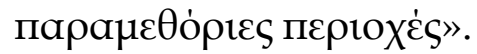

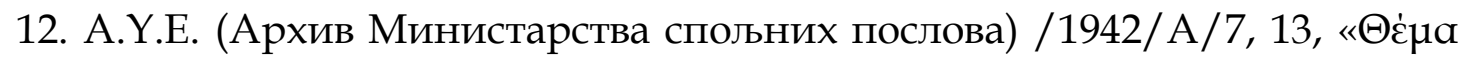

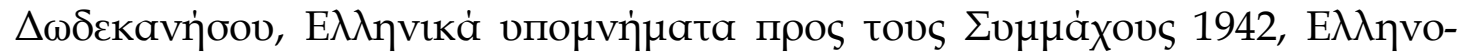

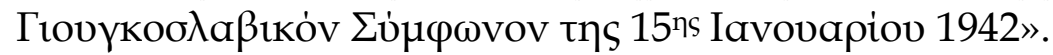

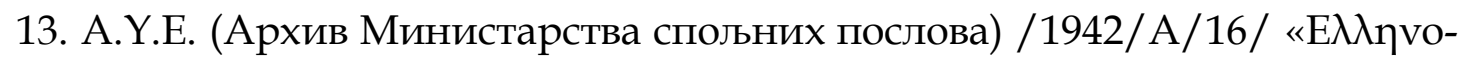

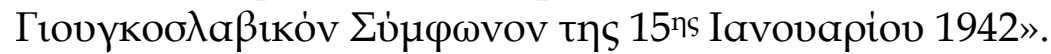

14. А.Ү.Е. (Архив Министарства спољних послова) /1942/А/16I/

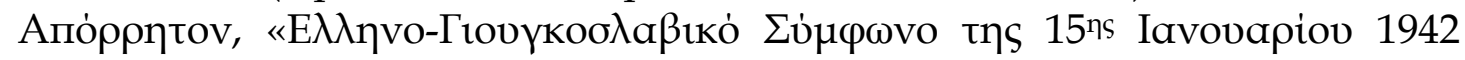

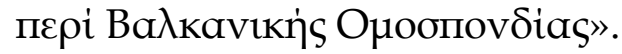

15. А.Y.Е. (Архив Министарства спољних послова) /1942/А/16/

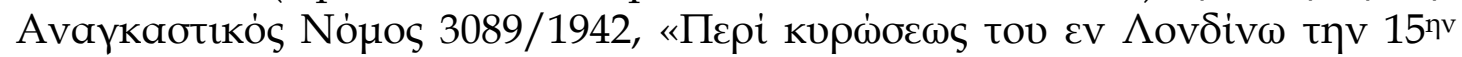

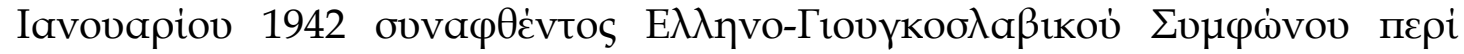

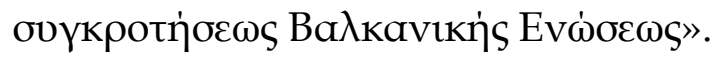

16. А.Ү.Е. (Архив Министарства спољних послова) /1942/А/16I/

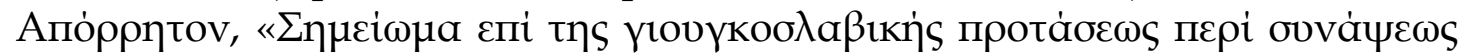

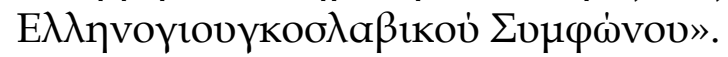

17. А.Ү.Е. (Архив Министарства спољних послова) /1942/А/16I/ Confidential «Memorandum», Washington, D. C, January 6, 1942.

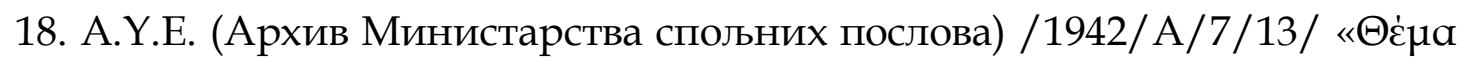

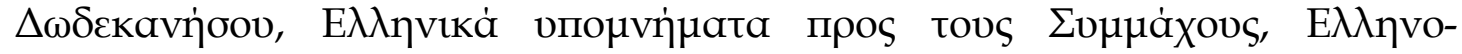

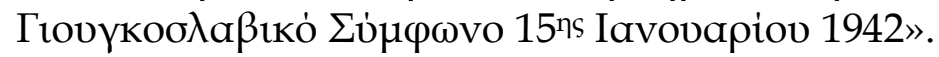

19. А.Y.Е. (Архив Министарства спољних послова) /1942/A/16/ Royal

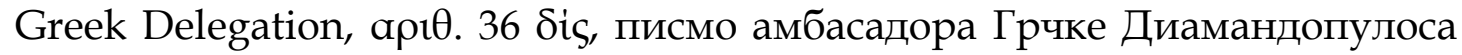
Краљевском Министарству спољних послова Грчке, Washington, 6. јануара 1942. године.

20. А.Ү.Е. (Архив Министарства спољних послова) /1942/А/16/

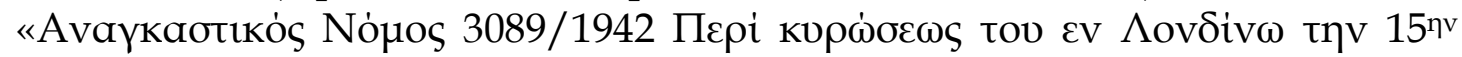

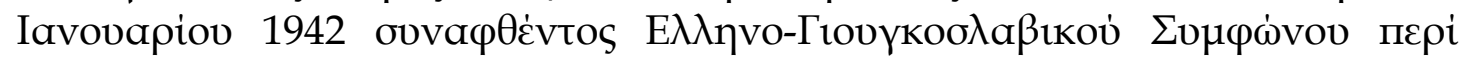

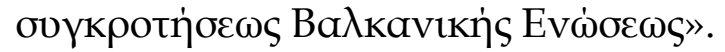

21. А.Ү.Е. (Архив Министарства спољних послова) /1942/А/16I/

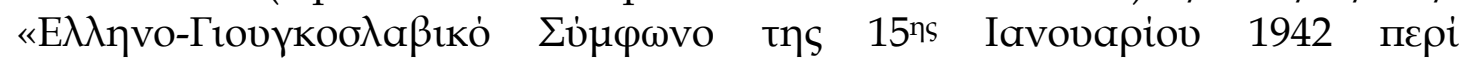

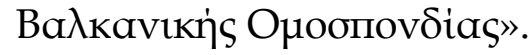


22. А.Y.Е. (Архив Министарства спољних послова) /1942/А/16I/

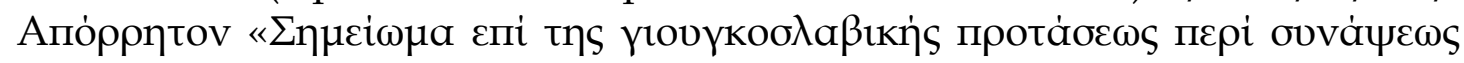

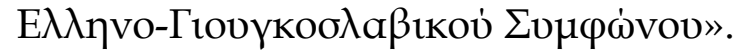

23. А.Y.Е. (Архив Министарства спољних послова) /1942/А/16I/ Confidential «Memorandum», Washington, D. C., January 6, 1942.

24. А.Ү.Е. (Архив Министарства спољних послова) /1942/8/ «Коßе́рvұоп

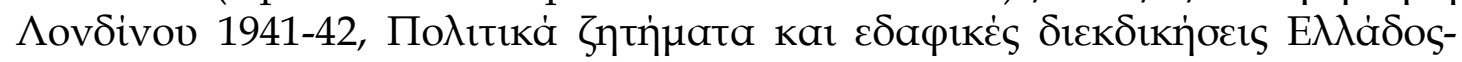

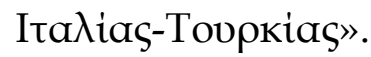

25. А.Ү.Е. (Архив Министарства спољних послова) /1943/А/9/II/20/

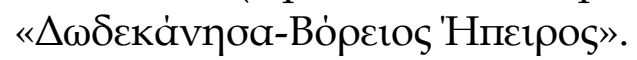

26. А.Ү.Е. (Архив Министарства спољних послова) /1944/12.5/ «Во́рєเо૬

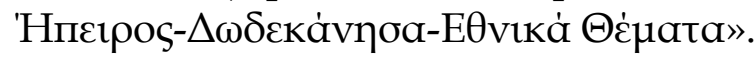

27. А.Ү.Е. (Архив Министарства спољних послова) /1944/14.3/

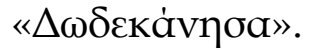

28. А.Ү.Е. (Архив Министарства спољних послова) Грарєіо Үфопоорүоن

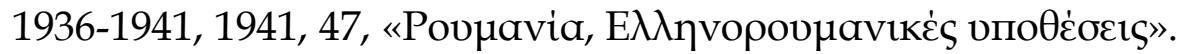

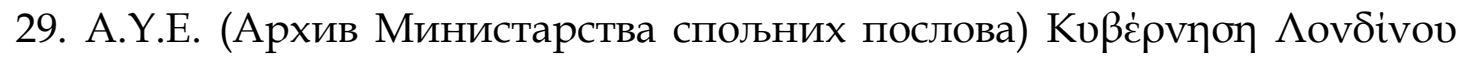

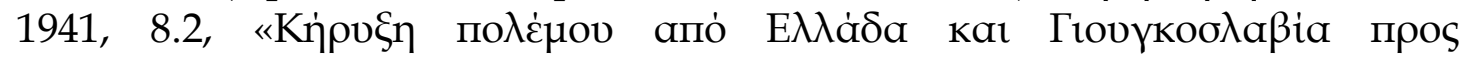
Bouגүapia».

30. А.Ү.Е. (Архив Министарства спољних послова) Коßе́рvұоп Кайроv

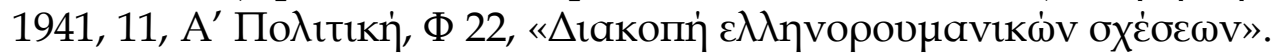

31. А.Ү.Е. (Архив Министарства спољних послова) Коßе́рvпоп Kайроv

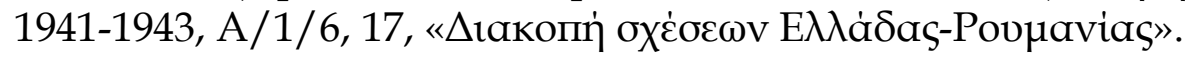

32. А.Y.Е. (Архив Министарства спољних послова) Коßе́рvпоп Kaїроv

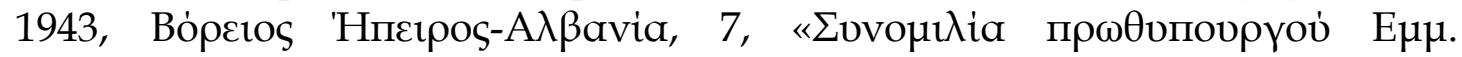

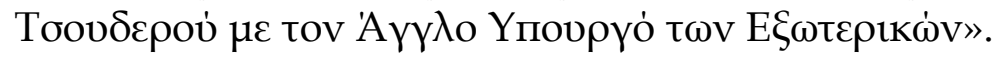

33. А.Ү.Е. (Архив Министарства спољних послова) Коßе́рvпоп Каїроv

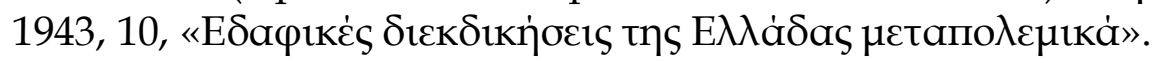

34. А.Ү.Е. (Архив Министарства спољних послова) Коßв́рvпоп Каїроv

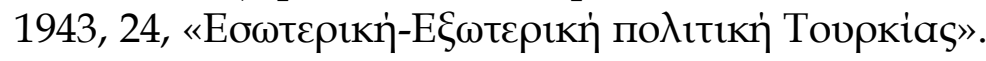

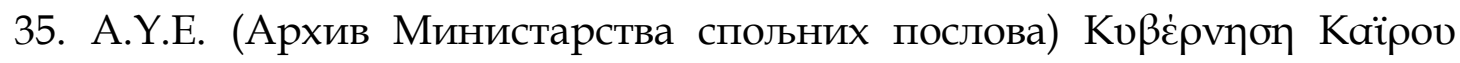
1944, III, 42.2, «Bou入 үapia». 
36. А.Ү.Е. (Архив Министарства спољних послова) Коßв́рvпоп Kaїроv

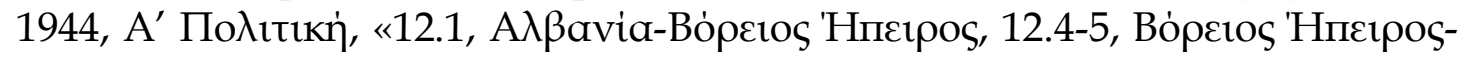

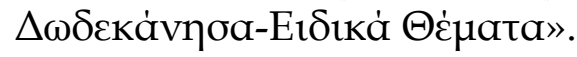

37. А.Ү.Е. (Архив Министарства спољних послова) Коßв́рvฤоп Каїроv 1944, A' По入ıтเкท่, 38.1, B/13.

38. А.Ү.Е. (Архив Министарства спољних послова) Коßє̇рvпоп Каїроv

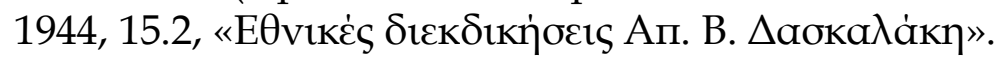

39. А.Ү.Е. (Архив Министарства спољних послова) Коßв́рvпоп Kаїроv

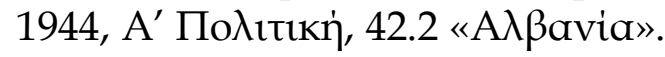

40. А.Ү.Е. (Архив Министарства спољних послова) Коßє̇рvпоп Кайроv

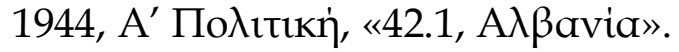

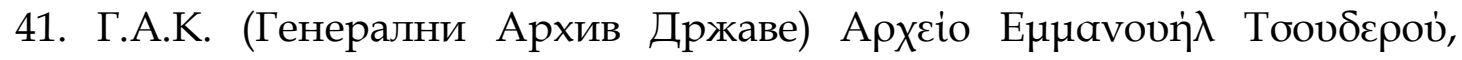
Апоото入иं $\Delta^{\prime}, \varphi 6$.

42. Архив Цудероса у библиотеци Генадије у Атини.

43. Архив Цудероса у Генералном архиву државе у Атини.

44. Дневник Цудероса у библиотеци Генадије у Атини.

45. FOREIGN OFFICE PAPERS (F.O. 371)

\section{II. ОБЈАВЉЕНИ ИЗВОРИ}

1. Богдан Кризман, Југословенске владе у избјеглиштву 1941-1943

(Документи), Загреб: Глобус (Архив Југославије), 1981.

2. Бранко Петрановић, Југословенске владе у избеглиштву 1943-1945

(Документи), Загреб: Глобус (Архив Југославије), 1981.

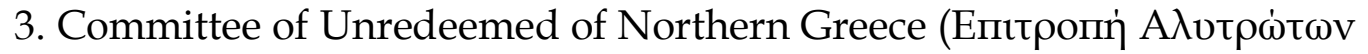

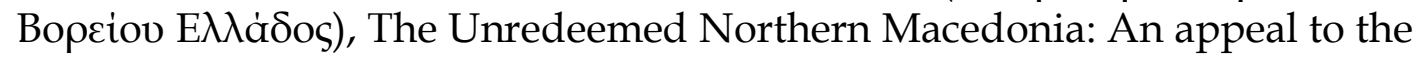
Democratic Peoples of the United Nations, Allies of Hellenism during the Last War, Thessaloniki, 1946

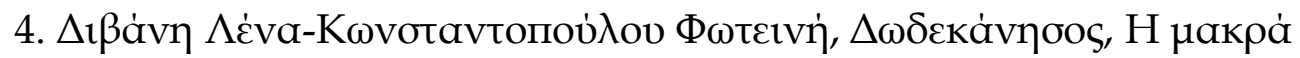

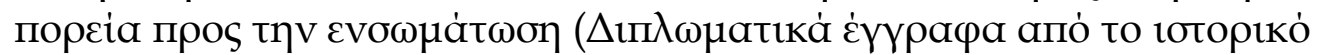

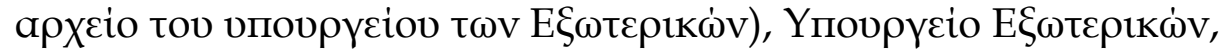

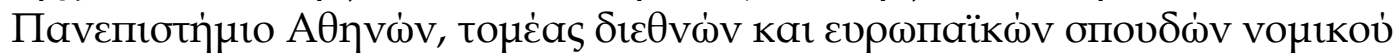




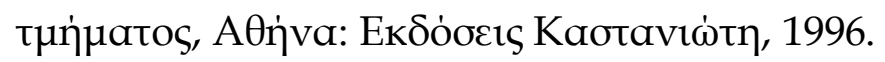

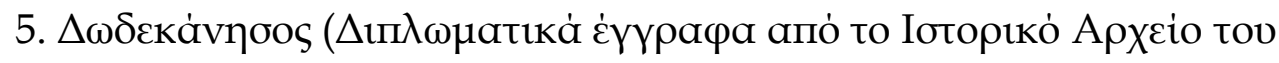

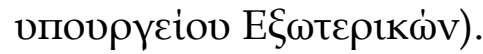

6. Dragoumis Papers, file 67.1, doc. 4 dated 9 May 1945.

7. Dragoumis Papers, file 67.3, doc. 38, Aristotelis Matlis to Dragoumis, 24 Feb. 1945.

8. Dragoumis Papers, file 67.3, doc. 40, Aristotelis Matlis to Dragoumis, 3 July 1945, Apostolos Poulopoulos, Chairman of the Chamber of Commerce and Industry of Athens to Dragoumis, 15 Nov. 1945, doc. 47, Theodoros Oikonomou, Chairman of the Thessaloniki Bar Association to Dragoumis, 2 Jan. 1945.

9. Dragoumis Papers, file 67.4, docs. 48-55, Daily bulletin of the First Congress of National Rights, Thessaloniki, 25 Oct.-1 Nov. 1945.

10. Dragoumis Papers, file 68.1, doc. 13, Alexandros Kirou to Michael Tsamados, Under-Secretary for Foreign Affairs, 12 May 1945, doc. 21, National Union of Northern Greeks: Epirotans-Thracians-Macedonians to Prime Minister Constantine Tsaldaris, 20 April 1946.

11. Dragoumis Papers, file 69.3, doc. 150, Committee of National

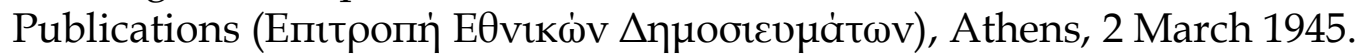

12. Dragoumis Papers, file 76.5, doc. 94, Dragoumis to the director of Ethnos (Athens Daily), 5 Nov. 1946.

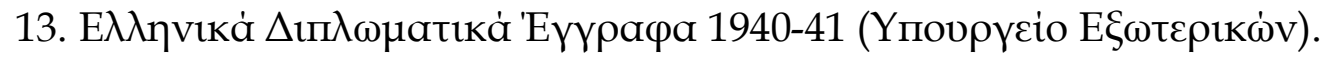

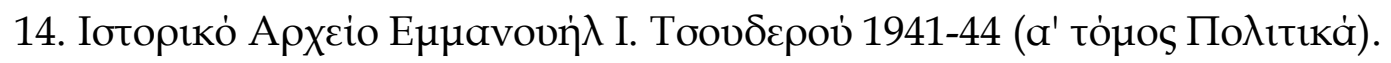

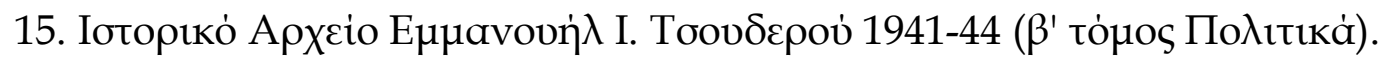

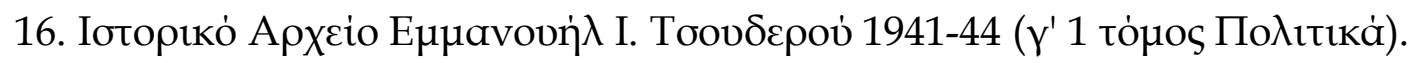

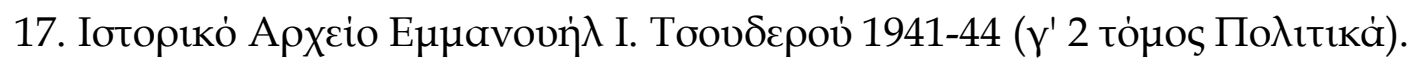

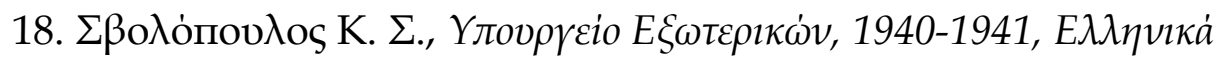

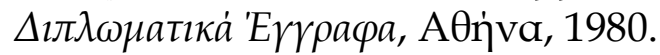

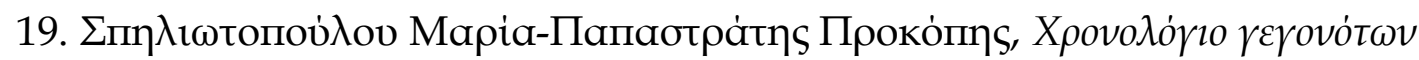

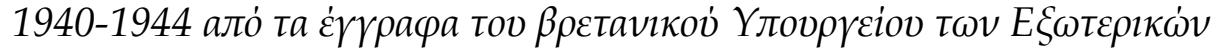

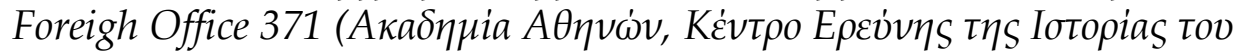




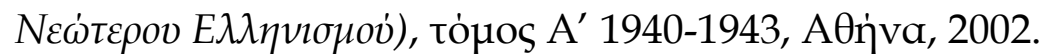

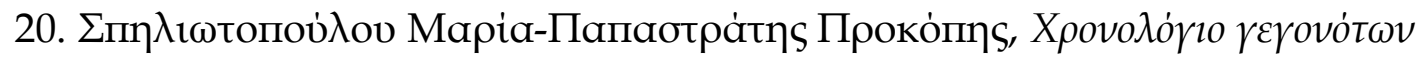

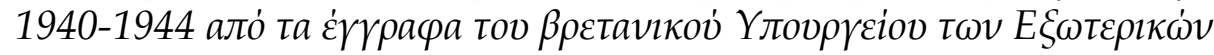

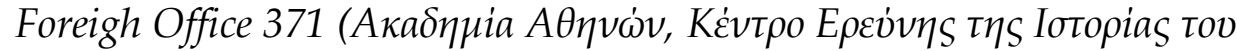

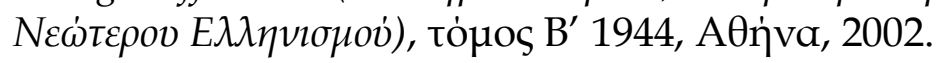

21. U.S. Department of State, Foreign Relations of the United States 1942, Vol. Europe.

22. U.S. Department of State, Foreign Relations of the United States 1946, Paris Peace Conference, Proceedings, Vol. III, Washington 1970.

23. U.S. Department of State, Foreign Relations of the United States 1944, Vol. V, Near East and Africa, Washington 1965.

24. European Peace Treaties, After World War II, New York, 1954.

\section{III. ШТАМПА}

1. Службене Новине Краљевине Југославије (Ратно издање), бр. 6-1, 30. априла 1942. године.

2. Eden Antony, The Memoirs of Antony Eden: The Reckoning, London, 1965.

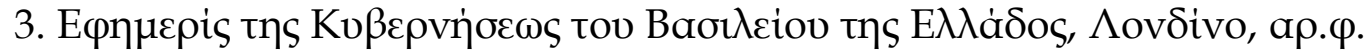

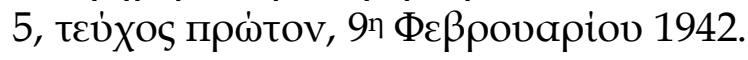

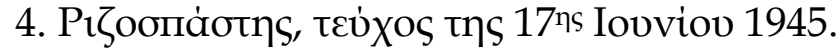

5. Светозар Вукмановић-Темпо, Револуција која тече, Мемоари (трећа књига), Загреб: Глобус, 1982.

6. Cordell Hull, Memoirs, vol. 2, New York, 1948.

7. Cordell Hull, Memoirs of Cordell Hull, vol. I-II, Hodder and Stoughton, London, 1948. 


\section{IV. ЧЛАНЦИ}

1. Alexandris Alexis, «Turkish Policy Towards Greece During the Second World War and its Impact on Greek-Turkish-Detente», Balkan Studies, vol. 23, no 1, 1982.

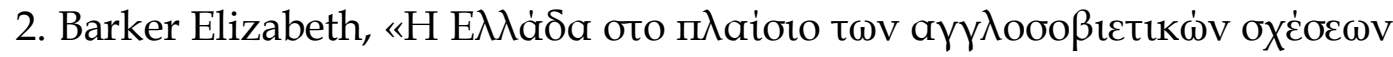

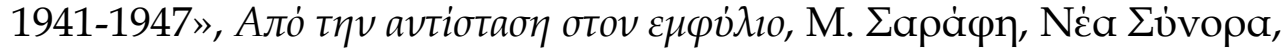
1982.

3. Vlanton E., «Documents: The OSS and the Greek-Americans» бто Journal of the Hellenic Diaspora, summer 1982, vol. IX, No 2.

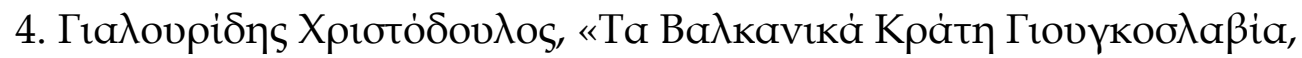

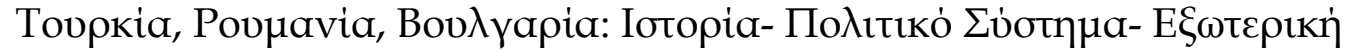

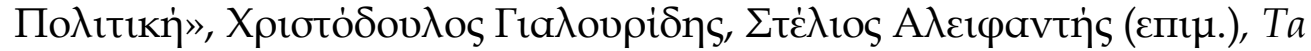

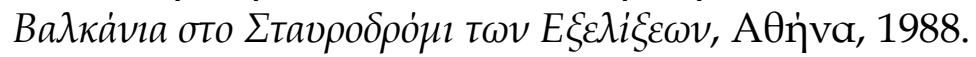

5. Clogg Richard, "Greek government in exile», International History Review, July 1979.

6. Dean Vera, «European Agreements for post-war reconstruction», oto Foreign policy reports, 18, 1942-43.

7. Dallek R., «A naïve attempt to end spheres of influence» oto The Roosevelt Diplomacy and World War II, Rinehart and Winstone, New York, 1970.

8. Deringil Selim, «The Preservation of Turkey's Neutrality During the Second World War: 1940», oto Middle Eastern Studies 18, 1982.

9. Exindaris G., «The position in Greece», International Affairs, April 1944.

10. Fisher-Galati Stephen, «Prelude to Communist Totalitarianism», Dinu C.

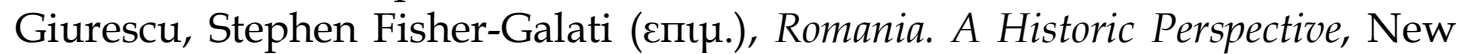
York, 1998.

11. Hoppe Hoans-Joachim, «Germany, Bulgaria, Greece: Their relations and Bulgarian policy in occupied Greece», Journal of the Hellenic Diaspora, Fall, Vol IX, No 3, 1984.

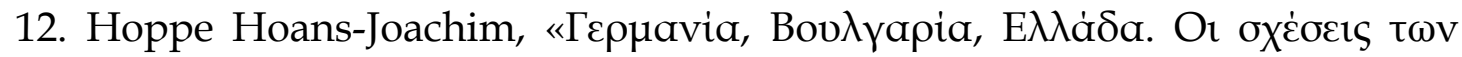

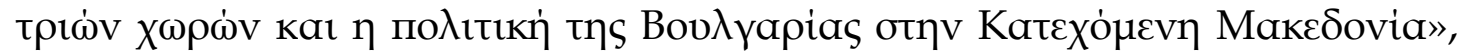

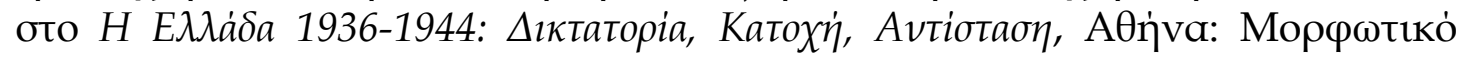
Ivoutoúto ATE, 1990. 
13. Kitroeff A., "Governments in Exile, Legal Succession and Related

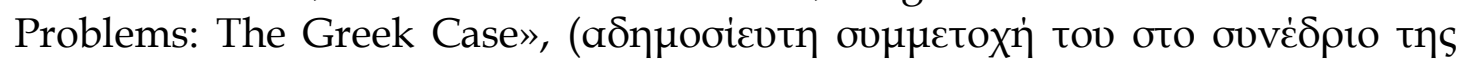
British International Studies Association), 1979.

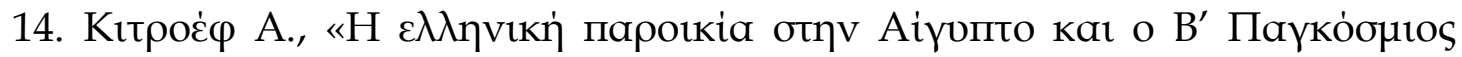

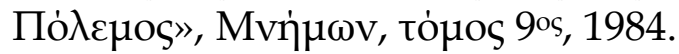

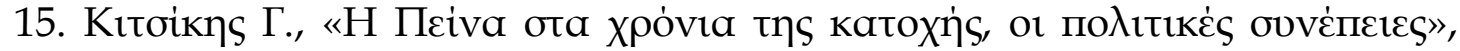

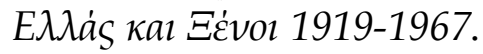

16. Kondis B., «Greek National Claims at the Paris Peace Conference of 1946», Balkan Studies, 32:2, 1991.

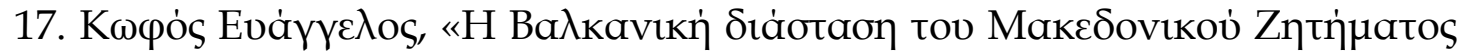

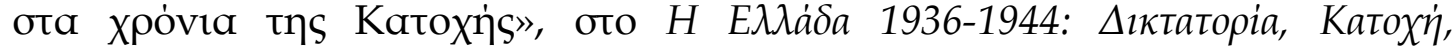

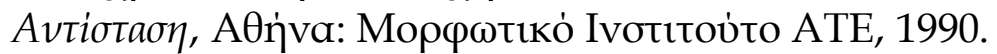

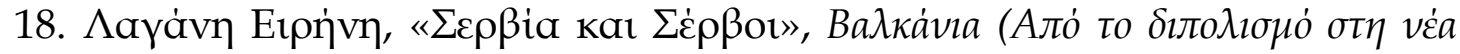

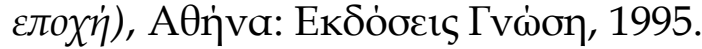

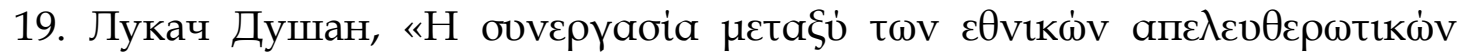

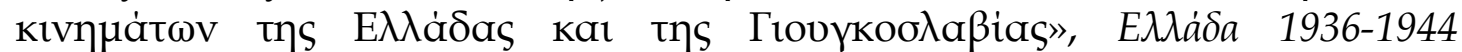

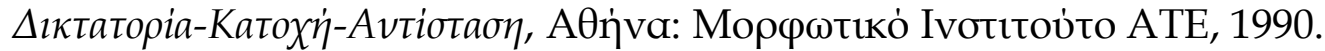

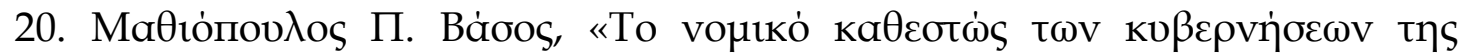

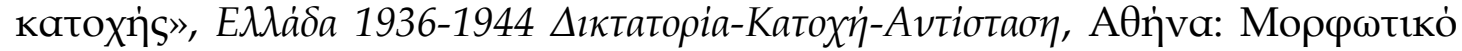
Ivotıтoúto ATE, 1990.

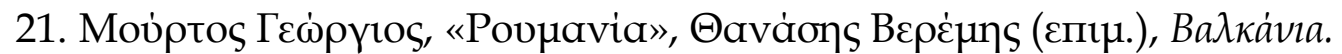

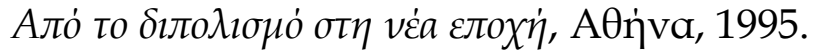

22. Oppenheimer F. E., «Governments and Authorities in Exile», The American Journal of International Law, October 1942.

23. Pavlowich S., Out of Context-The Yugoslav government in London 19411945, Journal of Contemporary History, London, Vol. 16, 1981.

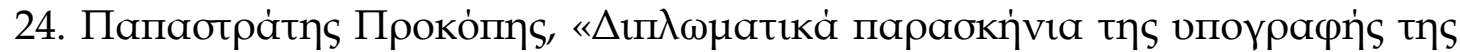

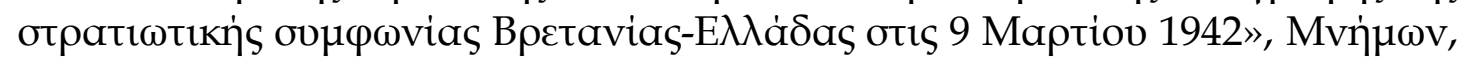
7os tónos.

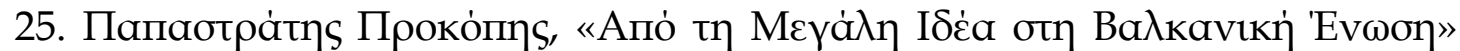

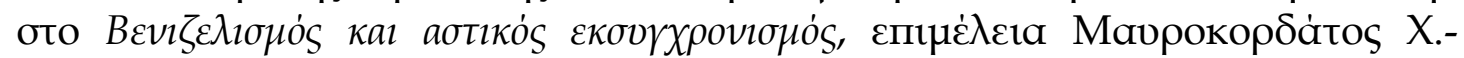

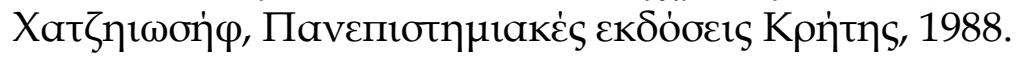




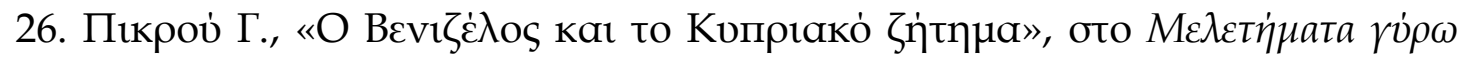

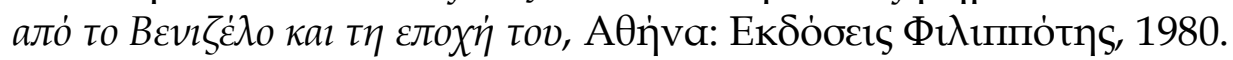

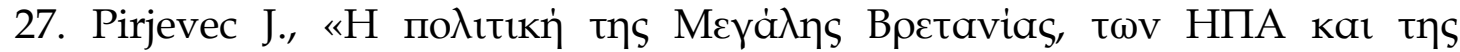

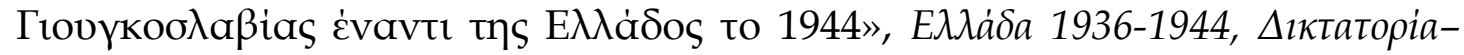

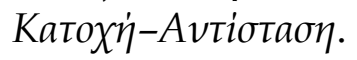

28. Rustow D. A., «Foreign Policy of the Turkish Republic» oto Makridis C. Roy, Foreign Policy in World Politics, Englewood Cliffs, 1959.

29. Svolopoulos C., "Anglo-Hellenic Talks on Cyprus during the Axis campaign against Greece» oto Balkan Studies, т. 23, v. 1, Thessaloniki, 1982.

30. Xydis Stephen, «The Secret Anglo-Soviet Agreement on the Balkans of October 9, 1944», Journal of Central European Affairs, vol. 15, 1995.

\section{V. ЛИТЕРАТУРА}

1. Alexandris Alexis, The Greek Minority in Istanbul and the Greek-Turkish relations 1918-1974, Athens, Center for Asia Minor Studies, 1983.

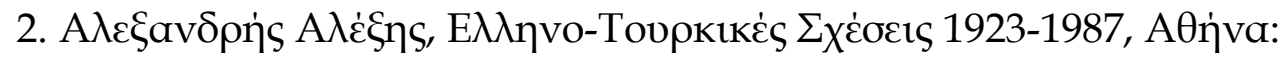

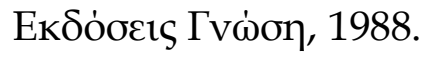

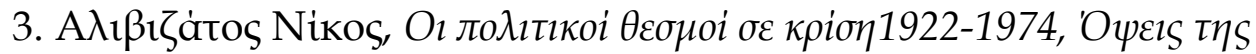

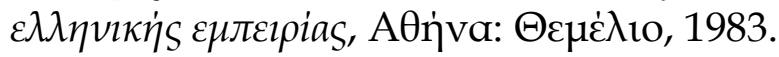

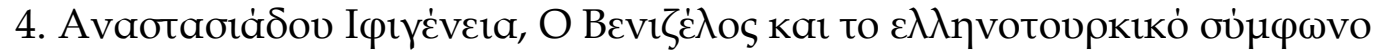

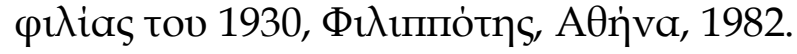

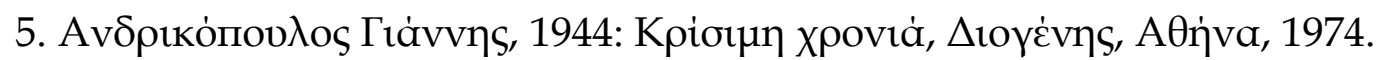

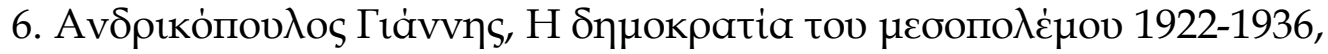

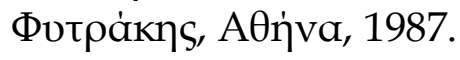

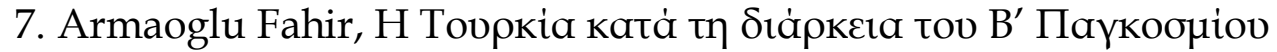

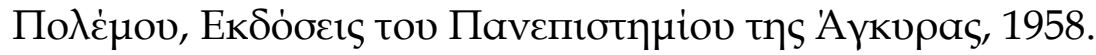

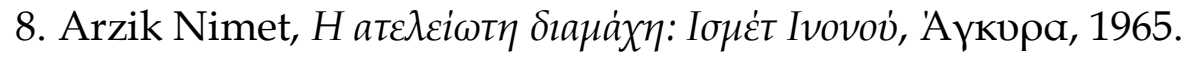

9. Ataov Turkkaya, Turkish Foreign Policy, 1939-1945, 'Аүкupa, 1965.

10. Аврамовски Живко, Балканска антанта (1934-1940), Институт за савремену историју, Београд, 1986. 
11. Barbulesku Ilia,

12. Barker Elizabeth, Macedonia: its Place in Balkan Power Politics, Royal Institute of International Affairs, 1950.

13. Barker Elizabeth, Британска политика на Балкану у II Свјетском рату, Загреб: Глобус, 1978.

14. Barros James, The Corfu incident of 1923, Princeton University Press, 1965.

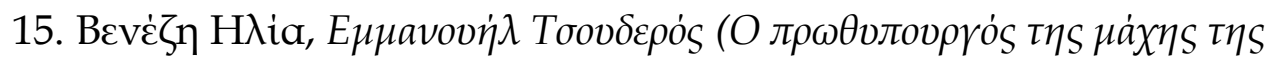

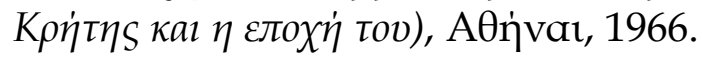

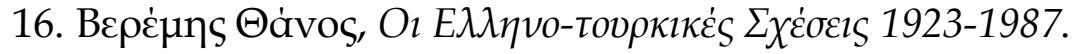

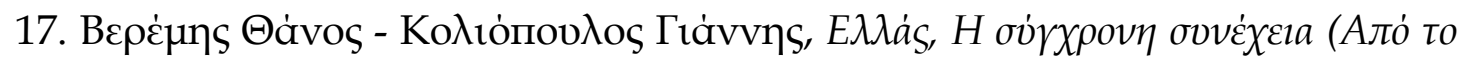

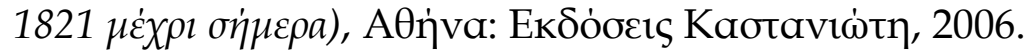

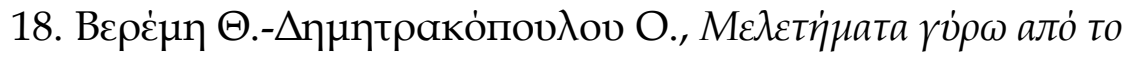

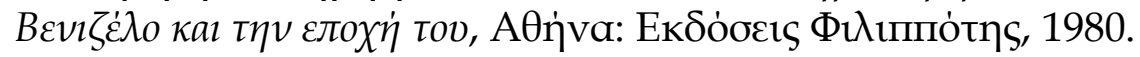

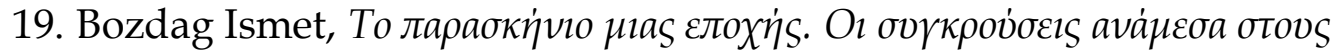

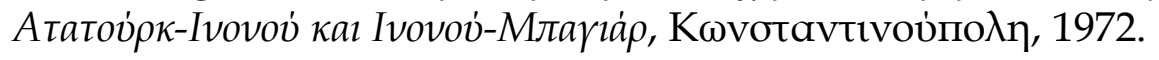

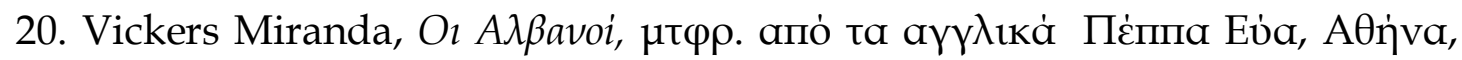
1997.

21. Virgilij G. Amadori,

22. Vlam Adam, Expansion and coexistence, the history of the Soviet foreign policy 1917-1967, Secker and Warburg, London, 1968.

23. Vojtech Mastny, Russia's Road to the Cold War: diplomacy, war-fare and the politics of communism 1941-1945, Columbia University Press, 1979.

24. Ђуретић Веселин, Влада на беспућу, Београд: Институт за савремену историју «Народна књига», 1982.

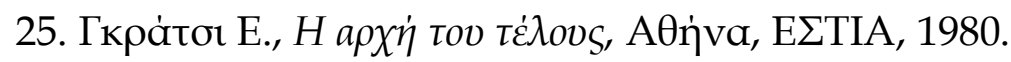

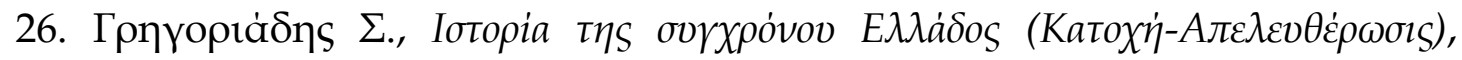
tónos $2^{\circ \text { os. }}$

27. Campus Eliza, The Little Entente and the Balcan Alliance, Biblioteka Historica

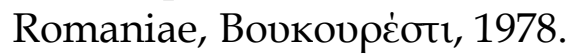


28. Castellan Georges, A History of the Romanians, New York, 1989.

29. Clayton G. D., Britain and the Eastern Question, Lion Library, London, 1971.

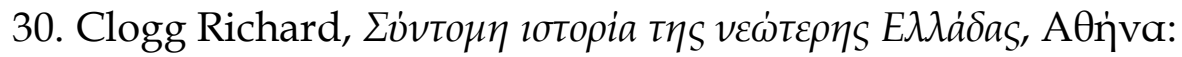

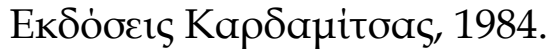

31. Clogg Richard, British Policy towards Wartime Resistance in Yugoslavia and Greece, Macmillan, London, 1975.

32. Close D. H., The Greek Civil War 1943-1950: Studies of Polarization, London: Routledge, 1993.

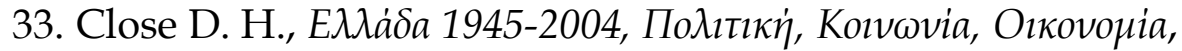

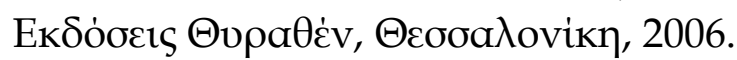

34. Constantopoulos D., The Paris Pease Conference of 1946 and the Greek-Bulgarian relations, Institute for Balkan Studies, Thessaloniki, 1956.

35. Coutouvidis J., Reynolds J., Poland 1939-1947, Leicester University Press, 1986.

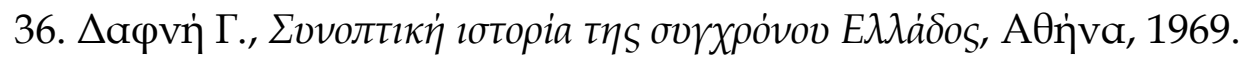

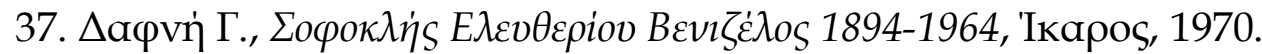

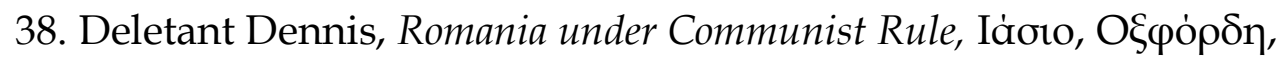
Пó

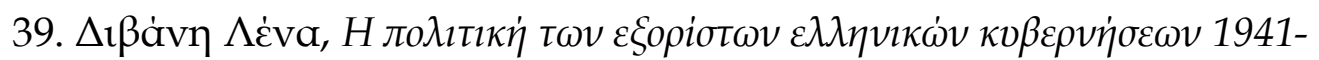

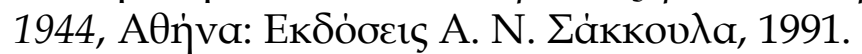

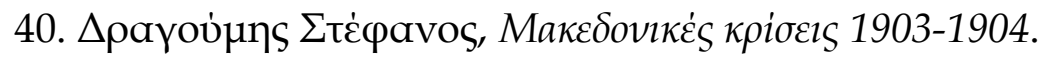

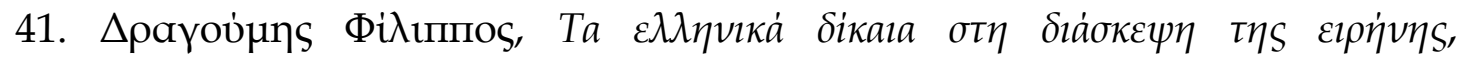

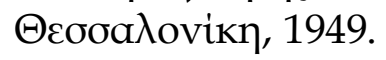

42. Giaffo Lou, Albania: Eye of the Balkan Vortex, 2000.

43. Giurescu C. Dinu, Romania's Communist Takeover: The Radescu Government, New York, 1994.

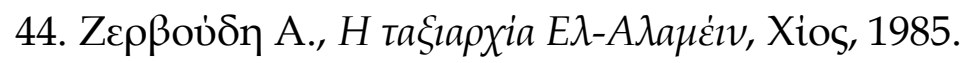




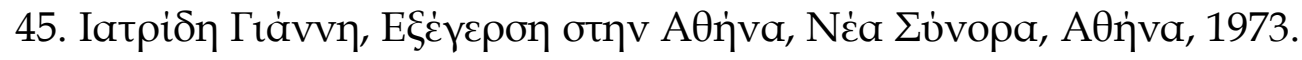

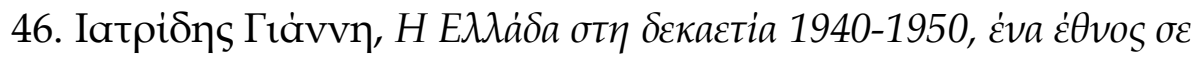

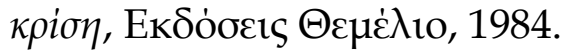

47. Iatrides John, Ambassador Mac Veagh Reports, Princeton University Press, 1980.

48. Iatrides John, Revolt in Athens. The Greek Communist "Second Round" 19441945, Princeton, Princeton University Press, 1972.

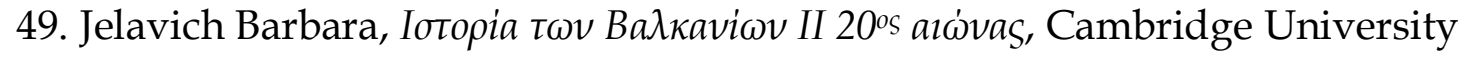
Press, 1983.

50. Judah Tim, The Serbs. History, Myth and the Destruction of Yugoslavia, London, 1997.

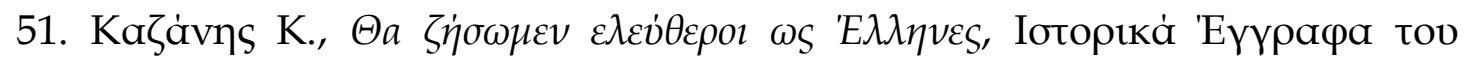

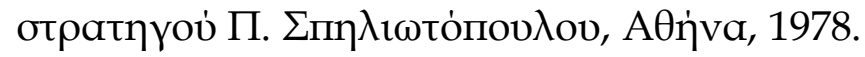

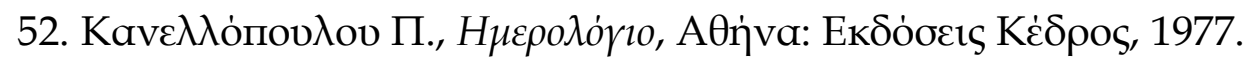

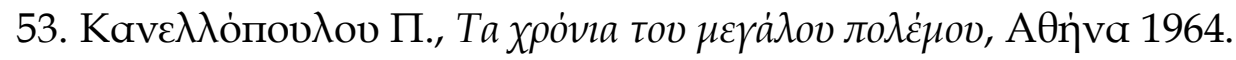

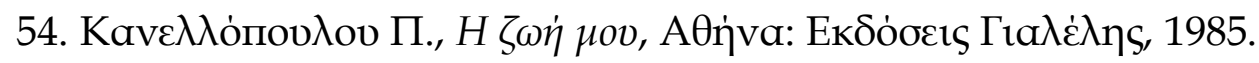

55. Kacewicz G., Great Britain, The Soviet Union and the Polish Government in Exile, Martinus Nijhoff Publishers, 1979.

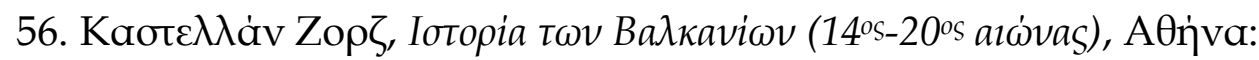

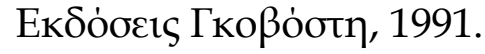

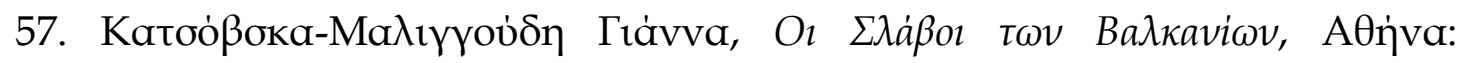

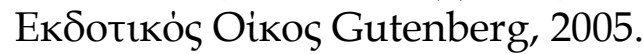

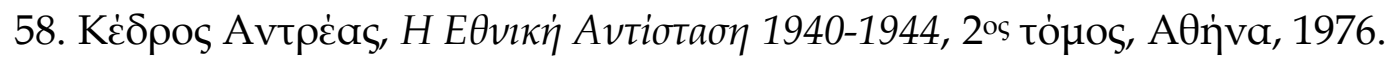

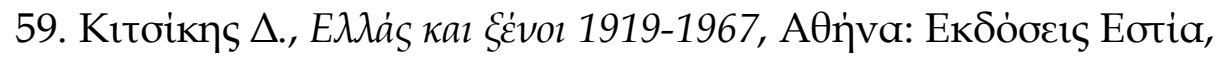
1977.

60. Клог Ричард, Историја Грчке новог доба, Београд: CLIO, 2000.

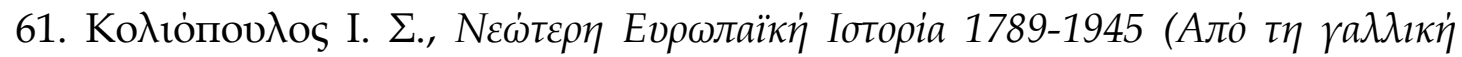

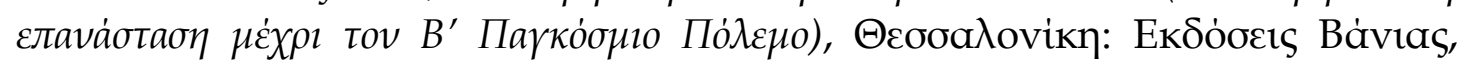
2000. 


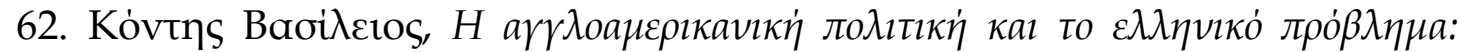

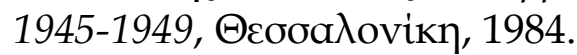

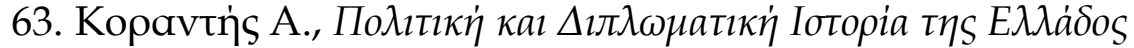
1941-1945.

64. Kofos E., Nationalism and Communism in Macedonia, Thessaloniki, 1964.

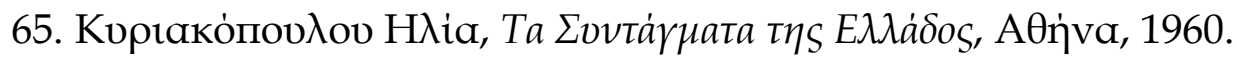

66. Lampe R. John, Yugoslavia as History. Twice there was a country, Cambridge, 2000.

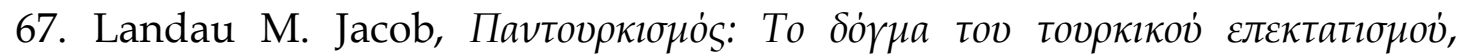
AӨn்va, 1985.

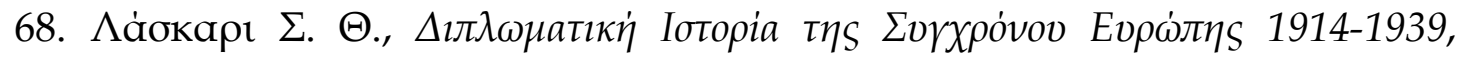

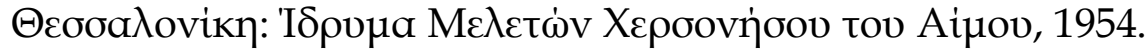

69. Leeper R., When Greek meets Greek, London, Chatto and Windus, 1950.

70. Марић Михајло, Краљ и Влада у Емиграцији, Загреб: Епоха, 1966.

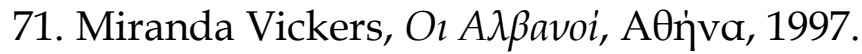

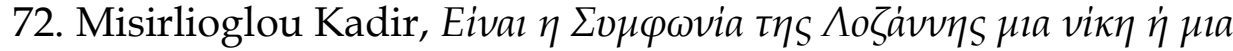

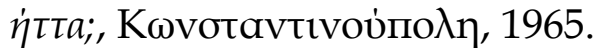

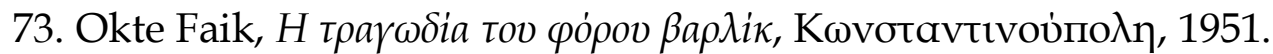

74. Павловић К. Стеван, Историја Балкана, Београд: CLIO, 2001.

75. Palmer S.-King R., Yugoslav Communism and the Macedonian question, Archon books, USA, 1971.

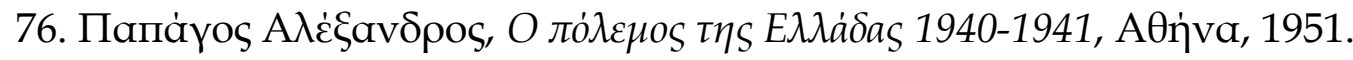

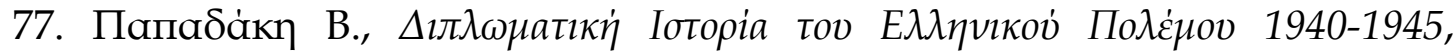
AӨn்va, 1956.

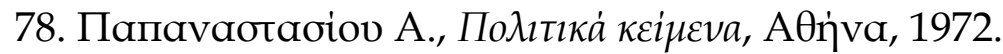

79. Papastratis Procopis, British policy towards Greece during the Second World War 1941-1944, Cambridge: Cambridge University Press. 
80. Петрановић Бранко, Балканска Федерација 1943-1948, Београд: ИКП Заслон, 1991.

81. Петрановић Бранко, Историја Југославије 1918-1978, Београд: Нолит, 1981.

82. Петрановић Бранко, Историја Југославије 1918-1988 (друга књига), Београд: Нолит, 1988.

83. Philon A., The Question of Northern Epirus, Washington, Greek office of information, 1945.

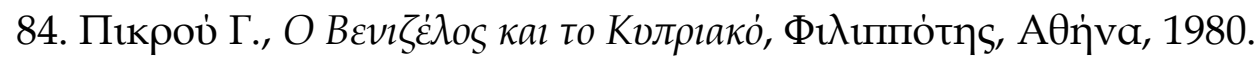

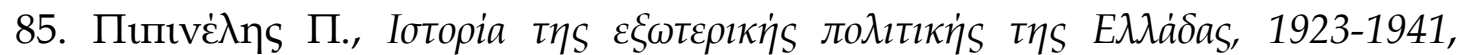

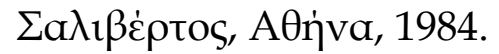

86. Pipinelis P., Europe and the Albanian question, Chicago, Argonaut, 1963.

87. Polonsky Antony, The Little Dictators, The History of Eastern Europe since 1918, Routledge and Kegan Paul, London, 1975.

88. Polonsky Antony, The Great Powers and the Polish Question, 1941-1945, L.S.E., 1976.

89. Ponomaryov B., A. Gromyko, V. Khvoston, History of Soviet foreign policy 1917-1945, Moscow, 1969.

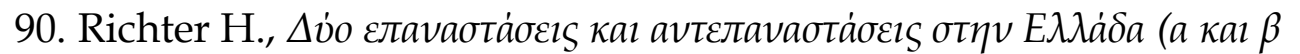

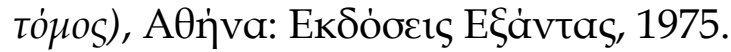

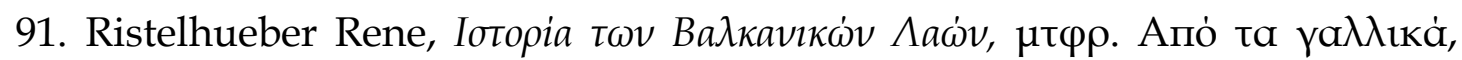

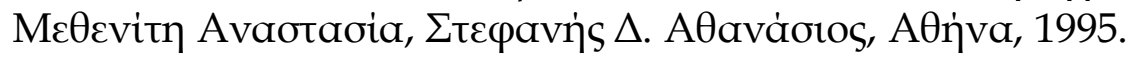

92. Ристовић Милан, Политички односи на Балкану 1941-1944 (У светлости извештаја југословенске амбасаде у Анкари), рукопис, Београд, 1981.

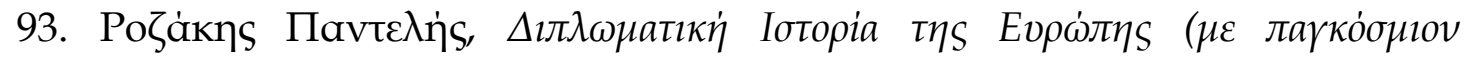

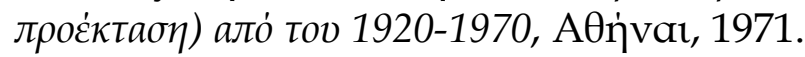

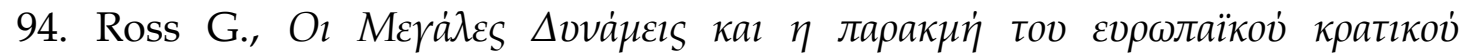

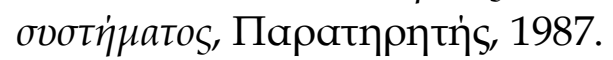

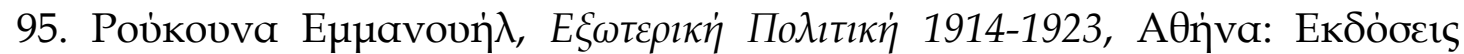

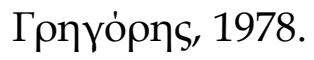




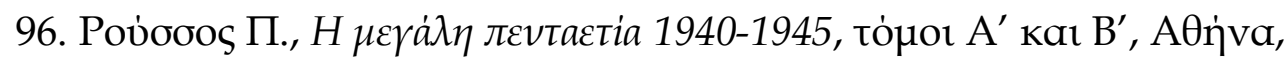
1982.

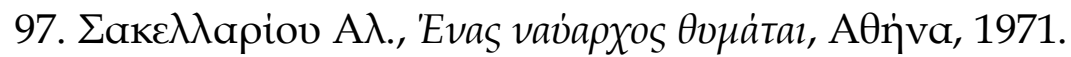

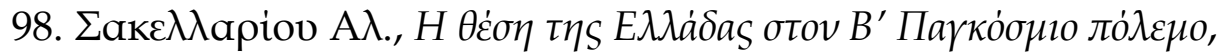
USA,1944.

99. Sayre Lucy, Freedom in Exile: A Handbook of the Governments in Exile, London, 1943.

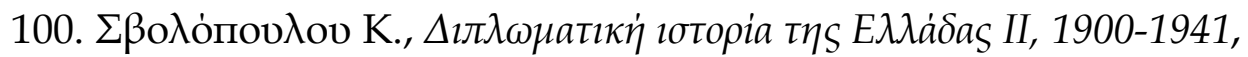

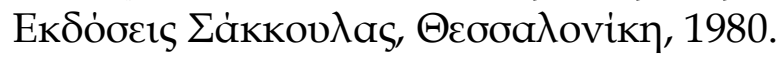

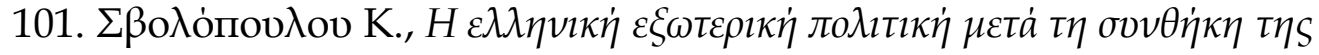

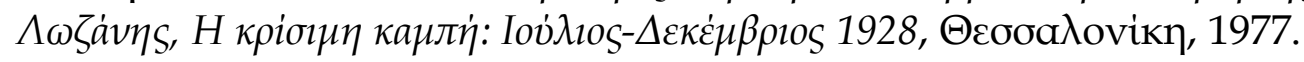

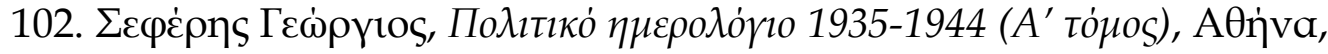
'Iкарољ, 1979.

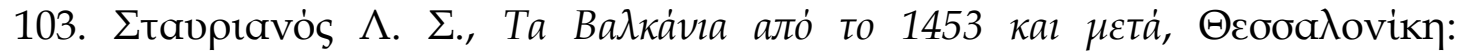

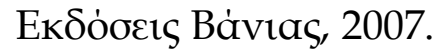

104. Stavrianos L. S., Balcan Federation, A history of the movement towards Balkan Unity in modern times, Hamden, Archon Books, 1964.

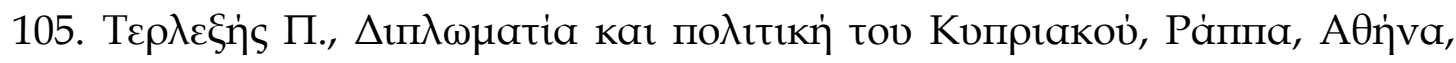
1971.

106. Tomasevich Jozo, War and Revolution in Yugoslavia, 1941-1945,

Occupation and Collaboration, Stanford, California, 2001.

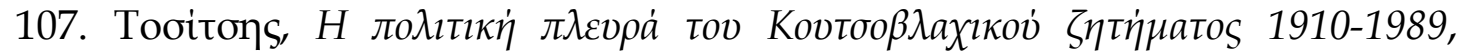
AӨท்va, 1984.

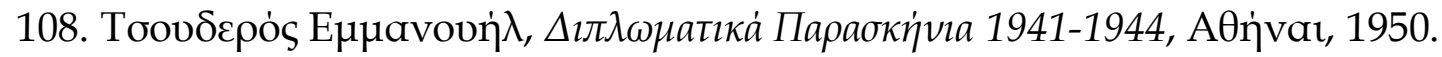

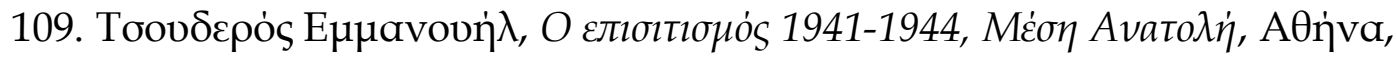
1950.

110. Ferrell Robert, American diplomacy, W. W. Norton and Co, N. York, 1975.

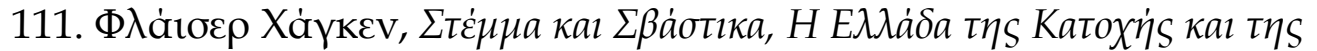

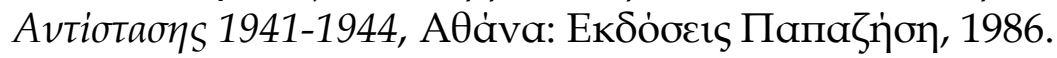




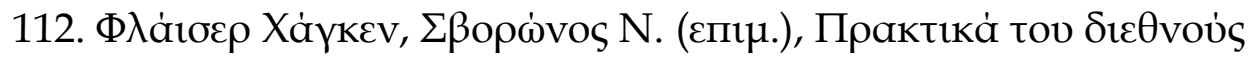

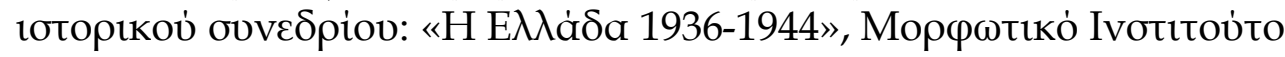
ATE, AӨn்va, 1989.

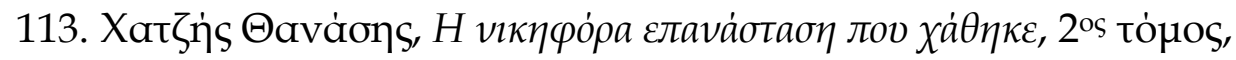
AӨท்va, 1978.

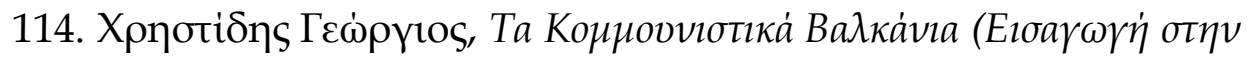

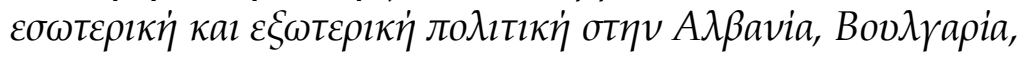

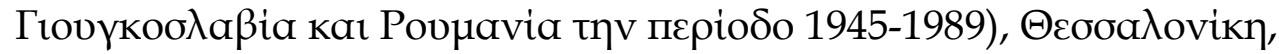
2003.

115. Xydis S., Greece and the great powers 1944-1947, Institute for Balkan Studies, Thessaloniki, 1963.

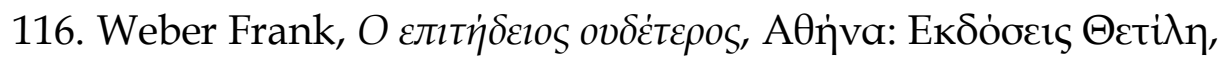
1983.

117. Weisband Edward, Turkish Foreign Policy 1943-1945: Small State Diplomacy and Great Power Politics, Princeton, 1973.

118. Wheeler Marc, Britain and the war for Yugoslavia 1940-1943, East European Monographs, Boulder, New York, 1980.

119. Winston Churchill, The Second World War. Triumph and Tragedy, Vol. 6, Boston, 1953.

120. Wittner Lawrence, American Intervention in Greece 1943-1949: A Study in Counterrevolution, Columbia University Press, New York, 1982.

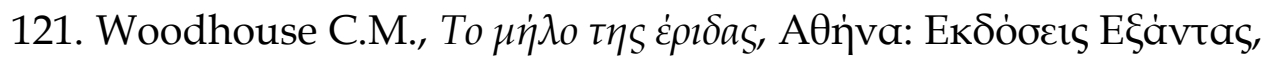
1976. 


\section{БИОГРАФИЈА АУТОРА}

Василеиос Хронопулос, име оца Николаос је рођен у Атини, Грчка, 25. априла 1981. године, где је и завршио основну и средњу школу. Студирао је Балканске студије на Аристотеловом универзитету, Солун (садашњи Универзитет Западне Македоније), где је 2004. године завршио факултет са оценом одличан (просек 8,53). Дипломски рад је, такође, одбранио са оценом 10. Наслов рада је „Словенски народи, стварање словенске азбуке и процес њеног развоја до данашњих дана (Историјски развој глагољице и ћириличног писма).“ Године 2006. уписао је на постдипломске студије историје, на Филозофском факултету, Универзитета у Београду. Студије је успешно окончао 2007. године. Завршни рад на мастер студијама је урадио под називом „Односи Влада у избеглиштву Краљевине Југославије и Краљевине Грчке, 1941 - 1944. године.“ Радио је под менторством проф. др Милана Ристовића. Године 2008. уписао је на докторске студије историје, модул - Општа савремена историја, усмерење - Савремене балканске студије. Ментор на докторским студијама је проф. др Милан Ристовић. 
Прилог 1.

Изјава о ауторству

Потписани-д Baculuoc X број уписа $2007-86 / 4 \mathrm{C}(51070086)$

Изјављујем

да је докторска дисертација под насловом

Baukatickan Moluminka Hzocicluyke Touke Buloge 1941-1944. rogutre

- резултат сопственог истраживачког рада,

- да предложена дисертација у целини ни у деловима није била предложена за добијање било које дипломе према студијским програмима других високошколских установа,

- да су резултати коректно наведени и

- да нисам кршио/ла ауторска права и користио интелектуалну својину других лица.

Потпис докторанда

у Београду, $18 / 5 / 2012$

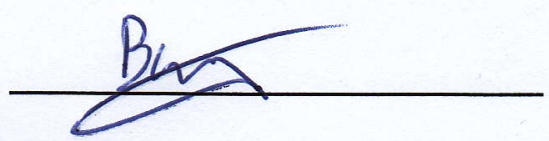




\section{Прилог 2.}

\section{Изјава о истоветности штампане и електронске верзије докторског рада}

име и презиме аутора Bacuduec Xeoнойy

Број уписа $2007-86 / 4 \mathrm{C}(51070086)$

студијски програм Hcimopujen (Aokingocke cinyguje)

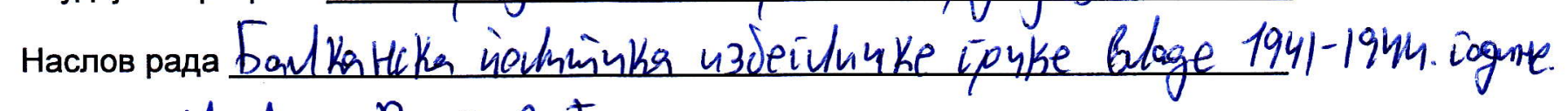
ментор Muvart Pucmiebuto

Потписани Becullud Xeortaì doc

изјављујем да је штампана верзија мог докторског рада истоветна електронској верзији коју сам предао/ла за објављивање на порталу Дигиталног репозиторијума Универзитета у Београду.

Дозвољавам да се објаве моји лични подаци везани за добијање академског звања доктора наука, као што су име и презиме, година и место рођења и датум одбране рада.

Ови лични подаци могу се објавити на мрежним страницама дигиталне библиотеке, у електронском каталогу и у публикацијама Универзитета у Београду.

Потпис докторанда

y Београду, $18 / 5 / q 012$

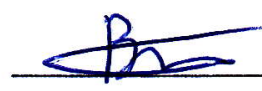




\section{Прилог 3.}

\section{Изјава о коришћењу}

Овлашћујем Универзитетску библиотеку „Светозар Марковић“ да у Дигитални репозиторијум Универзитета у Београду унесе моју докторску дисертацију под насловом:

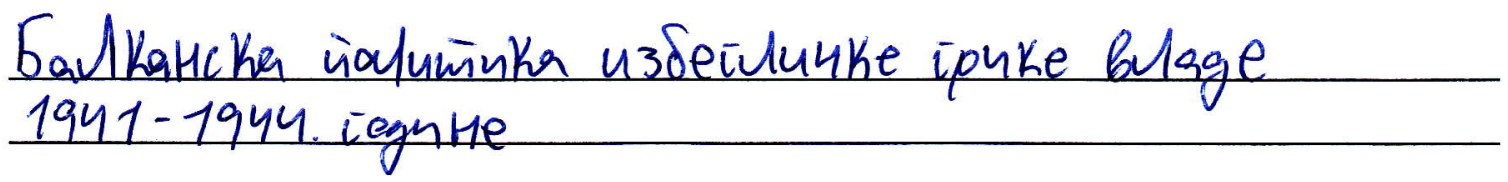
која је моје ауторско дело.

Дисертацију са свим прилозима предао/ла сам у електронском формату погодном за трајно архивирање.

Моју докторску дисертацију похрањену у Дигитални репозиторијум Универзитета у Београду могу да користе сви који поштују одредбе садржане у одабраном типу лиценце Креативне заједнице (Creative Commons) за коју сам се одлучио/ла.

\section{1. Ауторство}

2. Ауторство - некомерцијално

3. Ауторство - некомерцијално - без прераде

4. Ауторство - некомерцијално - делити под истим условима

5. Ауторство - без прераде

6. Ауторство - делити под истим условима

(Молимо да заокружите само једну од шест понуђених лиценци, кратак опис лиценци дат је на полеђини листа).

у Београду, $18 / 5 / 2012$

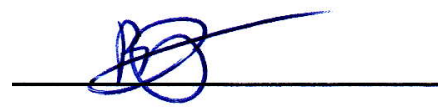

